\title{
Direct Deamination of Primary Amines via Isodiazene Intermediates
}

\section{Supporting Information}

Authors: Kathleen J. Berger ${ }^{1}$, Julia L. Driscoll ${ }^{1}$, Mingbin Yuan ${ }^{2,3}$, Balu D. Dherange ${ }^{1}$, Osvaldo Gutierrez ${ }^{2,3 *}$, Mark D. Levin ${ }^{1 *}$

${ }^{1}$ Department of Chemistry, The University of Chicago, 5735 S. Ellis Avenue, Chicago, IL 60615 USA

${ }^{2}$ Department of Chemistry, Texas A\&M University, College Station, Texas 77843, USA

${ }^{3}$ Department of Chemistry and Biochemistry, University of Maryland, College Park, Maryland 20742, USA

*Correspondence to: marklevin@uchicago.edu and og.labs@tamu.edu

\section{Table of Contents}

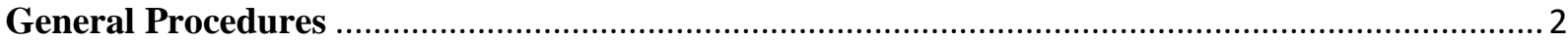

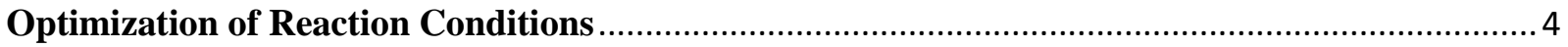

General Procedures for Preparative Scale Primary Amine Deletion......................................... 5

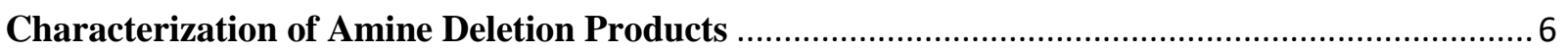

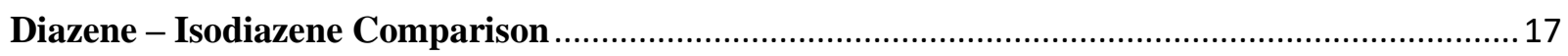

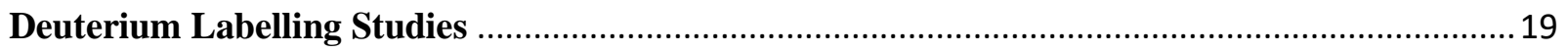

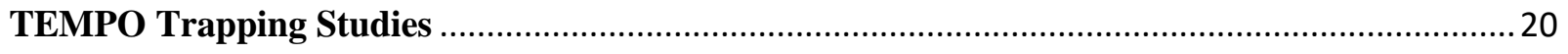

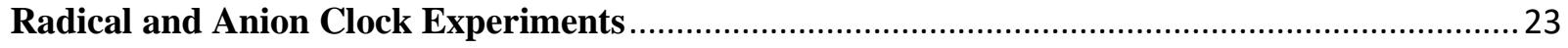

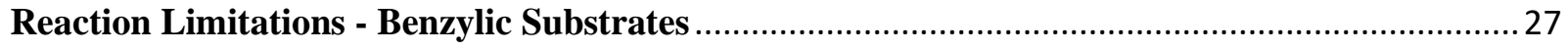

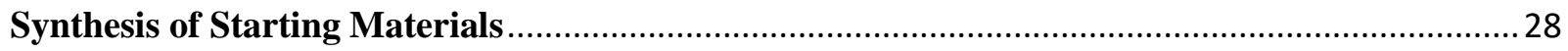

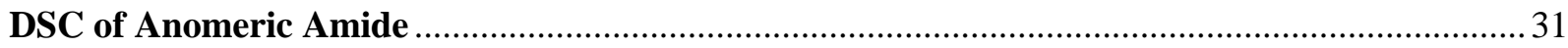

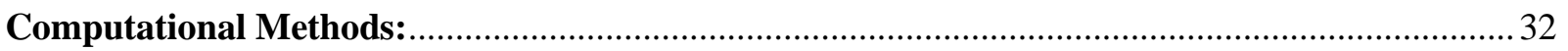

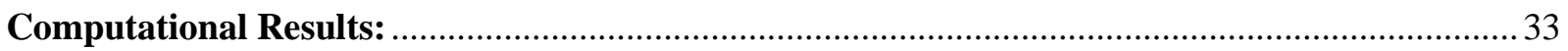

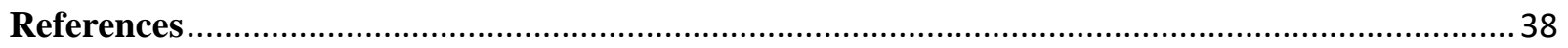

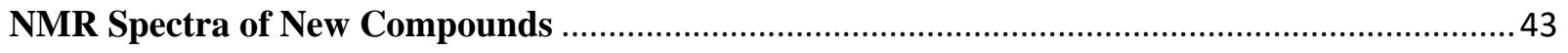

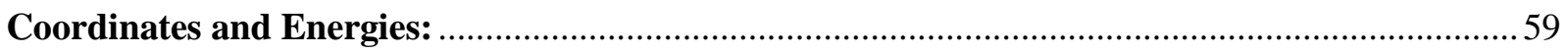




\section{General Procedures}

Unless noted otherwise, all reactions were performed in oven-dried or flame-dried glassware under an atmosphere of dry $\mathrm{N}_{2}$. THF, Et ${ }_{2} \mathrm{O}, \mathrm{DCM}$, Toluene, $\mathrm{MeCN}_{2} \mathrm{Et}_{3} \mathrm{~N}$, and Pentane were dried by passing these previously degassed solvents through a PPT Solvent Purificatiton System, and all other solvents were dried over molecular sieves (4A) and degassed prior to use or purchased anhydrous and sealed under $\mathrm{N}_{2}$ (e.g. VWR Dri-solv or equivalent). Reaction temperatures were reported as the temperatures of the bather surrounding the flasks or vials. Sensitive reagents and solvents were transferred under nitrogen into a nitrogen-filled glovebox with standard techniques. Unless otherwise noted, all reagents were used as received. Analytical thin-layer chromatography (TLC) was carried out using $0.2 \mathrm{~mm}$ commercial silica gel plates (silica gel 60, F254) and visualized by UV irradiation or staining as indicated.

Low resolution mass spectra were recorded on either an Agilent 6530 LC Q-TOF mass spectrometer using electrospray ionization with fragmentation voltage set at $115 \mathrm{~V}$ or an Agilent SQ GC-MMS with a 7890B GC using an Agilent HP-5MS column with a temperature gradient of $50{ }^{\circ} \mathrm{C}$ to $200{ }^{\circ} \mathrm{C}$ over 15 minutes and a 5977A single quad MS using electron ionization. High resolution mass spectra were recorded on either an Agilent 6224 TOF High Resolution Accurate MS with electrospray ionization or an Agilent 7200B QTOF High Resolution Accurate Mass GCMS using an Agilent HP-5MS column with a temperature gradient of $50{ }^{\circ} \mathrm{C}$ to $200{ }^{\circ} \mathrm{C}$ over 15 minutes and electron ionization. All mass spectra were processed with an Agilent MassHunter Operating System. Nuclear magnetic resonance spectra $\left({ }^{1} \mathrm{H}-\mathrm{NMR},{ }^{13} \mathrm{C}-\mathrm{NMR}\right.$ and $\left.{ }^{19} \mathrm{~F}-\mathrm{NMR}\right)$ were recorded with Bruker spectrometers operating at 400 or $500 \mathrm{MHz}$ for ${ }^{1} \mathrm{H}$. Chemical shifts are reported in parts per million (ppm, $\delta$ ), downfield from tetramethylsilane (TMS, $\delta=0.00 \mathrm{ppm}$ ) and are referenced to residual solvent $(\mathrm{CDCl} 3, \delta=7.26 \mathrm{ppm}(1 \mathrm{H})$ and $77.160 \mathrm{ppm}(13 \mathrm{C}))$. Coupling constants were reported in Hertz $(\mathrm{Hz})$. Data for ${ }^{1} \mathrm{H}-\mathrm{NMR}$ spectra were reported as follows: chemical shift (ppm, $\mathrm{s}=$ singlet, $\mathrm{d}=$ doublet, $\mathrm{t}=$ triplet, $\mathrm{q}=$ quartet, quin = quintet, $\mathrm{dd}=$ doublet of doublets, $\mathrm{td}=$ triplet of doublets, $\mathrm{ddd}=$ doublet of doublet of doublets, $\mathrm{m}=$ multiplet, coupling constant (Hz), and integration).

$N$-(benzyloxy)- $N$-(pivaloyloxy)-4-(trifluoromethyl)benzamide) (1) was prepared according to the previously reported procedure. ${ }^{1}$ 2-aminocaprolactam $\mathrm{HCl}$ was synthesized from lysine according to the literature with the exception that ethylene glycol was used as solvent. ${ }^{2}$ 7-amino-3-methyl8-oxo-5-thia-1-azabicyclo[4.2.0]oct-2-ene-2-carboxylic acid tert-butyl ester (2y) was synthesized 
from 7-aminocephalosporanic acid according to the literature. ${ }^{3}$ 4-(1,1'-biphenyl-4-yl)-3,3dimethylbutan-2-amine (2ab) was synthesized according to the literature ${ }^{4}$. 4-phenyl-but-3-yn-2ol (7) and 4-phenylbut-3-yn-2-amine (2ac) were synthesized according to the literature procedures. ${ }^{5,6}$ Leelamine (2x) was purified according to the literature procedure. ${ }^{7}$ Dimethyl 2(aminomethyl)-2-methylmalonate (2ad) was synthesized according to the literature procedure from dimethyl methyl malonate. ${ }^{8}$ 6,6-diphenylhex-5-en-1-amine (2ae) was synthesized according to the literature procedure from ethyl 6-bromohexanoate. ${ }^{9}$ Unless otherwise specified, all amines were purchased from the appropriate suppliers and used without further purification. Rimantidine $\mathrm{HCl}$, Primaquine phosphate, Oseltamivir phosphate, Sitagliptin phosphate, $\beta$ 1,3,4,6-tetra-O-acetyl-D-glucosamine $\mathrm{HCl}$, phenylalanine methyl ester $\mathrm{HCl}$ and tryptophan methyl ester $\mathrm{HCl}$ were freebased before use according to the following procedure: the amine $\mathrm{HCl}$ salt was suspended in DCM, $1 \mathrm{M} \mathrm{NaOH}$ solution was added and the amine was extracted to DCM, washed with brine, dried over sodium sulfate, filtered and the volatiles were removed in vасио. Lysine methyl ester dihydrochloride and excess cesium carbonate were suspended in acetonitrile, stirred for 4 hours and filtered with a sintered glass frit. The filtrate was collected and the solvent was removed in vacuo to yield freebase lysine methyl ester.

Safety Note: While we have not encountered any issues with routine handling of the anomeric amide reagent, we note that it does have a mildly exothermic decomposition (see DSC below). Moreover, the title reaction occurs rapidly and releases gas, so proper venting and temperature control is important especially as the scale is increased. 


\section{Optimization of Reaction Conditions}

Using the requisite solvent, to a stirred solution of anomeric amide reagent (1) under dinitrogen atmosphere was added a solution of 1-methyl-3-phenylpropylamine (2a) dropwise. The reaction was stirred at room temperature for one hour. In the initial screen, the yield of product was determined relative to the internal standard dodecane using an Agilent 6850 Network GC System with a calibration curve of authentic butylbenzene product (Table S1). The top three solvents (acetonitrile, dioxane and THF) were further analyzed by conducted three replicates of each and the yield of product was determined by NMR relative to the internal standard 1,3,5trimethoxybenzene (Table S2). Butylbenzene (3a) ${ }^{1} \mathbf{H}$ NMR $\left(400 \mathrm{MHz}, \mathrm{CDCl}_{3}\right): \delta 7.30-7.25$ $(\mathrm{m}, 2 \mathrm{H}), 7.20-7.15(\mathrm{~m}, 3 \mathrm{H}), 2.62(\mathrm{t}, \mathrm{J}=2.6 \mathrm{~Hz}, 2 \mathrm{H}), 1.65-1.56(\mathrm{~m}, 2 \mathrm{H}), 1.41-1.31(\mathrm{~m}, 2 \mathrm{H})$, $0.93(\mathrm{t}, \mathrm{J}=7.3 \mathrm{~Hz}, 3 \mathrm{H})$. Spectroscopic data are in agreement with those in the literature. ${ }^{10}$

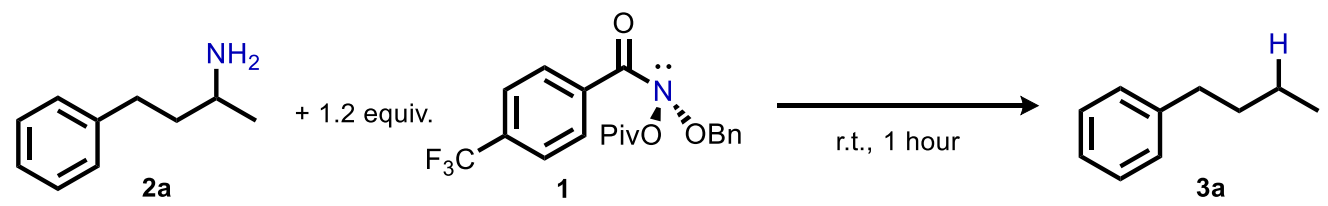

Table S1: Initial Solvent Screen Results by GC

\begin{tabular}{|l|l|}
\hline Conditions & $\begin{array}{l}\text { Yield of Product 3a } \\
(+/-5 \% \text { error from calibration curve })\end{array}$ \\
\hline THF & $74 \%$ \\
\hline Dioxane & $78 \%$ \\
\hline Ether & $46 \%$ \\
\hline DCM & $43 \%$ \\
\hline DMF & $68 \%$ \\
\hline Toluene & $1 \%$ \\
\hline ACN & $88 \%$ \\
\hline
\end{tabular}

Table S2: Additional Condition Screening Results by NMR

\begin{tabular}{|l|l|}
\hline Conditions & Yield of Product 3a \\
\hline THF & $66.8 \%+/-4.8 \%$ \\
\hline Dioxane & $71.9 \%+/-1.6 \%$ \\
\hline ACN & $\mathbf{8 8 . 0} \%+/-\mathbf{7 . 2 \%}$ \\
\hline ACN with 1 equiv. NEt 3 & $73.7 \%+/-0.2 \%$ \\
\hline ACN with cooling* & $80.6 \%+/-3.1 \%$ \\
\hline
\end{tabular}

* cooled solutions to $-15{ }^{\circ} \mathrm{C}$ before dropwise addition and then allowed reaction to warm to room temperature 


\section{General Procedures for Preparative Scale Primary Amine Deletion}

\section{General procedure A for deamination of primary aliphatic amines}

To a round bottom flask equipped with a stir bar under a nitrogen atmosphere was added the anomeric amide reagent (1.2 equiv.) and anhydrous acetonitrile. Under a nitrogen atmosphere, the primary amine ( 1 equiv.) was dissolved anhydrous acetonitrile and the solution of amine was added dropwise over 10 minutes to the flask containing the anomeric amide reagent. For select reactions, the reverse addition was performed as noted below. The total volume of solvent is such that the concentration of anomeric amide in the reaction is $0.1 \mathrm{M}$. The reaction was stirred at room temperature for 1 hour. The reaction was quenched with saturated aqueous $\mathrm{NaHCO}_{3}$ solution and extracted to DCM. The combined organic layers were washed with brine and dried with sodium sulphate. The volatiles were removed in vacuo and the crude product purified by silica gel chromatography.

\section{General procedure B for deamination of anilines}

To a 2-dram screw cap vial equipped with a stir bar and PTFE/white silicone septum was added aniline (1 equiv). The anomeric amide (1.5 equiv) and dry $\mathrm{CH}_{3} \mathrm{CN}$ was added to a second vial under nitrogen atmosphere and this solution was then transferred to the first vial containing aniline and stirred at $45{ }^{\circ} \mathrm{C}$ for 24 hours. The total volume of solvent is such that the concentration of anomeric amide in the reaction is $0.1 \mathrm{M}$. The reaction was quenched with saturated aqueous $\mathrm{NaHCO}_{3}$ solution and extracted with EtOAc. The combined organic layers were washed with brine and dried with sodium sulphate. The volatiles were removed in vacuo and the crude product purified by silica gel chromatography.

\section{Note on deviation from standard conditions and best practices}

For cyclic primary amines or amines which exhibit steric bulk due to $\beta$-branching, careful dropwise addition of the anomeric amide solution to the amine solution was found to increase the yield of the desired product. In some cases, addition over several hours using a syringe pump was most optimal. These reactions also proceed slower than unhindered $\alpha$-primary substrates, resulting in longer reaction times as noted below and should be monitored by TLC. The solvent mixture 50:50 DMSO:acetonitrile should only be used if the amine is insoluble in $100 \%$ acetonitrile. Using DMSO that was not properly dry resulted in a decreased yield of product. 


\section{Characterization of Amine Deletion Products}

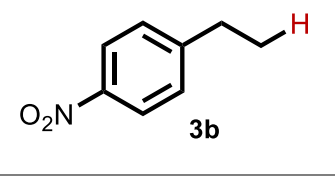

1-ethyl-4-nitrobenzene (3b): Synthesized according to general procedure A from 2-(4-nitrophenyl)ethan-1-amine (2b) (47.5 mg, $0.286 \mathrm{mmol})$. The title compound was obtained in $55 \%$ yield $(23.7 \mathrm{mg})$ after purification by silica gel chromatography. $\mathbf{R} \mathbf{f}=0.67\left(6: 4\right.$ hexanes/EtOAc). ${ }^{1} \mathbf{H}$ NMR $(400 \mathrm{MHz}, \mathrm{CDCl} 3) \delta 8.14$ $(\mathrm{d}, \mathrm{J}=8.7 \mathrm{~Hz}, 2 \mathrm{H}), 7.34$ (d, J = 8.8 Hz, 2H), $2.76(\mathrm{q}, \mathrm{J}=7.6 \mathrm{~Hz}, 2 \mathrm{H}), 1.28(\mathrm{t}, \mathrm{J}=7.6 \mathrm{~Hz}, 3 \mathrm{H})$. Spectroscopic data are in agreement with those in the literature. ${ }^{11}$

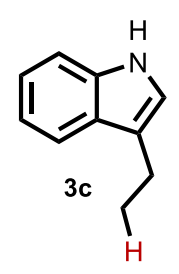

3-ethyl-1H-indole (3c): Synthesized according to general procedure A from tryptamine (2c) (56 mg, $0.365 \mathrm{mmol})$. The title compound was obtained in $65 \%$ yield (34 mg, $0.237 \mathrm{mmol})$ after purification by silica gel chromatography. $\mathbf{R}_{\mathbf{f}}=0.45(1: 1$ hexanes/EtOAc). ${ }^{1} \mathbf{H}$ NMR (400 MHz, $\mathrm{CDCl}_{3}$ ): $\delta 7.89$ (br s, $\left.1 \mathrm{H}\right), 7.62$ (d, J = $7.8 \mathrm{~Hz}$, $1 \mathrm{H}), 7.36(\mathrm{~d}, \mathrm{~J}=8.3 \mathrm{~Hz}, 1 \mathrm{H}), 7.19(\mathrm{dt}, \mathrm{J}=8.3 \mathrm{~Hz}, 1.0 \mathrm{~Hz}, 1 \mathrm{H}), 7.11(\mathrm{dt}, \mathrm{J}=7.6 \mathrm{~Hz}, 0.9 \mathrm{~Hz}, 1 \mathrm{H})$, $6.98(\mathrm{~m}, 1 \mathrm{H}), 2.80(\mathrm{qd}, \mathrm{J}=7.2 \mathrm{~Hz}, 1.1 \mathrm{~Hz}, 2 \mathrm{H}), 1.34(\mathrm{t}, \mathrm{J}=7.5 \mathrm{~Hz}, 3 \mathrm{H})$. Spectroscopic data are in agreement with those in the literature. ${ }^{12}$

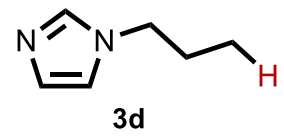

1-propyl-1H-imidazole (3d): Synthesized according to general procedure A from 3-(1H-imidazol-1-yl)propan-1-amine (2d) (146.9 mg, $1.17 \mathrm{mmol})$. The title compound was obtained in $81 \%$ yield $(105.03 \mathrm{mg})$ after purification by silica gel chromatography. $\mathbf{R}_{\mathbf{f}}=0.56$ (6:4 hexanes/EtOAc). ${ }^{1} \mathbf{H} \mathbf{~ N M R}(400 \mathrm{MHz}$, $\left.\mathrm{CD}_{3} \mathrm{CN}\right): \delta 7.43(\mathrm{~s}, 1 \mathrm{H}), 6.99(\mathrm{~d}, \mathrm{~J}=1.2 \mathrm{~Hz}, 1 \mathrm{H}), 6.90(\mathrm{~d}, \mathrm{~J}=1.1 \mathrm{~Hz}, 1 \mathrm{H}), 3.89$ (t, J = 7.1 Hz, $2 \mathrm{H}), 1.74(\mathrm{~h}, \mathrm{~J}=7.3 \mathrm{~Hz}, 2 \mathrm{H}), 0.85(\mathrm{t}, \mathrm{J}=7.4 \mathrm{~Hz}, 3 \mathrm{H})$. Spectroscopic data are in agreement with those in the literature. ${ }^{13}$

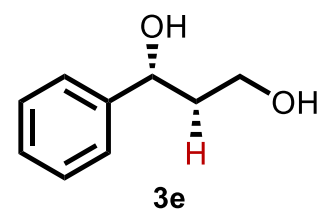

(R)-1-phenylpropane-1,3-diol (3e): Synthesized according to general procedure A from (1S,2S)-2-amino-1-phenyl-1,3-diol (2e) (35.4 mg, $0.212 \mathrm{mmol})$, by slow addition of the anomeric amide reagent solution to the solution of (1S,2S)-2-amino-1-phenyl-1,3-diol. The title compound was obtained in $74 \%$ yield $(24.0 \mathrm{mg})$ with full stereo-retention after purification by silica gel chromatography. $\mathbf{R}_{\mathbf{f}}=0.17$ (6:4 hexanes/EtOAc). ${ }^{1} \mathbf{H} \mathbf{~ N M R}(400 \mathrm{MHz}, 1: 1 \mathrm{MeOD} / \mathrm{CDCl} 3) \delta$ 
$7.35-7.26(\mathrm{~m}, 4 \mathrm{H}), 7.24-7.17(\mathrm{~m}, 1 \mathrm{H}), 4.81(\mathrm{dd}, \mathrm{J}=8.4,4.8 \mathrm{~Hz}, 1 \mathrm{H}), 3.75-3.60(\mathrm{~m}, 2 \mathrm{H})$, $2.01-1.83(\mathrm{~m}, 2 \mathrm{H})$. Spectroscopic data are in agreement with those in the literature. ${ }^{14}$

A racemic sample of 1-phenylpropane-1,3-diol was synthesized according to the literature procedure from ethyl benzoyl acetate. ${ }^{15}$ Both the enantiopure and racemic diol samples were then converted to 2,2-dimethyl-4-phenyl-1,3-dioxane by treatment with camphorsulfonic acid (10 mol\%) in 2,2-dimethoxypropane ( $50 \mu \mathrm{L} / \mathrm{mg}$ ) for $20 \mathrm{~h}$ at room temperature. The enantiomeric excess of the chiral sample was then determined to be 99 using a chiral Agilent 6850 Network GC System with an Agilent J\&W cycloSil-B GC 30 m, 0.25 mm, $0.25 \mu \mathrm{m}, 7$ inch cage column.

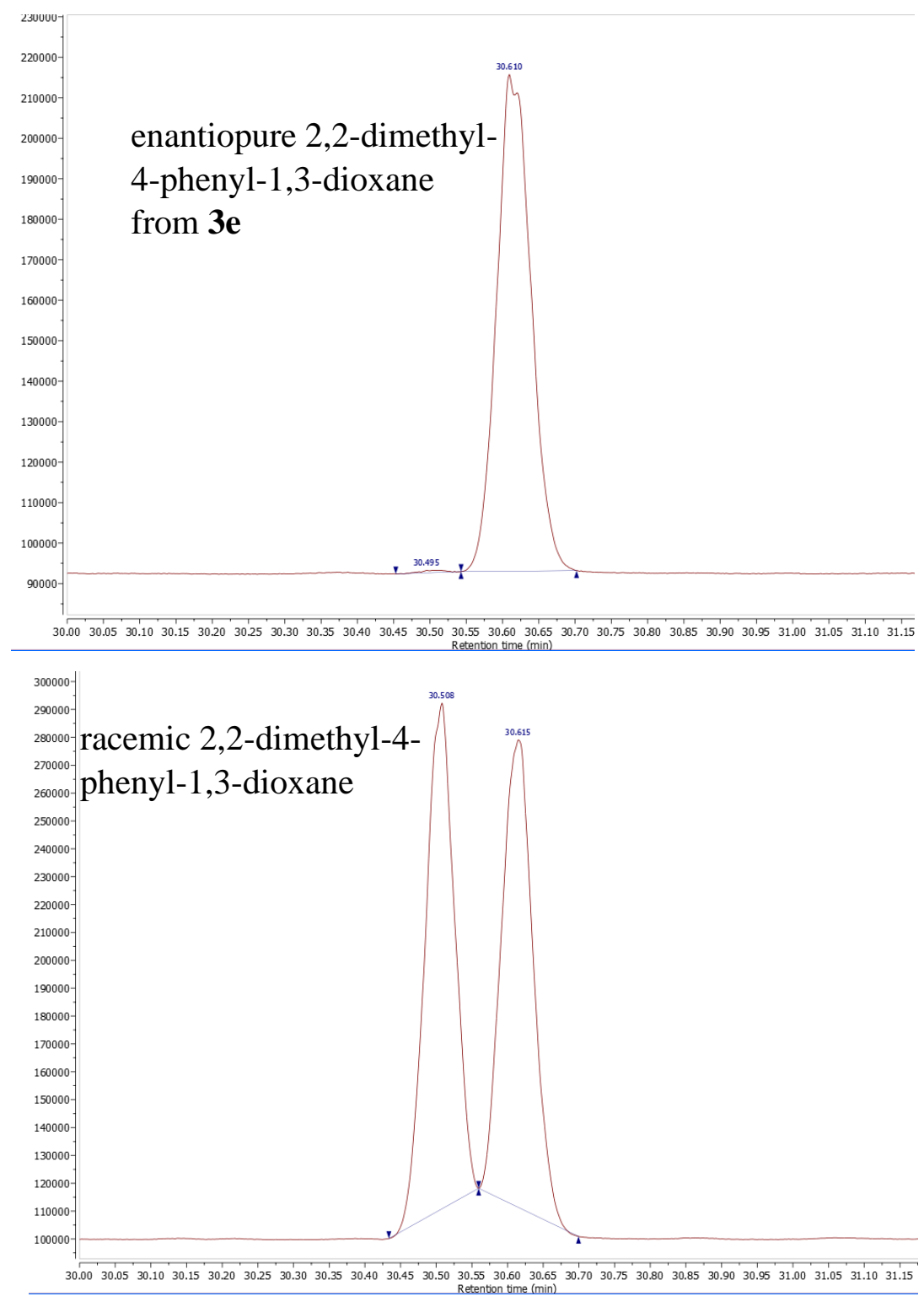




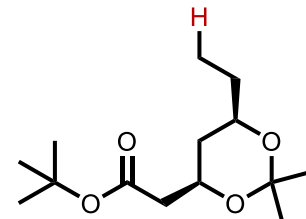

$3 f$

tert-butyl 2-((4R,6R)-6-ethyl-2,2-dimethyl-1,3-dioxan-4-yl)acetate (3f):

Synthesized according to general procedure A from (4R,6R)-tert-Butyl-6-(2-

aminoethyl)-2,2-dimethyl-1,3-dioxane-4-acetate (2f) (200 mg, $0.732 \mathrm{mmol}$ ). As separating the title compound from benzyl 4-(trifluoromethyl)benzoate is difficult by column chromatography, saponification of benzyl 4-(trifluoromethyl)benzoate to sodium 4-trifluoromethylbenzoate was performed. After the standard workup, the crude product mixture was dissolved in $9 \mathrm{ml}$ of $3: 1 \mathrm{THF}: \mathrm{H}_{2} \mathrm{O}$ in a round bottom flask equipped with a stir bar. $\mathrm{NaOH}(0.8$ equiv., $23.4 \mathrm{mg}, 0.59 \mathrm{mmol})$ was added and the solution was refluxed for 3 hours. The solvent was removed in vacuo and $10 \mathrm{ml}$ diethyl ether was added to the residue, resulting in a dark yellow precipitate. The precipitate was removed by filtration, the filtrate containing the title compound was collected and the solvent was removed in vacuo. The crude residue was purified by silica gel chromatography, yielding the title compound in $63 \%$ yield (189 $\mathrm{mg}, 0.461$ mmol). $\mathbf{R}_{\mathbf{f}}=0.81\left(5: 1\right.$ hexanes/EtOAc). ${ }^{1} \mathbf{H} \mathbf{N M R}\left(400 \mathrm{MHz}, \mathrm{CDCl}_{3}\right): \delta 4.27-4.20(\mathrm{~m}, 1 \mathrm{H})$, $3.78-3.72(\mathrm{~m}, 1 \mathrm{H}), 2.46-2.26(\mathrm{~m}, 2 \mathrm{H}), 1.57(\mathrm{dt}, \mathrm{J}=11.9 \mathrm{~Hz}, 3.1 \mathrm{~Hz}, 1 \mathrm{H}), 1.55-1.48(\mathrm{~m}, 1 \mathrm{H})$, $1.45(\mathrm{~s}, 12 \mathrm{H}), 1.38(\mathrm{~s}, 3 \mathrm{H}), 1.14(\mathrm{q}, \mathrm{J}=12.2 \mathrm{~Hz}, 2 \mathrm{H}), 0.90(\mathrm{t}, \mathrm{J}=7.6 \mathrm{~Hz}, 3 \mathrm{H}) .{ }^{13} \mathrm{C}\left\{{ }^{1} \mathbf{H}\right\} \mathrm{NMR}$ $\left(101 \mathrm{MHz} \mathrm{CDCl}_{3}\right): \delta 170.4,98.6,80.6,70.2,66.3,42.8,36.0,30.2,29.7,29.2,28.1,19.8,9.3$. HRMS (ESI) calculated 258.1831 for $\mathrm{C}_{14} \mathrm{H}_{26} \mathrm{O}_{4}$, found 258.1827.

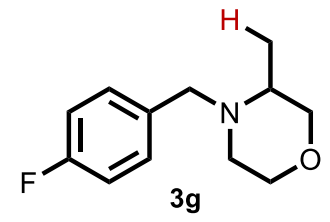

\section{4-[(4-fluorophenyl)methyl]-3-methylmorpholine (3g): Synthesized} according to general procedure A from 3-aminomethyl-4-(4fluorobenzyl)morpholine (2g) (100 mg, $0.446 \mathrm{mmol})$. The title compound was obtained in $94 \%$ yield ( $88 \mathrm{mg}$ ) after purification by silica gel chromatography. $\mathbf{R}_{\mathbf{f}}=0.42\left(5: 1\right.$ hexanes/EtOAc). ${ }^{1} \mathbf{H} \mathbf{~ N M R}\left(400 \mathrm{MHz}, \mathrm{CDCl}_{3}\right): \delta 7.32-7.27$ $(\mathrm{m}, 2 \mathrm{H}), 7.01(\mathrm{t}, \mathrm{J}=8.9 \mathrm{~Hz}, 2 \mathrm{H}), 3.87-3.81(\mathrm{~m}, 1 \mathrm{H}), 3.73-3.60(\mathrm{~m}, 2 \mathrm{H}), 3.51-3.44(\mathrm{~m}, 2 \mathrm{H})$, $2.73-2.62(\mathrm{~m}, 2 \mathrm{H}), 2.15(\mathrm{t}, \mathrm{J}=9.4 \mathrm{~Hz}, 1 \mathrm{H}), 1.83(\mathrm{t}, \mathrm{J}=11 \mathrm{~Hz}, 1 \mathrm{H}), 1.13(\mathrm{~d}, \mathrm{~J}=6.1 \mathrm{~Hz}, 3 \mathrm{H})$. ${ }^{13} \mathbf{C}\left\{{ }^{1} \mathbf{H}\right\}$ NMR $\left(101 \mathrm{MHz}, \mathrm{CDCl}_{3}\right): \delta 162.1\left(\mathrm{~d},{ }^{1} \mathrm{~J}_{\mathrm{C}-\mathrm{F}}=246 \mathrm{~Hz}\right), 130.7\left(\mathrm{~d},{ }^{3} \mathrm{~J}_{\mathrm{C}-\mathrm{F}}=8 \mathrm{~Hz}\right), 115.1(\mathrm{~d}$, $\left.{ }^{2} \mathrm{~J}_{\mathrm{C}-\mathrm{F}}=21 \mathrm{~Hz}\right), 71.8,66.7,62.4,59.9,52.8,19.1 .{ }^{19} \mathbf{F}\left\{{ }^{1} \mathbf{H}\right\} \mathrm{NMR}\left(376 \mathrm{MHz}, \mathrm{CDCl}_{3}\right): \delta-115.7$. HRMS (ESI) calculated 209.1216 for $\mathrm{C}_{12} \mathrm{H}_{16} \mathrm{FNO}$, found 209.1215. 


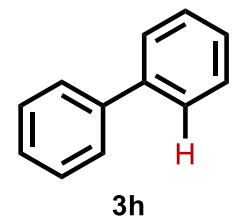

Biphenyl (3h): Synthesized according to general procedure B from 2aminobiphenyl (2h) $(50 \mathrm{mg}, 0.29 \mathrm{mmol})$. The title compound was obtained in $61 \%$ yield ( $28 \mathrm{mg}, 0.18 \mathrm{mmol}$ ) after purification by silica gel chromatography $\mathbf{R}_{\mathbf{f}}=0.7$ (24:1 hexanes/EtOAc). ${ }^{1} \mathbf{H}$ NMR (400 MHz, $\left.\mathrm{CDCl}_{3}\right) \delta 7.65-7.56(\mathrm{~m}, 4 \mathrm{H}), 7.50$ $7.41(\mathrm{~m}, 4 \mathrm{H}), 7.40-7.33(\mathrm{~m}, 2 \mathrm{H})$. Spectroscopic data are in agreement with those in the literature. ${ }^{16}$

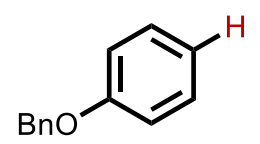

$3 \mathbf{i}$

(Benzyloxy)benzene (3i): Synthesized according to general procedure B from 4benzyloxy aniline (2i) $(40 \mathrm{mg}, 0.2 \mathrm{mmol})$ with the exception that the reaction was performed at room temperature instead of $45^{\circ} \mathrm{C}$. The title compound was obtained in $53 \%$ yield ( $19.6 \mathrm{mg}, 0.11 \mathrm{mmol})$ after purification by silica gel chromatography $\mathbf{R}_{\mathbf{f}}=0.5$ (24:1 hexanes/EtOAc). ${ }^{1} \mathbf{H}$ NMR (400 MHz, $\left.\mathrm{CDCl}_{3}\right) \delta 7.49$ - 7.43 (m, 2H), 7.43 - 7.37 (m, 2H), 7.37 $7.28(\mathrm{~m}, 3 \mathrm{H}), 7.05-6.94(\mathrm{~m}, 3 \mathrm{H}), 5.08(\mathrm{~s}, 2 \mathrm{H})$. Spectroscopic data are in agreement with those in the literature. ${ }^{17}$

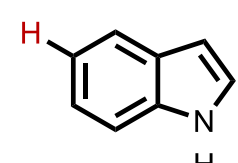

3j

Indole (3j): Synthesized according to general procedure B from 5-aminoindole (2j) (50 mg, $0.38 \mathrm{mmol}$ ). The title compound was obtained in $72 \%$ yield (32 mg, 0.27 ${ }^{H}$ mmol) after purification by silica gel chromatography $\mathbf{R}_{\mathbf{f}}=0.4$ (9:1 hexanes/EtOAc). ${ }^{1} \mathbf{H}$ NMR $\left(400 \mathrm{MHz}, \mathrm{CDCl}_{3}\right) \delta 8.01$ (br. S, $\left.1 \mathrm{H}\right), 7.68$ (dq, $\left.J=7.8,0.9 \mathrm{~Hz}, 1 \mathrm{H}\right), 7.41$ (dq, $J=8.1$, $1.0 \mathrm{~Hz}, 1 \mathrm{H}$ ), $7.25-7.19$ (m, 2H), 7.15 (ddd, $J=8.0,7.1,1.1 \mathrm{~Hz}, 1 \mathrm{H}$ ), 6.58 (ddd, $J=3.2,2.1,1.0$ $\mathrm{Hz}, 1 \mathrm{H})$. Spectroscopic data are in agreement with those in the literature. ${ }^{18}$

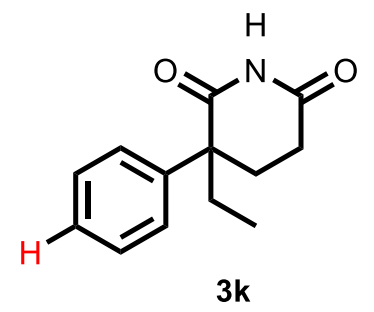

$3 \mathbf{k}$

3-ethyl-3-phenylpiperidine-2,6-dione (3k): Synthesized according to general procedure B from aminoglutetimide (2k) $(60 \mathrm{mg}, 0.26 \mathrm{mmol})$. The title compound was obtained in $64 \%$ yield $(36 \mathrm{mg}, 0.17 \mathrm{mmol}$ ) after purification by silica gel chromatography $\mathbf{R}_{\mathbf{f}}=0.5$ (3:2 hexanes/EtOAc). ${ }^{1} \mathbf{H}$ NMR (400 MHz, $\left.\mathrm{CDCl}_{3}\right) \delta 8.37-7.90(\mathrm{~m}, 1 \mathrm{H}), 7.42-7.33(\mathrm{~m}, 2 \mathrm{H}), 7.29$ (tt, $J=8.3,1.3 \mathrm{~Hz}, 3 \mathrm{H}), 2.68-2.54(\mathrm{~m}, 1 \mathrm{H}), 2.47-2.34(\mathrm{~m}, 2 \mathrm{H}), 2.23(\mathrm{td}, J=14.0,4.4 \mathrm{~Hz}, 1 \mathrm{H})$, $2.07(\mathrm{dq}, J=14.8,7.4 \mathrm{~Hz}, 1 \mathrm{H}), 1.92(\mathrm{dq}, J=14.6,7.4 \mathrm{~Hz}, 1 \mathrm{H}), 0.88(\mathrm{t}, J=7.4 \mathrm{~Hz}, 3 \mathrm{H}) .{ }^{13} \mathbf{C}\left\{{ }^{1} \mathbf{H}\right\}$ NMR $\left(101 \mathrm{MHz}, \mathrm{CDCl}_{3}\right) \delta 175.3,172.5,138.9,129.2,127.7,126.3,51.3,33.0,29.4,27.2,9.2$. HRMS (ESI) calculated 218.1176 for $\mathrm{C}_{13} \mathrm{H}_{16} \mathrm{NO}_{2}(\mathrm{M}+\mathrm{H})$, found 218.1172 . 


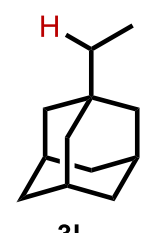

31

1-ethyladamantane (31): Synthesized according to general procedure A from rimantadine (2I) (103 $\mathrm{mg}, 0.574 \mathrm{mmol})$. The title compound was obtained in 50\% yield ( $47 \mathrm{mg}, 0.287 \mathrm{mmol}$ ) after purification by silica gel chromatography. $\mathbf{R} \mathbf{f}=0.8$ (5:1 hexanes/EtOAc). ${ }^{1} \mathbf{H}$ NMR (400 MHz, $\left.\mathrm{CDCl}_{3}\right): \delta 1.94$ (br s, 3H), $1.73-1.57$ (m, $6 \mathrm{H}), 1.44(\mathrm{~m}, 6 \mathrm{H}), 1.08(\mathrm{q}, \mathrm{J}=9.0 \mathrm{~Hz}, 2 \mathrm{H}), 0.77(\mathrm{t}, \mathrm{J}=8.3 \mathrm{~Hz}, 3 \mathrm{H})$. Spectroscopic data are in agreement with those in the literature. ${ }^{19}$

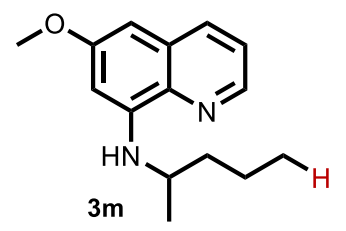

6-methoxy- $N$-(pentan-2-yl)quinolin-8-amine (3m): Synthesized according to general procedure A from primaquine (2m) (100 mg, 0.386 $\mathrm{mmol})$. The title compound was obtained in $53 \%$ yield $(49.8 \mathrm{mg}, 0.205$ mmol) after purification by silica gel chromatography $\mathbf{R}_{\mathbf{f}}=0.58$ (5:1 hexanes/EtOAc). ${ }^{1} \mathbf{H}$ NMR (400 MHz, $\left.\mathrm{CDCl}_{3}\right): \delta 8.53$ (dd, J = 4.1 Hz, $\left.1.6 \mathrm{~Hz}, 1 \mathrm{H}\right), 7.92$ (dd, J = $8.33,1 \mathrm{H}), 7.32-7.28(\mathrm{~m}, 1 \mathrm{H}), 6.33-6.28(\mathrm{~m}, 2 \mathrm{H}), 6.02$ (br m, 1H), 3.89 (s, 3H), $3.65-3.57$ (m, 1H), $1.76-1.67(\mathrm{~m}, 1 \mathrm{H}), 1.61-1.39(\mathrm{~m}, 2 \mathrm{H}), 1.29(\mathrm{~d}, \mathrm{~J}=6.2 \mathrm{~Hz}, 3 \mathrm{H}), 0.94(\mathrm{t}, \mathrm{J}=7.2 \mathrm{~Hz}$, 3H). ${ }^{13} \mathbf{C}\left\{{ }^{1} \mathbf{H}\right\}$ NMR $\left(101 \mathrm{MHz}, \mathrm{CDCl}_{3}\right): \delta$ 159.6, 145.3, 144.4, 135.6, 134.9, 130.0, 121.9, 96.6, 91.5, 55.3, 48.0, 39.2, 20.6, 19.6, 14.3. HRMS (ESI) calculated 244.1576 for $\mathrm{C}_{15} \mathrm{H}_{20} \mathrm{~N}_{2} \mathrm{O}$, found 244.1594.

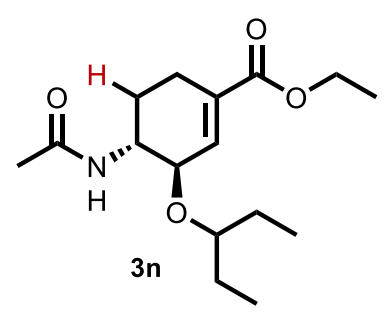

ethyl $(3 R, 4 R)$-4-acetamido-3-(pentan-3-yloxy)cyclohex-1-ene-1carboxylate (3n): Synthesized according to general procedure A from oseltamivir (2n) (88 mg, $0.282 \mathrm{mmol}$ ) with the exception of a reaction time of 5 hours. The solution of anomeric amide was added dropwise to the solution of oseltamivir and the reaction was stirred at r.t. for 5 hours. The title compound was obtained in $53 \%$ yield $(44 \mathrm{mg}, 0.149 \mathrm{mmol})$ after purification by silica gel chromatography. $\mathbf{R}_{\mathbf{f}}=0.56\left(1: 2\right.$ hexanes/EtOAc). ${ }^{1} \mathbf{H} \mathbf{N M R}\left(400 \mathrm{MHz}, \mathrm{CDCl}_{3}\right): \delta 6.84-$ $6.81(\mathrm{~m}, 1 \mathrm{H}), 5.41(\mathrm{~d}, \mathrm{~J}=8.1 \mathrm{~Hz}, 1 \mathrm{H}), 4.20(\mathrm{q}, \mathrm{J}=7.6 \mathrm{~Hz}, 2 \mathrm{H}), 4.11-4.05(\mathrm{~m}, 1 \mathrm{H}), 3.88-3.84$ (m, 1H), $3.45(\mathrm{q}, \mathrm{J}=6.2 \mathrm{~Hz}, 1 \mathrm{H}), 2.53-2.43(\mathrm{~m}, 1 \mathrm{H}), 2.27-2.16(\mathrm{~m}, 1 \mathrm{H}), 2.09-1.99(\mathrm{~m}, 1 \mathrm{H})$, $1.96(\mathrm{~s}, 3 \mathrm{H}), 1.81-1.72(\mathrm{~m}, 1 \mathrm{H}), 1.58-1.46(\mathrm{~m}, 4 \mathrm{H}), 1.29$ (t, J = $7.4 \mathrm{~Hz}, 3 \mathrm{H}), 0.91$ (q, J = 7.4 $\mathrm{Hz}, 6 \mathrm{H}) .{ }^{13} \mathbf{C}\left\{{ }^{1} \mathbf{H}\right\}\left(101 \mathrm{MHz}, \mathrm{CDCl}_{3}\right): \delta 170.0,166.9,135.8,132.8,81.7,72.6,60.9,47.8,26.7$, 
26.6, 23.7, 23.2, 21.3, 14.3, 10.1, 9.5. HRMS (ESI) calculated 297.1940 for $\mathrm{C}_{16} \mathrm{H}_{27} \mathrm{NO}_{4}$, found 297.1923.

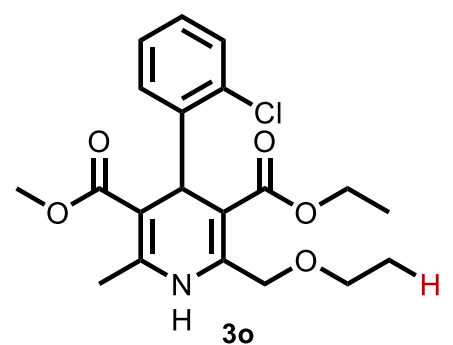

3-ethyl 5-methyl 4-(2-chlorophenyl)-2-(ethoxymethyl)-6-methyl1,4-dihydropyridine-3,5-dicarboxylate (3o): Synthesized according to general procedure A from amlodipine (2o) $(100 \mathrm{mg}$, $0.245 \mathrm{mmol})$. The title compound was obtained in $71 \%$ yield (69 $\mathrm{mg}, 0.174 \mathrm{mmol}$ ) after purification by silica gel chromatography. $\mathbf{R}_{\mathbf{f}}$ $=0.21\left(1: 1\right.$ hexanes/EtOAc). ${ }^{1} \mathbf{H} \mathbf{~ N M R}\left(400 \mathrm{MHz}, \mathrm{CDCl}_{3}\right): \delta 7.37(\mathrm{dd}, \mathrm{J}=7.9 \mathrm{~Hz}, 2.0 \mathrm{~Hz}, 1 \mathrm{H})$, 7.23 (dd, J = 7.8 Hz, 1.3 Hz, 1H), 7.12 (td, J = 7.6, 1.4 Hz, 1H), 7.10 (br s, 1H), $7.06-7.01$ (m, 1H), $5.40(\mathrm{~s}, 1 \mathrm{H}), 4.69$ (q, J = 16.6 Hz, 2H), $4.05(\mathrm{qd}, \mathrm{J}=6.9 \mathrm{~Hz}, 2.4 \mathrm{~Hz}, 2 \mathrm{H}), 3.67-3.59$ (m, $5 \mathrm{H}), 2.34(\mathrm{~s}, 3 \mathrm{H}), 1.29$ (t, J = 7.0 Hz, 3H), $1.18(\mathrm{t}, \mathrm{J}=7.1 \mathrm{~Hz}, 3 \mathrm{H}) .{ }^{13} \mathbf{C}\left\{{ }^{1} \mathbf{H}\right\}\left(101 \mathrm{MHz}, \mathrm{CDCl}_{3}\right)$ : $\delta 168.1,167.2,145.9,145.6,143.8,132.3,131.4,129.4,129.2,129.1,128.8,127.3,126.9,104.0$, 101.2, 68.2, 67.4, 67.0, 59.6, 50.8, 37.1, 27.2, 19.6, 15.1, 14.3. HRMS (ESI) calculated 393.1343 for $\mathrm{C}_{20} \mathrm{H}_{24} \mathrm{ClNO}_{5}$, found 393.1321 .

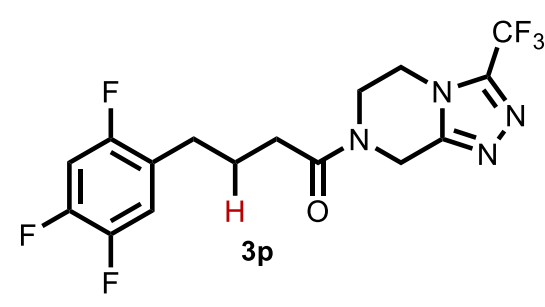

\section{1-(3-(trifluoromethyl)-5,6-dihydro-[1,2,4]triazolo[4,3-} a]pyrazin-7(8H)-yl-(4(2,4,5-trifluorophenyl)butan-1-one (3p): Synthesized according to general procedure A from sitagliptin (2p) (200 mg, $0.490 \mathrm{mmol})$. The title compound was obtained in $52 \%$ yield (100 $\mathrm{mg}, 0.255 \mathrm{mmol})$ after

purification by silica gel chromatography. $\mathbf{R}_{\mathbf{f}}=0.75\left(100 \%\right.$ EtOAc). ${ }^{1} \mathbf{H} \mathbf{N M R}(400 \mathrm{MHz}$, $\left.\mathrm{CDCl}_{3}\right): \delta 7.05-6.96(\mathrm{~m}, 1 \mathrm{H}), 6.90-6.82(\mathrm{~m}, 1 \mathrm{H}), 5.08-4.85(\mathrm{~m}, 2 \mathrm{H}), 4.25-3.87(\mathrm{~m}, 4 \mathrm{H})$, $2.66(\mathrm{t}, \mathrm{J}=7.6 \mathrm{~Hz}, 2 \mathrm{H}), 2.43(\mathrm{t}, \mathrm{J}=7.0 \mathrm{~Hz}, 2 \mathrm{H}), 2.02-1.92(\mathrm{~m}, 2 \mathrm{H}) .{ }^{13} \mathbf{C}\left\{{ }^{1} \mathrm{H}\right\}(101 \mathrm{MHz}$, $\left.\mathrm{CDCl}_{3}\right): \delta 171.3,156.1\left(\mathrm{ddd}, \mathrm{J}_{\mathrm{C}-\mathrm{F}}=241 \mathrm{~Hz}, 9 \mathrm{~Hz}, 3 \mathrm{~Hz}\right), 148.6\left(\mathrm{dt}, \mathrm{J}_{\mathrm{C}-\mathrm{F}}=248 \mathrm{~Hz}, 16 \mathrm{~Hz}\right), 146.8$ $\left(\mathrm{dd}, \mathrm{J}_{\mathrm{C}-\mathrm{F}}=245 \mathrm{~Hz}, 13 \mathrm{~Hz}\right), 145.6(\mathrm{~m}), 124.5(\mathrm{dt}, \mathrm{J}=18 \mathrm{~Hz}, 4 \mathrm{~Hz}), 118.1(\mathrm{dd}, \mathrm{J}=18 \mathrm{~Hz}, 6 \mathrm{~Hz})$, 105.6 (dd, J $=29 \mathrm{~Hz}, 21 \mathrm{~Hz}), 43.3,42.4,38.1,32.0,27.6,24.8,22.7 .{ }^{19} \mathbf{F}\left\{{ }^{1} \mathbf{H}\right\} \mathrm{NMR}(376 \mathrm{MHz}$, $\left.\mathrm{CDCl}_{3}\right): \delta-63.1,-120.4(\mathrm{~d}, \mathrm{~J}=16 \mathrm{~Hz}),-136.6(\mathrm{~d}, \mathrm{~J}=23 \mathrm{~Hz}),-143.2(\mathrm{~m})$. HRMS (ESI) calculated 383.1115, found 383.1119. 


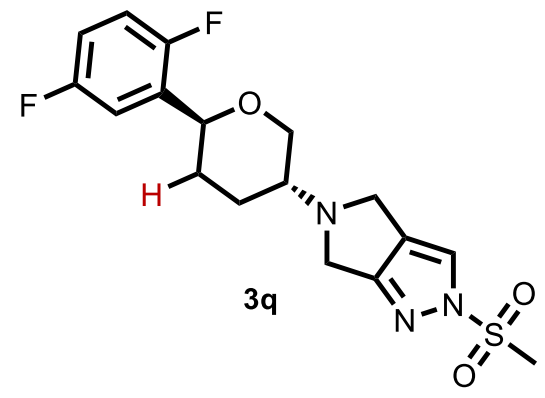

\section{5-((3R,6S)-6-(2,5-difluorophenyl)tetrahydro-2H-pyran-3-} yl)-2-(methylsulfonyl)-2,4,5,6-tetrahydropyrrolo[3,4-

c]pyrazole (3q): Synthesized according to general procedure A from omarigliptin (2q) (50 mg, $0.125 \mathrm{mmol})$. The title compound was obtained in 77\% (37 mg, $0.096 \mathrm{mmol}$ ) yield after purification by silica gel chromatography. $\mathbf{R}_{\mathbf{f}}=0.20(1: 1$ hexanes: EtOAc). ${ }^{1} \mathbf{H}$ NMR (400 MHz, $\left.\mathrm{CDCl}_{3}\right): \delta 7.69$ (s, 1H), $7.22-7.16(\mathrm{~m}, 1 \mathrm{H}), 7.00-6.87$ (m, 2H), 4.59 (d, J = 10.6 Hz, 1H), $4.32(\mathrm{dq}, \mathrm{J}=10.7 \mathrm{~Hz}, 2.4 \mathrm{~Hz}, 1 \mathrm{H}), 3.92-3.82(\mathrm{~m}, 4 \mathrm{H}), 3.48$ (t, J = 11.4 Hz, 1H), 3.27 (s, 3H), $2.91-2.82(\mathrm{~m}, 1 \mathrm{H}), 2.28-2.20(\mathrm{~m}, 1 \mathrm{H}), 2.10-2.02(\mathrm{~m}, 1 \mathrm{H})$, $1.70(\mathrm{qd}, \mathrm{J}=12.0 \mathrm{~Hz}, 3.7 \mathrm{~Hz}, 1 \mathrm{H}), 1.59$ (qd, J = $13.8 \mathrm{~Hz}, 3.7 \mathrm{~Hz}, 1 \mathrm{H}) .{ }^{19} \mathbf{F}\left\{{ }^{1} \mathbf{H}\right\} \mathrm{NMR}(376 \mathrm{MHz}$, $\left.\mathrm{CDCl}_{3}\right): \delta-118.5(\mathrm{~d}, \mathrm{~J}=17.8 \mathrm{~Hz}),-125.6(\mathrm{~d}, \mathrm{~J}=18.5 \mathrm{~Hz}) .{ }^{13} \mathbf{C}\left\{{ }^{1} \mathbf{H}\right\}\left(101 \mathrm{MHz}, \mathrm{CDCl}_{3}\right): \delta 164.2$, $159.0\left(\mathrm{dd},{ }^{1} \mathrm{~J}_{\mathrm{C}-\mathrm{F}}=242 \mathrm{~Hz},{ }^{4} \mathrm{~J}_{\mathrm{C}-\mathrm{F}}=1 \mathrm{~Hz}\right), 155.2\left(\mathrm{dd},{ }^{1} \mathrm{~J}_{\mathrm{C}-\mathrm{F}}=242 \mathrm{~Hz},{ }^{4} \mathrm{~J}_{\mathrm{C}-\mathrm{F}}=1 \mathrm{~Hz}\right), 131.4\left(\mathrm{dd},{ }^{2} \mathrm{~J}_{\mathrm{C}-\mathrm{F}}\right.$ $\left.=16 \mathrm{~Hz},{ }^{3} \mathrm{~J}_{\mathrm{C}-\mathrm{F}}=8 \mathrm{~Hz}\right), 124.4,123.5,116.2\left(\mathrm{dd},{ }^{2} \mathrm{~J}_{\mathrm{C}-\mathrm{F}}=12 \mathrm{~Hz},{ }^{3} \mathrm{~J}_{\mathrm{C}-\mathrm{F}}=8 \mathrm{~Hz}\right), 115.0\left(\mathrm{dd},{ }^{2} \mathrm{~J}_{\mathrm{C}-\mathrm{F}}=13\right.$ $\left.\mathrm{Hz},{ }^{3} \mathrm{~J}_{\mathrm{C}-\mathrm{F}}=9 \mathrm{~Hz}\right), 113.7\left(\mathrm{dd},{ }^{2} \mathrm{~J}_{\mathrm{C}-\mathrm{F}}=13 \mathrm{~Hz},{ }^{3} \mathrm{~J}_{\mathrm{C}-\mathrm{F}}=5 \mathrm{~Hz}\right), 73.2,71.7,59.3,48.7,48.2,41.5,31.7$, 29.4. HRMS (ESI) calculated 392.1072, found 392.1089.

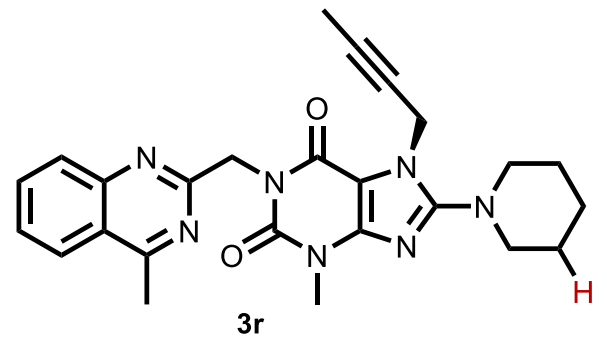

7-(but-2-yn-1-yl)-3-methyl-1-((4-methylquinazolin-2yl)methyl)-8-(piperidin-1-yl)-3,7-dihydro-1H-purine-2,6dione (3r): Synthesized according to general procedure A from linagliptin (2r) (10 $\mathrm{mg}, 0.0212 \mathrm{mmol})$ with the exception that 1:1 acetonitrile: DMSO was used as the

solvent and the reaction was stirred overnight, then washed with $3 \times 10 \mathrm{ml}$ brine to remove the DMSO. The title compound was obtained in $65 \%$ yield $(6.3 \mathrm{mg}, 0.0138 \mathrm{mmol})$ after purification by silica gel chromatography. $\mathbf{R}_{\mathbf{f}}=0.3$ (1:3 hexanes: EtOAc). ${ }^{1} \mathbf{H} \mathbf{N M R}\left(400 \mathrm{MHz}, \mathrm{CDCl}_{3}\right): \delta$ $8.01(\mathrm{~d}, \mathrm{~J}=8.1 \mathrm{~Hz}, 1 \mathrm{H}), 7.89-7.84(\mathrm{~m}, 1 \mathrm{H}), 7.78-7.73(\mathrm{td}, \mathrm{J}=7.8,1.5 \mathrm{~Hz}, 1 \mathrm{H}), 7.51$ (t, J = $7.3 \mathrm{~Hz}, 1 \mathrm{H}), 5.56(\mathrm{~s}, 2 \mathrm{H}), 4.85(\mathrm{~m}, 2 \mathrm{H}), 3.55(\mathrm{~s}, 3 \mathrm{H}), 3.40-3.35(\mathrm{~m}, 3 \mathrm{H}), 2.88(\mathrm{~s}, 3 \mathrm{H}), 1.81-$ $1.58(\mathrm{~m}, 10 \mathrm{H}) .{ }^{13} \mathbf{C}\left\{{ }^{1} \mathbf{H}\right\}\left(101 \mathrm{MHz}, \mathrm{CDCl}_{3}\right): \delta 168.5,161.2,156.9,154.4,152.0,150.0,148.2$, 133.2, 129.0, 126.7, 124.9, 123.2, 81.1, 73.3, 51.2, 46.4, 41.0, 35.9, 29.8, 27.2, 25.8, 24.2, 22.0,

21.8, 3.80. HRMS (ESI) calculated 457.2226 for $\mathrm{C}_{25} \mathrm{H}_{27} \mathrm{~N}_{7} \mathrm{O}_{2}$, found 457.2226. 


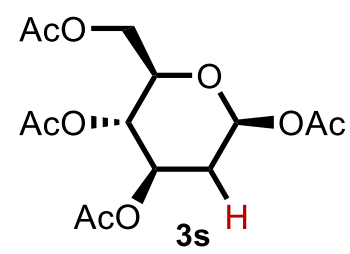

及-1,3,4,6-Tetra-O-acetyl-2-deoxy-D-glucose (3s): Synthesized according to general procedure A from $\beta-1,3,4,6$-tetra-O-acetyl-D-glucosamine (2s) (200 $\mathrm{mg}, 0.576 \mathrm{mmol}$ ) with the exception that the reaction was stirred overnight. The title compound was obtained in $78 \%$ yield (149 mg, 0.449 mmol) after purification by silica gel chromatography. $\quad \mathbf{R}_{\mathbf{f}}=0.54$ (1:1 hexanes: EtOAc). ${ }^{1} \mathbf{H}$ NMR (400 MHz, $\left.\mathrm{CDCl}_{3}\right): \delta 5.80(\mathrm{dd}, \mathrm{J}=10.1 \mathrm{~Hz}, 2.2 \mathrm{~Hz}, 1 \mathrm{H}), 5.11-5.00(\mathrm{~m}, 2 \mathrm{H}), 4.32(\mathrm{dd}, \mathrm{J}$ $=12.6 \mathrm{~Hz}, 4.7 \mathrm{~Hz}, 1 \mathrm{H}), 4.09(\mathrm{dd}, \mathrm{J}=12.3 \mathrm{~Hz}, 2.4 \mathrm{~Hz}, 1 \mathrm{H}), 3.76-3.72(\mathrm{~m}, 1 \mathrm{H}), 2.38-2.32(\mathrm{~m}$, $1 \mathrm{H}), 2.12(\mathrm{~s}, 3 \mathrm{H}), 2.09(\mathrm{~s}, 3 \mathrm{H}), 1.91-1.82(\mathrm{~m}, 1 \mathrm{H})$. Spectroscopic data are in agreement with those in the literature. ${ }^{20}$

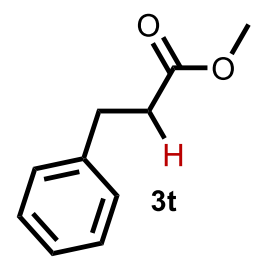

3-phenylpropanoic acid methyl ester (3t): Synthesized according to general procedure A from L-phenylalanine methyl ester (2t) $(100 \mathrm{mg}, 0.464 \mathrm{mmol})$. The title compound was obtained in $96 \%$ yield $(73 \mathrm{mg}, 0.445 \mathrm{mmol})$ after purification by silica gel chromatography. $\mathbf{R}_{\mathbf{f}}=0.57$ (5:1 hexanes/EtOAc). ${ }^{1} \mathbf{H}$ NMR (400 MHz, $\left.\mathrm{CDCl}_{3}\right): \delta 7.31-7.26(\mathrm{~m}, 2 \mathrm{H}), 7.23-7.17$ (m, 3H), 3.67 (s, 3H), 2.96 (t, J = $8.3 \mathrm{~Hz}, 2 \mathrm{H}), 2.64(\mathrm{t}, \mathrm{J}=7.0 \mathrm{~Hz}, 2 \mathrm{H})$. Spectroscopic data are in agreement with those in the literature. $^{21}$

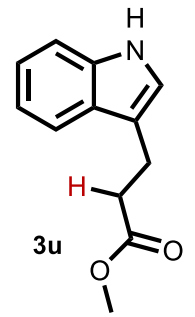

Methyl indole-3-propionate (3u): Synthesized according to general procedure A from L-tryptophan methyl ester (2u) $(100 \mathrm{mg}, 0.458 \mathrm{mmol})$. The title compound was obtained in $71 \%$ yield $(66 \mathrm{mg}, 0.325 \mathrm{mmol})$ after purification by silica gel chromatography. $\mathbf{R}_{\mathbf{f}}=0.7$ (1:5 hexanes/EtOAc). ${ }^{1} \mathbf{H} \mathbf{~ N M R}\left(400 \mathrm{MHz}, \mathrm{CDCl}_{3}\right): \delta$ 7.95 (br s, 1H), $7.61(\mathrm{~d}, \mathrm{~J}=8.0 \mathrm{~Hz}, 1 \mathrm{H}), 7.36(\mathrm{~d}, \mathrm{~J}=8.0 \mathrm{~Hz}, 1 \mathrm{H}), 7.20$ (t, J = $7.4 \mathrm{~Hz}$, $1 \mathrm{H}), 7.12(\mathrm{t}, \mathrm{J}=7.5 \mathrm{~Hz}, 1 \mathrm{H}), 7.02(\mathrm{~m}, 1 \mathrm{H}), 3.68(\mathrm{~s}, 1 \mathrm{H}), 3.11(\mathrm{t}, \mathrm{J}=8.2 \mathrm{~Hz}, 2 \mathrm{H}), 2.73(\mathrm{t}, \mathrm{J}=7.1$ $\mathrm{Hz}, 2 \mathrm{H})$. Spectroscopic data are in agreement with those in the literature. ${ }^{22}$

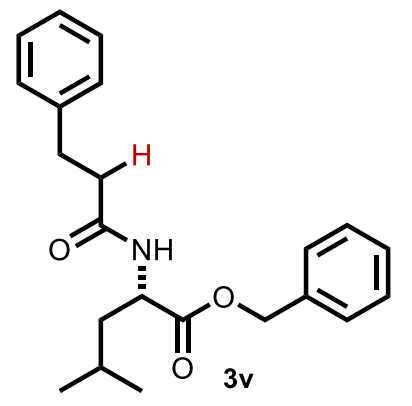

benzyl (3-phenylpropanoyl)- $L$-leucinate (3v): Synthesized according to general procedure A from H-Phe-Leu-OBzl (2v) $(207.6 \mathrm{mg}, 0.5634$ mmol) with the exception that 1:1 acetonitrile: DMSO as the solvent and the reaction was stirred for 3 hours, diluted with DCM and then washed with $3 \times 10 \mathrm{ml}$ brine. The volatiles were removed in vacuo and 
crude material was purified by reverse-phase preparative HPLC with an Agilent 5 Prep C18 P/N 446905-702 column using water/acetonitrile with the gradient 0-0.5 min, 10\% B; 0.5-10.5 min, $10-95 \% \mathrm{~B} ; 10.5-11.595 \% \mathrm{~B}$. The title compound was obtained in $21 \%$ yield $(41.8 \mathrm{mg}, 0.1183$ mmol), retention time $8.17 \mathrm{~min} . \mathbf{R}_{\mathbf{f}}=0.73$ (1:1 hexanes/EtOAc). ${ }^{1} \mathbf{H}$ NMR $\left(400 \mathrm{MHz}, \mathrm{CDCl}_{3}\right): \delta$ $7.39-7.31(\mathrm{~m}, 5 \mathrm{H}), 7.29-7.25(\mathrm{~m} 2 \mathrm{H}), 7.22$ - $7.17(\mathrm{~m}, 3 \mathrm{H}), 5.72(\mathrm{~d}, \mathrm{~J}=8.3 \mathrm{~Hz}, 1 \mathrm{H}), 5.15(\mathrm{~s}$, $2 \mathrm{H}), 4.71-4.64(\mathrm{~m}, 1 \mathrm{H}), 3.03-2.91(\mathrm{~m}, 2 \mathrm{H}), 2.59-2.46(\mathrm{~m}, 2 \mathrm{H}), 1.64-1.40(\mathrm{~m}, 3 \mathrm{H}), 0.89-$ $0.85(\mathrm{~m}, 6 \mathrm{H}) .{ }^{13} \mathbf{C}\left\{{ }^{1} \mathbf{H}\right\}\left(101 \mathrm{MHz}, \mathrm{CDCl}_{3}\right): \delta 173.1,171.9,140.8,135.5,128.8,128.7,128.6$, 128.5, 128.4, 126.4, 67.2, 50.9, 41.8, 38.4, 31.6, 24.8, 22.9, 22.1. HRMS (ESI) calculated 353.1991 for $\mathrm{C}_{22} \mathrm{H}_{27} \mathrm{NO}_{3}$, found 353.1998.

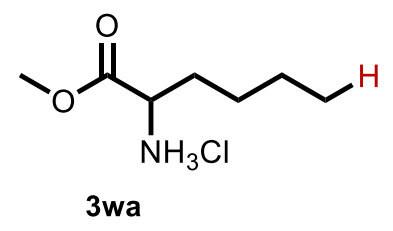

norleucine methyl ester hydrochloride (3wa): Synthesized according to general procedure A from lysine methyl ester (2w) (150 mg, 0.936 mmol) with the exception that 0.98 equivalents of anomeric amide was used. After 1 hour, 1.1 equiv. of $4 \mathrm{M} \mathrm{HCl}$ in dioxane solution $(230 \mu \mathrm{l})$ was added dropwise by syringe to the crude reaction mixture. $50 \mathrm{ml}$ of diethyl ether was added and the reaction was extracted with $5 \times 50 \mathrm{ml}$ water. Water was removed by vacuum and the residue was dissolved in DCM, dried over sodium sulphate, filtered and the volatiles were removed in vacuo to give the title compound in $69 \%$ yield $(117 \mathrm{mg}, 0.65 \mathrm{mmol}) .{ }^{\mathbf{1}} \mathbf{H}$ NMR (400 MHz, DMSO): $\delta 8.47$ (br s, 3H), 4.03 - 3.97 (m, 1H), 3.75 (s, 3H), 1.83 - 1.74 (m, 2H), 1.40 $1.21(\mathrm{~m}, 4 \mathrm{H}), 0.87(\mathrm{t}, \mathrm{J}=7.2 \mathrm{~Hz}, 3 \mathrm{H})$. Spectroscopic data are in agreement with those in the literature. $^{23}$

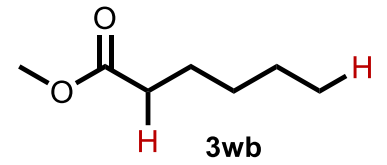

methyl hexanoate $(\mathbf{3 w b})$ : Synthesized according to general procedure A from lysine methyl ester (2wb) (20 $\mathrm{mg}, 0.125 \mathrm{mmol})$ with the exception

that 2.1 equivalents of anomeric amide were used. After 1 hour, internal standard 1,3,5trimethoxybenzene $(6.4 \mathrm{mg}, 0.038 \mathrm{mmol})$ was added and the volatiles were removed in vacuo and the residue was dissolved in $\mathrm{CDCl}_{3}$ and the NMR yield of the title compound was determined to be 54\%. ${ }^{1} \mathbf{H} \mathbf{~ N M R}\left(400 \mathrm{MHz} \mathrm{CDCl}_{3}\right): \delta 3.66(\mathrm{~s}, 3 \mathrm{H}), 2.30(\mathrm{t}, \mathrm{J}=7.6 \mathrm{~Hz}, 2 \mathrm{H})$, 
$1.68-1.59(\mathrm{~m}, 2 \mathrm{H}), 1.33-1.27(\mathrm{~m}, 4 \mathrm{H}), 0.90(\mathrm{t}, \mathrm{J}=7.2 \mathrm{~Hz}, 3 \mathrm{H})$. Spectroscopic data are in agreement with those in the literature. ${ }^{24}$

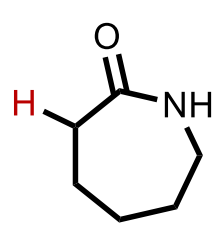

3wc

caprolactam (3wc): A $20 \mathrm{ml}$ vial equipped with a stir bar was charged with 2aminocaprolactam $\mathrm{HCl}(20 \mathrm{mg}, 0.121 \mathrm{mmol}), 2 \mathrm{ml}$ acetonitrile and cesium carbonate (79 mg, $0.242 \mathrm{mmol}, 2$ equiv.). Under a nitrogen atmosphere, a $1 \mathrm{ml}$ solution of the anomeric amide reagent ( $58 \mathrm{mg}, 0.146 \mathrm{mmol}, 1.2$ equiv.) was added dropwise and the reaction was subsequently stirred overnight. The crude reaction mixture was purified by silica gel chromatography and the title compound was obtained in $58 \%$ yield $(8$ $\mathrm{mg}, 0.07 \mathrm{mmol})$. $\mathbf{R}_{\mathbf{f}}=0.13$ (1:3 hexanes: EtOAc). ${ }^{1} \mathbf{H} \mathbf{~ N M R}\left(400 \mathrm{MHz}, \mathrm{CDCl}_{3}\right): \delta 6.29$ (br s), $3.19(\mathrm{q}, \mathrm{J}=5.9 \mathrm{~Hz}, 2 \mathrm{H}), 2.47-2.42(\mathrm{~m}, 2 \mathrm{H}), 1.78-1.60(\mathrm{~m}, 6 \mathrm{H})$. Spectroscopic data are in agreement with those in the literature. ${ }^{25}$

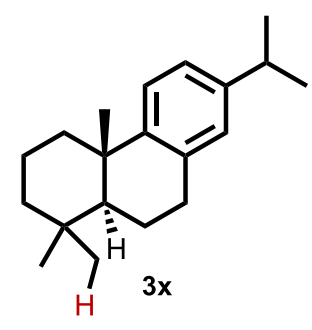

abietatriene (3x): Synthesized according to general procedure A from leelamine (2x) (100 mg, $0.350 \mathrm{mmol})$ with the exception that the solution of anomeric amide was added to the solution of leelamine by careful dropwise addition. The title compound was obtained in $65 \%$ yield $(62 \mathrm{mg}, 0.228$ mmol) after purification by silica gel chromatography. $\mathbf{R}_{\mathbf{f}}=0.65(100 \%$ hexanes). ${ }^{1} \mathbf{H}$ NMR (400 MHz, $\left.\mathrm{CDCl}_{3}\right): \delta 7.20-7.16(\mathrm{~m}, 1 \mathrm{H}), 6.99(\mathrm{dd}, \mathrm{J}=8.4 \mathrm{~Hz}, 1.5 \mathrm{~Hz})$, $6.89(\mathrm{~m}, 1 \mathrm{H}), 2.96-2.78(\mathrm{~m}, 3 \mathrm{H}), 2.27(\mathrm{~d}, \mathrm{~J}=13.0 \mathrm{~Hz}, 1 \mathrm{H}), 1.91-1.32(\mathrm{~m}, 8 \mathrm{H}), 1.23(\mathrm{~d}, \mathrm{~J}=$ $7.2 \mathrm{~Hz}, 3 \mathrm{H}), 1.18(\mathrm{~s}, 3 \mathrm{H}), 0.95(\mathrm{~s}, 3 \mathrm{H}), 0.93(\mathrm{~s}, 3 \mathrm{H})$. Spectroscopic data are in agreement with those in the literature. ${ }^{26}$

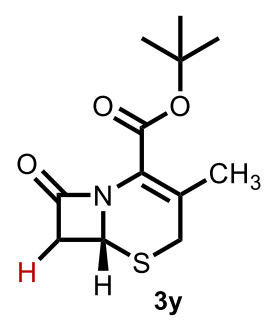

tert-butyl-3-methyl-8-oxo-5-thia-1-azabicyclo[4.2.0]oct-2-ene-2-carboxylate (3y): Synthesized according to general procedure A from 7-amino-3-methyl-8oxo-5-thia-1-azabicyclo[4.2.0]oct-2-ene-2-carboxylic acid tert-butyl ester (2y) ( $40 \mathrm{mg}, 0.187 \mathrm{mmol}$ ) with the exception that the reaction was stirred overnight. The title compound was obtained in $43 \%$ yield (19.8 mg, $0.078 \mathrm{mmol}$ ) after purification by silica gel chromatography. $\mathbf{R}_{\mathbf{f}}=0.21\left(5: 1\right.$ hexanes/EtOAc). ${ }^{1} \mathbf{H} \mathbf{N M R}(400$ 
$\left.\mathrm{MHz}, \mathrm{CDCl}_{3}\right): \delta 4.65-4.63(\mathrm{dd}, \mathrm{J}=5.1 \mathrm{~Hz}, 2.3 \mathrm{~Hz}, 1 \mathrm{H}), 3.57-3.48(\mathrm{~m}, 2 \mathrm{H}), 3.14(\mathrm{~d}, \mathrm{~J}=18.0$ $\mathrm{Hz}, 1 \mathrm{H}), 2.90(\mathrm{dd}, \mathrm{J}=15.6 \mathrm{~Hz}, 2.2 \mathrm{~Hz}, 1 \mathrm{H}), 2.05(\mathrm{~s}, 3 \mathrm{H}), 1.55(\mathrm{~s}, 9 \mathrm{H}) .{ }^{13} \mathbf{C}\left\{{ }^{1} \mathbf{H}\right\}(101 \mathrm{MHz}$, $\left.\mathrm{CDCl}_{3}\right): \delta 162.3,161.3,125.3,124.3,82.7,48.7,44.5,31.5,28.0,19.5,1.0$. HRMS (ESI) calculated 255.0929 for $\mathrm{C}_{12} \mathrm{H}_{17} \mathrm{NO}_{3} \mathrm{~S}$, found 255.0928 .

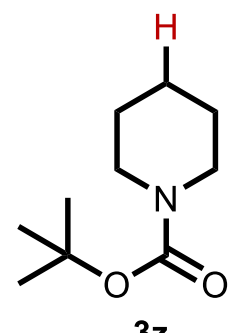

tert-butyl piperidinecarboxylate (3z): Synthesized according to general procedure A from 1-(t-butoxycarbonyl)-4-aminopiperidine (2z) (20 mg, 0.096 mmol) with the exception that $0.1 \mathrm{M}$ solution of anomeric amide reagent was added dropwise via syringe pump to a $0.1 \mathrm{M}$ solution of amine at a rate of 300 $\mu \mathrm{l} / \mathrm{h}$ and the reaction was subsequently stirred overnight. The crude reaction mixture was purified by silica gel chromatography and the title compound was obtained in 55\% yield $(9.8 \mathrm{mg}, 0.052 \mathrm{mmol}) . \quad \mathbf{R}_{\mathbf{f}}=0.85$ (7:3 hexanes/EtOAc). ${ }^{1} \mathbf{H}$ NMR (400 $\left.\mathrm{MHz}_{2} \mathrm{CDCl}_{3}\right): \delta 3.37-3.32(\mathrm{~m}, 4 \mathrm{H}), 1.58-1.53(\mathrm{~m}, 2 \mathrm{H}), 1.52-1.47(\mathrm{~m}, 4 \mathrm{H}), 1.44(\mathrm{~s}, 9 \mathrm{H})$. Spectroscopic data are in agreement with those in the literature. ${ }^{27}$

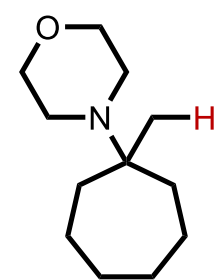

3aa

4-(1-methylcycloheptyl)morpholine (3aa): Synthesized according to general procedure A from (1-morpholin-4-ylcycloheptyl)methanamine (2aa) (100 mg, $0.471 \mathrm{mmol})$. The title compound was obtained in $67 \%$ yield $(62 \mathrm{mg}, 0.316$ mmol) after purification by silica gel chromatography. $\mathbf{R}_{\mathbf{f}}=0.4$ (1:1 hexanes/ethyl acetate). ${ }^{1} \mathbf{H}$ NMR (400 MHz, $\left.\mathrm{CDCl}_{3}\right): \delta 3.71-3.66(\mathrm{~m}, 4 \mathrm{H}), 2.54-2.50(\mathrm{~m}$, 4H), $1.82-1.75(\mathrm{~m}, 2 \mathrm{H}), 1.64-1.55(\mathrm{~m}, 4 \mathrm{H}), 1.53-1.44(\mathrm{~m}, 2 \mathrm{H}), 1.43-1.28(\mathrm{~m}, 4 \mathrm{H}), 0.90(\mathrm{~s}$, 3H). ${ }^{13} \mathbf{C}\left\{{ }^{1} \mathbf{H}\right\}\left(101 \mathrm{MHz}, \mathrm{CDCl}_{3}\right): \delta 68.0,58.8,46.3,38.0,29.6,22.9,22.1$. HRMS (ESI) calculated 197.1780 for $\mathrm{C}_{12} \mathrm{H}_{23} \mathrm{NO}$, found 197.1764.

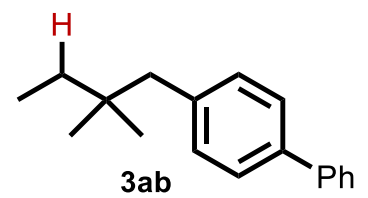
2,2-dimethyl-1-biphenylbutane (3ab): Synthesized according to the general procedure A from 4-(1,1'-biphenyl-4-yl)-3,3-dimethylbutan-2amine (2ab) (16.8 $\mathrm{mg}, 0.0663 \mathrm{mmol})$. The title compound was obtained in $85 \%$ yield $(13.4 \mathrm{mg}, 0.056 \mathrm{mmol})$ after purification by silica gel chromatography. $\mathbf{R}_{\mathbf{f}}=0.5$ (100\% hexanes). ${ }^{1} \mathbf{H}$ NMR $\left(400 \mathrm{MHz}, \mathrm{CDCl}_{3}\right): \delta 7.61(, \mathrm{~J}=7.5 \mathrm{~Hz}, 2 \mathrm{H}), 7.51(\mathrm{~d}, \mathrm{~J}=8.3 \mathrm{~Hz}$, 2H), $7.44(\mathrm{t}, \mathrm{J}=7.8 \mathrm{~Hz}, 2 \mathrm{H}), 7.33(\mathrm{t}, \mathrm{J}=7.6 \mathrm{~Hz}, 1 \mathrm{H}), 7.21(\mathrm{~J}=8.1 \mathrm{~Hz}, 2 \mathrm{H}), 2.55(\mathrm{~s}, 2 \mathrm{H}), 1.31$ (q, $\mathrm{J}=7.7 \mathrm{~Hz}, 2 \mathrm{H}), 0.93(\mathrm{t}, \mathrm{J}=7.4 \mathrm{~Hz}, 3 \mathrm{H}), 0.88(\mathrm{~s}, 6 \mathrm{H})$. Spectroscopic data are in agreement with those in the literature. ${ }^{28}$ 


\section{Diazene - Isodiazene Comparison}

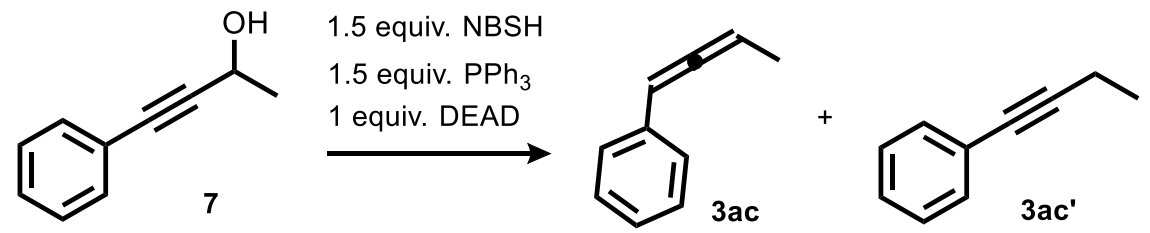

Myers allene synthesis was performed according to the previously reported procedure. ${ }^{29}$ To a deoxygenated solution of triphenylphosphine (269 mg, $1.026 \mathrm{mmol}, 1.5$ equiv.) in $2 \mathrm{ml} \mathrm{THF}$ was added DEAD (40 wt\% solution in toluene, $202 \mu \mathrm{l}, 1$ equiv.) and the flask was cooled to $-15{ }^{\circ} \mathrm{C}$ using 1:3 mass sodium chloride ice water bath. Deoxygenated solutions of 4-phenylbut-3-yn-2-

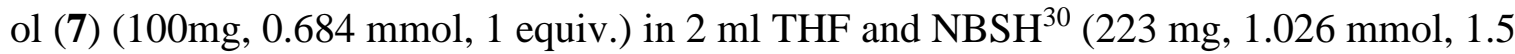
equiv.). in $2 \mathrm{ml}$ THF were subsequently added dropwise. The reaction was stirred at $-15^{\circ} \mathrm{C}$ for 2 hours and then allowed to warm to room temperature overnight. The volatiles were removed in vacuo and the crude material was purified by silica gel chromatography to yield 3ac and 3ac' in $37 \%$ yield (33 mg, $0.253 \mathrm{mmol}$ ). The product was analyzed by NMR spectroscopy and the ratio of 3ac to 3ac' was determined by comparison to literature spectra of the compounds. ${ }^{29,31}$ This procedure was repeated three times and the average ratio of 3ac to 3ac' was $138+/-32: 1$.

${ }^{1} \mathrm{H}$ NMR Mixture of 3ac and 3ac' in $\mathrm{CDCl}_{3}, 400 \mathrm{MHz}$ :

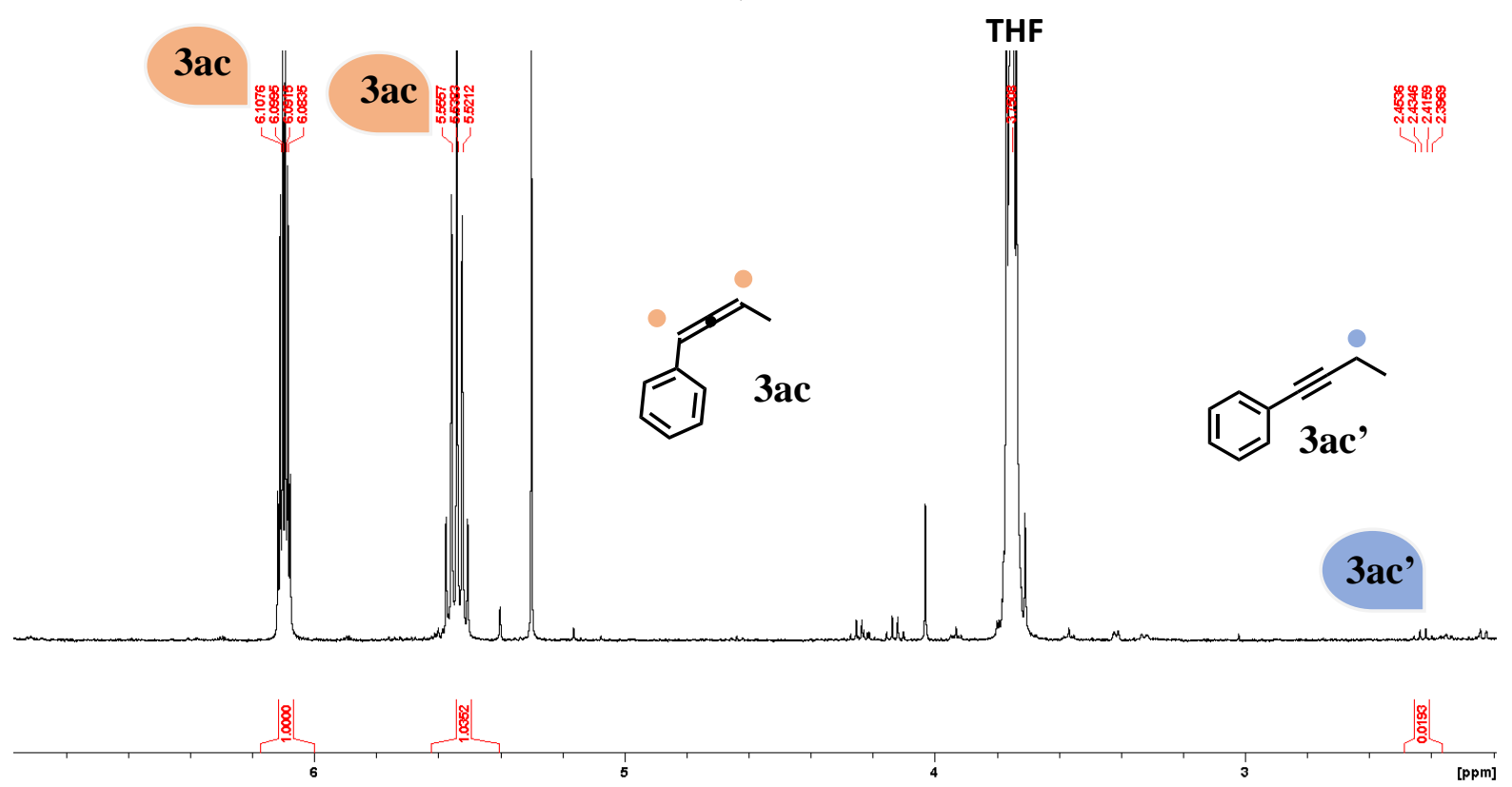




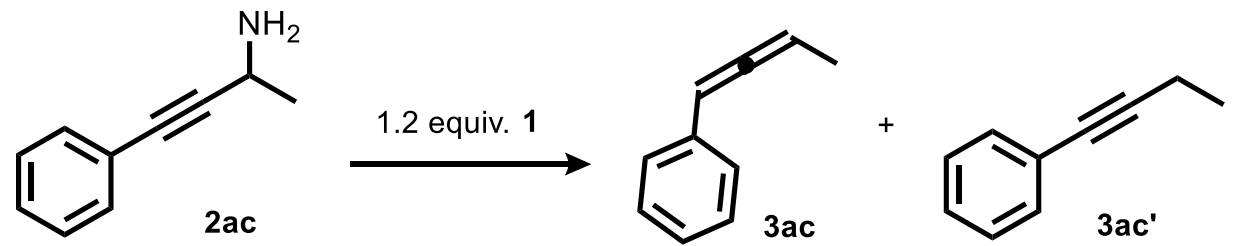

Note: This reaction was conducted in THF instead of the optimized solvent acetonitrile for direct comparison to the Myers allene synthesis, which resulted in a lower isolated yield of product. When acetonitrile is used as solvent, the yield of 3ac and 3ac' increased to $25 \%$.

To a deoxygenated solution of anomeric amide ( $326 \mathrm{mg}, 0.826 \mathrm{mmol}, 1.2$ equiv.) in $4 \mathrm{ml}$ THF was added a deoxygenated solution of 4-phenylbut-3-yn-2-amine (100 mg, $0.689 \mathrm{mmol})$ in $4 \mathrm{ml}$ THF over 15 minutes and the solution was stirred at room temperature for 1 hour. The volatiles were removed in vacuo and the crude material was purified by silica gel chromatography to yield 3ac and 3ac' in 7\% yield $(6.3 \mathrm{mg}, 0.0482 \mathrm{mmol})$. The product was analyzed by NMR spectroscopy and the ratio of 3ac to 3ac' was determined by comparison to literature spectra of the compounds. ${ }^{29,} 31$ This procedure was repeated three times and the average ratio of 3ac to 3ac' was $8+/-0.6: 1$.

\section{${ }^{1} \mathrm{H}$ NMR Mixture of $3 \mathrm{ac}$ and $3 \mathrm{ac}$ ' in $\mathrm{CDCl}_{3}, 400 \mathrm{MHz}$ :}

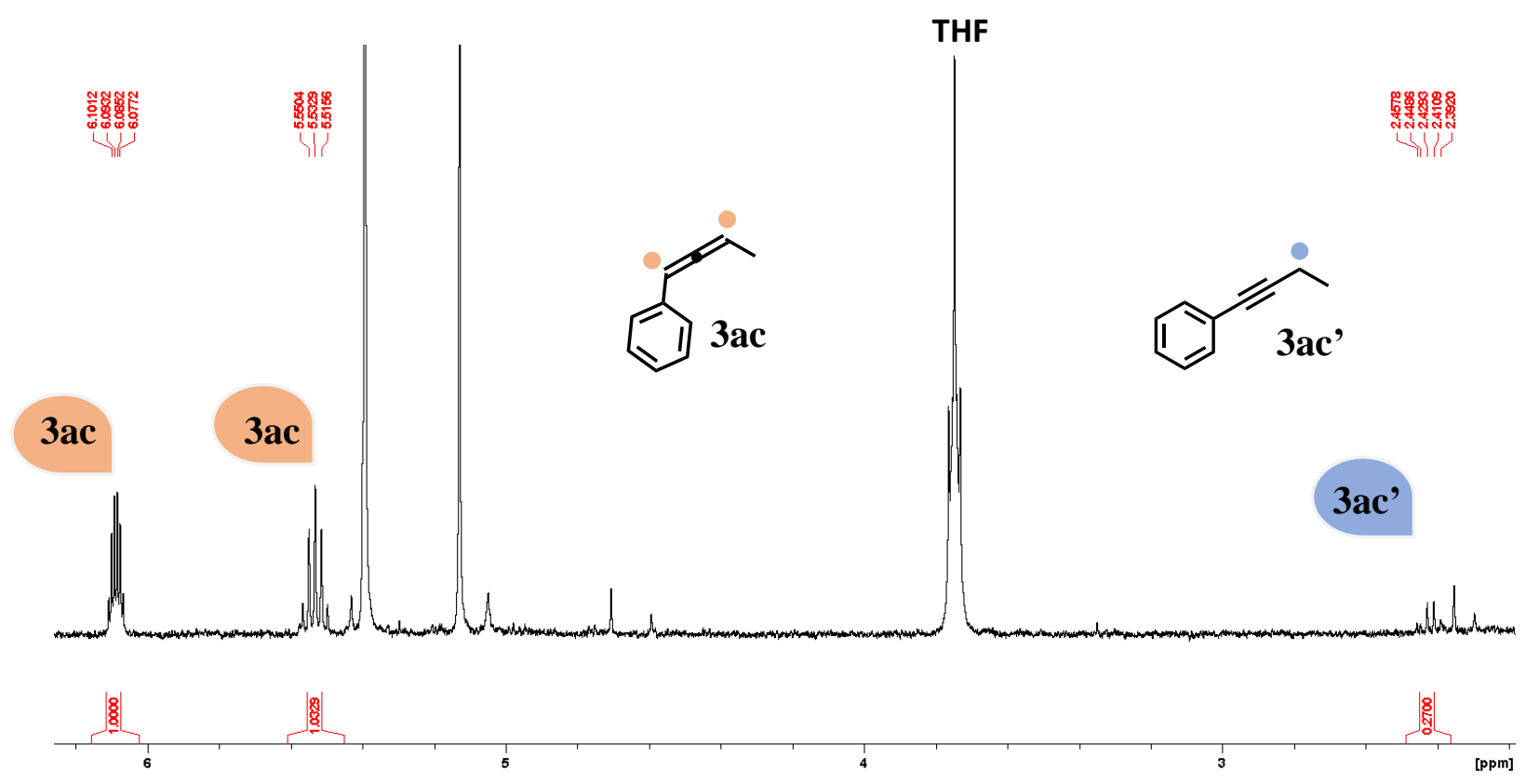




\section{Deuterium Labelling Studies}

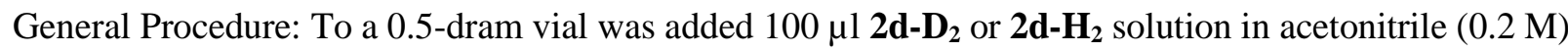
followed by $100 \mu \mathrm{l}$ solution in acetonitrile ( $0.24 \mathrm{M}$ in $\mathbf{1})$, added slowly under nitrogen. After 1 hour, $\mathrm{CD}_{3} \mathrm{CN}$ was added (400 $\left.\mu \mathrm{l}\right)$ and the deuterium incorporation was assessed by NMR. After multipoint baseline correction, the deuterium content of $\mathbf{3 d}$ was assessed by integration against the methylene indicated. In reactions where $\mathrm{D}_{2} \mathrm{O}$ was added as a co-solvent, the amine solution was prepared in $8 \% \mathrm{D}_{2} \mathrm{O}$ in acetonitrile by volume (same total volume as above), and the procedure was otherwise identical.

\section{${ }^{1} \mathrm{H}$ NMR of Crude Deuterium Labelling Experiment in $\mathrm{CD}_{3} \mathrm{CN}, 400 \mathrm{MHz}$ :}

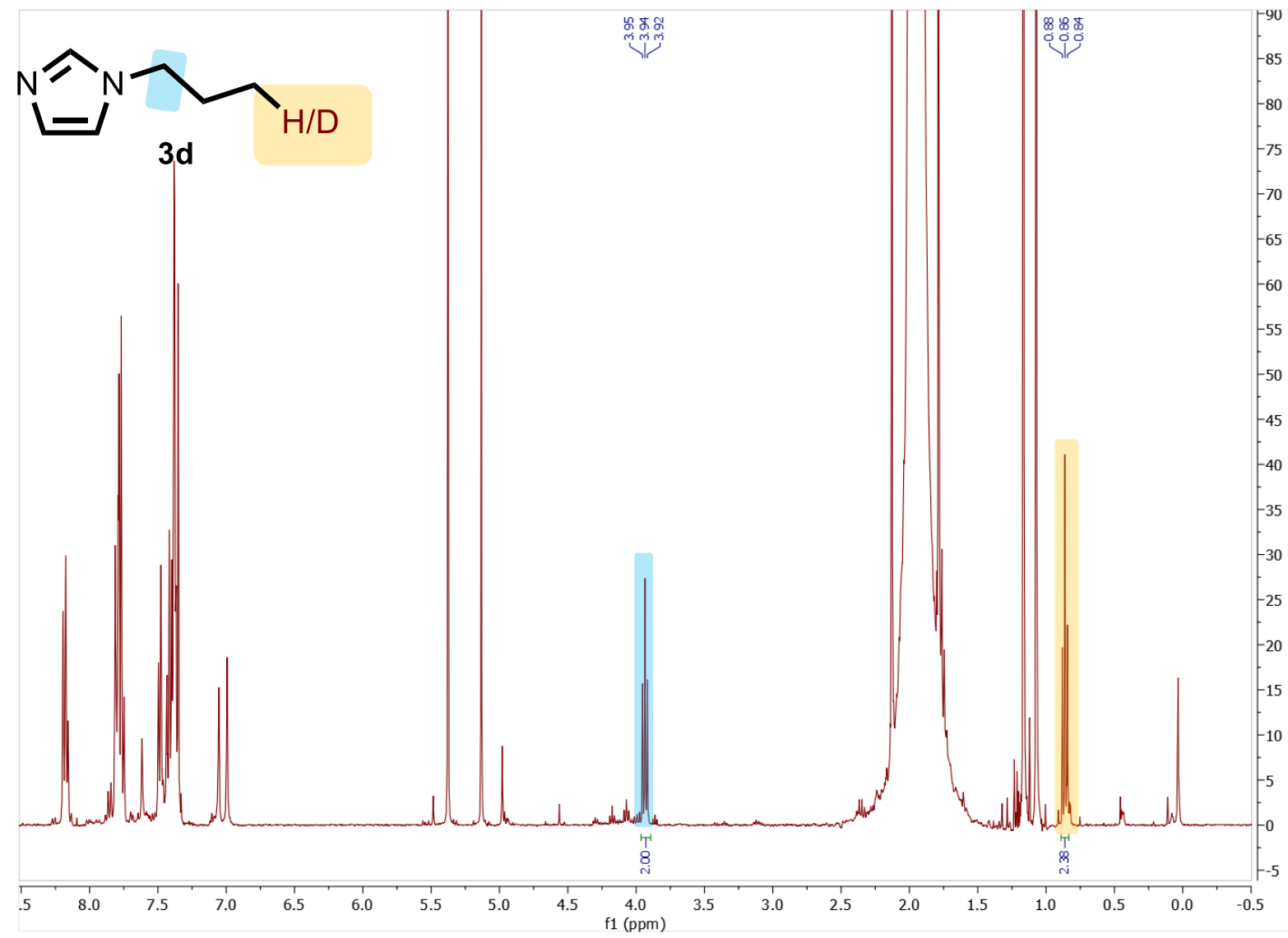




\section{TEMPO Trapping Studies}

\section{1 - Radical trapping of $2 \mathrm{ag}$ with TEMPO}<smiles>Cc1ccc(OC2(C)CCCC(C)(C)N2c2ccc(C)cc2)cc1</smiles>

To a 1-dram screw cap vial equipped with a stir bar and PTFE/white silicone septum was added $p$-toluidine (12 mg, $0.11 \mathrm{mmol}, 1$ equiv), TEMPO free radical (21 mg, $0.13 \mathrm{mmol}, 1.2$ equiv.) and dry $\mathrm{CD}_{3} \mathrm{CN}(0.5$ $\mathrm{mL})$ under nitrogen. The anomeric amide $\left(65 \mathrm{mg}, 0.16 \mathrm{mmol}, 1.5\right.$ equiv) and dry $\mathrm{CD}_{3} \mathrm{CN}(0.5 \mathrm{~mL})$ was added to a second vial and this solution was then transferred to the first vial containing $p$-toluidine under nitrogen and stirred at $45^{\circ} \mathrm{C}$ for 24 hours. After $24 \mathrm{~h}, 1,3,5$-trimethoxybenzene $\left(100 \mu \mathrm{L}\right.$ solution in $\mathrm{CD}_{3} \mathrm{CN}$, $0.01 \mathrm{mmol}$ ) was added to the crude reaction mixture as internal standard. The ${ }^{1} \mathrm{H}$ NMR yield was $55 \%$ yield for $\mathbf{8 a g}^{32}$ and $15 \%$ yield for $\mathbf{3 a g}$.

\section{TEMPO trapping of 2ag. ${ }^{1} \mathrm{H} \mathrm{NMR}$ in $\mathrm{CD}_{3} \mathrm{CN}$ at $400 \mathrm{MHz}$}
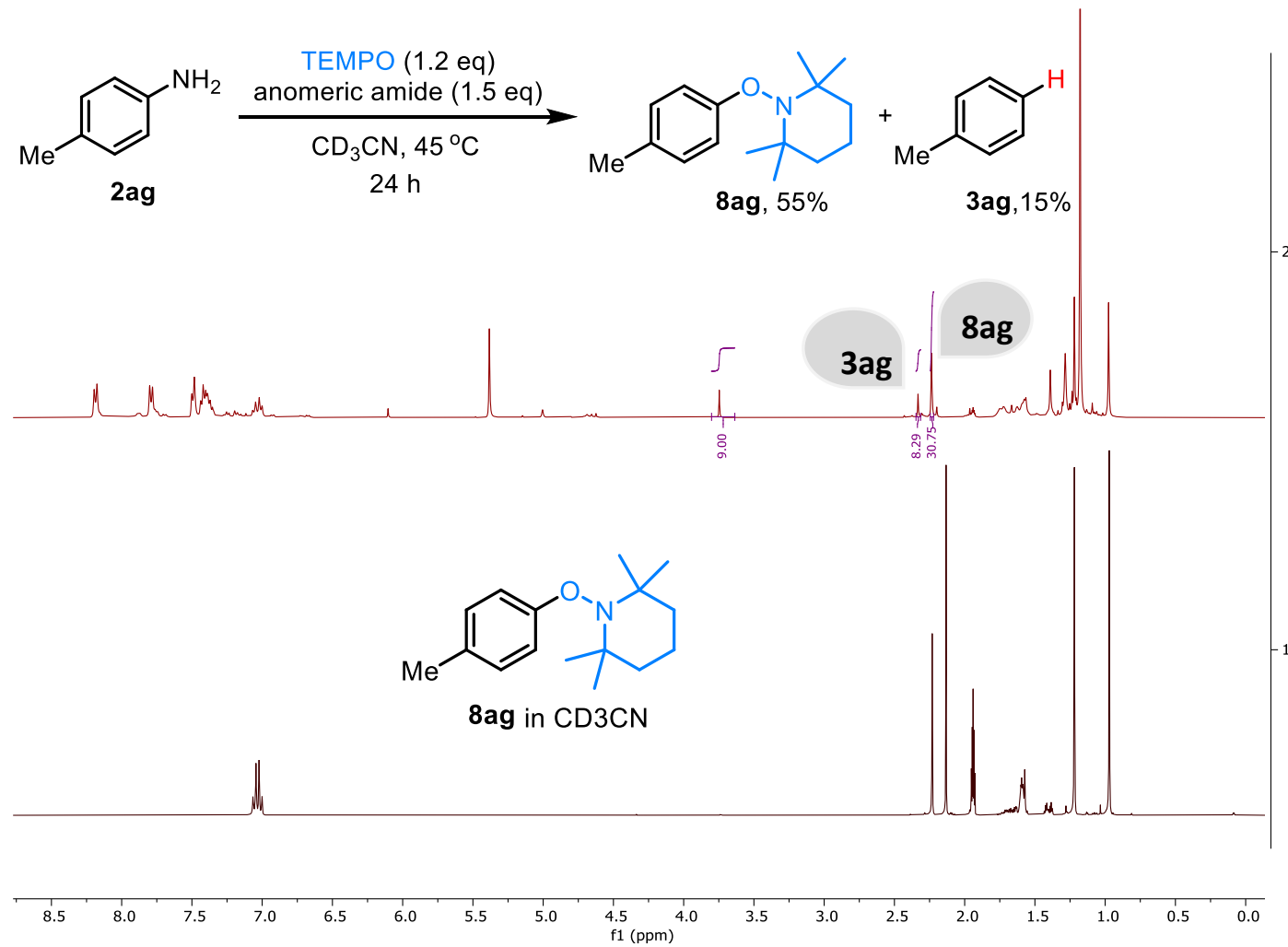


\section{2 - Radical Trapping of $2 \mathrm{a}$ and $2 \mathrm{~d}$}

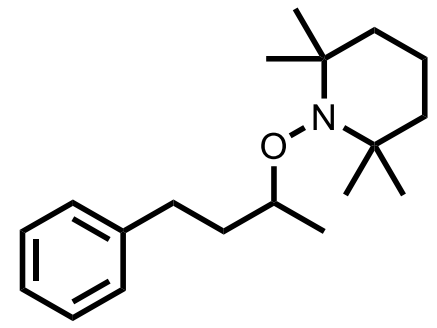

$8 \mathbf{a}$

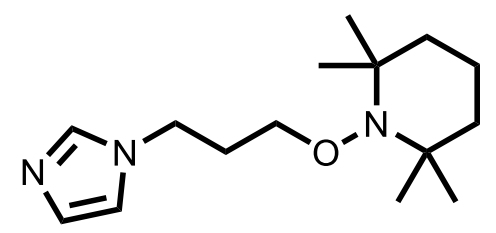

8d

To a 0.5 -dram vial was added $100 \mu \mathrm{l} \mathbf{2 a}$ or $\mathbf{2 d}$ solution in $\mathrm{CD}_{3} \mathrm{CN}(0.4 \mathrm{M})$ followed by $100 \mu \mathrm{TEMPO}$ radical solution in $\mathrm{CD}_{3} \mathrm{CN}(0.48 \mathrm{M})$. A $200 \mu$ l solution of $\mathbf{1}$ in $\mathrm{CD}_{3} \mathrm{CN}(0.24 \mathrm{M}$ in $\mathbf{1})$ was then added slowly under nitrogen. After 1 hour, 1,3,5-trimethoxybenzene was added as an internal standard to determine the yield by ${ }^{1} \mathrm{H}-\mathrm{NMR}$. Spectroscopic data for $\mathbf{8 a}$ is in agreement with the literature ${ }^{33}$ and $\mathbf{8 d}$ was isolated and fully characterized.

TEMPO trapping of 2a. ${ }^{1} \mathrm{H}$ NMR of Crude Reaction Mixture in $\mathrm{CD}_{3} \mathrm{CN}$ at $400 \mathrm{MHz}$

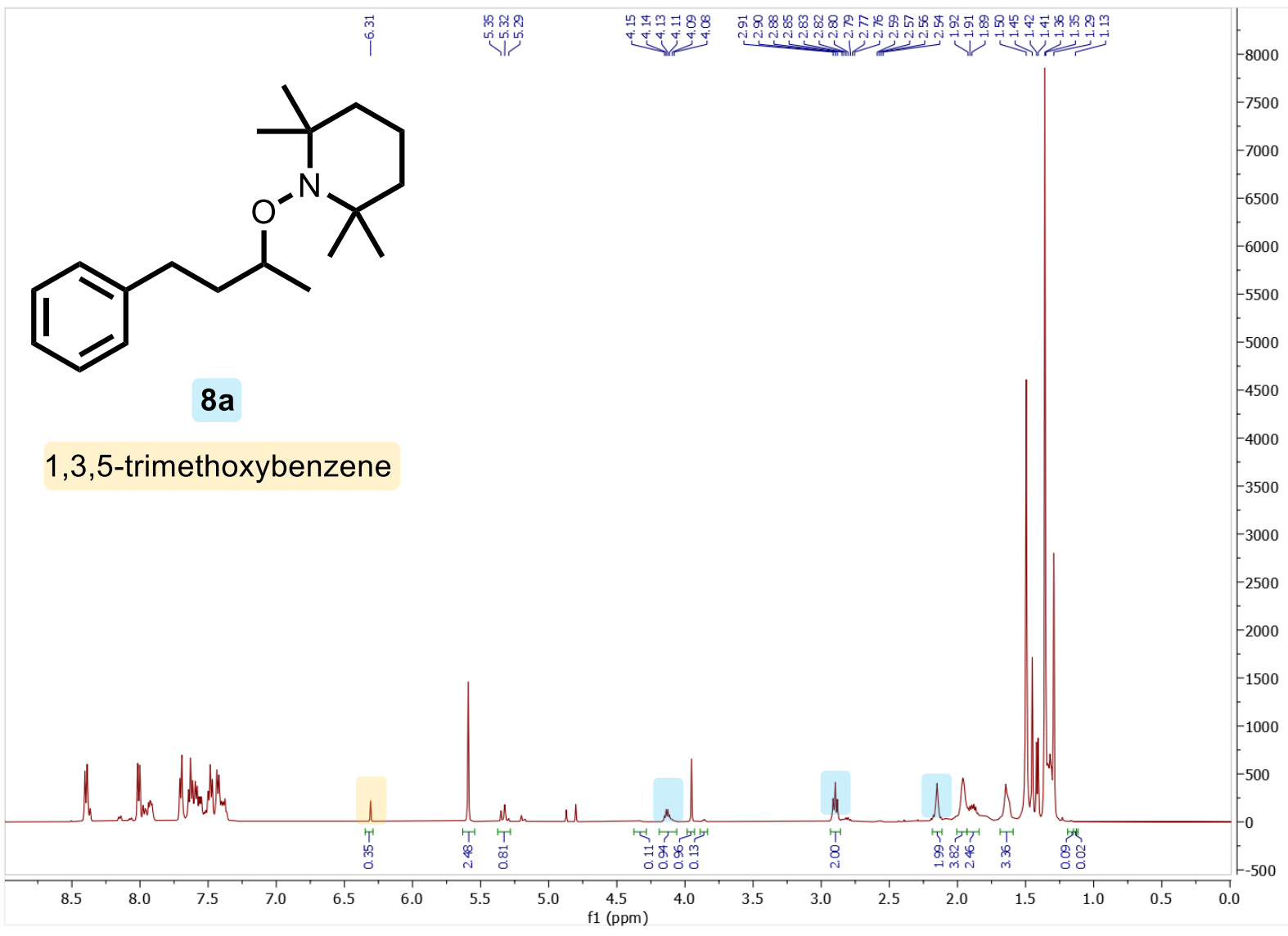


TEMPO trapping of $2 \mathrm{~d} .{ }^{1} \mathrm{H}$ NMR of Crude Reaction Mixture $\mathrm{CD}_{3} \mathrm{CN}$ at $400 \mathrm{MHz}$
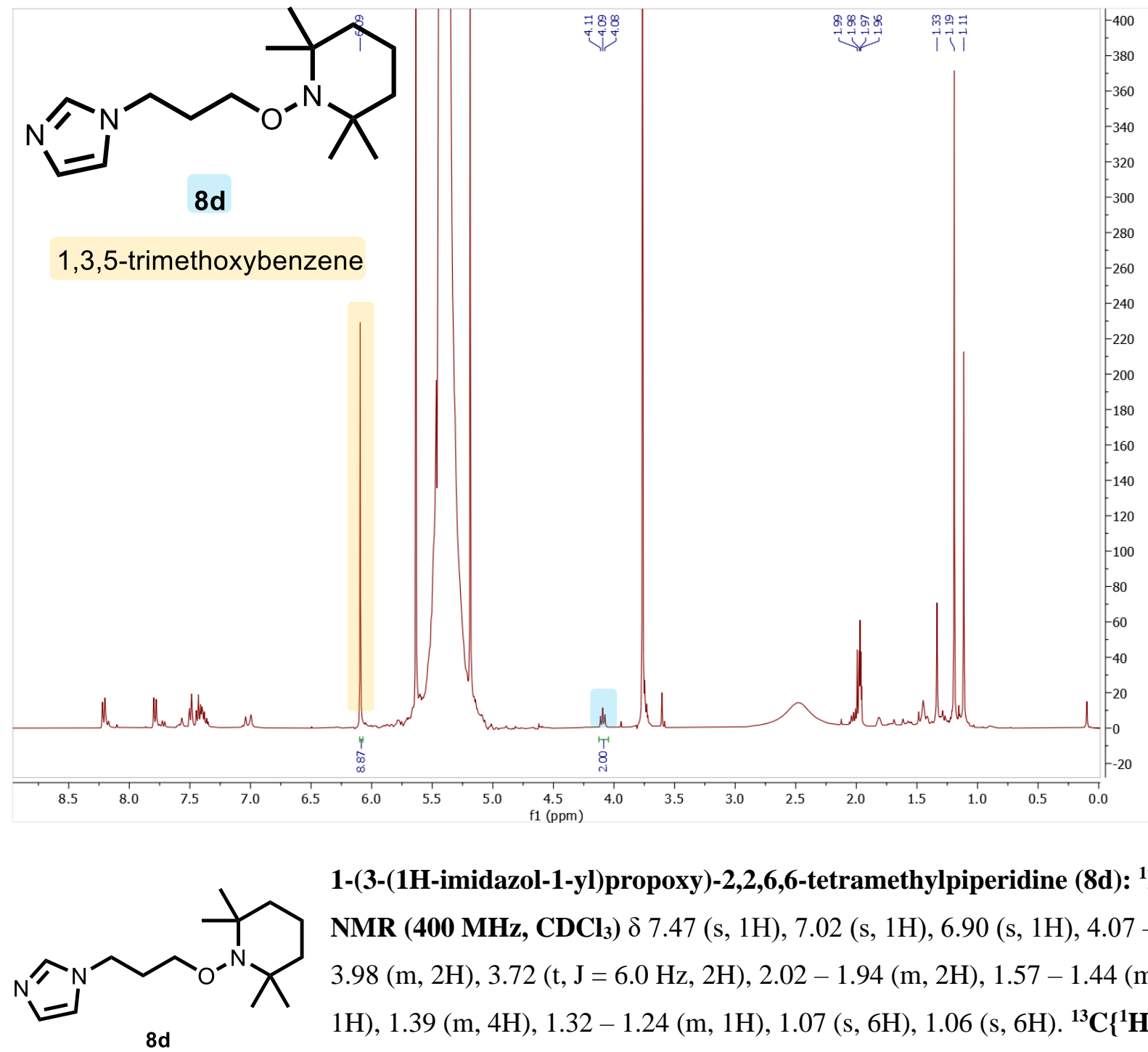

1-(3-(1H-imidazol-1-yl)propoxy)-2,2,6,6-tetramethylpiperidine (8d): ${ }^{1} \mathrm{H}$ NMR (400 MHz, $\left.\mathbf{C D C l}_{3}\right) \delta 7.47$ (s, 1H), $7.02(\mathrm{~s}, 1 \mathrm{H}), 6.90$ (s, 1H), $4.07-$ $3.98(\mathrm{~m}, 2 \mathrm{H}), 3.72(\mathrm{t}, \mathrm{J}=6.0 \mathrm{~Hz}, 2 \mathrm{H}), 2.02-1.94(\mathrm{~m}, 2 \mathrm{H}), 1.57-1.44(\mathrm{~m}$, 1H), 1.39 (m, 4H), $1.32-1.24(\mathrm{~m}, 1 \mathrm{H}), 1.07$ (s, 6H), $1.06(\mathrm{~s}, 6 \mathrm{H}) .{ }^{13} \mathbf{C}\left\{{ }^{1} \mathbf{H}\right\}$ NMR (101 MHz, $\left.\mathbf{C D C l}_{3}\right) \delta 137.11,129.34,118.78,77.48,77.16,76.84$,

72.87, 59.73, 44.36, 39.56, 33.08, 30.56, 20.09, 17.05. HR-MS (ESI): calculated 265.2154 for $\mathrm{C}_{15} \mathrm{H}_{27} \mathrm{~N}_{3} \mathrm{O}$, found 265.2171 . 


\section{Radical and Anion Clock Experiments}

\section{1 - Aromatic Radical Clock}
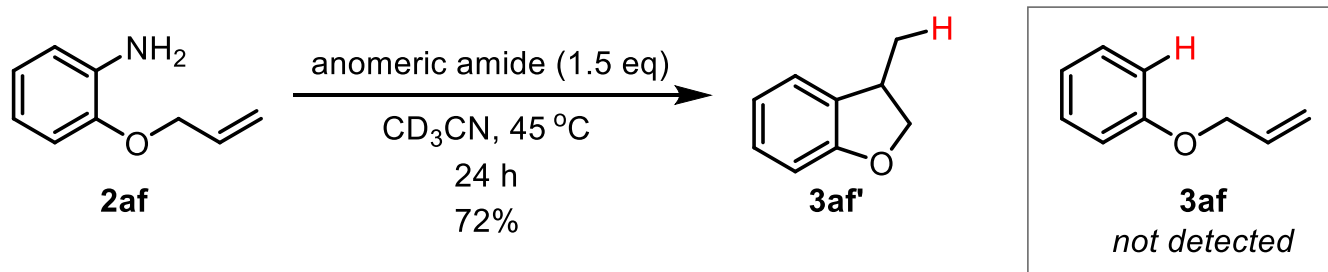

To a 1-dram screw cap vial equipped with a stir bar and PTFE/white silicone septum was added 2(allyloxy)aniline (2af) (15 mg, $0.1 \mathrm{mmol}, 1$ equiv) and dry $\mathrm{CD}_{3} \mathrm{CN}(0.5 \mathrm{~mL})$ under nitrogen. The anomeric amide (59 mg, $0.15 \mathrm{mmol}, 1.5$ equiv) and dry $\mathrm{CD}_{3} \mathrm{CN}(0.5 \mathrm{~mL})$ was added to a second vial and this solution was then transferred to the first vial containing $p$-toluidine under nitrogen and stirred at $45^{\circ} \mathrm{C}$ for 24 hours. After $24 \mathrm{~h}, 1,3,5$-trimethoxybenzene $\left(100 \mu \mathrm{L}\right.$ solution in $\left.\mathrm{CD}_{3} \mathrm{CN}, 0.01 \mathrm{mmol}\right)$ was added to the crude reaction mixture as internal standard. $72 \%$ yield of 3af' was obtained via ${ }^{1} \mathrm{H}$ NMR. ${ }^{34}$

\section{Radical clock experiment with 2af, ${ }^{1} \mathrm{H}$ NMR in $\mathrm{CD}_{3} \mathrm{CN}$ at $400 \mathrm{MHz}$ :}

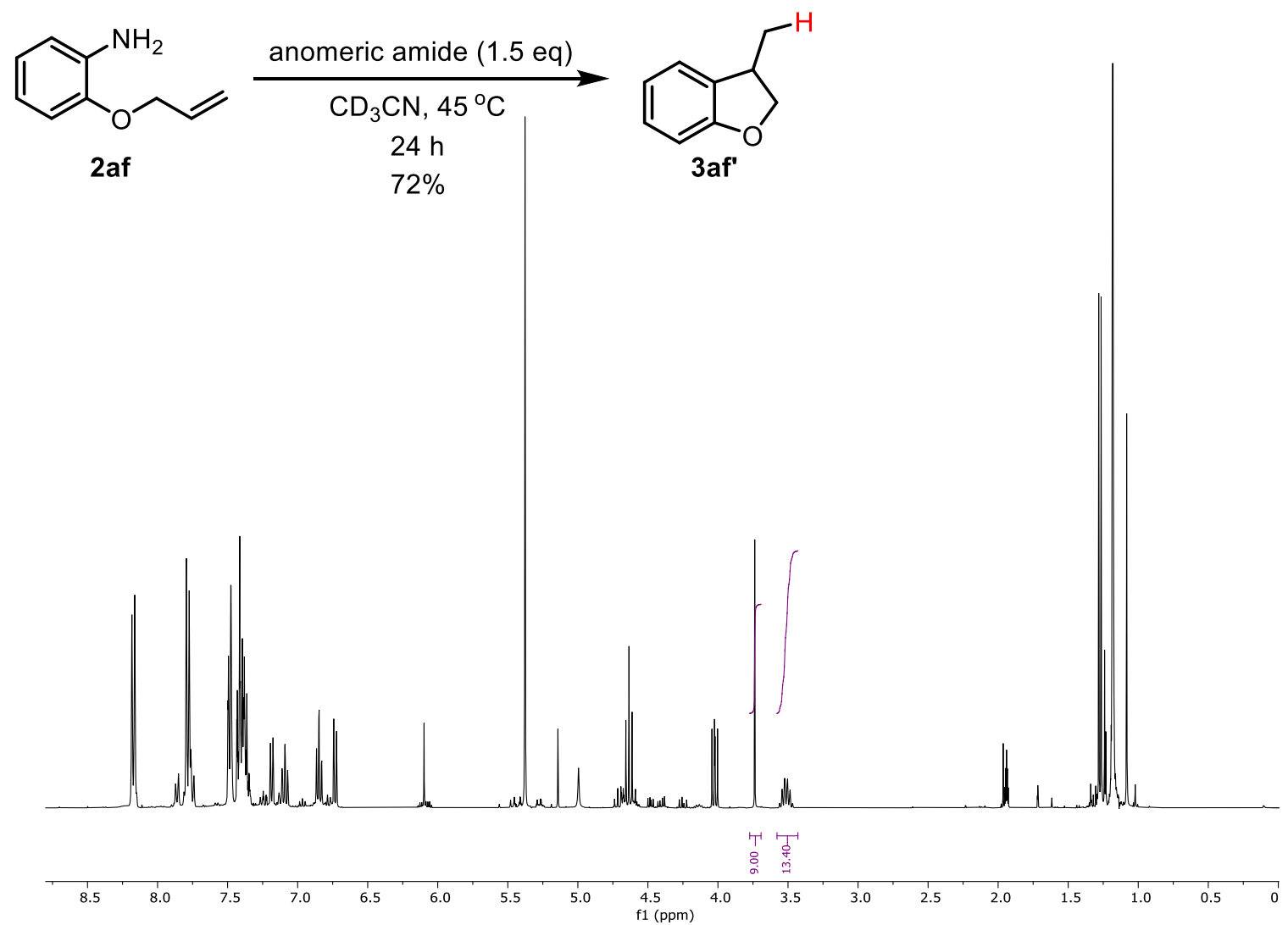




\section{2 - Nitrogen Radical Clock}

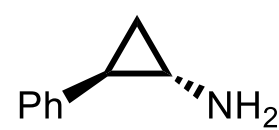

2ai

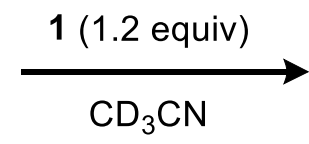

$\mathrm{CD}_{3} \mathrm{CN}$$$
\text { (n) }
$$

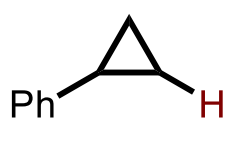

3ai<smiles>[Y]=CCCc1ccccc1</smiles>

$Y=N R, O$

not detected

To a 2-dram screw cap vial equipped with a stir bar and PTFE/white silicone septum was added trans-2phenylcyclopropylamine (2ai) (45.9 mg, $345 \mathrm{mmol}, 1$ equiv) and dry $\mathrm{CD}_{3} \mathrm{CN}$ (1.7 mL) under nitrogen. The anomeric amide (164 mg, 1.2 equiv) and dry $\mathrm{CD}_{3} \mathrm{CN}(1.7 \mathrm{~mL})$ was added to a second vial and cooled to $0{ }^{\circ} \mathrm{C}$. The amine solution was added to the anomeric amide solution over 7 minutes and the reaction was stirred for one hour at $0{ }^{\circ} \mathrm{C}$. Then, 1,3,5-trimethoxybenzene $(1.4 \mathrm{mg})$ was added to a $0.6 \mathrm{~mL}$ aliquot of the crude reaction (measured to be $2.8 \mathrm{~mL}$ total at end of reaction) as internal standard. $74 \%$ yield of 3ai was obtained via ${ }^{1} \mathrm{H}$ NMR. ${ }^{35}$

\section{${ }^{1} \mathrm{H}$ NMR of Crude Nitrogen Radical Clock Reaction in $\mathrm{CD}_{3} \mathrm{CN}, 400 \mathrm{MHz}$ :}

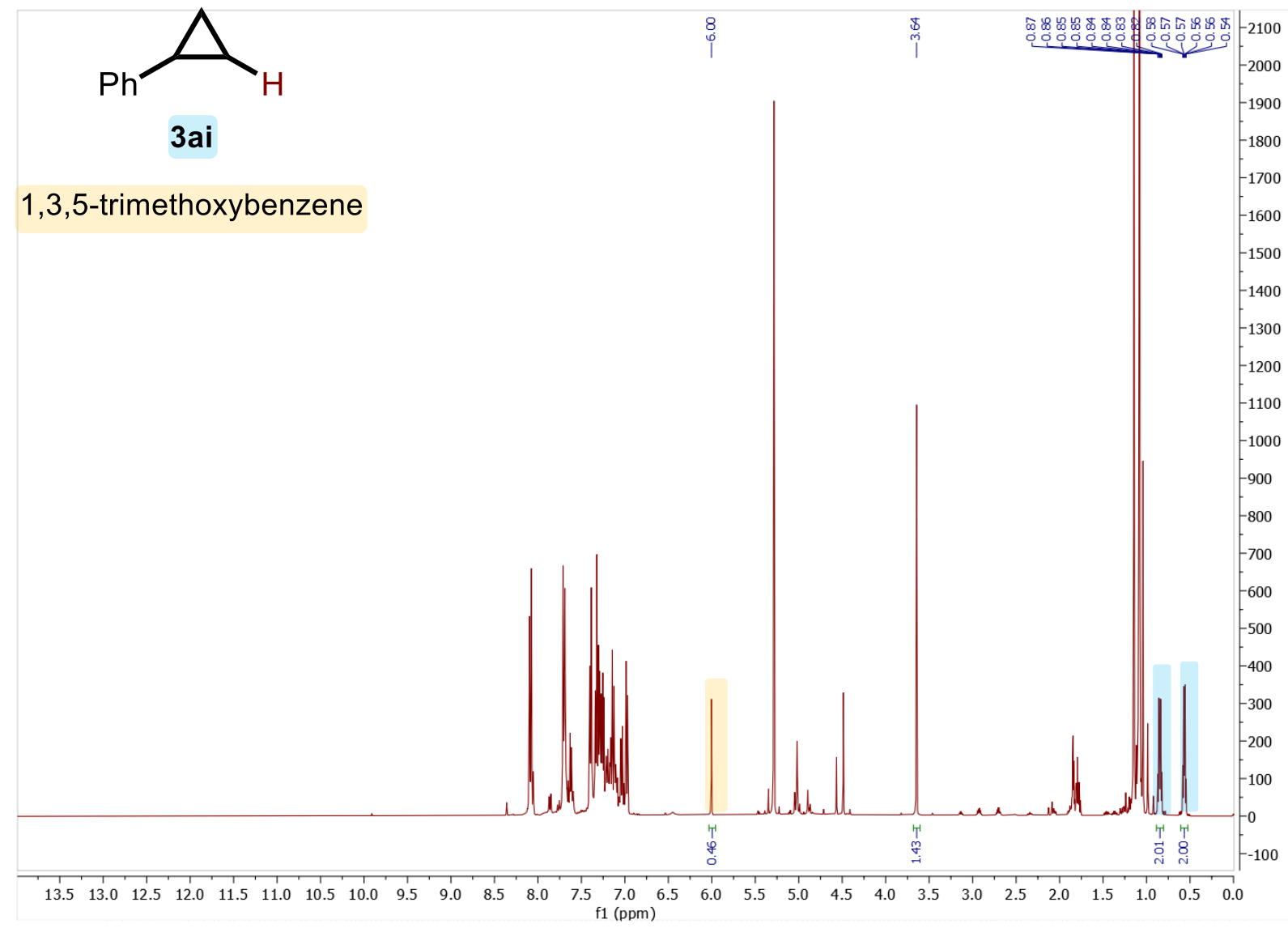




\section{3 - Anion Clock}<smiles>COC(=O)C(C)(CN)C(=O)OC</smiles>

2ad

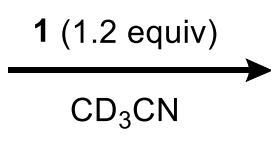

$\mathrm{CD}_{3} \mathrm{CN}$<smiles>COC(=O)C(C)(C)C(=O)OC</smiles>

3ad<smiles>COC(=O)CC(C)C(=O)OC</smiles>

not observed

To a 1-dram screw cap vial equipped with a stir bar and PTFE/white silicone septum was added dimethyl 2-(aminomethyl)-2-methylmalonate (2ad) $\left(12.7 \mathrm{mg}, 72.7 \mathrm{mmol}, 1\right.$ equiv) and dry $\mathrm{CD}_{3} \mathrm{CN}(0.5 \mathrm{~mL})$ under nitrogen. The anomeric amide (34.5 mg, 1.2 equiv) and dry $\mathrm{CD}_{3} \mathrm{CN}(0.5 \mathrm{~mL})$ was added to a second vial and this solution was then transferred to the first vial under nitrogen and stirred at room temperature for 1 hour. Then, 1,3,5-trimethoxybenzene $(1.1 \mathrm{mg})$ was added to the crude reaction mixture as internal standard. 98\% yield of $\mathbf{3 a d}$ was obtained via ${ }^{1} \mathrm{H}$ NMR. ${ }^{36}$

\section{${ }^{1} \mathrm{H}$ NMR of Crude Anion Clock Reaction in $\mathrm{CD}_{3} \mathrm{CN}, 400 \mathrm{MHz}$ :} ${ }^{1} \mathrm{H} N M R\left(400 \mathrm{MHz}, \mathrm{CD}_{3} \mathrm{CN}\right) \delta 3.67(\mathrm{~s}, 6 \mathrm{H}), 1.38(\mathrm{~s}, 6 \mathrm{H})$.<smiles>COC(=O)C(C)(C)C(=O)OC</smiles>

1,3,5-trimethoxybenzene

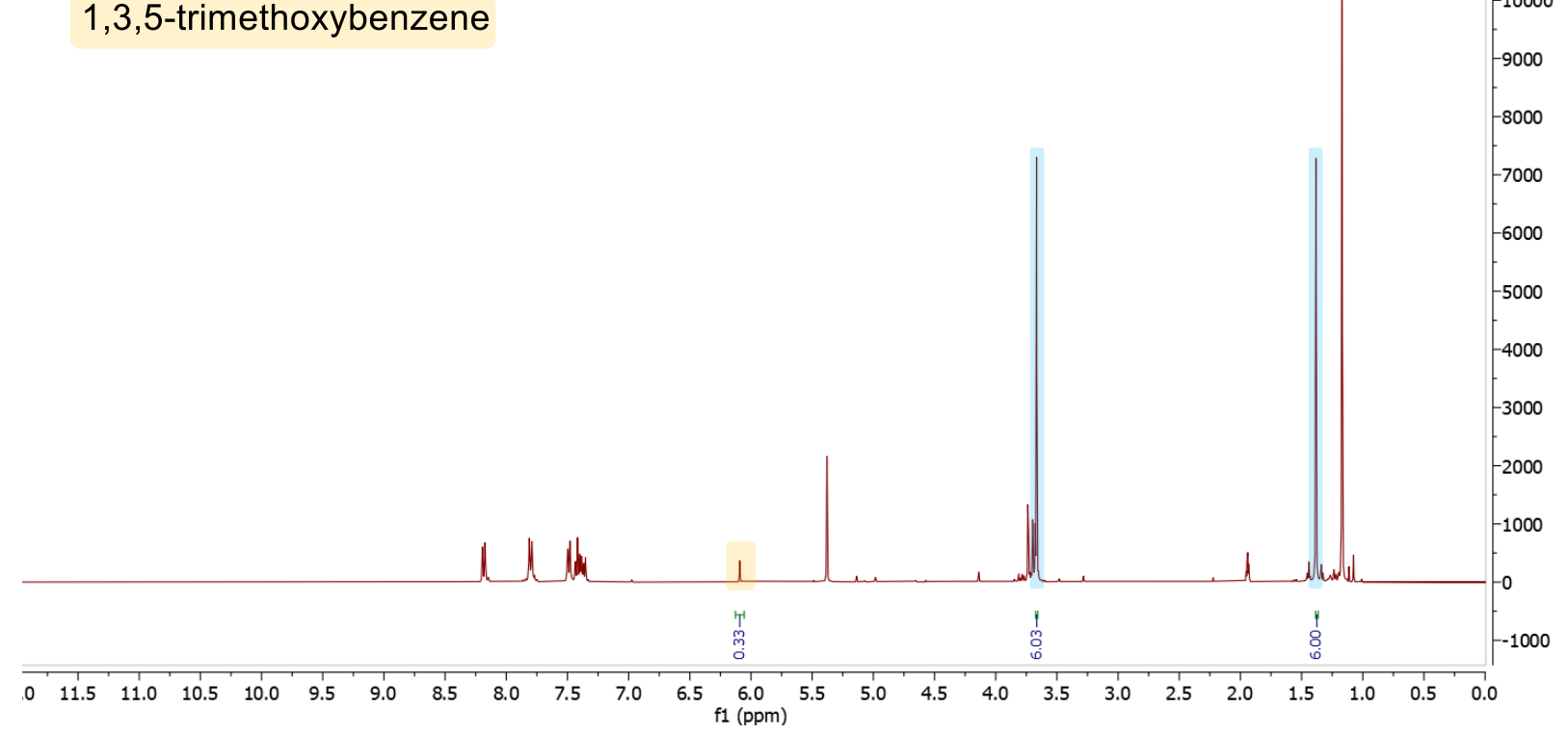


4 - Aliphatic Radical Clock<smiles>NCCCCC=C(c1ccccc1)c1ccccc1</smiles>

2ae

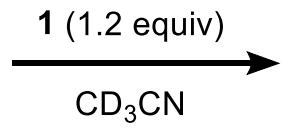

$3 a e^{\prime}$

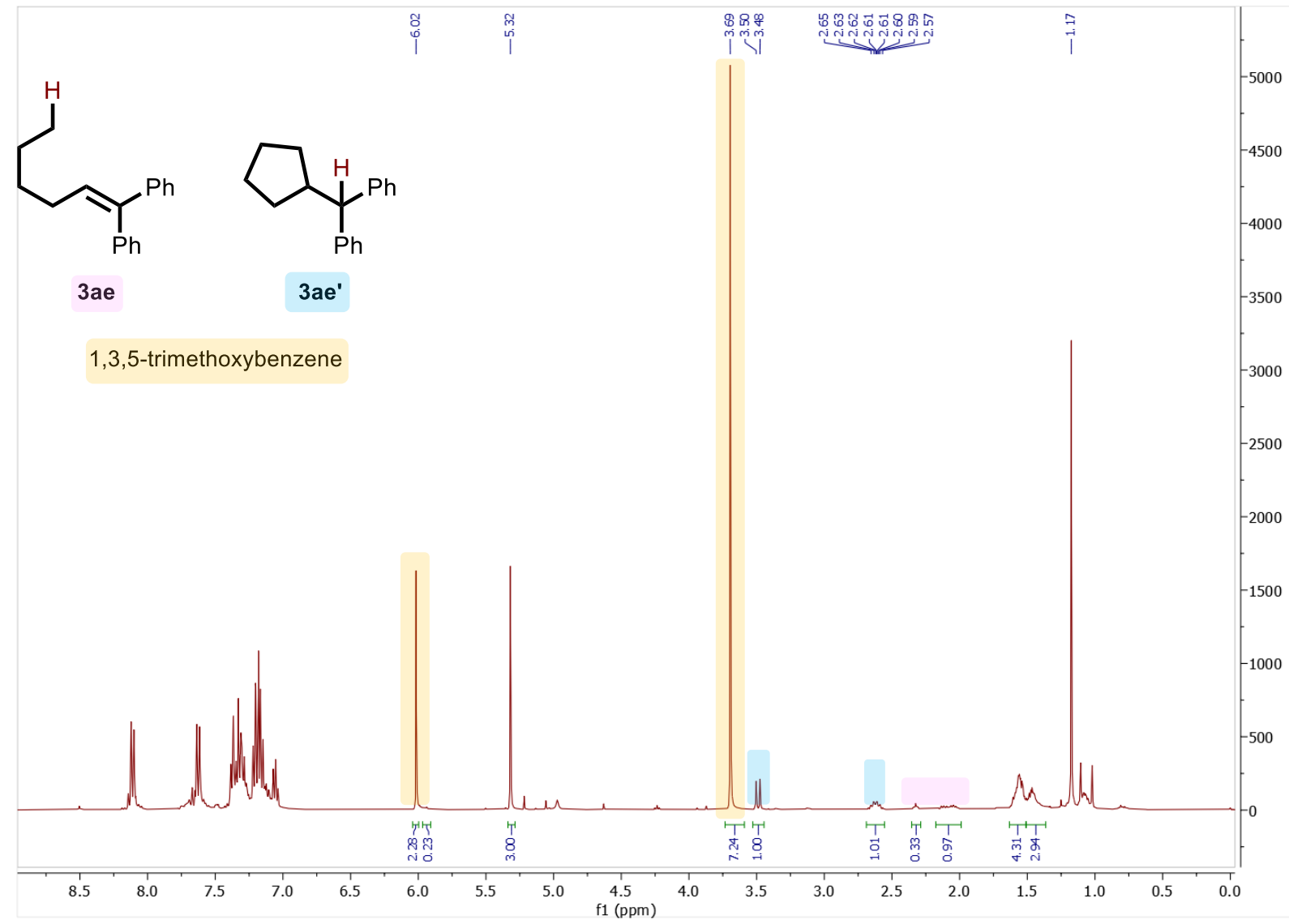<smiles>CCCCC=C(c1ccccc1)c1ccccc1</smiles>

3ae<smiles>c1ccc(C(c2ccccc2)C2CCCC2)cc1</smiles>

3ae'

To a 1-dram screw cap vial equipped with a stir bar and PTFE/white silicone septum was added 6,6diphenylhex-5-en-1-amine (2ae) (10.2 mg, $39.8 \mathrm{mmol}, 1$ equiv) and dry $\mathrm{CD}_{3} \mathrm{CN}(0.4 \mathrm{~mL})$ under nitrogen. The anomeric amide (20.4 mg, 1.3 equiv) and dry $\mathrm{CD}_{3} \mathrm{CN}(0.4 \mathrm{~mL})$ was added to a second vial and this solution was then transferred to the first vial under nitrogen and stirred at room temperature for 1 hour. Then, 1,3,5-trimethoxybenzene $(2.2 \mathrm{mg})$ was added to the crude reaction mixture as internal standard. $41 \%$ yield of 3ae and $7 \%$ yield of 3ae' were obtained via ${ }^{1} \mathrm{H}$ NMR. ${ }^{37}$

\section{${ }^{1} \mathrm{H}$ NMR of Crude Aliphatic Clock Reaction in $\mathrm{CD}_{3} \mathrm{CN}, 400 \mathrm{MHz}$ :}




\section{Reaction Limitations - Benzylic Substrates}

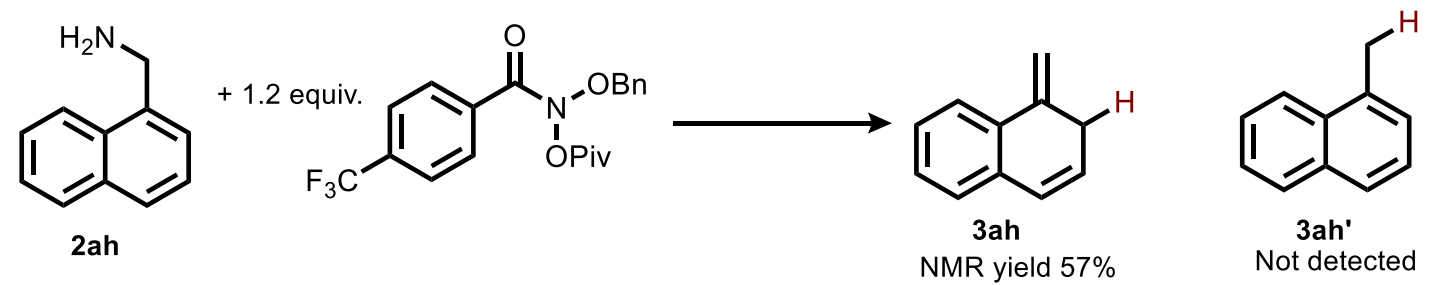

To a 1-dram screw cap vial equipped with a stir bar and PTFE/white silicone septum was added (naphth-1yl)methylamine (10 mg, $0.06361 \mathrm{mmol}, 1$ equiv) and dry $\mathrm{CH}_{3} \mathrm{CN}(0.5 \mathrm{~mL})$ under nitrogen. The anomeric amide (31 mg, $0.07633 \mathrm{mmol}, 1.2$ equiv) and dry $\mathrm{CH}_{3} \mathrm{CN}(0.5 \mathrm{~mL})$ was added to a second vial and this solution was then transferred to the first vial containing $p$-toluidine under nitrogen and stirred at room temperature for 1 hour. After 1 hour, 1,3,5-trimethoxybenzene $(4.5 \mathrm{mg}, 0.0268 \mathrm{mmol})$ was added to the crude reaction mixture, the volatiles were removed in vacuo and the crude material was dissolved in $\mathrm{CDCl}_{3}$. $57 \%$ yield of 1-methylene-1,2-dihydronaphthalene was obtained via ${ }^{1} \mathrm{H}$ NMR. ${ }^{38}$

\section{${ }^{1} \mathrm{H}$ NMR spectrum of crude benzylic reaction mixture in $\mathrm{CDCl}_{3}, 400 \mathrm{MHz}$ :}
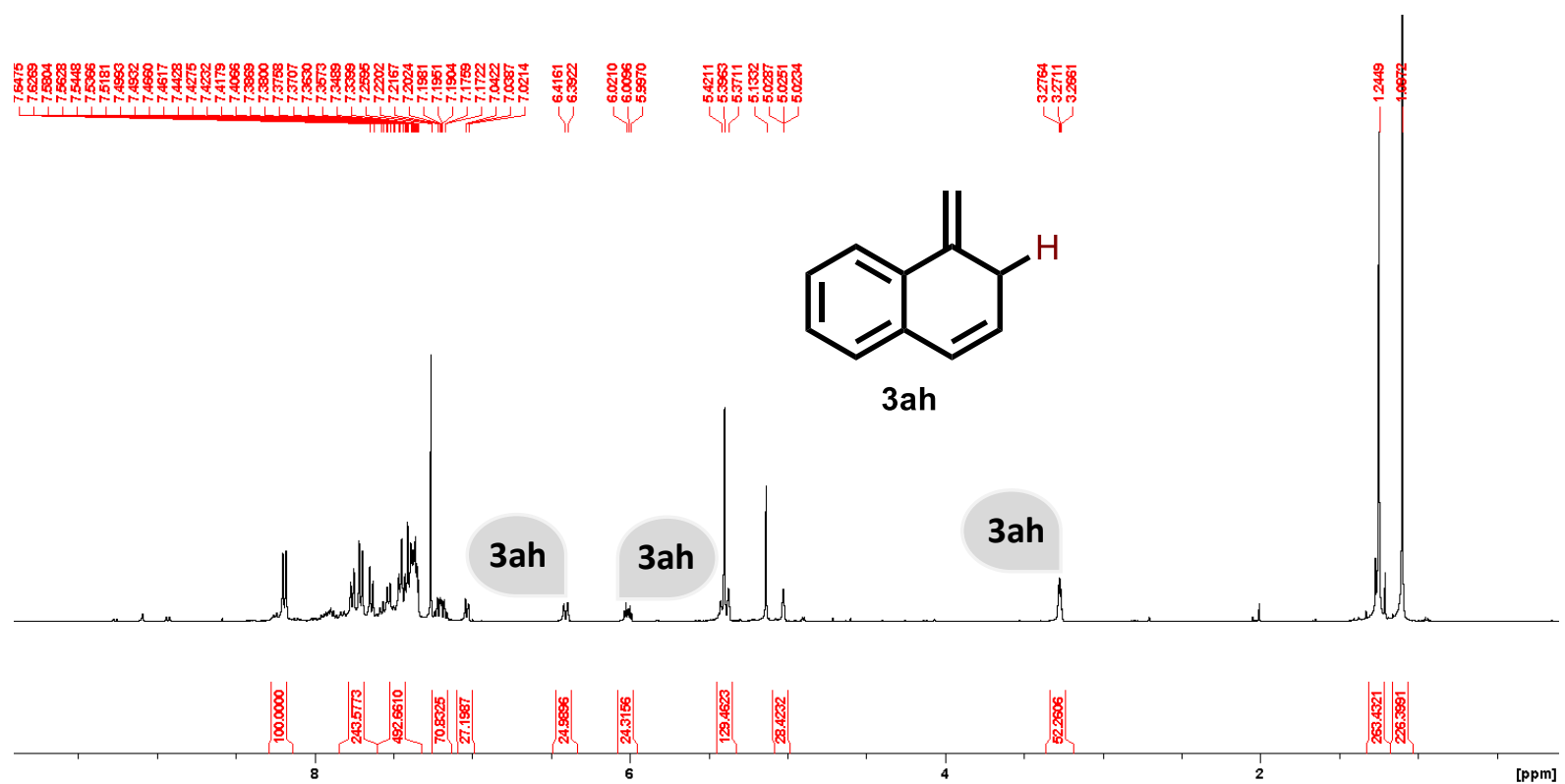


\section{Synthesis of Starting Materials}

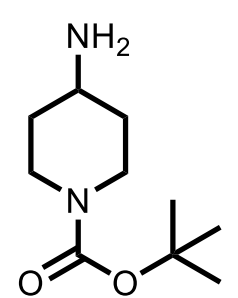

$2 z$

tert-butyl 4-aminopiperidine-1-carboxylate (2z): To a $50 \mathrm{ml}$ round bottom flask equipped with a stir bar was added $10 \mathrm{ml}$ methanol, 1-Boc-4-piperidone (500 mg, $2.41 \mathrm{mmol})$, and ammonium acetate (2.23 g, $28.9 \mathrm{mmol}, 12$ equiv.). The flask was stirred for 10 minutes at room temperature and $\mathrm{NaBH}_{3} \mathrm{CN}(606 \mathrm{mg}, 9.64$ mmol, 4 equiv.) was added in a single portion. A reflux condenser was attached to the flask and the reaction was heated at $60^{\circ} \mathrm{C}$ for 16 hours. The flask was cooled to room temperature and the volatiles were removed in vacuo. To the residue was added $30 \mathrm{ml}$ of $1 \mathrm{M}$ $\mathrm{NaOH}$ solution and the product was extracted with ethyl acetate $(6 \times 20 \mathrm{ml})$, dried over sodium sulfate and the volatiles were removed in vacuo to give the title compound in $97 \%$ yield (468 mg, 2.33 mmol). ${ }^{1} \mathbf{H}$ NMR (400 MHz, $\mathrm{CDCl}_{3}$ ): $\delta 4.09$ - 3.97 (br s, 1H), $3.74-3.64$ (m, 1H), $2.84-2.72(\mathrm{~m}, 2 \mathrm{H}), 1.87-1.73(\mathrm{~m}, 1 \mathrm{H}), 1.45(\mathrm{~s}, 9 \mathrm{H}), 1.29-1.17(\mathrm{~m}, 2 \mathrm{H})$. Spectroscopic data are in agreement with those in the literature. ${ }^{39}$

\section{Synthesis of Deuterated Amine 2d}

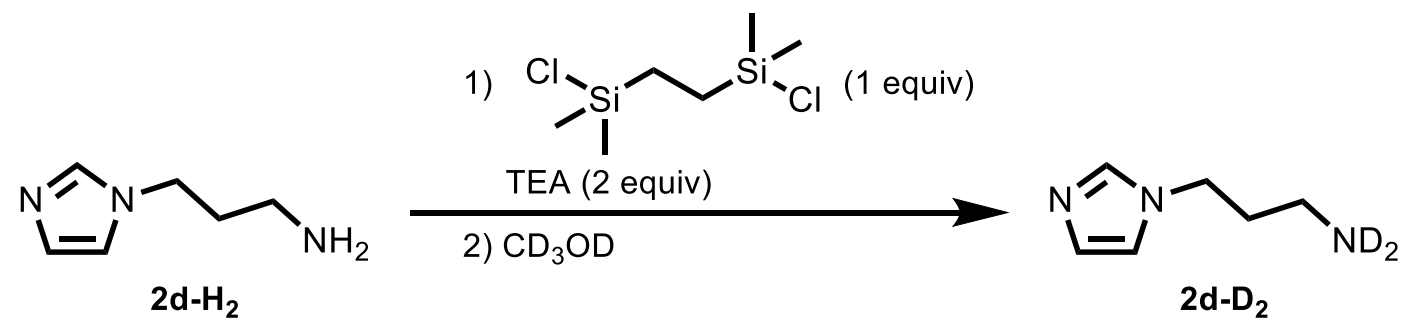

1-(3-aminopropyl) imidazole $(53.5 \mathrm{mg}, 427 \mathrm{mmol})$ was added to a vial and purged with nitrogen. The amine was dissolved in dichloromethane $(640 \mathrm{~mL})$, triethylamine $(120 \mathrm{~mL}, 2$ equiv) was added, and the mixture was cooled to $0{ }^{\circ} \mathrm{C}$. To a separate vial,1,2-Bis(chlorodimethylsilyl)ethane (92 $\mathrm{mg}, 1$ equiv) was added and purged with nitrogen. The silane was dissolved in dichloromethane $(850 \mathrm{~mL})$ and the solution was added dropwise to the reaction. The reaction stirred for 2 hours at room temperature then diethyl ether was added and the mixture was filtered. The filtrate was concentrated in vacuo then dissolved in $\mathrm{CD}_{3} \mathrm{OD}$ and stirred overnight in a capped vial at $40{ }^{\circ} \mathrm{C}$. The methanol was removed in vacuo and the deuterated amine was stored under nitrogen and used without further purification. 
${ }^{1} \mathrm{H}$ NMR Spectrum of 3-(1H-imidazol-1-yl)propan-1-amine $\left(2 \mathrm{~d}-\mathrm{H}_{2}\right)$ in CDCl3, $400 \mathrm{MHz}$ :

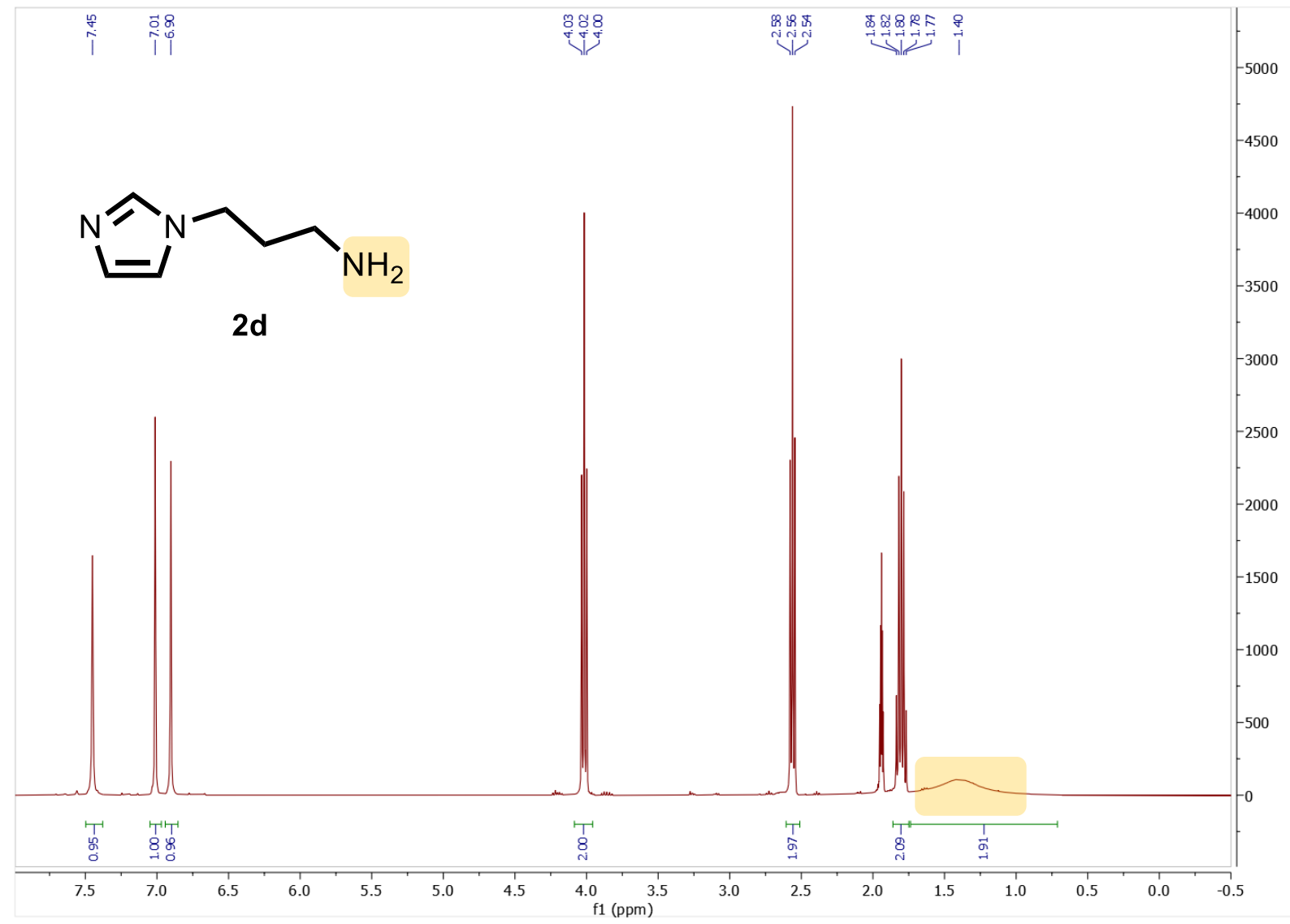


${ }^{1} \mathrm{H}$ NMR Spectrum of 3-(1H-imidazol-1-yl)propan-1-amine (2d-D $)$ in CDCl3, $400 \mathrm{MHz}$ :

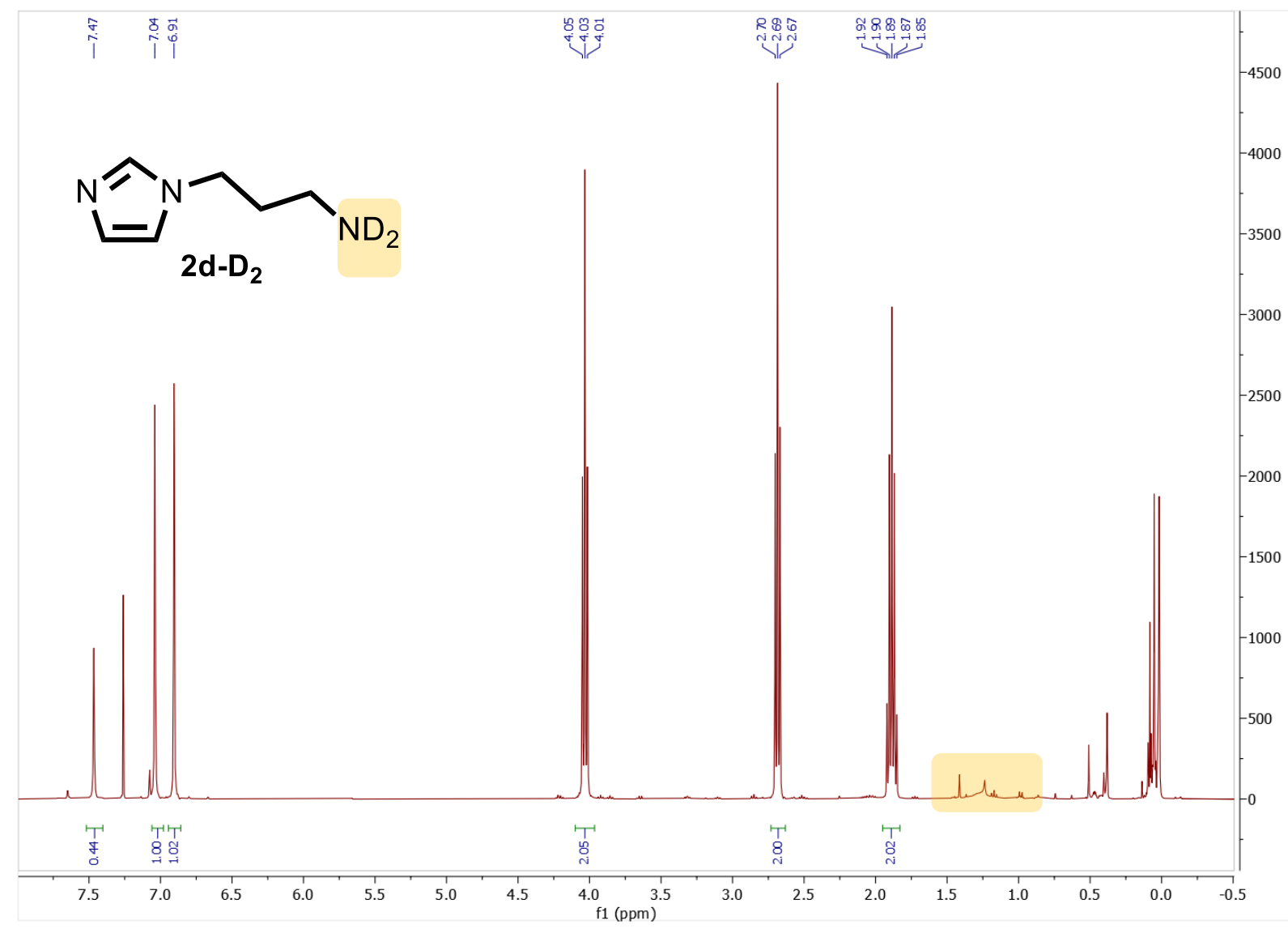




\section{DSC of Anomeric Amide}

A $4.20 \mathrm{mg}$ sample size of (1) was heated from $40{ }^{\circ} \mathrm{C}$ to $200{ }^{\circ} \mathrm{C}$ at a rate of $10{ }^{\circ} \mathrm{C} / \mathrm{min}$.

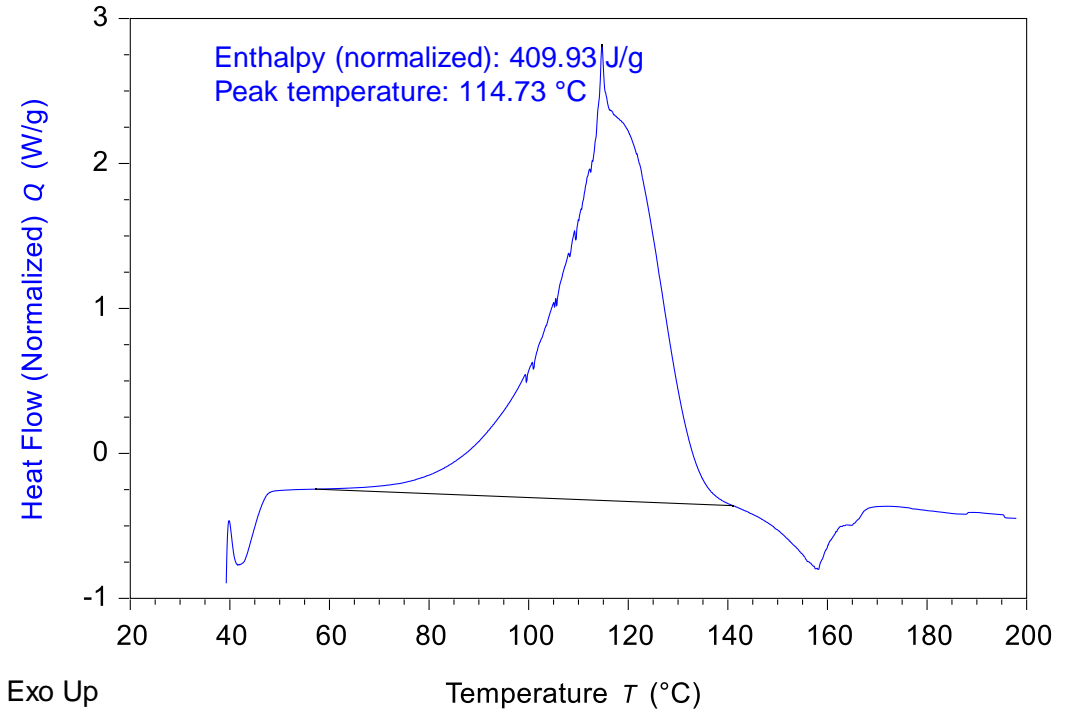




\section{Computational Methods:}

Structural optimizations were conducted at the $\mathrm{B}^{2} \mathrm{LYP}^{40}-\mathrm{D} 3^{41} / \mathrm{def} 2-\mathrm{TZVP}^{42}$ level of theory in THF solvent using the SMD implicit solvent model ${ }^{43}$ with "opt=noeigen" keyword as implemented in Gaussian 16 (version B.01) ${ }^{44}$. Frequency calculations were performed at the same level to get thermal corrections to enthalpy and Gibbs free energy (at $298 \mathrm{~K}$; noted as $H_{\text {corr }}$ and $G_{\text {corr }}$, correspondingly), and to characterize the obtained stationary points as transition states (one and only one imaginary frequency) or minima (zero imaginary frequencies). Extensive conformational search was performed for all intermediates and transition states, and only the lowest-energy species were shown and discussed. Intrinsic reaction coordinate (IRC) calculations were performed for all transition states to ensure they are connected to the corresponding intermediates. To compare energetics, we also carried out single-point energy calculations using M06-2X $\mathrm{X}^{4} / \mathrm{def} 2-\mathrm{TZVP}-\mathrm{SMD}(\mathrm{MeCN})$ and domain based local pair natural orbital coupled cluster method with single-, double-, and perturbative triple excitations ${ }^{46}$ [noted as DLPNO-CCSD(T), with def2-TZVPP basis set and def2-TZVPP/C as auxiliary basis set] with ORCA (version 4.1.1). ${ }^{47}$ All structural figures were generated using CYLview. ${ }^{48}$

To obtain DLPNO-CCSD(T)/def2-TZVPP enthalpies and Gibbs free energies in solution, we added the solvation energies and thermal corrections from DFT calculations as shown below [noted as DLPNO$\operatorname{CCSD}(\mathrm{T}) /$ def2-TZVPP-SMD(MeCN]. In this case, solvation energies were calculated as:

$\Delta E_{\text {soln }}=E[\mathrm{M} 06-2 \mathrm{X} / \mathrm{def} 2-\mathrm{TZVP}-\mathrm{SMD}(\mathrm{MeCN})]-E[\mathrm{M} 06-2 \mathrm{X} / \mathrm{def} 2-\mathrm{TZVP}-\mathrm{gas}]$

With solvation energies computed, enthalpies and Gibbs free energies at the DLPNO-CCSD(T)/def2TZVPP-SMD $(\mathrm{MeCN})$ level of theory can be calculated as:

$H[\mathrm{DLPNO}-\mathrm{CCSD}(\mathrm{T}) /$ def2-TZVPP-SMD $(\mathrm{MeCN})]=E[\mathrm{DLPNO}-\mathrm{CCSD}(\mathrm{T}) /$ def2-TZVPP $]+\Delta E_{\text {soln }}+H_{\text {corr }}$ [B3LYP-D3/def2-TZVP-SMD(THF)]

$G[\mathrm{DLPNO}-\mathrm{CCSD}(\mathrm{T}) /$ def2-TZVPP-SMD $(\mathrm{MeCN})]=E[\mathrm{DLPNO}-\mathrm{CCSD}(\mathrm{T}) /$ def2-TZVPP $]+\Delta E_{\text {soln }}+G_{\text {corr }}$ [B3LYP-D3/def2-TZVP-SMD(THF)] 


\section{Computational Results:}

$\Delta \mathrm{H}(\Delta \mathrm{G})$

(kcal/mol; 298K)

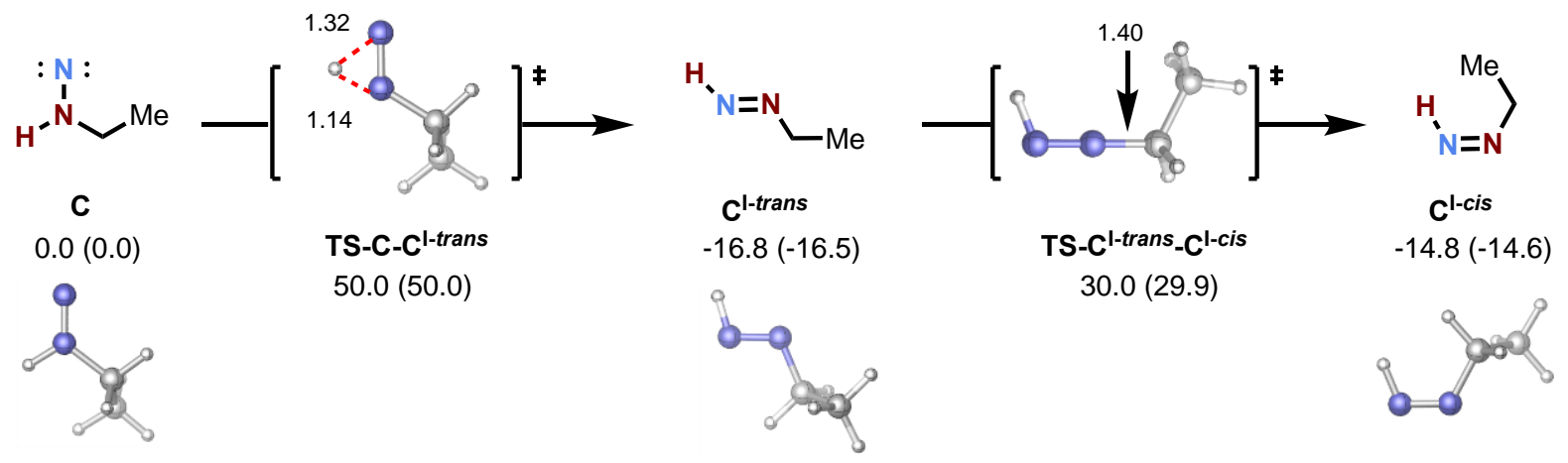

Figure S1. Energetics for the rearrangement of isodiaznes to diazenes. Enthalpies and free energies (in parenthesis) were obtained at the B3LYP-D3/def2-TZVP-SMD(THF) level of theory. 
Table S3. Benchmark of computational methods on the rearrangement of radical clock substrates.
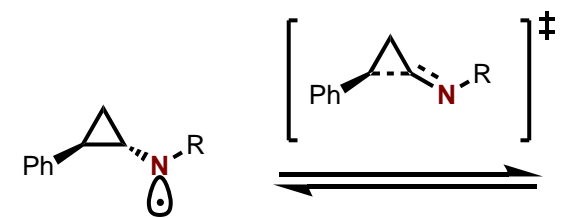<smiles>[2H]N=CCC(=O)c1ccccc1</smiles>

$\mathrm{R}=\mathrm{Me}, \mathrm{N}(\mathrm{OBn}) \mathrm{Bz}, \mathrm{N}:$

\begin{tabular}{|c|c|c|c|c|c|}
\hline Method & $\begin{array}{c}\Delta \mathrm{G}^{+} \\
(\mathrm{kcal} / \mathrm{mol})\end{array}$ & $\begin{array}{c}\Delta \mathbf{G} \\
(\mathbf{k c a l} / \mathbf{m o l})\end{array}$ & $\begin{array}{c}\text { Computed rate } \\
\qquad\left(s^{-1}\right)\end{array}$ & $\begin{array}{l}\text { Experimental } \\
\quad \operatorname{rate}\left(s^{-1}\right)\end{array}$ & $\begin{array}{c}\text { Experimental } \\
\text { barrier }(\mathrm{kcal} / \mathrm{mol})\end{array}$ \\
\hline \multicolumn{6}{|c|}{$\mathbf{R}=\mathbf{M e}$} \\
\hline M1 & 0.3 & -17.1 & $3.8 \times 10^{12}$ & \multirow[t]{4}{*}{$7 \times 10^{11}$} & \multirow[t]{4}{*}{1.3} \\
\hline M2 & 0.2 & -17.0 & $4.5 \times 10^{12}$ & & \\
\hline M3 & 2.2 & -12.4 & $1.5 \times 10^{11}$ & & \\
\hline M4 & 1.0 & -16.0 & $1.2 \times 10^{12}$ & & \\
\hline \multicolumn{6}{|c|}{$\mathbf{R}=\mathbf{N}(\mathbf{O B n}) \mathbf{B z}$} \\
\hline M1 & 1.8 & -11.6 & $3.0 \times 10^{11}$ & \multirow[t]{4}{*}{ l } & \multirow[t]{4}{*}{ l } \\
\hline M2 & 1.7 & -11.6 & $3.6 \times 10^{11}$ & & \\
\hline M3 & 5.2 & -6.4 & $9.7 \times 10^{8}$ & & \\
\hline M4 & 3.3 & -10.7 & $2.4 \times 10^{10}$ & & \\
\hline \multicolumn{6}{|c|}{$\mathbf{R}=: \mathbf{N}:$} \\
\hline M1 & 18.1 & 5.8 & $3.5 \times 10^{-1}$ & \multirow[t]{4}{*}{ l } & \multirow[t]{4}{*}{ / } \\
\hline M2 & 18.1 & 6.0 & $3.5 \times 10^{-1}$ & & \\
\hline M3 & 27.0 & 14.4 & $1.1 \times 10^{-7}$ & & \\
\hline M4 & 25.9 & 11.8 & $6.7 \times 10^{-7}$ & & \\
\hline
\end{tabular}

M1 = B3LYP-D3/def2-TZVP-SMD(THF);

M2 = B3LYP-D3/def2-TZVP-SMD(MeCN)//B3LYP-D3/def2-TZVP-SMD(THF)

M3 = M06-2X/def2-TZVP-SMD(MeCN)//B3LYP-D3/def2-TZVP-SMD(THF)

M4 = DLPNO-CCSD(T)/def2-TZVP-SMD(MeCN)//B3LYP-D3/def2-TZVP-SMD(THF)

Computed rate was calculated based on the calculated barrier with Eyring equation $k=\kappa \frac{k_{B} T}{h} e^{-\frac{\Delta G^{\ddagger}}{R T}}$, where the transmission coefficient $\kappa$ was set to 1 and temperature was set as $298 \mathrm{~K}$.

Based on the computational results for the rearrangement of 2-phenylcyclopropyl-methyl-nitrenyl radical ("R = Me"), method M4 (in red, DLPNO-CCSD(T)) predicts the barrier as close as to within 0.3 $\mathrm{kcal} / \mathrm{mol}$, thus is used to analyze the model primary amine system. 


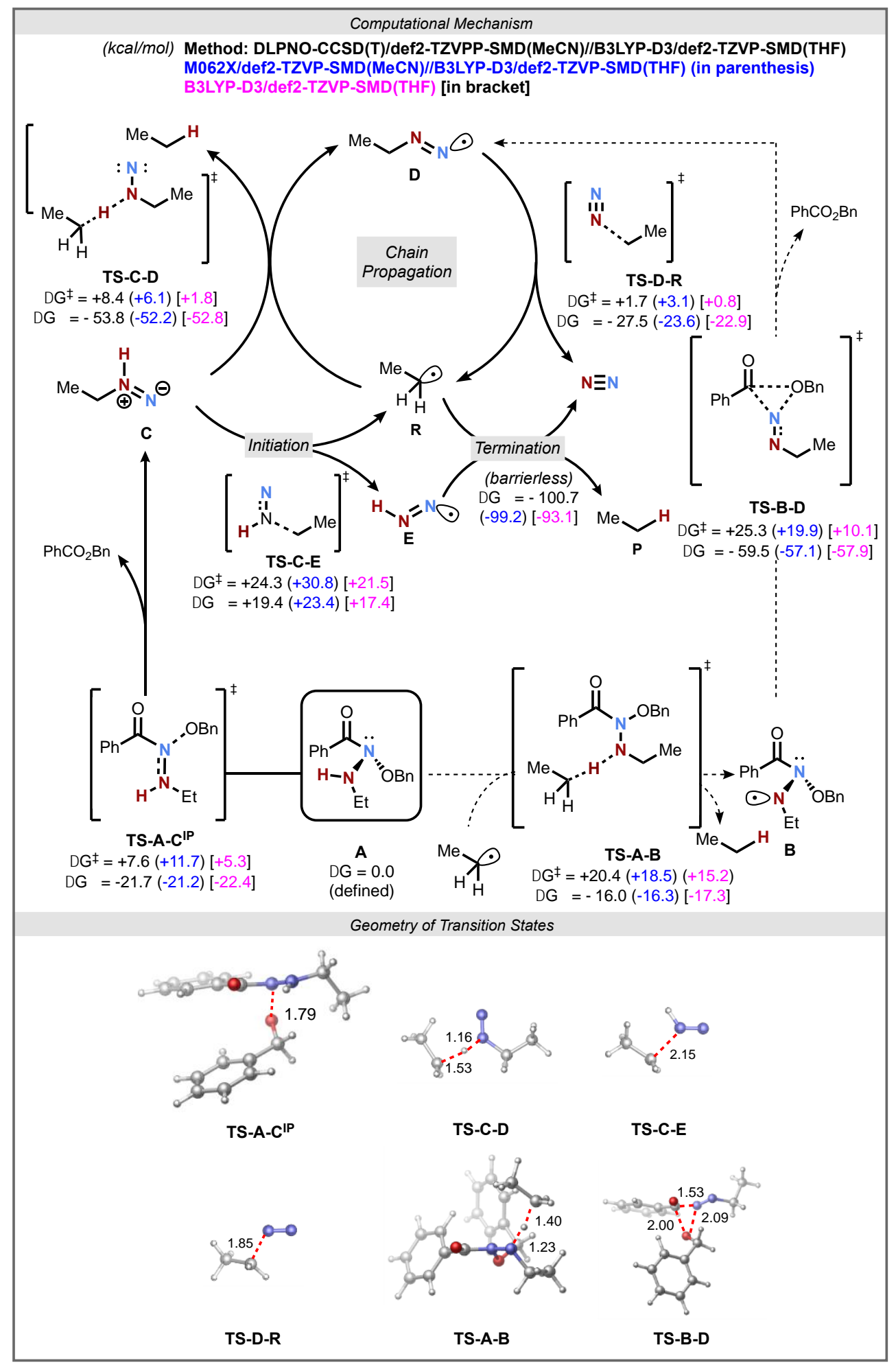

Figure S2. Energetics (Gibbs free energies) of the key processes obtained at the DLPNO-CCSD(T)/def2TZVPP-SMD(MeCN)//B3LYP-D3/def2-TZVP-SMD(THF), M06-2X/def2-TZVPSMD(MeCN)//B3LYP-D3/def2-TZVP-SMD(THF) (blue, in parenthesis) and B3LYP-D3/def2-TZVP$\mathrm{SMD}(\mathrm{THF})$ (pink, in bracket) levels of theory. 


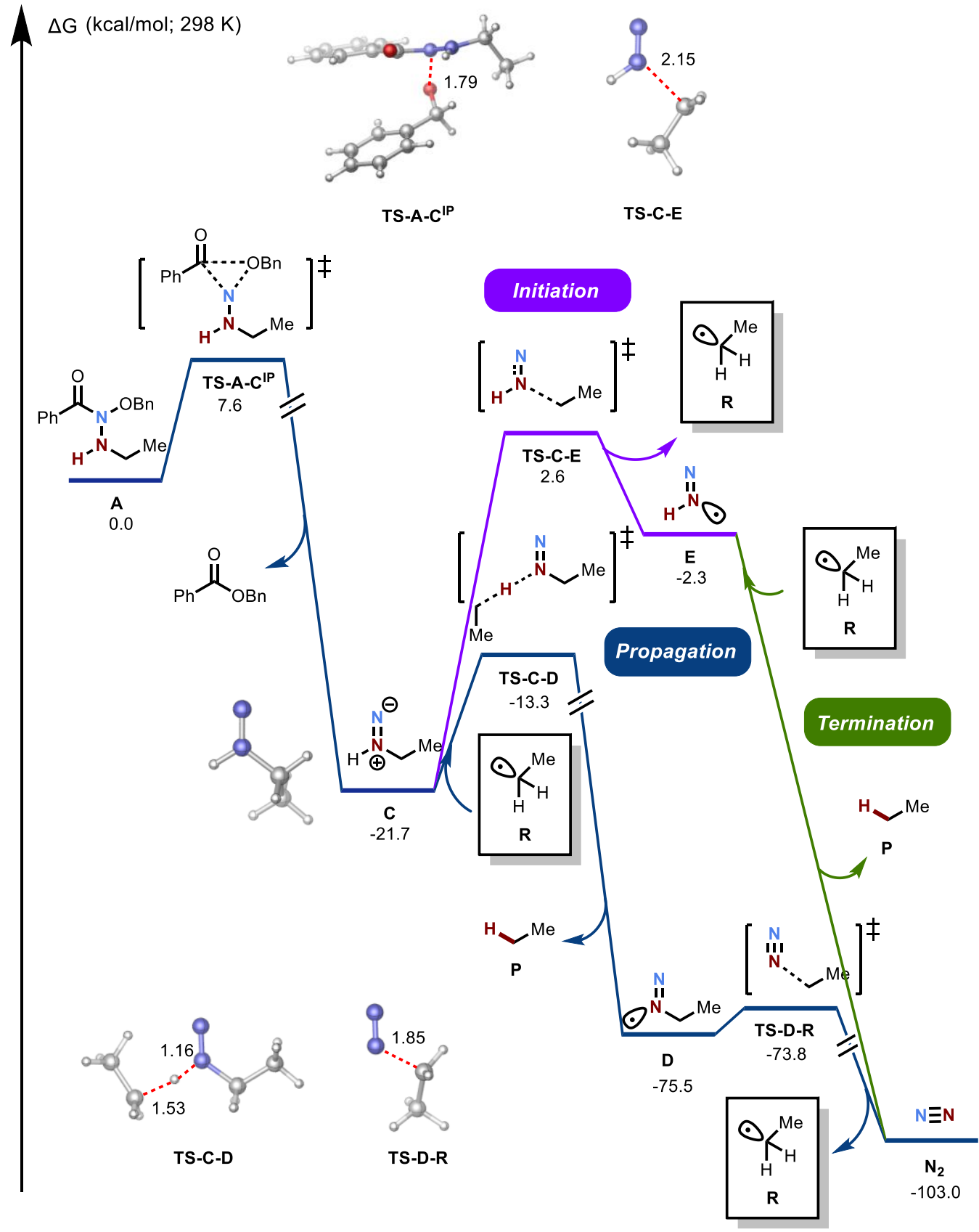

Figure S3. Major Pathways shown in Energy Profile Format 


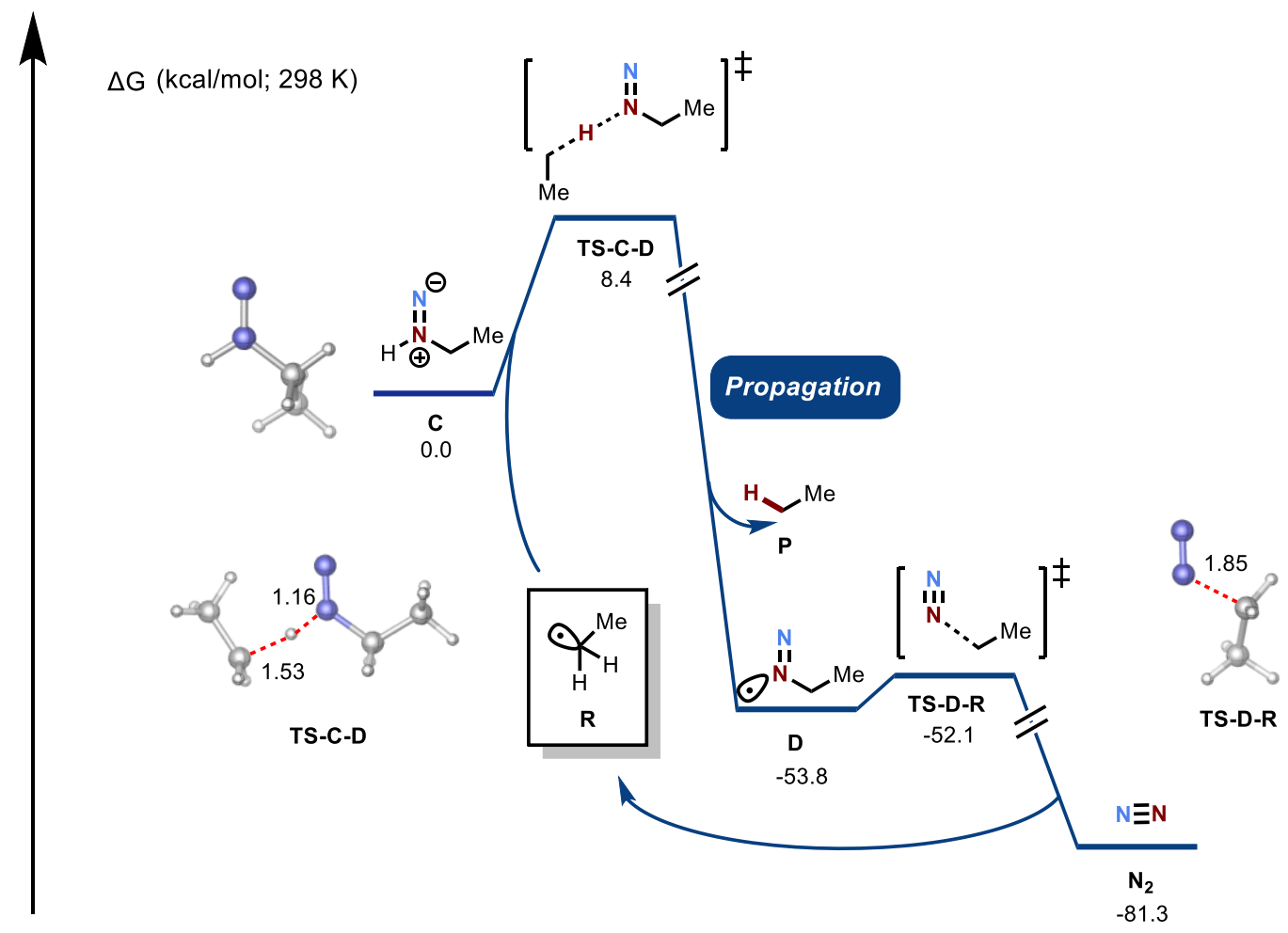

Figure S4. Propagation Cycle Referenced to Species C 


\section{References}

1. Kennedy, S. H.; Dherange, B. D.; Berger, K. J.; Levin, M. D., Skeletal editing through direct nitrogen deletion of secondary amines. Nature 2021, 593 (7858), 223-227.

2. Frost, J. W. Synthesis of caprolactam from lysine. WO/2005/123669. Dec. 29, 2005.

3. Grigan, N.; Musel, D.; Veinberg, G. A.; Lukevics, E., A Simple Preparative Method for tertButyl Protection of Aminocephalosporanic Acid. Synth. Commun. 1996, 26 (6), 1183-1185.

4. Kapoor, M.; Liu, D.; Young, M. C., Carbon Dioxide-Mediated C(sp3)-H Arylation of Amine Substrates. J. Am. Chem. Soc. 2018, 140 (22), 6818-6822.

5. Oshimoto, K.; Tsuji, H.; Kawatsura, M., Synthesis of benzoxazoles via the copper-catalyzed hydroamination of alkynones with 2-aminophenols. Org. Biomol. Chem. 2019, 17 (17), 4225-4229.

6. Chinta, B. S.; Baire, B., Formal total synthesis of selaginpulvilin D. Org. Biomol. Chem. 2017, 15 (28), 5908-5911.

7. Laaksonen, T.; Heikkinen, S.; Wähälä, K., Synthesis and applications of secondary amine derivatives of (+)-dehydroabietylamine in chiral molecular recognition. Org. Biomol. Chem. 2015, 13 (42), 10548-10555.

8. Mizar, P.; Laverny, A.; El-Sherbini, M.; Farid, U.; Brown, M.; Malmedy, F.; Wirth, T., Enantioselective Diamination with Novel Chiral Hypervalent Iodine Catalysts. Chem. Eur. J. 2014, 20 (32), 9910-9913.

9. Rodes Solanes, R. G. D., Neftali; Lopez Ortega, Beatriz; Alvarez de mon Soto, Melchor; De la Hera Martinez, Antonio; Munoz Munoz, Ana; Ledo Gomez, Francisco. Diphenyl-amine derivatives: Uses, process of synthesis and pharmaceutical compositions. WO2012069442A1. May 31, 2012.

10. Nguyen, J. D.; Reiß, B.; Dai, C.; Stephenson, C. R. J., Batch to flow deoxygenation using visible light photoredox catalysis. Chem. Commun. 2013, 49 (39), 4352-4354.

11. Cummings, S. P.; Le, T.-N.; Fernandez, G. E.; Quiambao, L. G.; Stokes, B. J., Tetrahydroxydiboron-Mediated Palladium-Catalyzed Transfer Hydrogenation and Deuteriation of Alkenes and Alkynes Using Water as the Stoichiometric H or D Atom Donor. J. Am. Chem. Soc. 2016, 138 (19), 6107-6110.

12. Borghs, J. C.; Zubar, V.; Azofra, L. M.; Sklyaruk, J.; Rueping, M., Manganese-Catalyzed Regioselective Dehydrogenative C- versus N-Alkylation Enabled by a Solvent Switch: Experiment and Computation. Org. Lett. 2020, 22 (11), 4222-4227.

13. Arai, T. M., Yasuhiro; Udagawa, Shuji;, Iseki, Katsuhiko; Izumimoto, Naoki. Cyclic amine derivatives and pharmaceutical uses thereof. WO2016/136944. Sept. 1, 2016.

14. Merkley, N.; Warkentin, J., Thermolysis of a spiro-fused oxadiazoline: The carbonyl ylide cyclic carbene diradical sequence. Can. J. Chem. 2002, 80 (9), 1187-1195. 
15. Lee, Y.; Shabbir, S.; Jeong, Y.; Ban, J.; Rhee, H., Formal Synthesis of Fesoterodine by AcidFacilitated Aromatic Alkylation. Bull. Korean Chem. Soc. 2015, 36 (12), 2885-2889.

16. Bandari, R.; Höche, T.; Prager, A.; Dirnberger, K.; Buchmeiser, M. R., Ring-Opening Metathesis Polymerization Based Pore-Size-Selective Functionalization of Glycidyl Methacrylate Based Monolithic Media: Access to Size-Stable Nanoparticles for Ligand-Free Metal Catalysis. Chem. Eur. J. 2010, 16 (15), 4650-4658.

17. Zhang, M.; Flynn, D. L.; Hanson, P. R., Oligomeric Benzylsulfonium Salts: Facile Benzylation via High-Load ROMP Reagents. J. Org. Chem. 2007, 72 (9), 3194-3198.

18. Chen, X.; Zhou, X.-Y., Decarboxylation of indole-3-carboxylic acids under metal-free conditions. Synth. Commun. 2020, 50 (6), 805-812.

19. Maazaoui, R.; Pin-Nó, M.; Gervais, K.; Abderrahim, R.; Ferreira, F.; Perez-Luna, A.; Chemla, F.; Jackowski, O., Domino Methylenation/Hydrogenation of Aldehydes and Ketones by Combining Matsubara's Reagent and Wilkinson's Catalyst. Eur. J. Org. Chem. 2016, 2016 (34), 57325737.

20. Beale, T. M.; Moon, P. J.; Taylor, M. S., Organoboron-Catalyzed Regio- and Stereoselective Formation of $\beta$-2-Deoxyglycosidic Linkages. Org. Lett. 2014, 16 (13), 3604-3607.

21. Broggi, J.; Jurčík, V.; Songis, O.; Poater, A.; Cavallo, L.; Slawin, A. M. Z.; Cazin, C. S. J., The Isolation of $[\mathrm{Pd}\{\mathrm{OC}(\mathrm{O}) \mathrm{H}\}(\mathrm{H})(\mathrm{NHC})(\mathrm{PR} 3)](\mathrm{NHC}=\mathrm{N}-$ Heterocyclic Carbene $)$ and Its Role in Alkene and Alkyne Reductions Using Formic Acid. J. Am. Chem. Soc. 2013, 135 (12), 4588-4591.

22. Porcu, S.; Rodriguez, C. A.; Frongia, A.; Secci, F., A Catalytic One-Pot Synthesis of Indolyl Cyclobutanones. Synthesis 2021, 53 (05), 925-932.

23. Ganellin, C. R.; Bishop, P. B.; Bambal, R. B.; Chan, S. M. T.; Law, J. K.; Marabout, B.; Luthra, P. M.; Moore, A. N. J.; Peschard, O.; Bourgeat, P.; Rose, C.; Vargas, F.; Schwartz, J.-C., Inhibitors of Tripeptidyl Peptidase II. 2. Generation of the First Novel Lead Inhibitor of Cholecystokinin8-Inactivating Peptidase: A Strategy for the Design of Peptidase Inhibitors. J. Med. Chem. 2000, 43 (4), 664-674.

24. Jiang, X.; Zhang, J.; Zhao, D.; Li, Y., Aldehyde effect and ligand discovery in Ru-catalyzed dehydrogenative cross-coupling of alcohols to esters. Chem. Commun. 2019, 55 (19), 2797-2800.

25. Gao, Y.; Liu, J.; Li, Z.; Guo, T.; Xu, S.; Zhu, H.; Wei, F.; Chen, S.; Gebru, H.; Guo, K., Dichloroimidazolidinedione-Activated Beckmann Rearrangement of Ketoximes for Accessing Amides and Lactams. J. Org. Chem. 2018, 83 (4), 2040-2049.

26. Mori, N.; Kuzuya, K.; Watanabe, H., Synthesis of (-)-Chamobtusin A from (+)Dehydroabietylamine. J. Org. Chem. 2016, 81 (23), 11866-11870. 
27. Li, H.; Tang, X.; Pang, J. H.; Wu, X.; Yeow, E. K. L.; Wu, J.; Chiba, S., Polysulfide Anions as Visible Light Photoredox Catalysts for Aryl Cross-Couplings. J. Am. Chem. Soc. 2021, 143 (1), 481-487.

28. Liu, Z.; Cao, S.; Yu, W.; Wu, J.; Yi, F.; Anderson, E. A.; Bi, X., Site-Selective C-H

Benzylation of Alkanes with N-Triftosylhydrazones Leading to Alkyl Aromatics. Chem 2020, 6 (8), 2110-2124.

29. Myers, A. G.; Zheng, B., New and Stereospecific Synthesis of Allenes in a Single Step from Propargylic Alcohols. J. Am. Chem. Soc. 1996, 118 (18), $4492-4493$.

30. Myers, A. G.; Zheng, B.; Movassaghi, M., Preparation of the Reagent oNitrobenzenesulfonylhydrazide. J. Org. Chem. 1997, 62 (21), 7507-7507.

31. Zhang, Y.; Torker, S.; Sigrist, M.; Bregović, N.; Dydio, P., Binuclear Pd(I)-Pd(I) Catalysis Assisted by Iodide Ligands for Selective Hydroformylation of Alkenes and Alkynes. J. Am. Chem. Soc. 2020, 142 (42), 18251-18265.

32. Natarajan, P.; Bala, A.; Mehta, S. K.; Bhasin, K. K., Visible-light photocatalyzed synthesis of 2aryl $\mathrm{N}$-methylpyrroles, furans and thiophenes utilizing arylsulfonyl chlorides as a coupling partner. Tetrahedron 2016, 72 (19), 2521-2526.

33. Liu, X.-G.; Dong, C.-S.; Li, F.; Zhang, B., Manganese-Mediated Direct Functionalization of Hantzsch Esters with Alkyl Iodides via an Aromatization-Dearomatization Strategy. Org. Lett. 2021, 23 (10), 4002-4007.

34. Rohrbach, S.; Shah, R. S.; Tuttle, T.; Murphy, J. A., Neutral Organic Super Electron Donors Made Catalytic. Angew. Chem. Int. Ed. 2019, 58 (33), 11454-11458.

35. Ye, Y.; Ma, G.; Yao, K.; Gong, H., Zn-Mediated Hydrodeoxygenation of Tertiary Alkyl Oxalates. Synlett 2020, 31, A-D.

36. Boyle, P. H.; Cocker, W.; Gordon, R. L.; Shannon, P. V. R., The chemistry of terpenes. Part XIII. Synthesis of (+)-3ß,7,7-trimethyl-anti,cis,anti-tricyclo[4,1,0,02,4]heptane and ( \pm )-trans-3-(1hydroxyethyl)-6,6-dimethylbicyclo[3,1,0]hexane, deamination products of the cis-caran-4-amines. $J$. Chem. Soc. C Org. 1971, (0), 2127-2136.

37. Benati, L.; Leardini, R.; Minozzi, M.; Nanni, D.; Scialpi, R.; Spagnolo, P.; Strazzari, S.; Zanardi, G., A Novel Tin-Free Procedure for Alkyl Radical Reactions. Angew. Chem. Int. Ed. 2004, 43 (27), 3598-3601.

38. Sugimoto, A.; Yamano, J.; Yasueda, M.; Yoneda, S., Preparation and chemical behaviour of exo-methylene compounds: isoelectronic compounds of 5-methylenecyclohexa-1,3-diene. J. Chem. Soc. Perkin Trans. I 1988, (9), 2579-2584. 
39. Chandrachud, P. P.; Wojtas, L.; Lopchuk, J. M., Decarboxylative Amination: Diazirines as Single and Double Electrophilic Nitrogen Transfer Reagents. J. Am. Chem. Soc. 2020, 142 (52), $21743-$ 21750.

40. (a) Lee, C.; Yang, W.; Parr, R. G. Development of the Colle-Salvetti Correlation-Energy Formula into a Functional of the Electron Density. Phys. Rev. B 1988, 37 (2), 785-789.

https://doi.org/10.1103/PhysRevB.37.785. (b) Becke, A. D. Density-Functional Thermochemistry. III. The Role of Exact Exchange. J. Chem. Phys. 1993, 98 (7), 5648-5652. https://doi.org/10.1063/1.464913.

41 Grimme, S.; Antony, J.; Ehrlich, S.; Krieg, H. A consistent and accurate ab initio parameterization of density functional dispersion correction (DFT-D) for the 94 elements H-Pu. J. Chem. Phys. 2010, 132 (15), 154104. https://doi.org/10.1063/1.3382344.

42. (a) Weigend, F. \& Ahlrichs, R. Balanced basis sets of split valence, triple zeta valence and quadruple zeta valence quality for $\mathrm{H}$ to Rn: Design and assessment of accuracy. Phys. Chem. Chem. Phys. 2005, 7 (18), 3297-3305. https://doi.org/10.1039/B508541A. (b) Weigend, F. Accurate Coulomb-fitting basis sets for H to Rn. Phys. Chem. Chem. Phys. 2006, 8 (9), 1057-1065. https://doi.org/10.1039/B515623H.

43. Marenich, A. V.; Cramer, C. J.; Truhlar, D. G. Universal solvation model based on solute electron density and a continuum model of the solvent defined by the bulk dielectric constant and atomic surface tensions. J. Phys. Chem. B 2009, 113 (18) 6378-6396. https://doi.org/10.1021/jp810292n.

44. Gaussian 16, Revision B.01, Frisch, M. J.; Trucks, G. W.; Schlegel, H. B.; Scuseria, G. E.; Robb, M. A.; Cheeseman, J. R.; Scalmani, G.; Barone, V.; Petersson, G. A.; Nakatsuji, H.; Li, X.; Caricato, M.; Marenich, A. V.; Bloino, J.; Janesko, B. G.; Gomperts, R.; Mennucci, B.; Hratchian, H. P.; Ortiz, J. V.; Izmaylov, A. F.; Sonnenberg, J. L.; Williams-Young, D.; Ding, F.; Lipparini, F.; Egidi, F.; Goings, J.; Peng, B.; Petrone, A.; Henderson, T.; Ranasinghe, D.; Zakrzewski, V. G.; Gao, J.; Rega, N.; Zheng, G.; Liang, W.; Hada, M.; Ehara, M.; Toyota, K.; Fukuda, R.; Hasegawa, J.; Ishida, M.; Nakajima, T.; Honda, Y.; Kitao, O.; Nakai, H.; Vreven, T.; Throssell, K.; Montgomery, J. A., Jr.; Peralta, J. E.; Ogliaro, F.; Bearpark, M. J.; Heyd, J. J.; Brothers, E. N.; Kudin, K. N.; Staroverov, V. N.; Keith, T. A.; Kobayashi, R.; Normand, J.; Raghavachari, K.; Rendell, A. P.; Burant, J. C.; Iyengar, S. S.; Tomasi, J.; Cossi, M.; Millam, J. M.; Klene, M.; Adamo, C.; Cammi, R.; Ochterski, J. W.; Martin, R. L.; Morokuma, K.; Farkas, O.; Foresman, J. B.; Fox, D. J. Gaussian, Inc., Wallingford CT, 2016.

45. Zhao, Y.; Truhlar, D. G. The M06 suite of density functionals for main group thermochemistry, thermochemical kinetics, noncovalent interactions, excited states, and transition elements: two new 
functionals and systematic testing of four M06-class functionals and 12 other functionals. Theor. Chem. Acc. 2008, 120, 215-241. https://doi.org/10.1007/s00214-007-0310-x.

46. (a) Riplinger, C.; Neese, F. An Efficient and near Linear Scaling Pair Natural Orbital Based Local Coupled Clus-ter Method. J. Chem. Phys. 2013, 138 (3), 034106. https://doi.org/10.1063/1.4773581. (b) Riplinger, C.; Pinski, P.; Becker, U.; Valeev, E. F.; Neese, F. Sparse Maps-A Systematic Infrastructure for Reduced-Scaling Electronic Structure Methods. II. Lin-ear Scaling Domain Based Pair Natural Orbital Coupled Cluster Theory. J. Chem. Phys. 2016, 144 (2), 024109. https://doi.org/10.1063/1.4939030.

47. (a) Neese, F. The ORCA program system. Wiley Interdiscip. Rev. Comput. Mol. Sci. 2012, 2 (1), 73 78. https://doi.org/10.1002/wcms.81. (b) Neese, F. Software update: the ORCA program system, version 4.0. Wiley Interdiscip. Rev. Comput. Mol. Sci. 2017, 8 (1), e1327. https://doi.org/10.1002/wcms.1327.

48. CYLview, 1.0b; Legault, C. Y., Université de Sherbrooke, 2009 (http://www.cylview.org). 


\section{NMR Spectra of New Compounds}

${ }^{1} \mathrm{H}$ NMR of tert-butyl 2-((4R,6R)-6-ethyl-2,2-dimethyl-1,3-dioxan-4-yl)acetate (3f) in CDCl3, $400 \mathrm{MHz}$ :

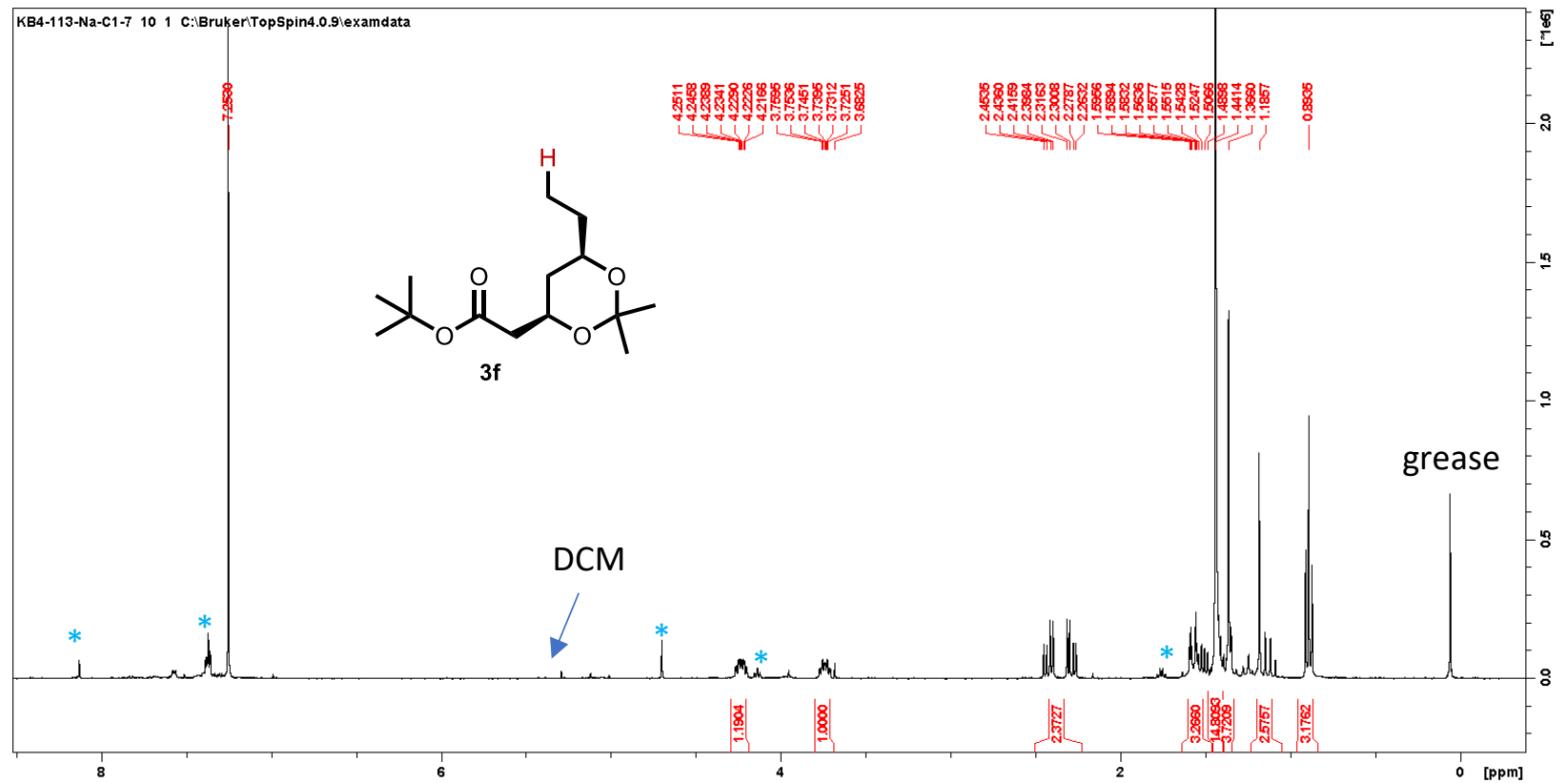

* Unidentified, coeluting impurity which could not be removed.

${ }^{13} \mathrm{C}\left\{{ }^{1} \mathrm{H}\right\}$ NMR of tert-butyl 2-((4R,6R)-6-ethyl-2,2-dimethyl-1,3-dioxan-4-yl)acetate (3f) in $\mathrm{CDCl}_{3}, 100 \mathrm{MHz}$ :

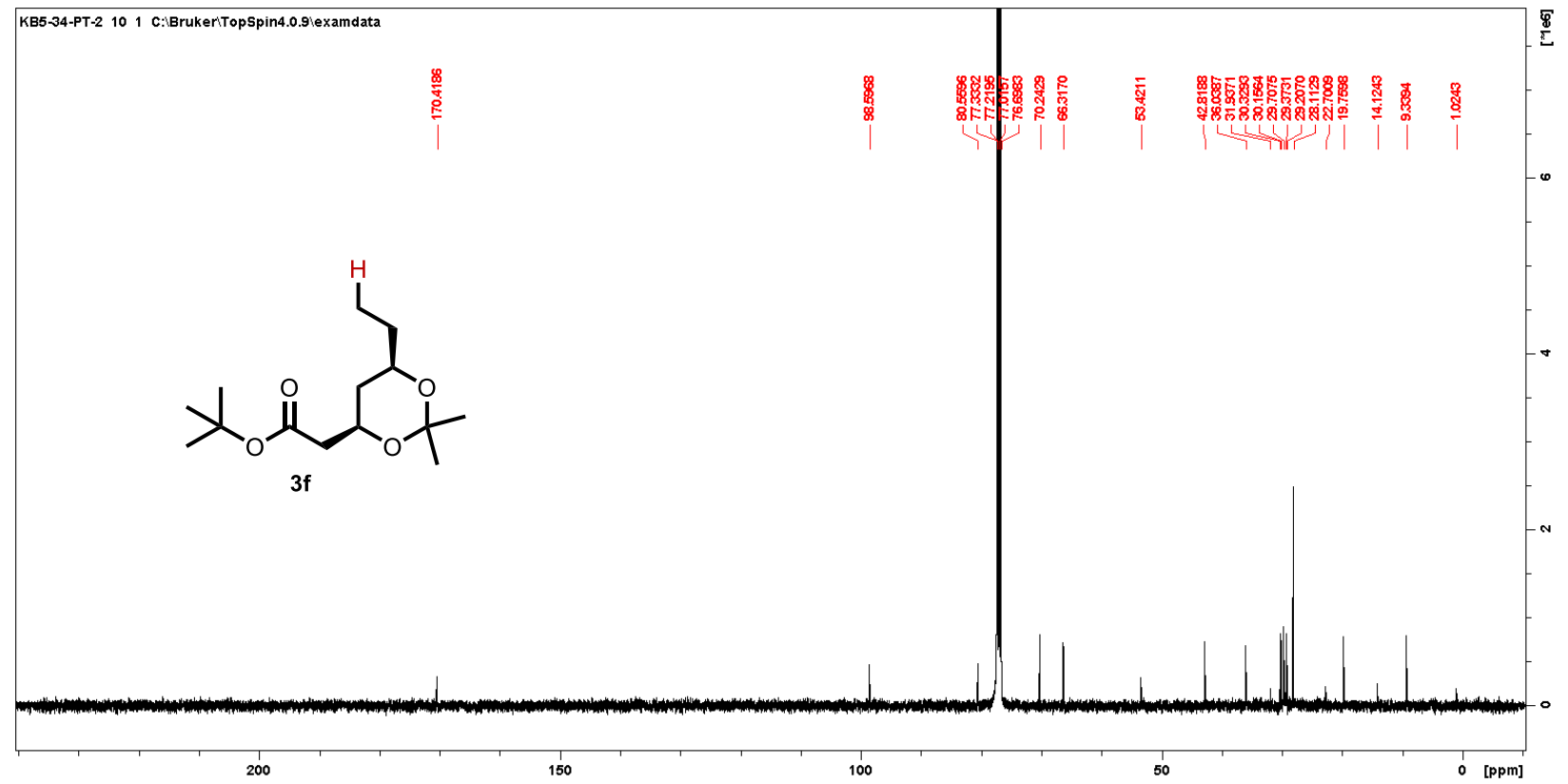


${ }^{1} \mathrm{H}$ NMR of 4-[(4-fluorophenyl)methyl]-3-methylmorpholine (3g) in $\mathrm{CDCl}_{3}, 400 \mathrm{MHz}$ :

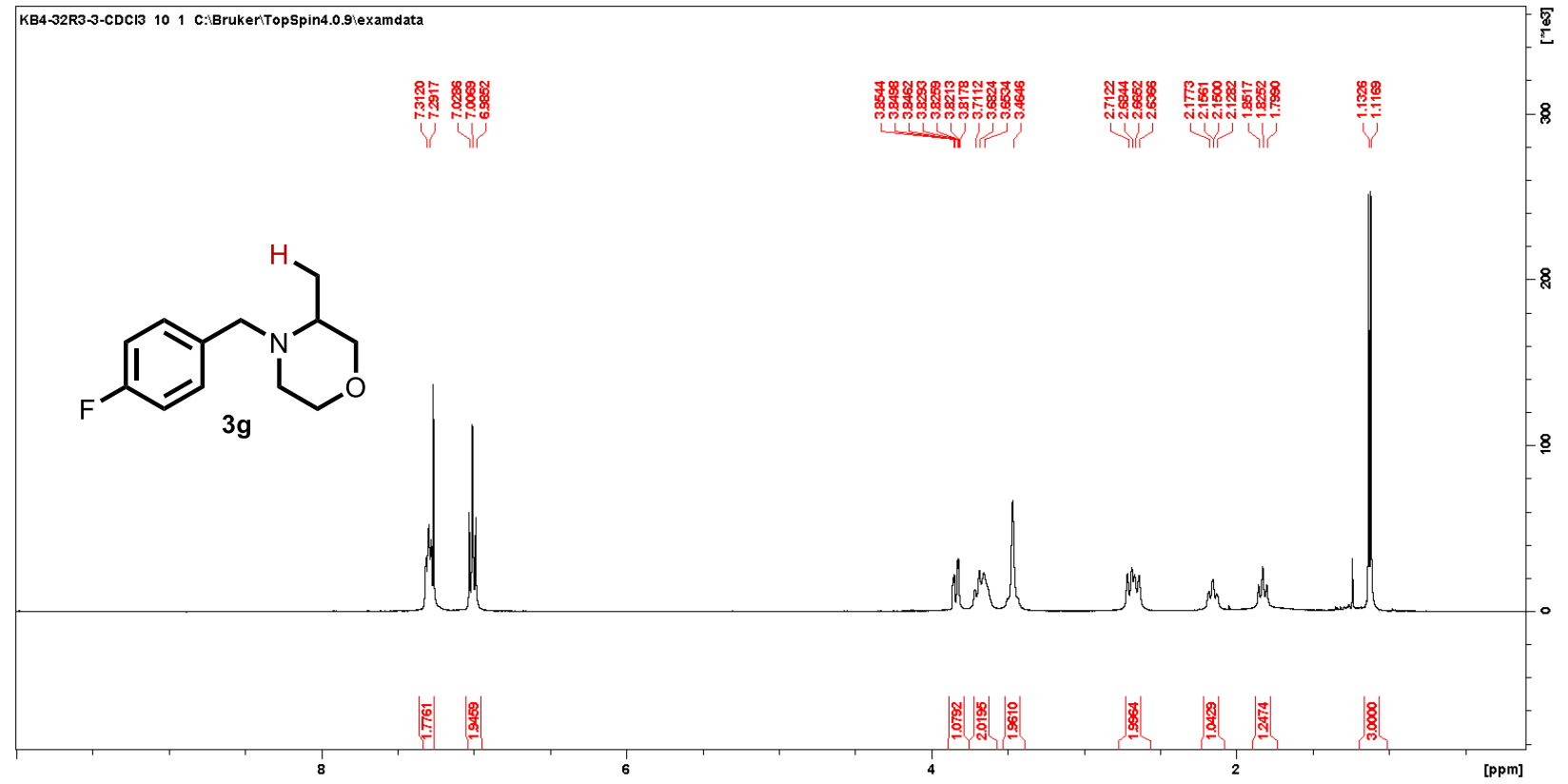

${ }^{13} \mathrm{C}\left\{{ }^{1} \mathrm{H}\right\}$ NMR of 4-[(4-fluorophenyl)methyl]-3-methylmorpholine (3g) in $\mathrm{CDCl}_{3}, 100 \mathrm{MHz}$ :

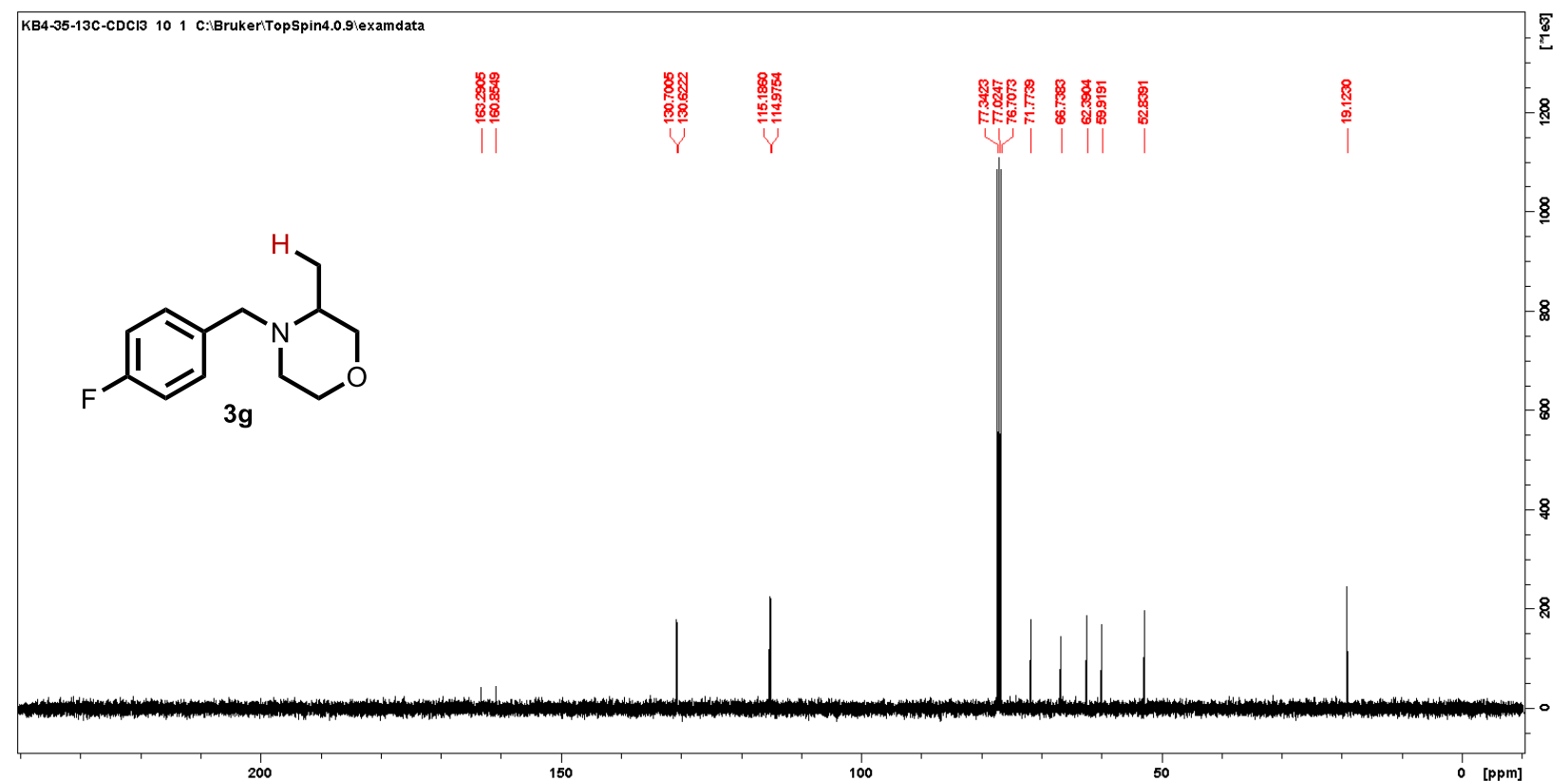


${ }^{19} \mathrm{~F}\left\{{ }^{1} \mathrm{H}\right\}$ NMR of 4-[(4-fluorophenyl)methyl]-3-methylmorpholine (3g) in $\mathrm{CDCl}_{3}, 376 \mathrm{MHz}$ :

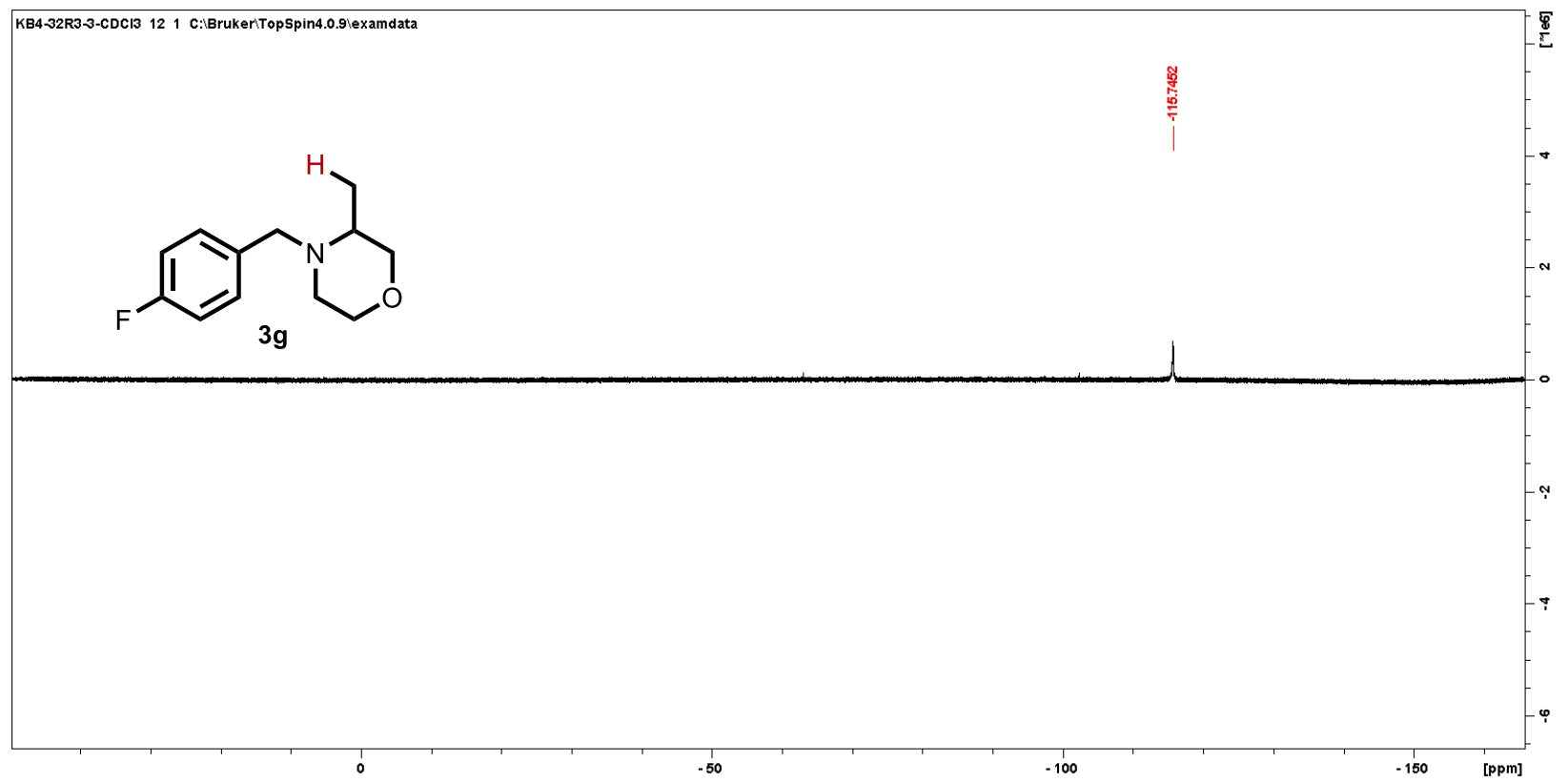

${ }^{1} \mathrm{H}$ NMR of 3-ethyl-3-phenylpiperidine-2,6-dione (3k) in $\mathrm{CDCl}_{3}, 400 \mathrm{MHz}$ :

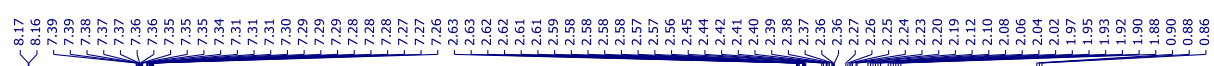<smiles>CCC1(c2ccccc2)CCC(=O)NC1=O</smiles>

3k

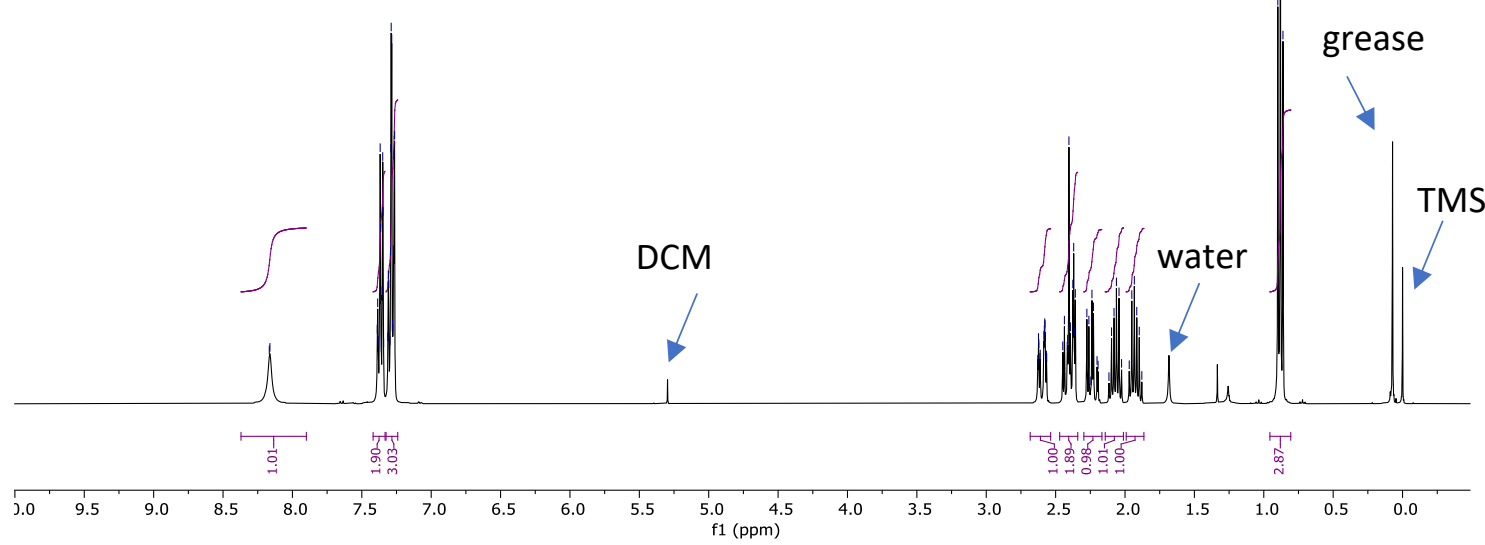


${ }^{13} \mathrm{C}\left\{{ }^{1} \mathrm{H}\right\}$ NMR of 3-ethyl-3-phenylpiperidine-2,6-dione (3k) in $\mathrm{CDCl}_{3}, 100 \mathrm{MHz}$ :
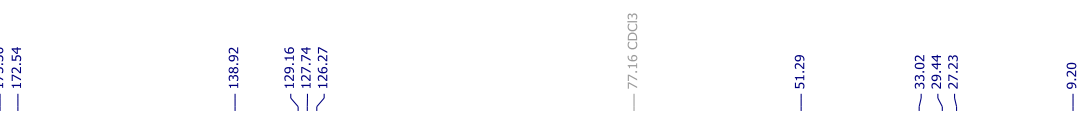<smiles>CCC1(c2ccccc2)CCC(=O)NC1=O</smiles>

3k

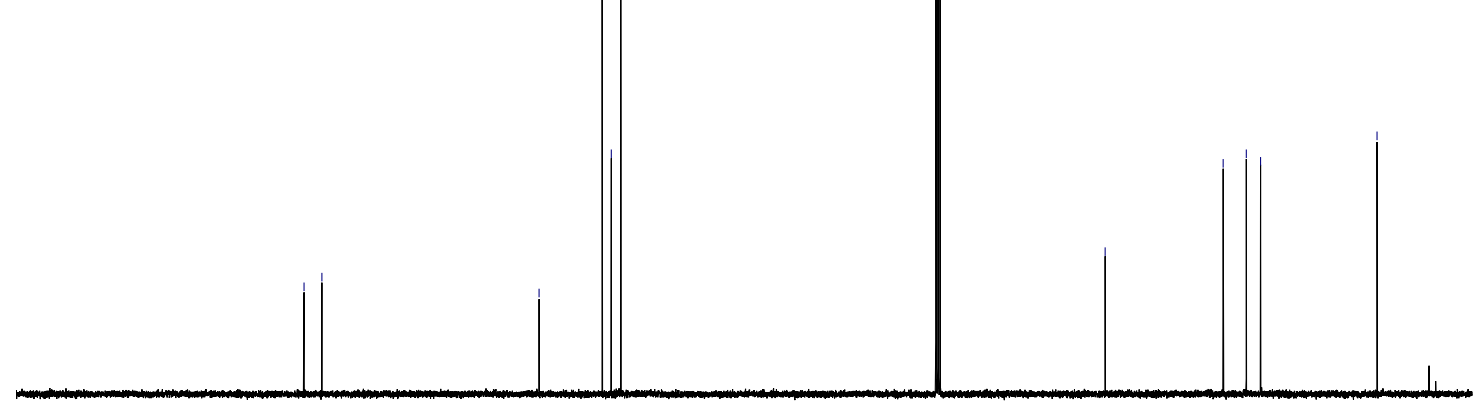

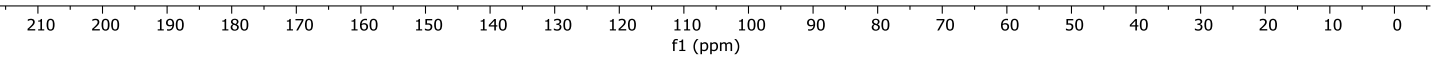

${ }^{1} \mathrm{H}$ NMR of 6-methoxy- $N$-(pentan-2-yl)quinolin-8-amine (3m) in $\mathrm{CDCl}_{3}, 400 \mathrm{MHz}$ : :B5-54-PT2 101 C:BrukerTTopSpin4.0.9lexamdata

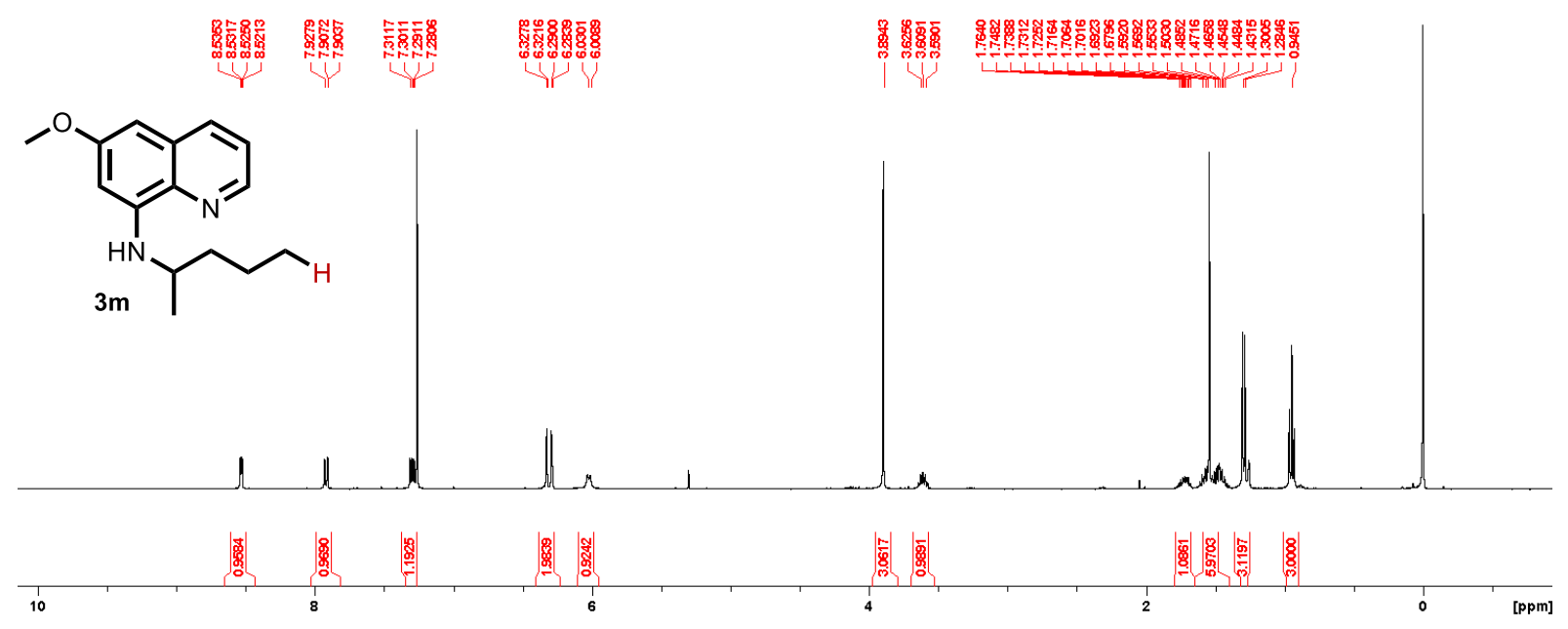


${ }^{13} \mathrm{C}\left\{{ }^{1} \mathrm{H}\right\}$ NMR of 6-methoxy- $N$-(pentan-2-yl)quinolin-8-amine (3m) in $\mathrm{CDCl}_{3}, 100 \mathrm{MHz}$ :

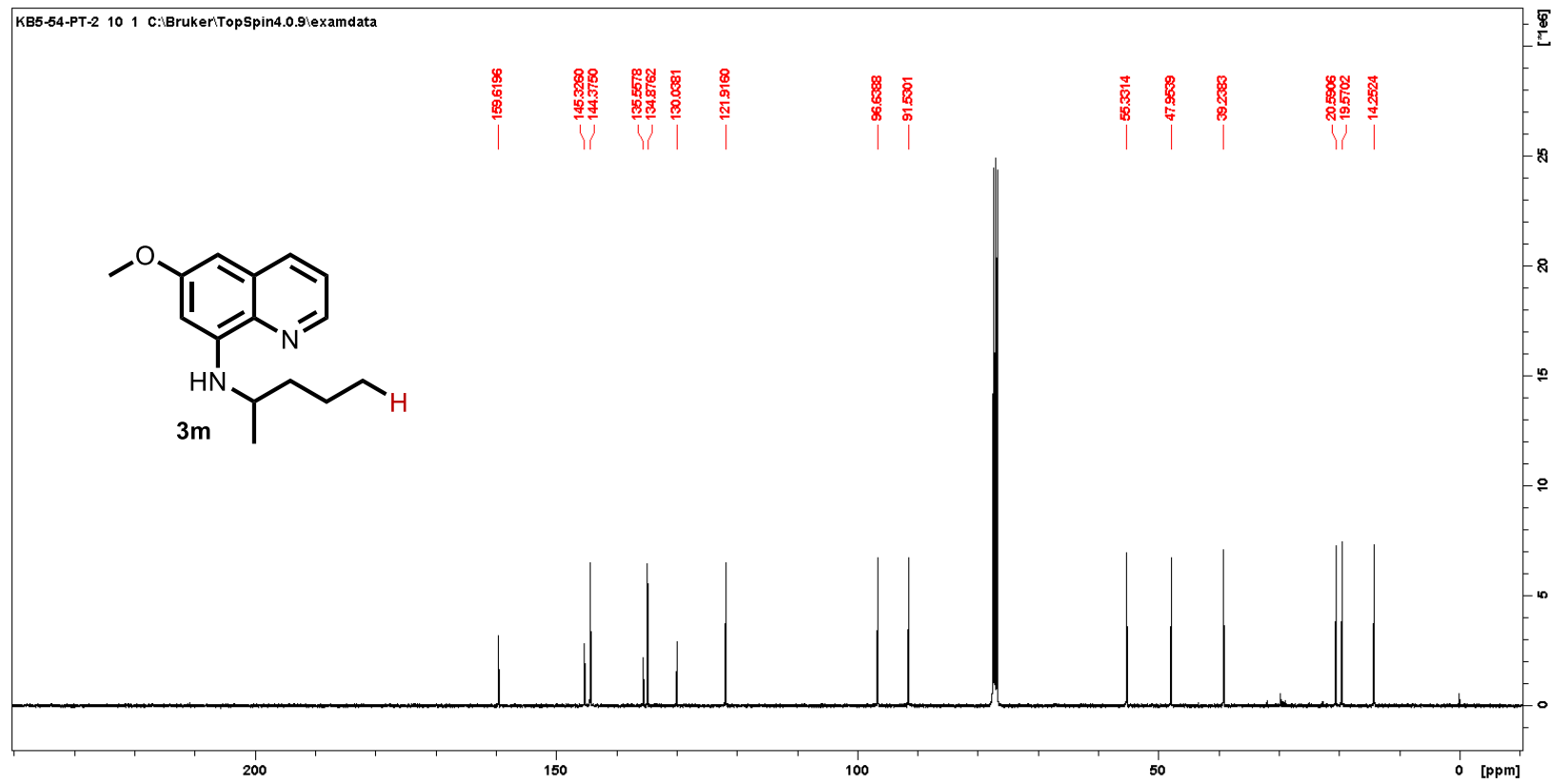

${ }^{1} \mathrm{H}$ NMR of ethyl $(3 R, 4 R)$-4-acetamido-3-(pentan-3-yloxy)cyclohex-1-ene-1-carboxylate (3n) in $\mathrm{CDCl}_{3}, 400 \mathrm{MHz}$ :

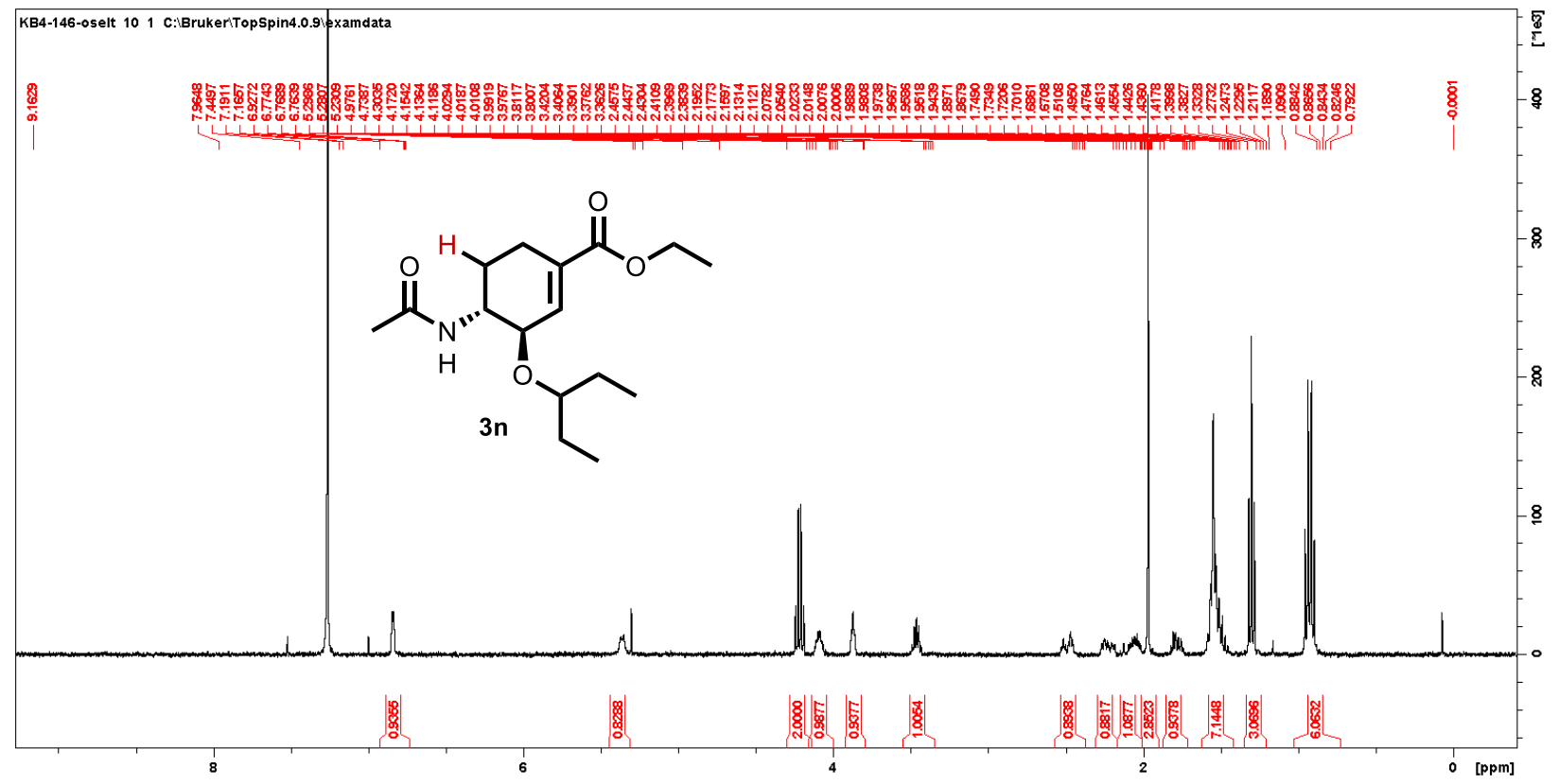


${ }^{13} \mathrm{C}\left\{{ }^{1} \mathrm{H}\right\}$ NMR of ethyl $(3 R, 4 R)$-4-acetamido-3-(pentan-3-yloxy)cyclohex-1-ene-1-carboxylate (3n) in $\mathrm{CDCl}_{3}, 100 \mathrm{MHz}$ :

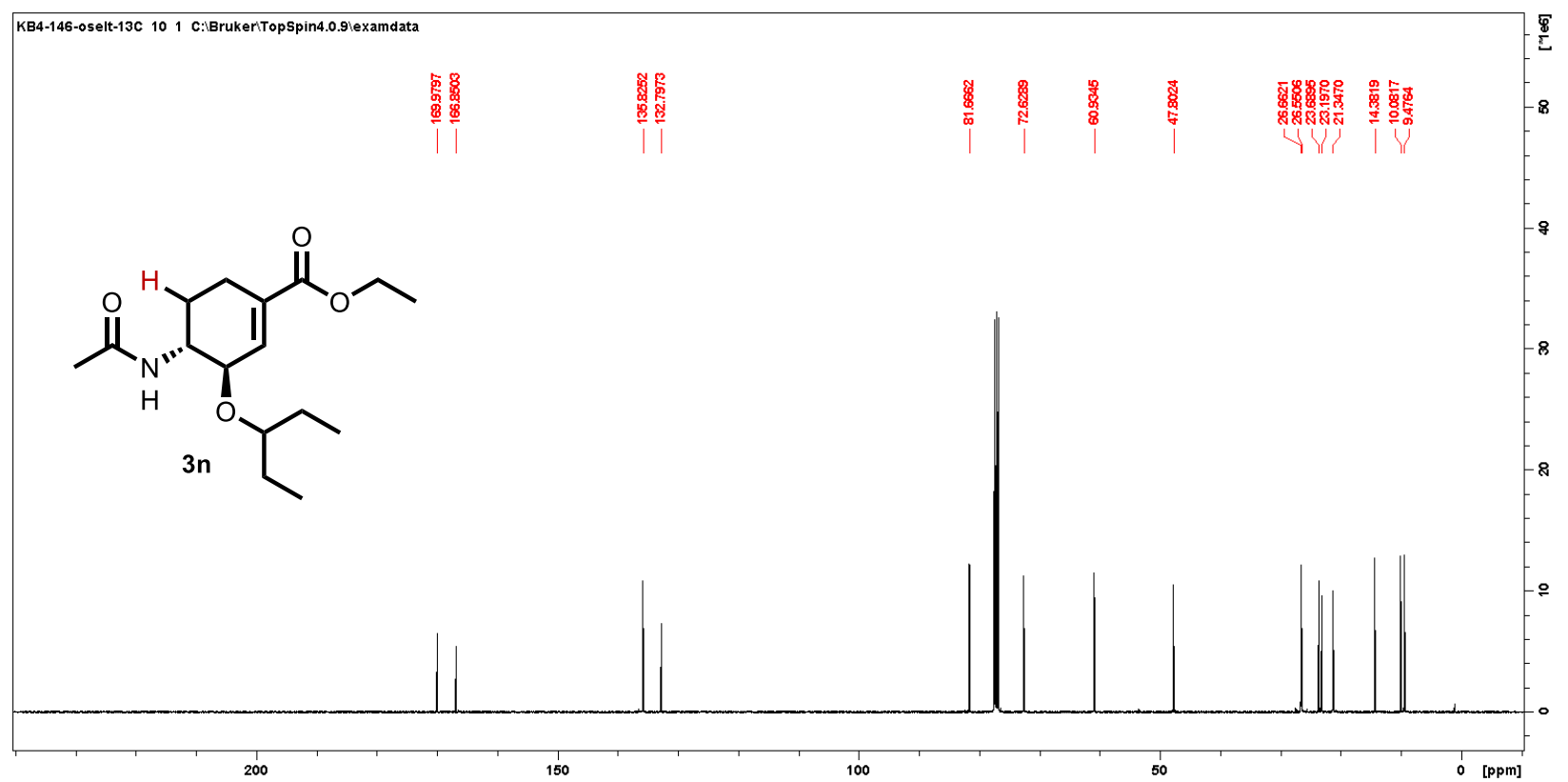

${ }^{1} \mathrm{H}$ NMR of 3-ethyl 5-methyl 4-(2-chlorophenyl)-2-(ethoxymethyl)-6-methyl-1,4dihydropyridine-3,5-dicarboxylate (3o) in $\mathrm{CDCl}_{3}, 400 \mathrm{MHz}$ :

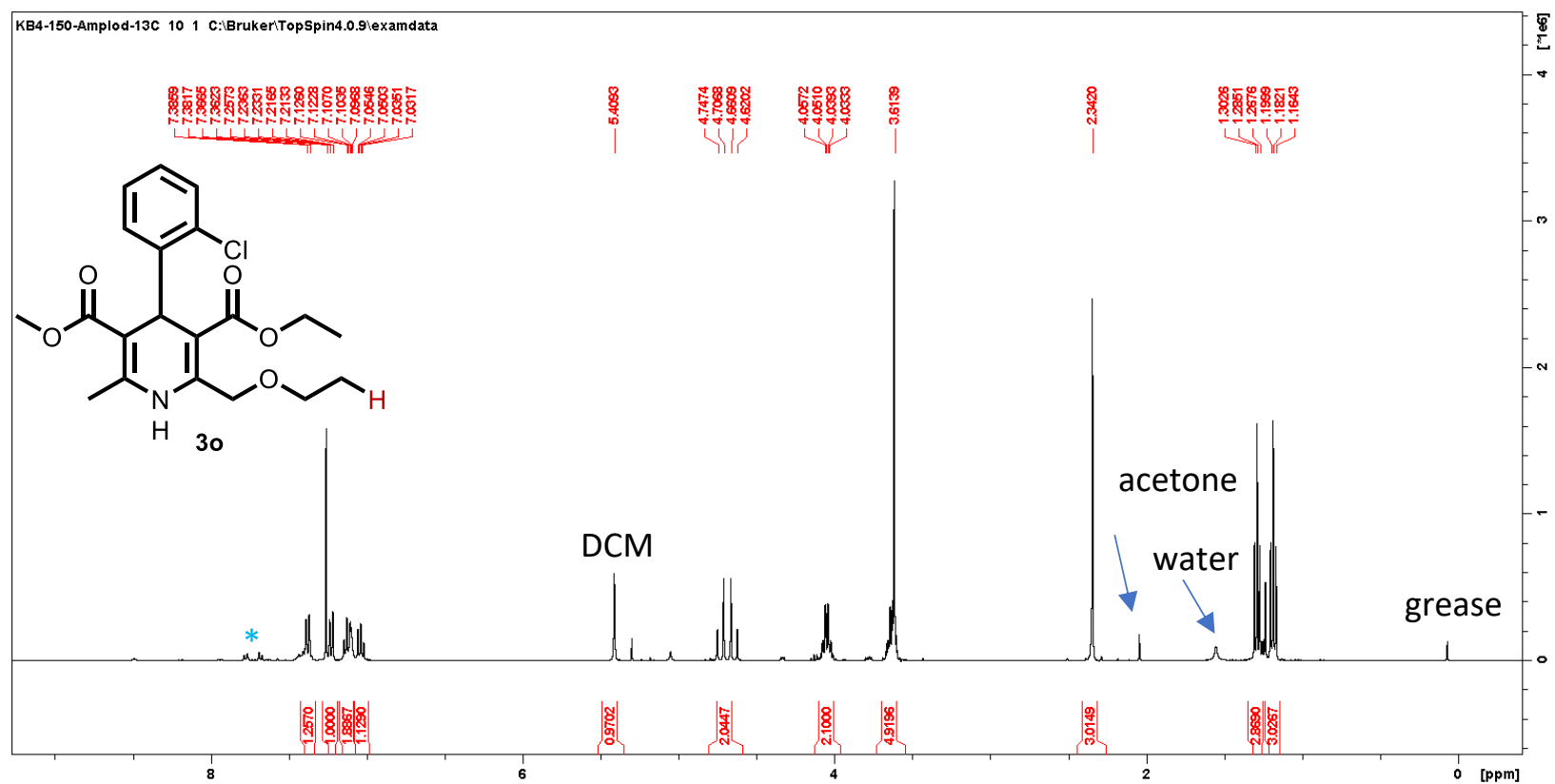

* Small quantity of coeluting $p$-trifluoromethylbenzamide. 
${ }^{13} \mathrm{C}\left\{{ }^{1} \mathrm{H}\right\}$ of 3-ethyl 5-methyl 4-(2-chlorophenyl)-2-(ethoxymethyl)-6-methyl-1,4dihydropyridine-3,5-dicarboxylate (3o) in $\mathrm{CDCl}_{3}, 100 \mathrm{MHz}$ :

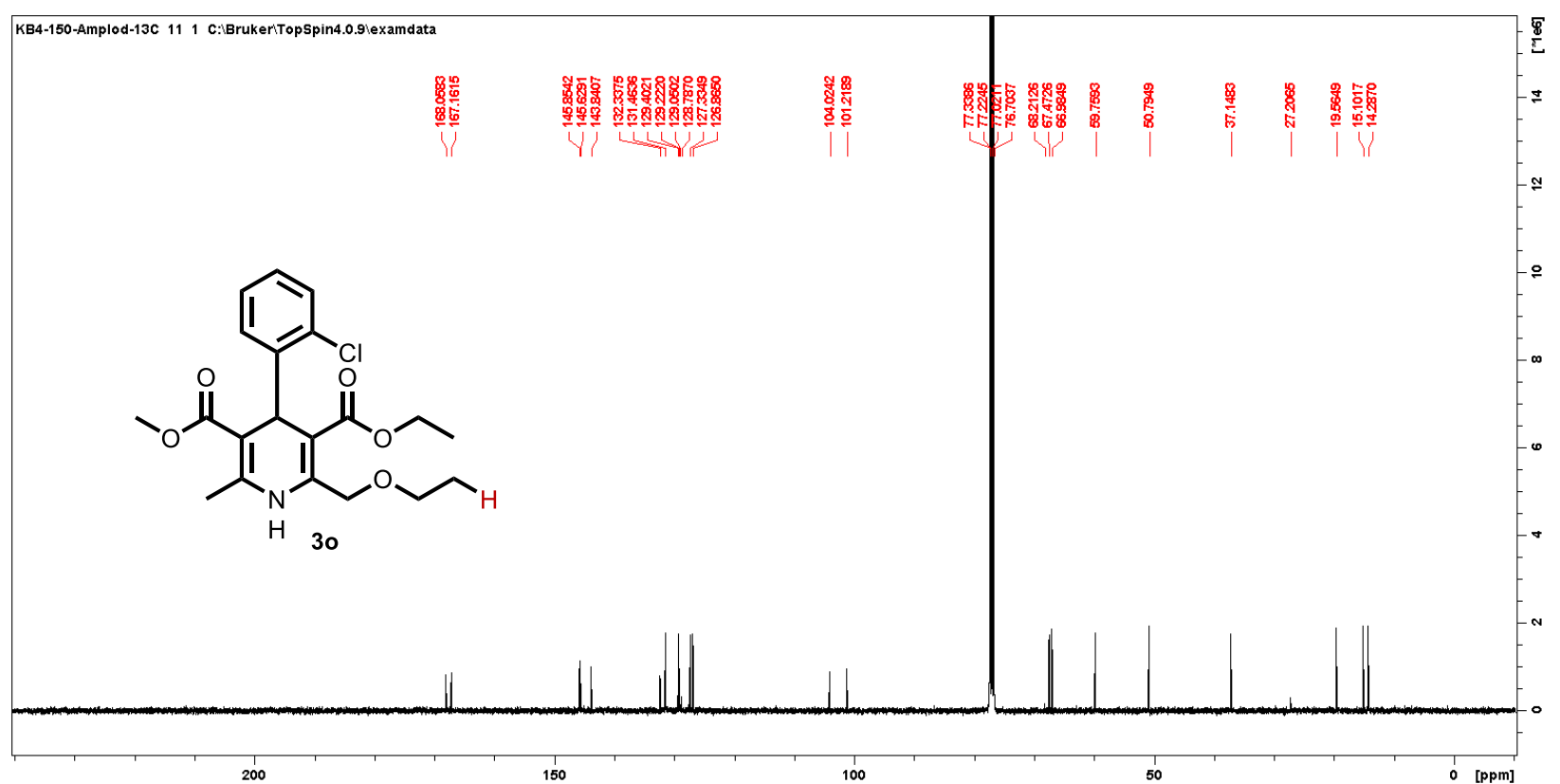

${ }^{1} \mathrm{H}$ NMR of 1-(3-(trifluoromethyl)-5,6-dihydro-[1,2,4]triazolo[4,3-a]pyrazin-7(8H)-yl-(4(2,4,5trifluorophenyl)butan-1-one (3p) in $\mathrm{CDCl}_{3}, 400 \mathrm{MHz}$ :

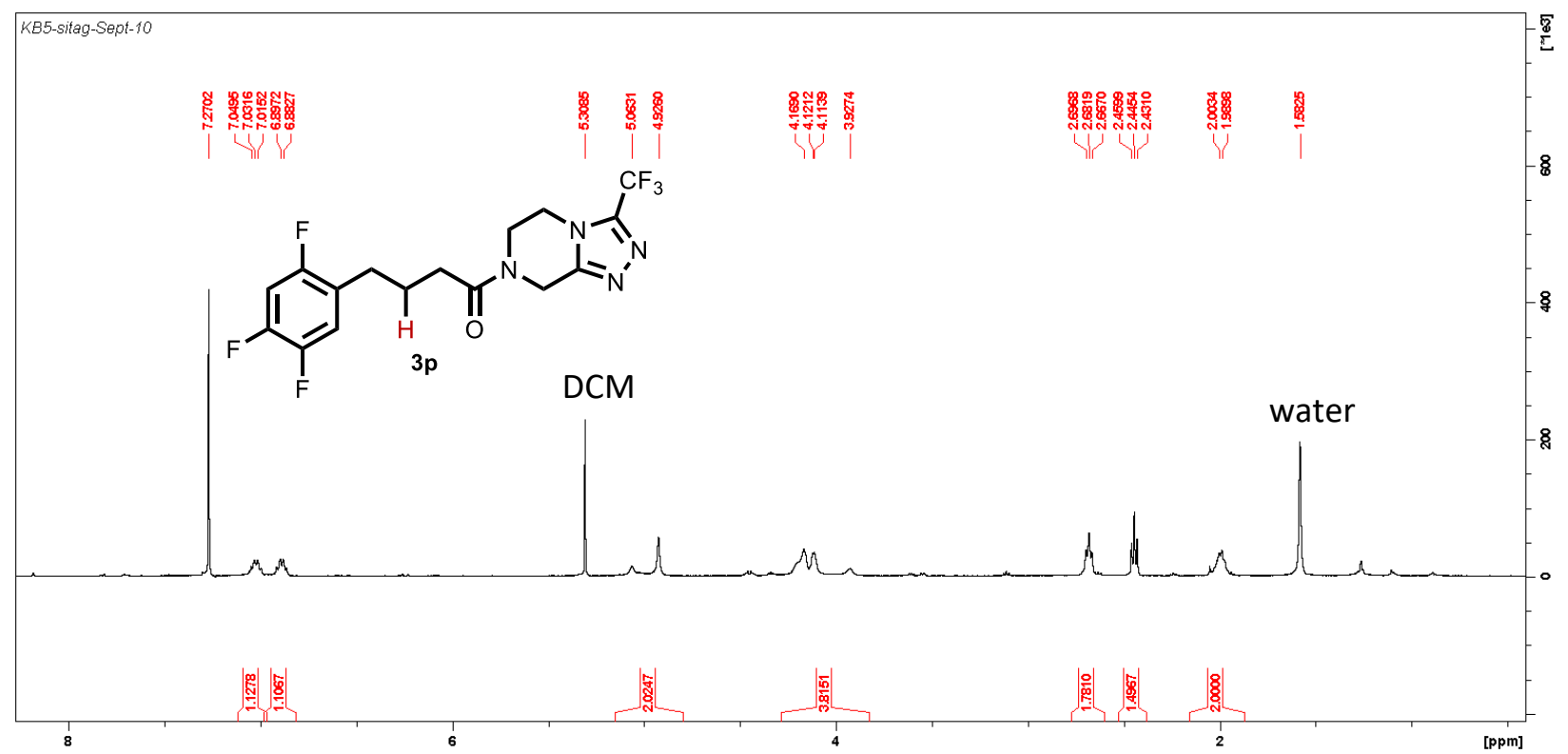


${ }^{13} \mathrm{C}\left\{{ }^{1} \mathrm{H}\right\}$ NMR of 1-(3-(trifluoromethyl)-5,6-dihydro-[1,2,4]triazolo[4,3-a]pyrazin-7(8H)-yl(4(2,4,5-trifluorophenyl)butan-1-one (3p) in $\mathrm{CDCl}_{3}, 126 \mathrm{MHz}$ :

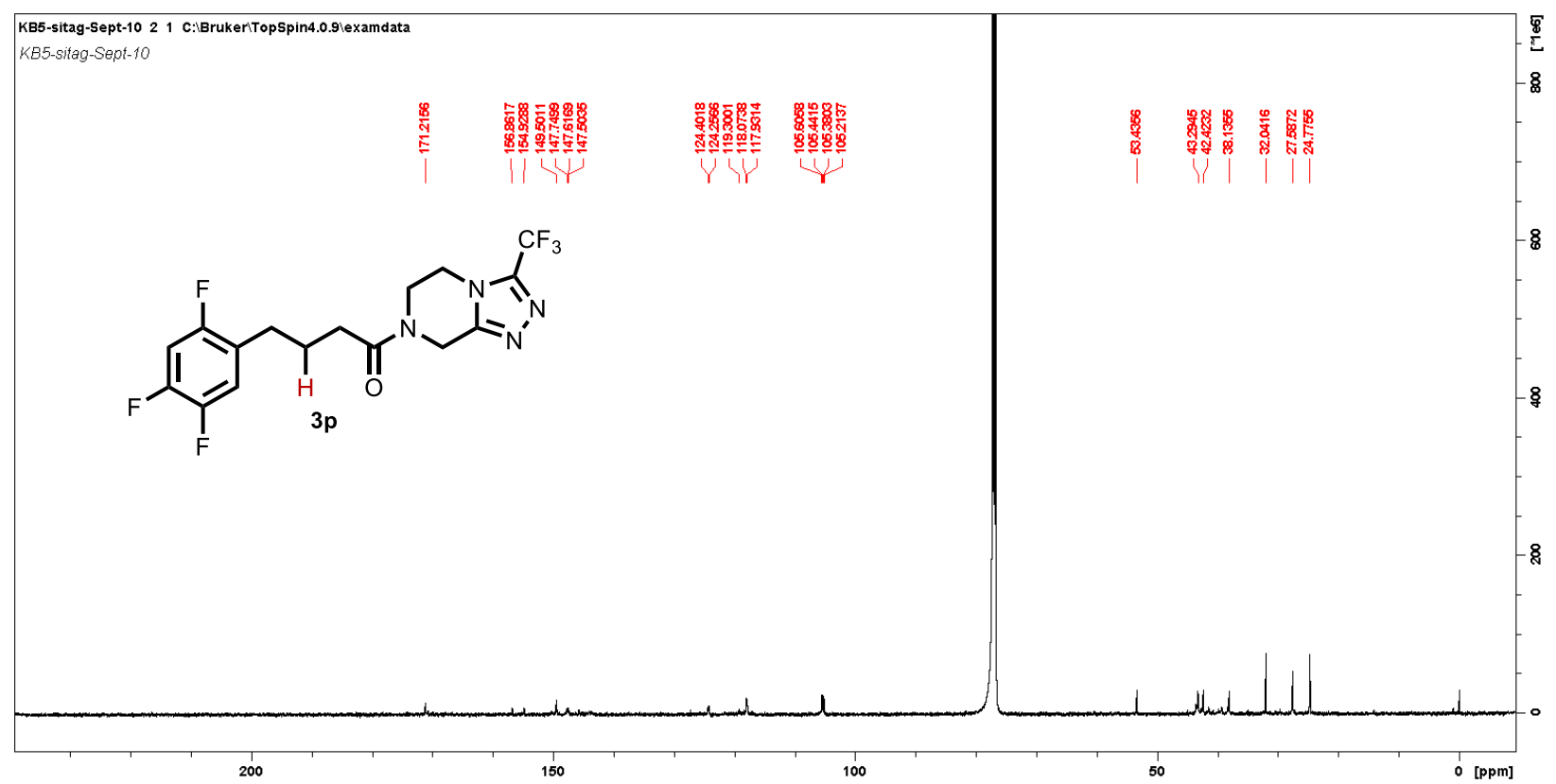

${ }^{19} \mathrm{~F}\left\{{ }^{1} \mathrm{H}\right\}$ NMR of 1-(3-(trifluoromethyl)-5,6-dihydro-[1,2,4]triazolo[4,3-a]pyrazin-7(8H)-yl(4(2,4,5-trifluorophenyl)butan-1-one (3p) in $\mathrm{CDCl}_{3}, 376 \mathrm{MHz}$ :

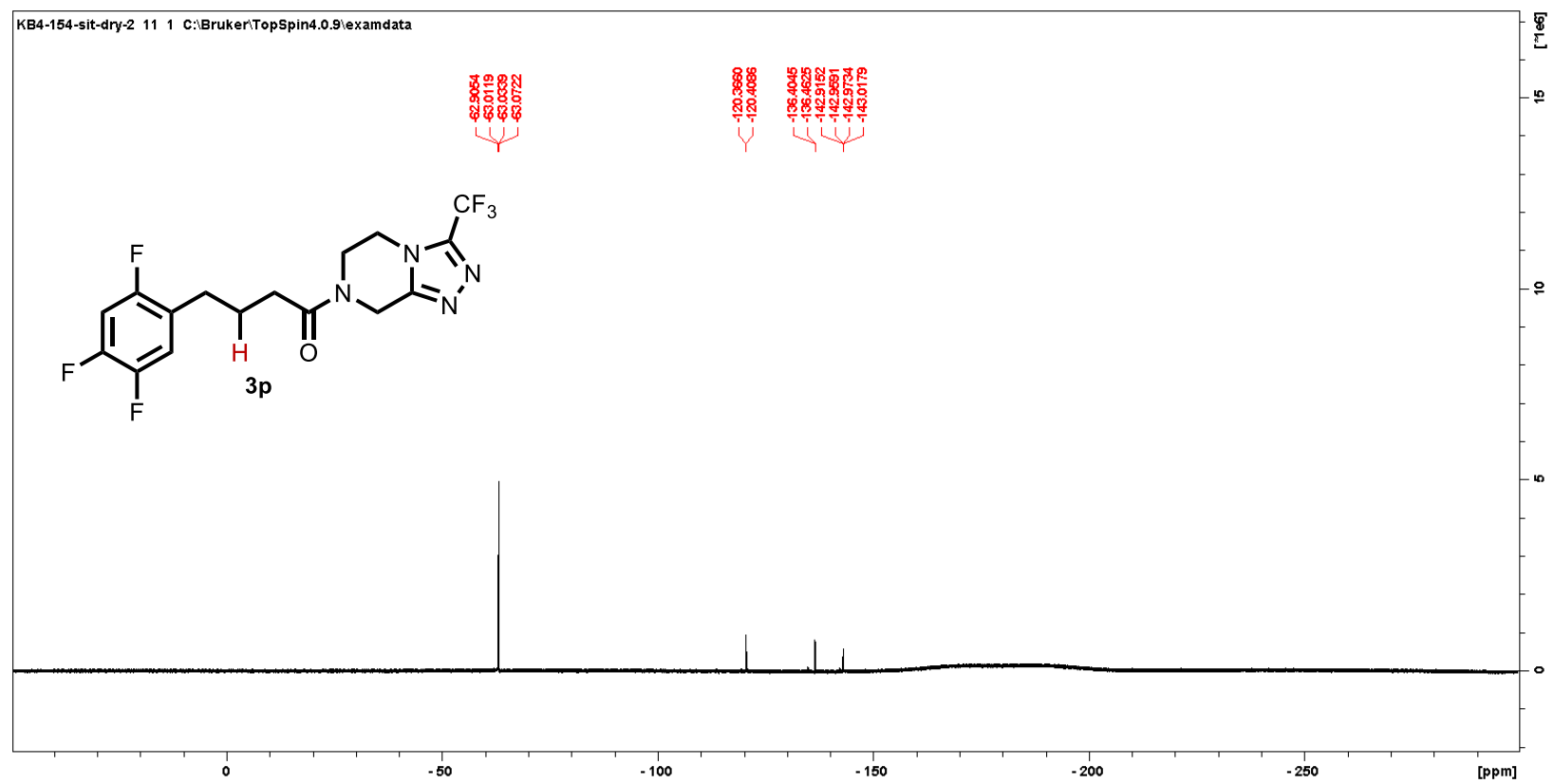


${ }^{1} \mathrm{H}$ NMR of 5-((3R,6S)-6-(2,5-difluorophenyl)tetrahydro-2H-pyran-3-yl)-2-(methylsulfonyl)2,4,5,6-tetrahydropyrrolo[3,4-c]pyrazole (3q) in $\mathrm{CDCl}_{3}, 400 \mathrm{MHz}$ :

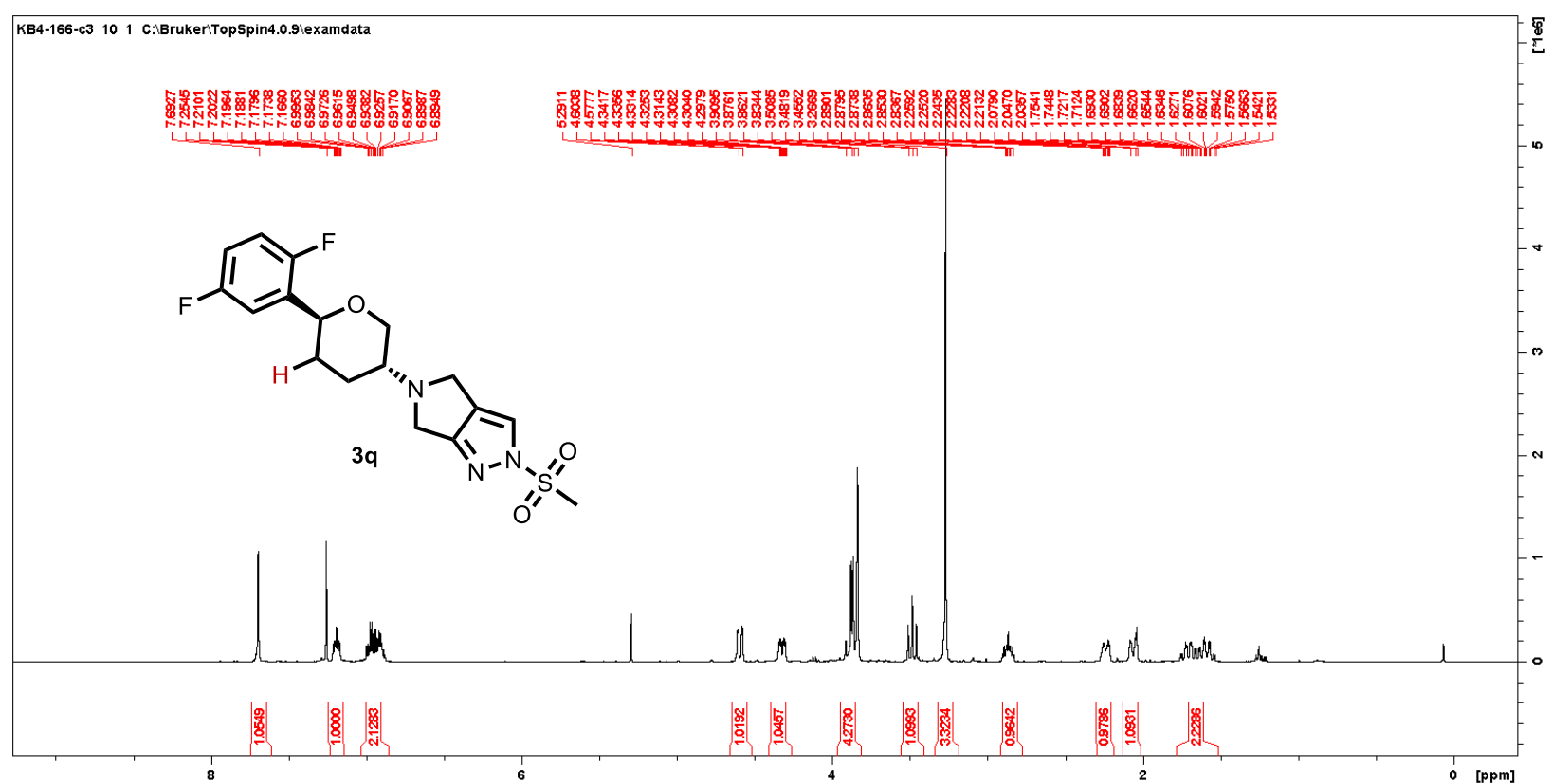

${ }^{19} \mathrm{~F}\left\{{ }^{1} \mathrm{H}\right\}$ NMR of 5-((3R,6S)-6-(2,5-difluorophenyl)tetrahydro- $2 H$-pyran-3-yl)-2(methylsulfonyl)-2,4,5,6-tetrahydropyrrolo[3,4-c]pyrazole (3q) in $\mathrm{CDCl}_{3}, 376 \mathrm{MHz}$ :

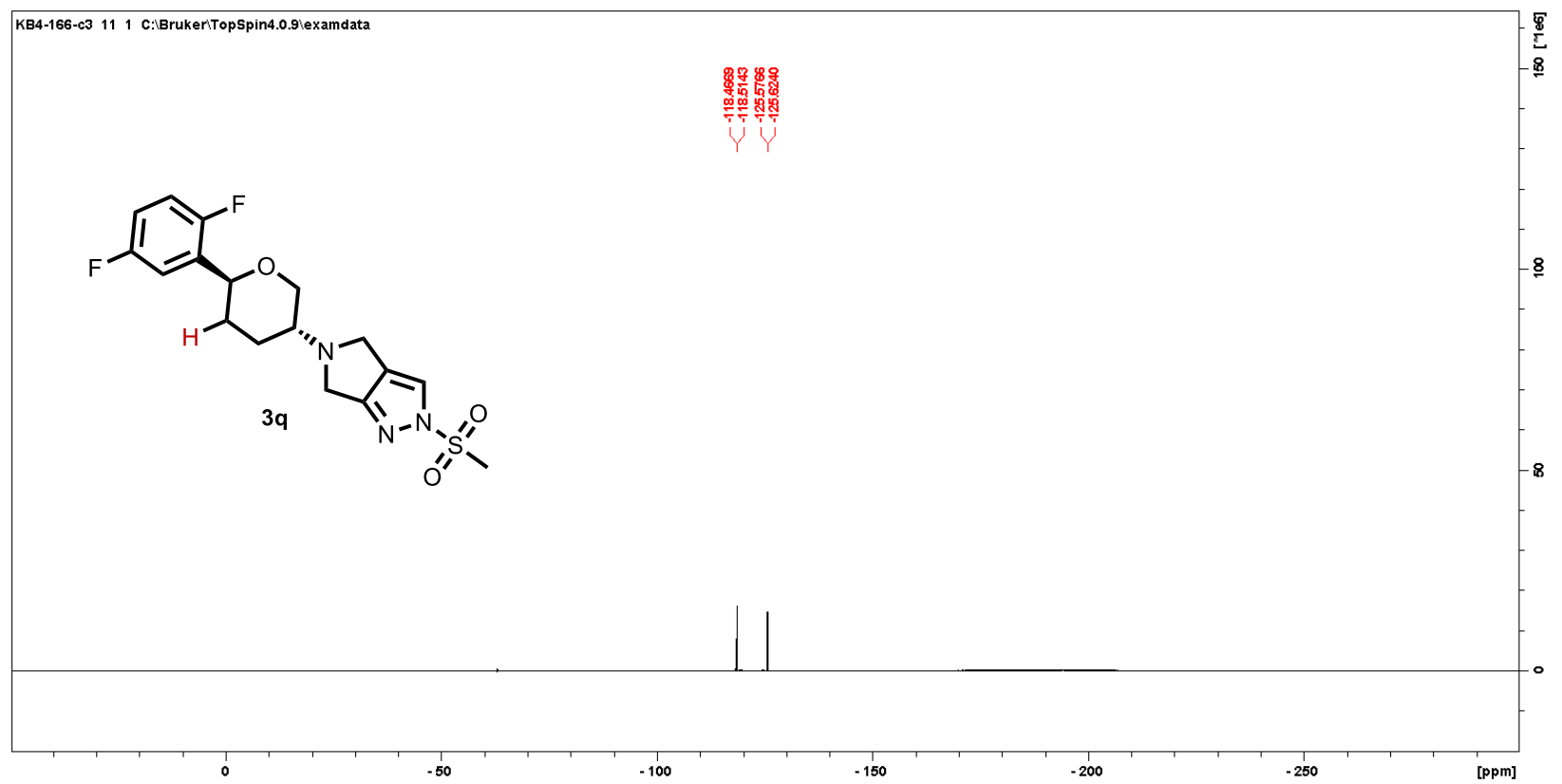


${ }^{13} \mathrm{C}\left\{{ }^{1} \mathrm{H}\right\}$ NMR of 5-((3R,6S)-6-(2,5-difluorophenyl)tetrahydro-2H-pyran-3-yl)-2(methylsulfonyl)-2,4,5,6-tetrahydropyrrolo[3,4-c]pyrazole (3q) in $\mathrm{CDCl}_{3}, 100 \mathrm{MHz}$ :

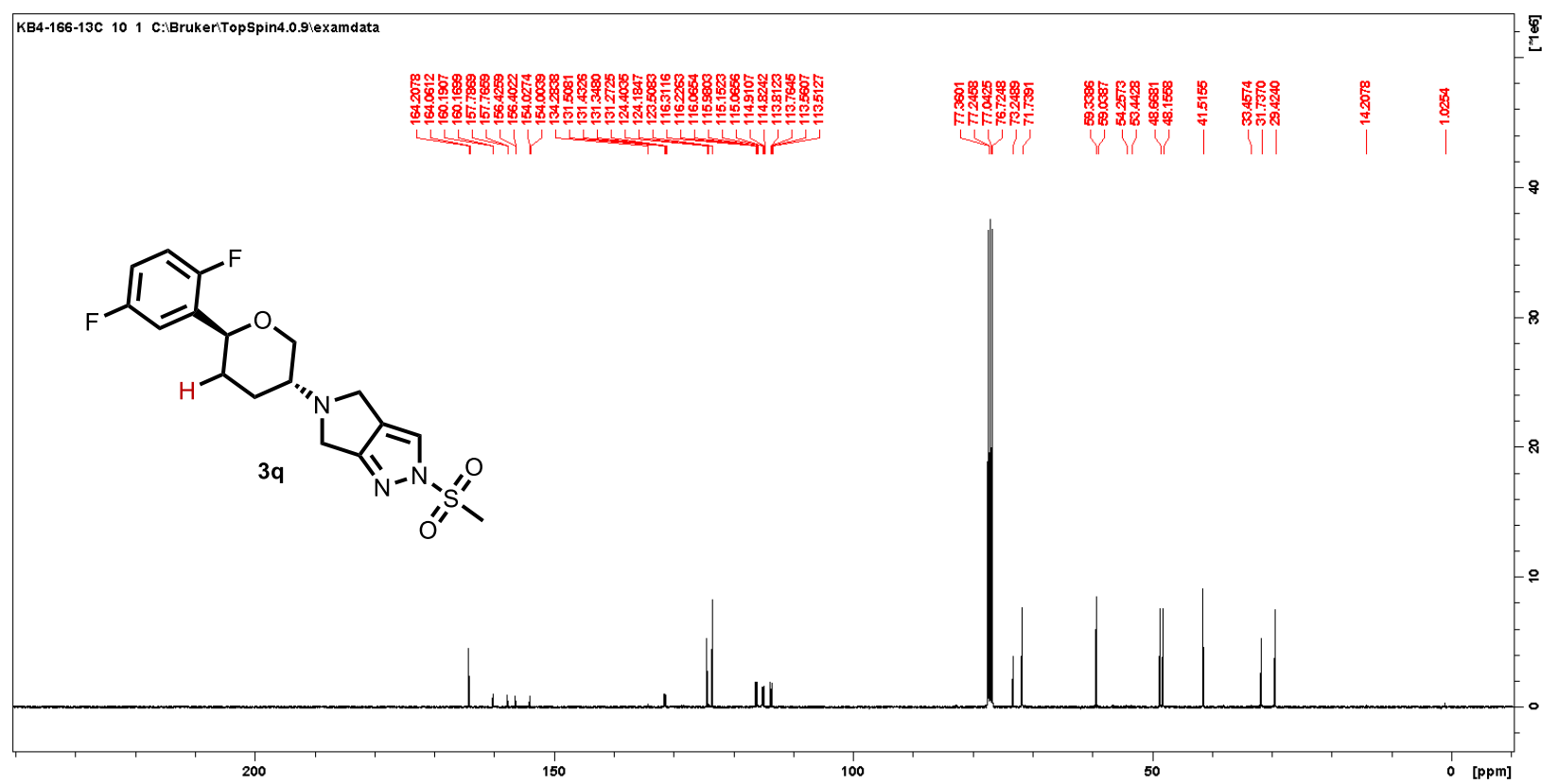

${ }^{1} \mathrm{H}$ NMR of 7-(but-2-yn-1-yl)-3-methyl-1-((4-methylquinazolin-2-yl)methyl)-8-(piperidin-1-yl)3,7-dihydro-1 $\mathrm{H}$-purine-2,6-dione (3r) in $\mathrm{CDCl}_{3}, 400 \mathrm{MHz}$ :

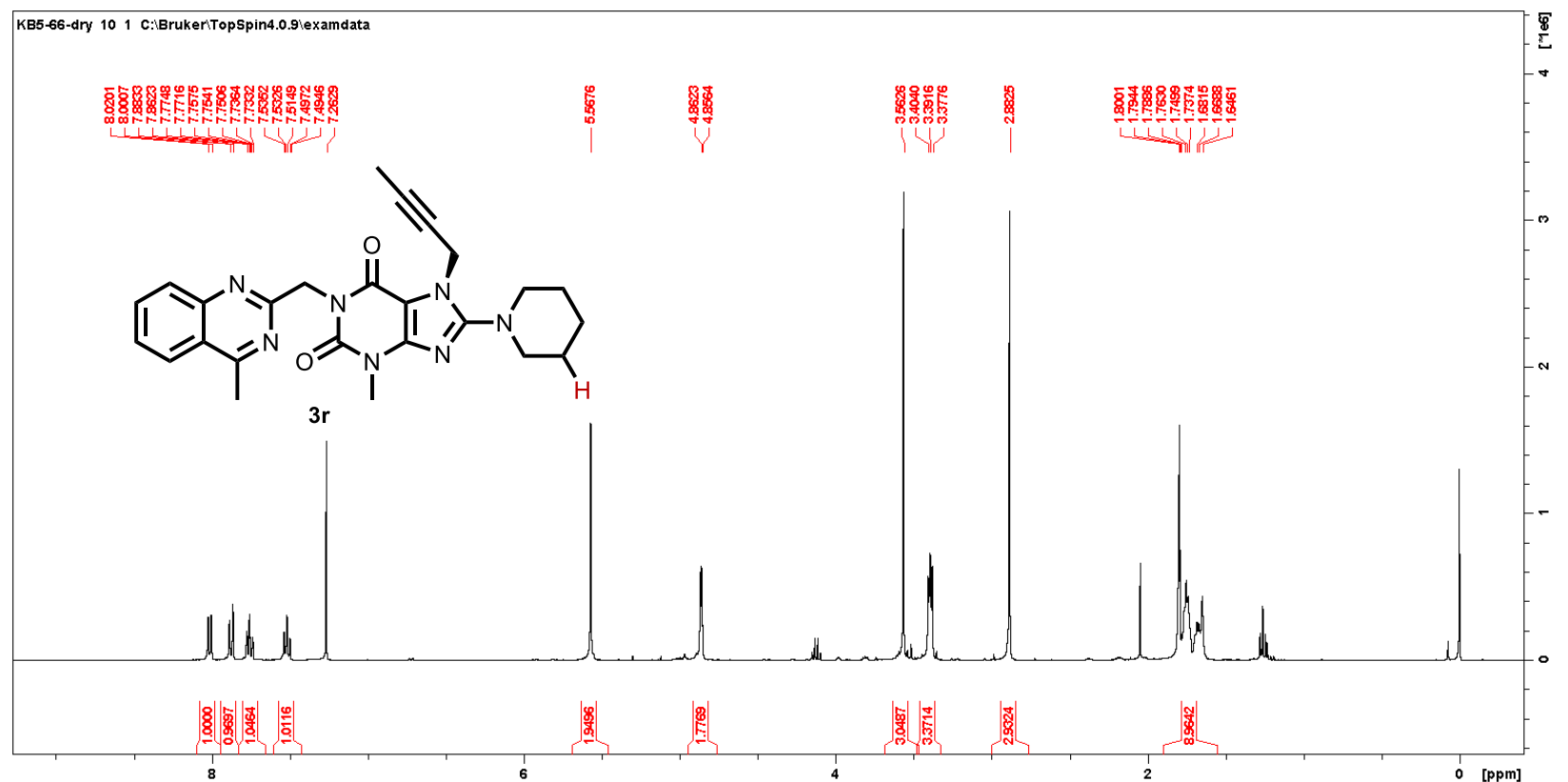


${ }^{13} \mathrm{C}\left\{{ }^{1} \mathrm{H}\right\}$ NMR of 7-(but-2-yn-1-yl)-3-methyl-1-((4-methylquinazolin-2-yl)methyl)-8-(piperidin1-yl)-3,7-dihydro-1 $H$-purine-2,6-dione (3r) in $\mathrm{CDCl}_{3}, 100 \mathrm{MHz}$ :

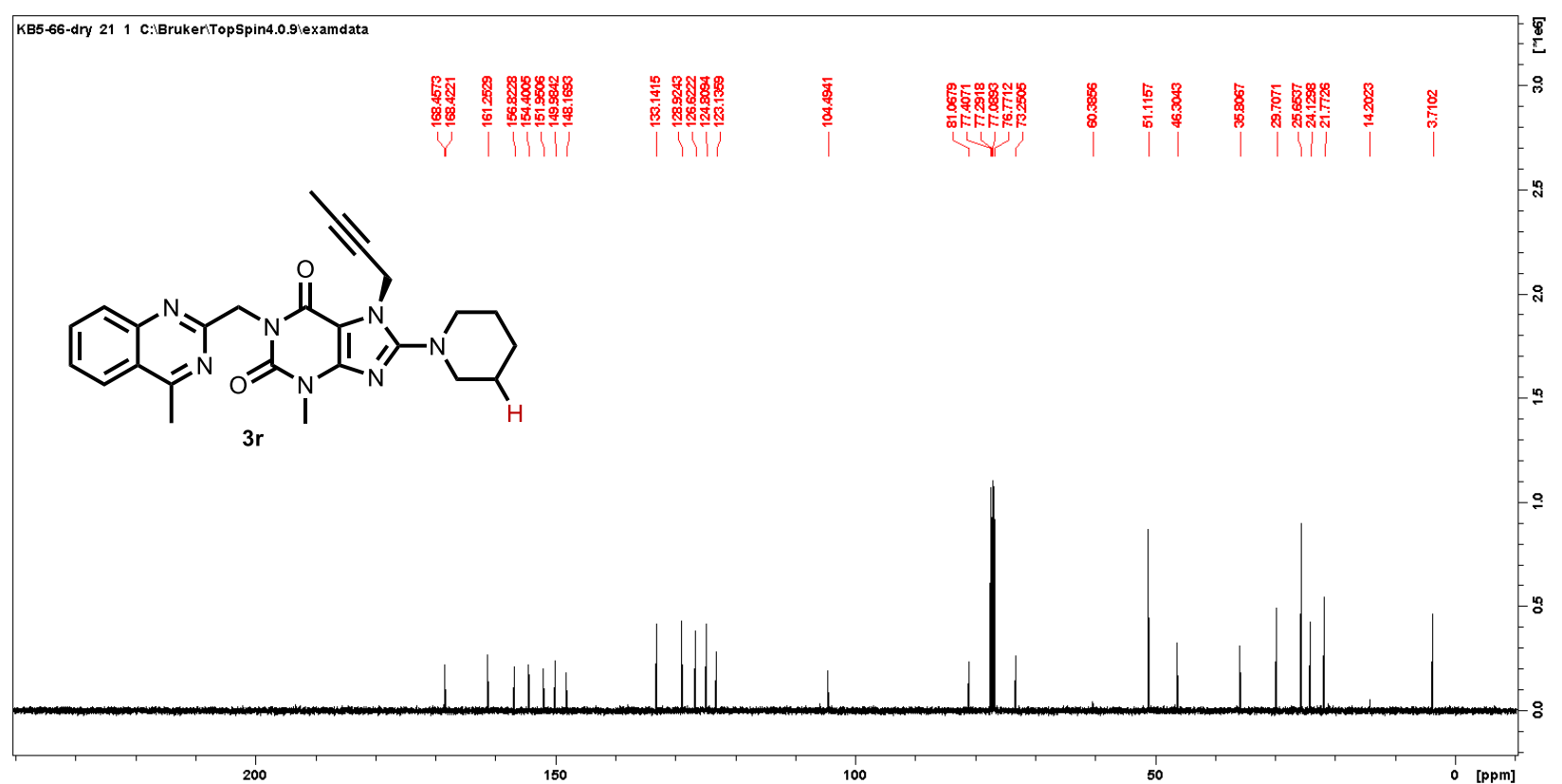

${ }^{1} \mathrm{H}$ NMR of $\beta$-1,3,4,6-Tetra-O-acetyl-2-deoxy-D-glucose (3s) in $\mathrm{CDCl}_{3}, 400 \mathrm{MHz}$ :

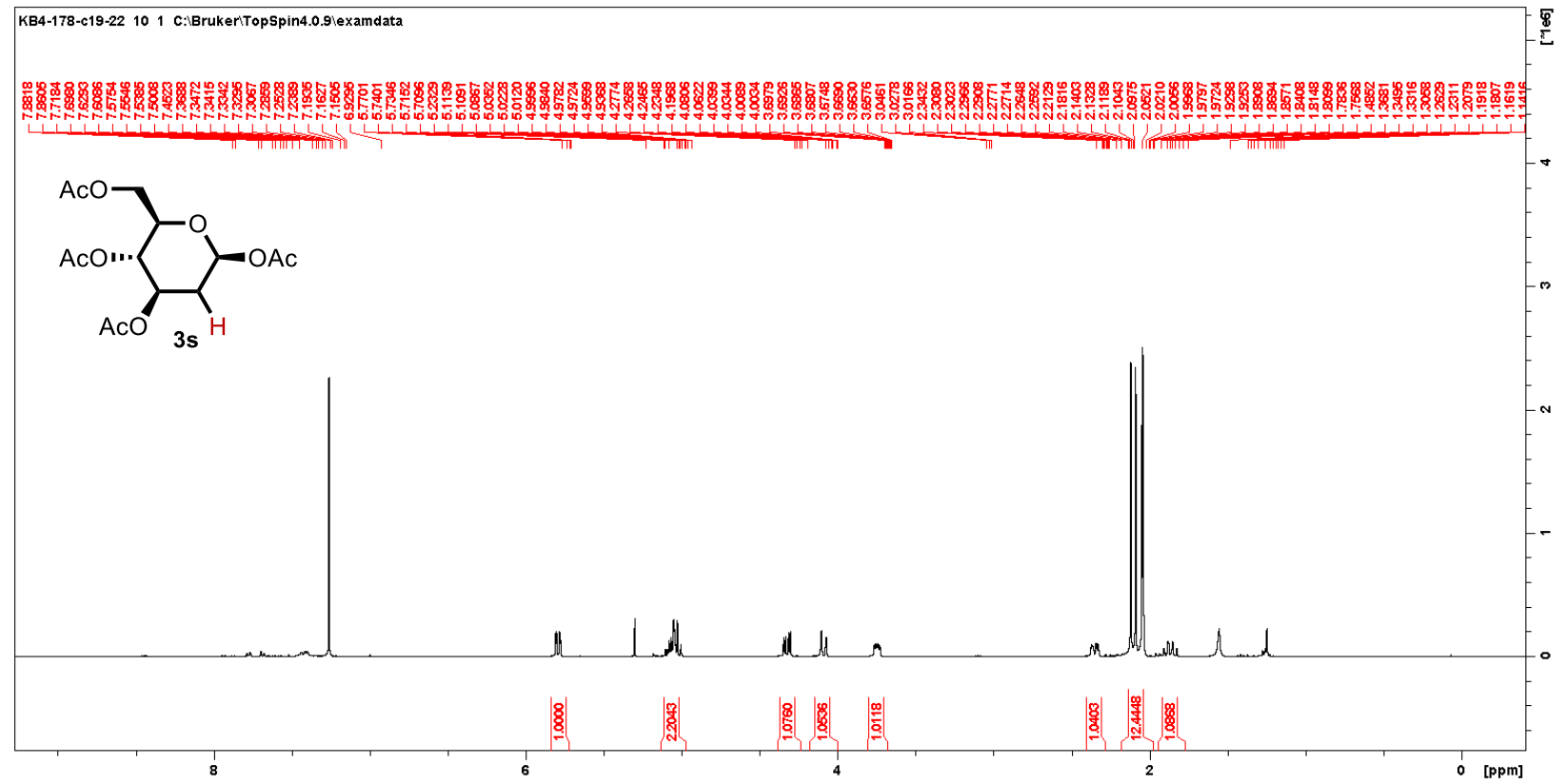


${ }^{13} \mathrm{C}\left\{{ }^{1} \mathrm{H}\right\}$ NMR of $\beta-1,3,4,6$-Tetra-O-acetyl-2-deoxy-D-glucose (3s) in $\mathrm{CDCl}_{3}, 100 \mathrm{MHz}$ :

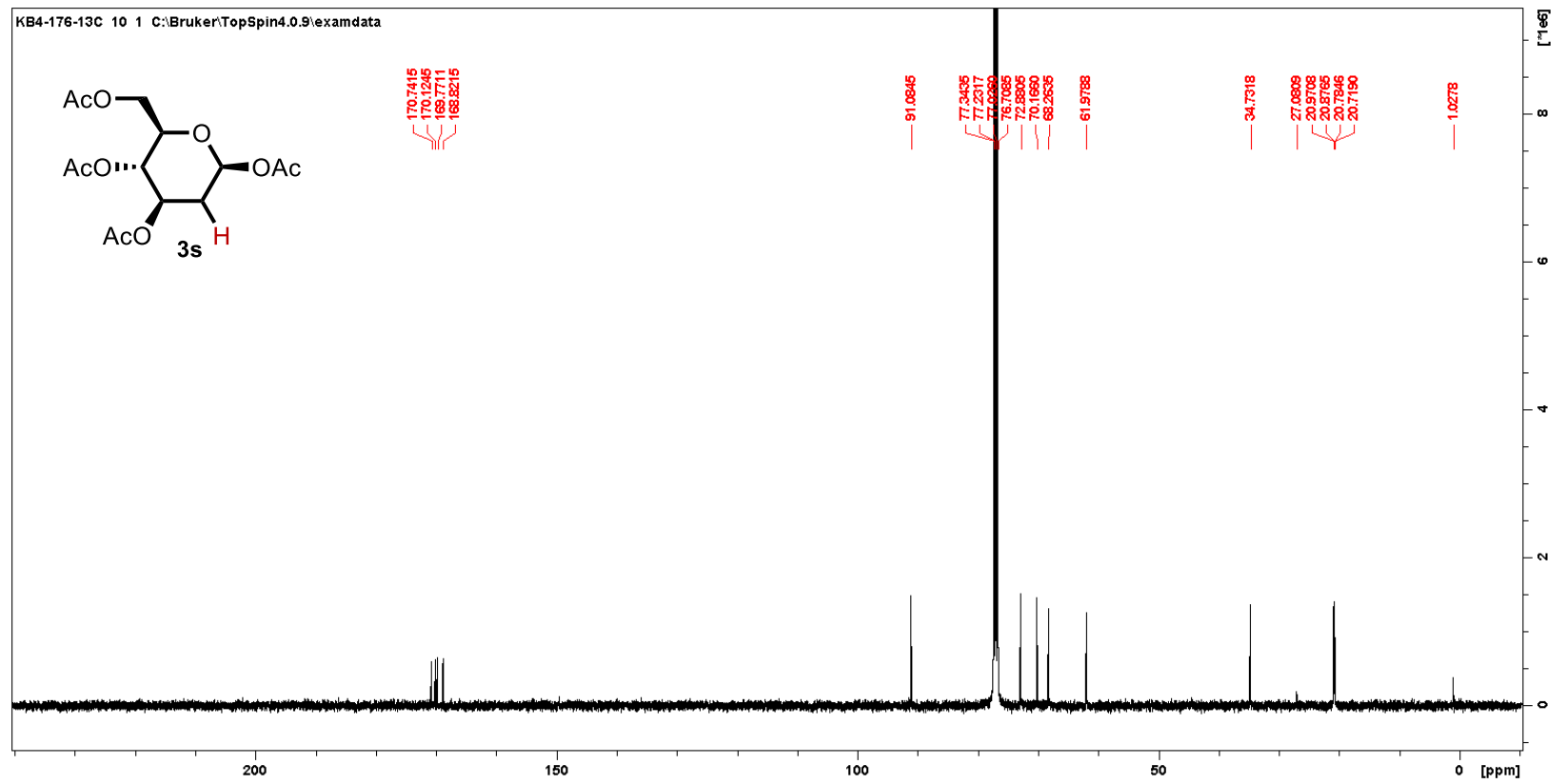

${ }^{1} \mathrm{H}$ NMR of benzyl (3-phenylpropanoyl)- $L$-leucinate (3v) in $\mathrm{CDCl}_{3}, 400 \mathrm{MHz}$ :

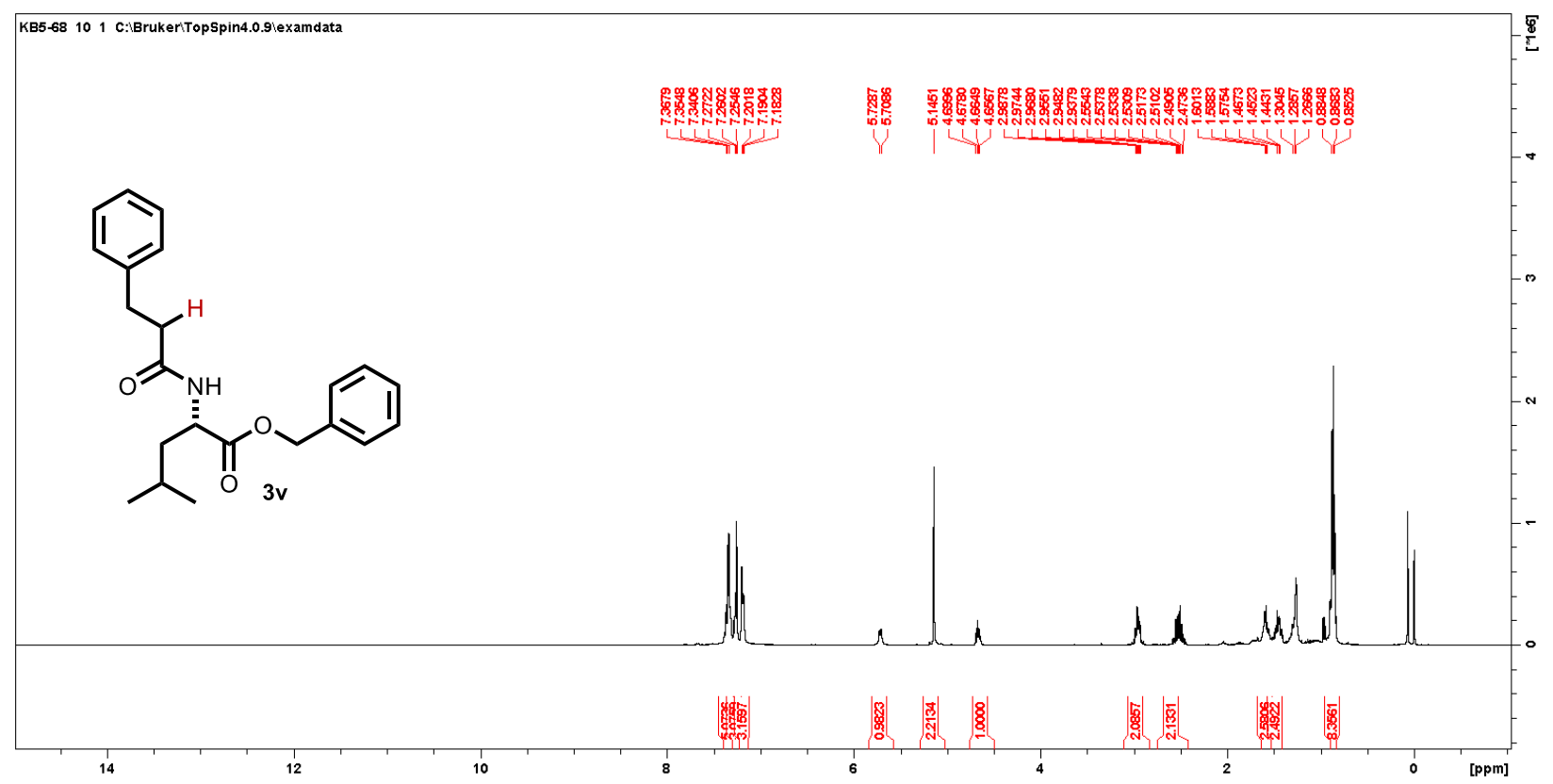


${ }^{13} \mathrm{C}\left\{{ }^{1} \mathrm{H}\right\}$ NMR of benzyl (3-phenylpropanoyl)- $L$-leucinate (3v) in $\mathrm{CDCl}_{3}, 100 \mathrm{MHz}$ :

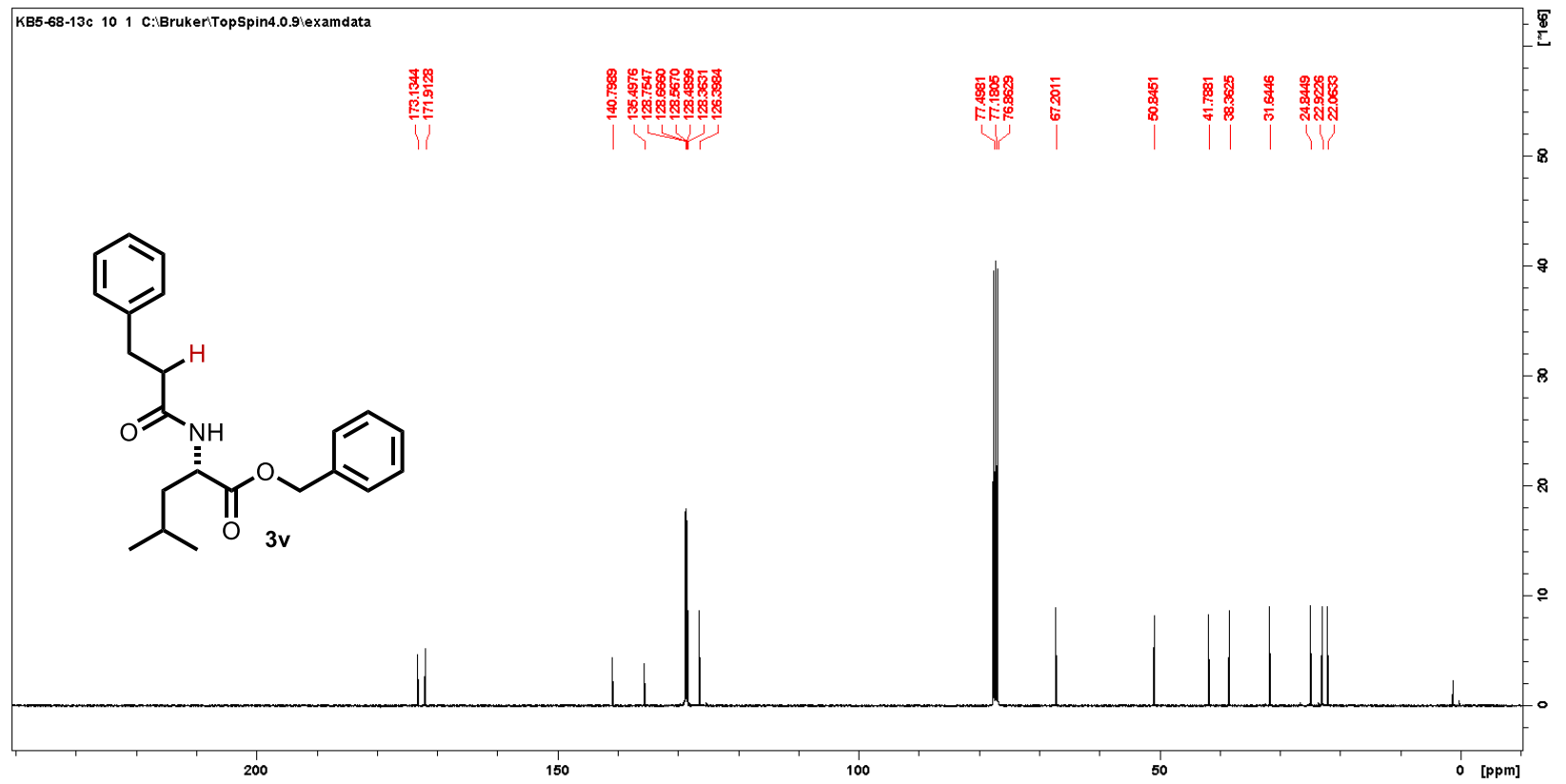

${ }^{1} \mathrm{H}$ NMR of tert-butyl-3-methyl-8-oxo-5-thia-1-azabicyclo[4.2.0]oct-2-ene-2-carboxylate (3y) in $\mathrm{CDCl}_{3}, 400 \mathrm{MHz}$ :

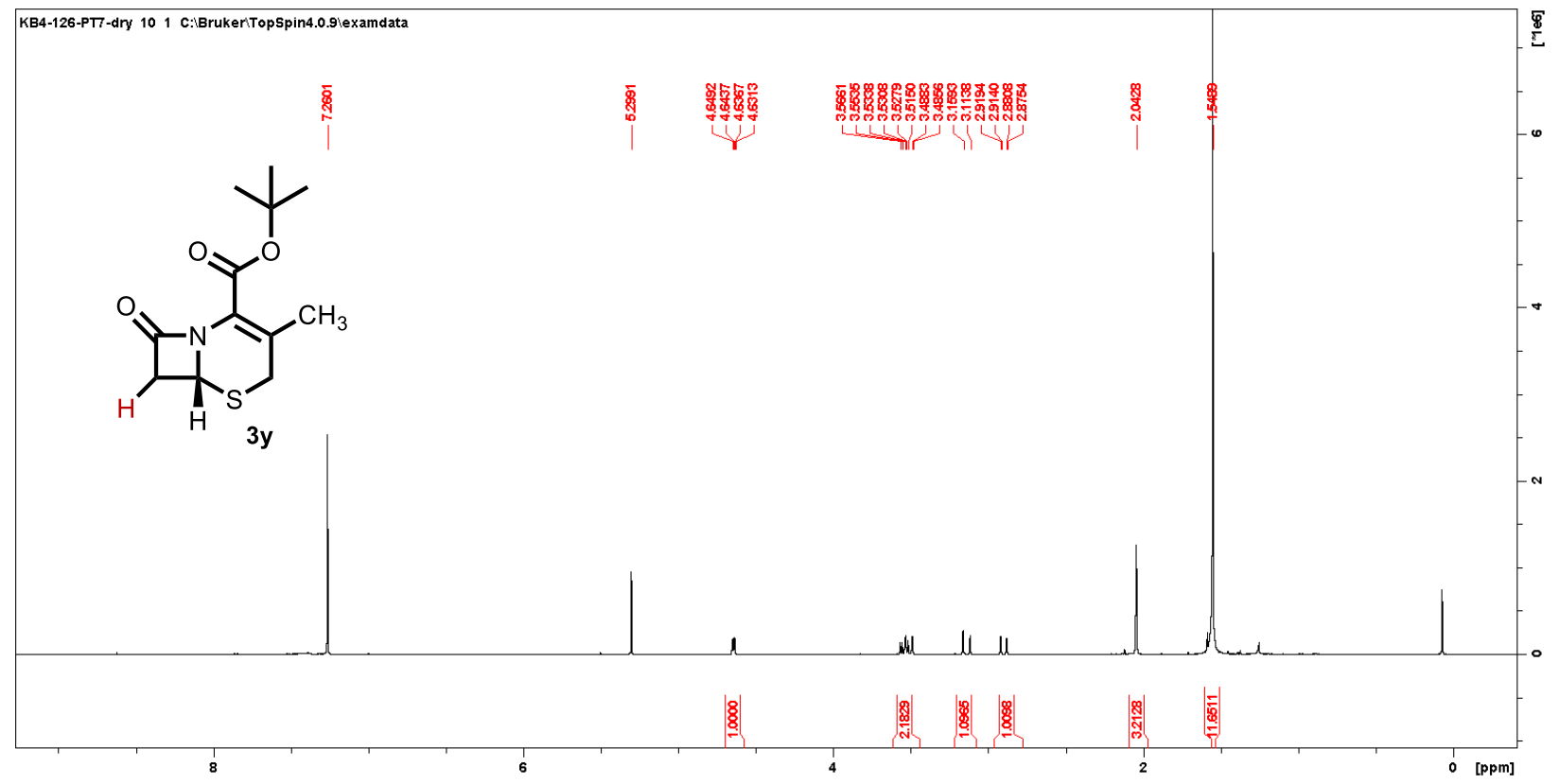


${ }^{13} \mathrm{C}\left\{{ }^{1} \mathrm{H}\right\}$ NMR of tert-butyl-3-methyl-8-oxo-5-thia-1-azabicyclo[4.2.0]oct-2-ene-2-carboxylate (3y) in $\mathrm{CDCl}_{3}, 100 \mathrm{MHz}$ :

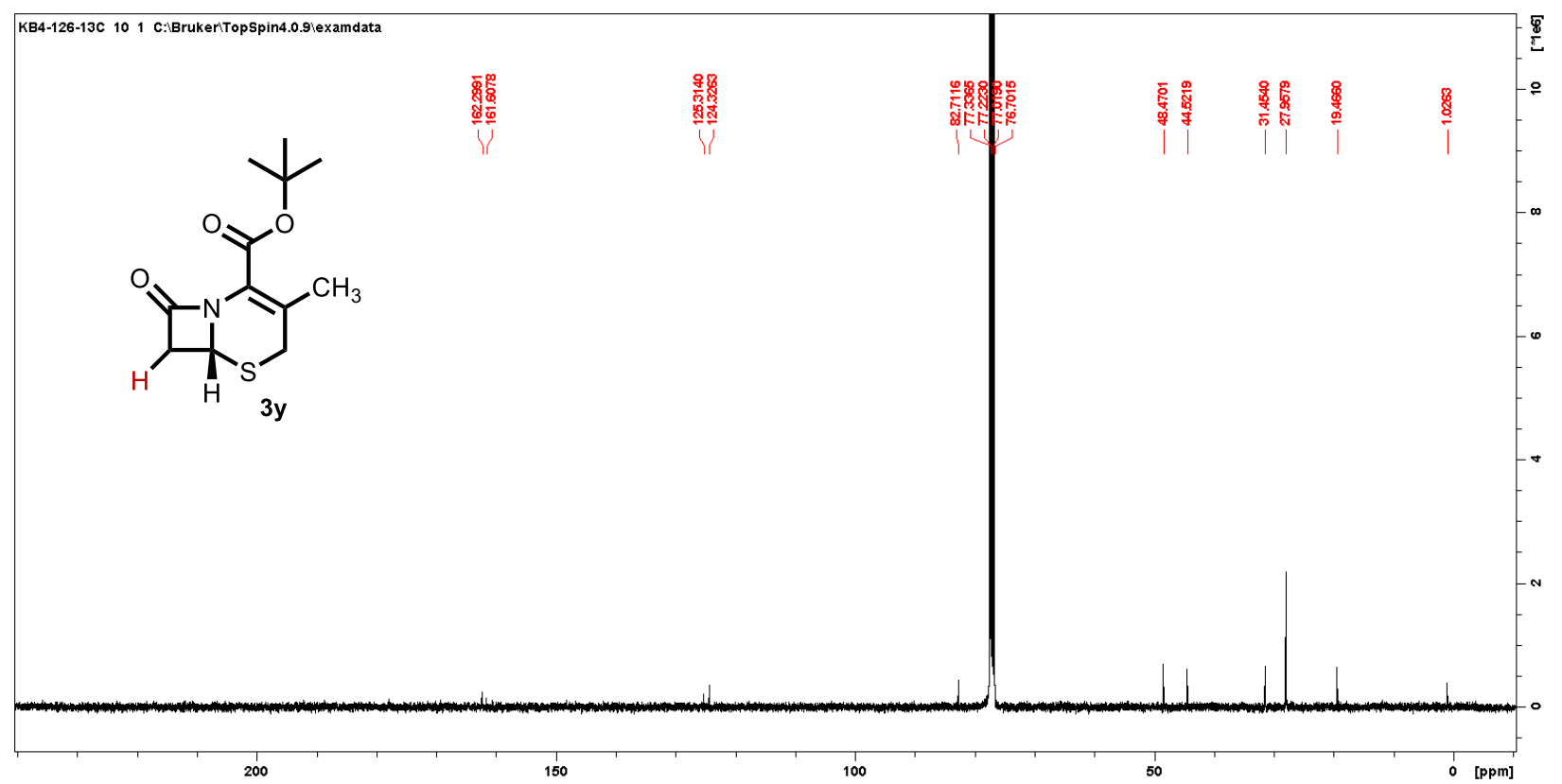

${ }^{1} \mathrm{H}$ NMR of 4-(1-methylcycloheptyl)morpholine (3aa) in $\mathrm{CDCl}_{3}, 400 \mathrm{MHz}$ :

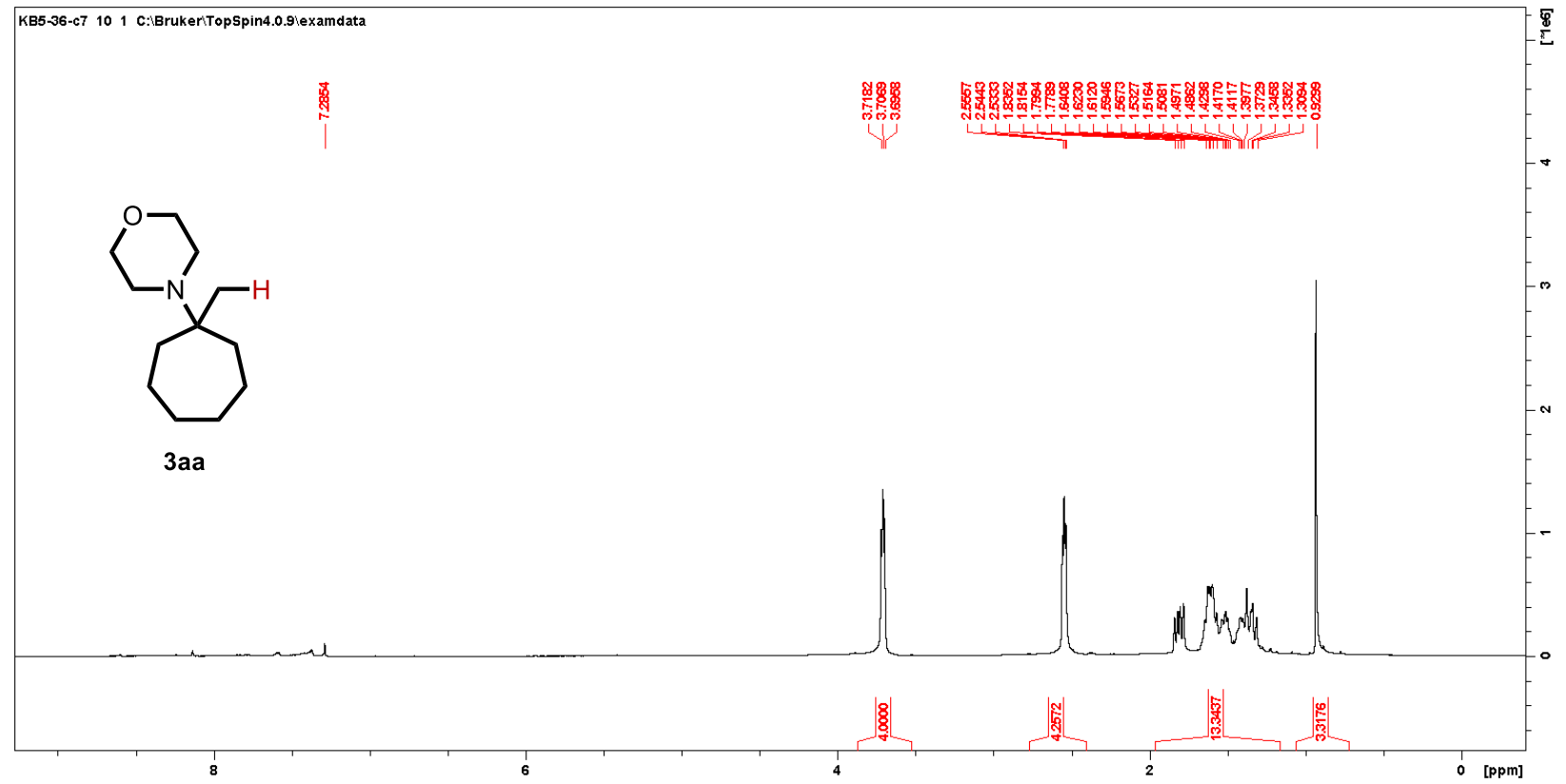


${ }^{13} \mathrm{C}\left\{{ }^{1} \mathrm{H}\right\}$ NMR of 4-(1-methylcycloheptyl)morpholine (3aa) in $\mathrm{CDCl}_{3}, 100 \mathrm{MHz}$ :

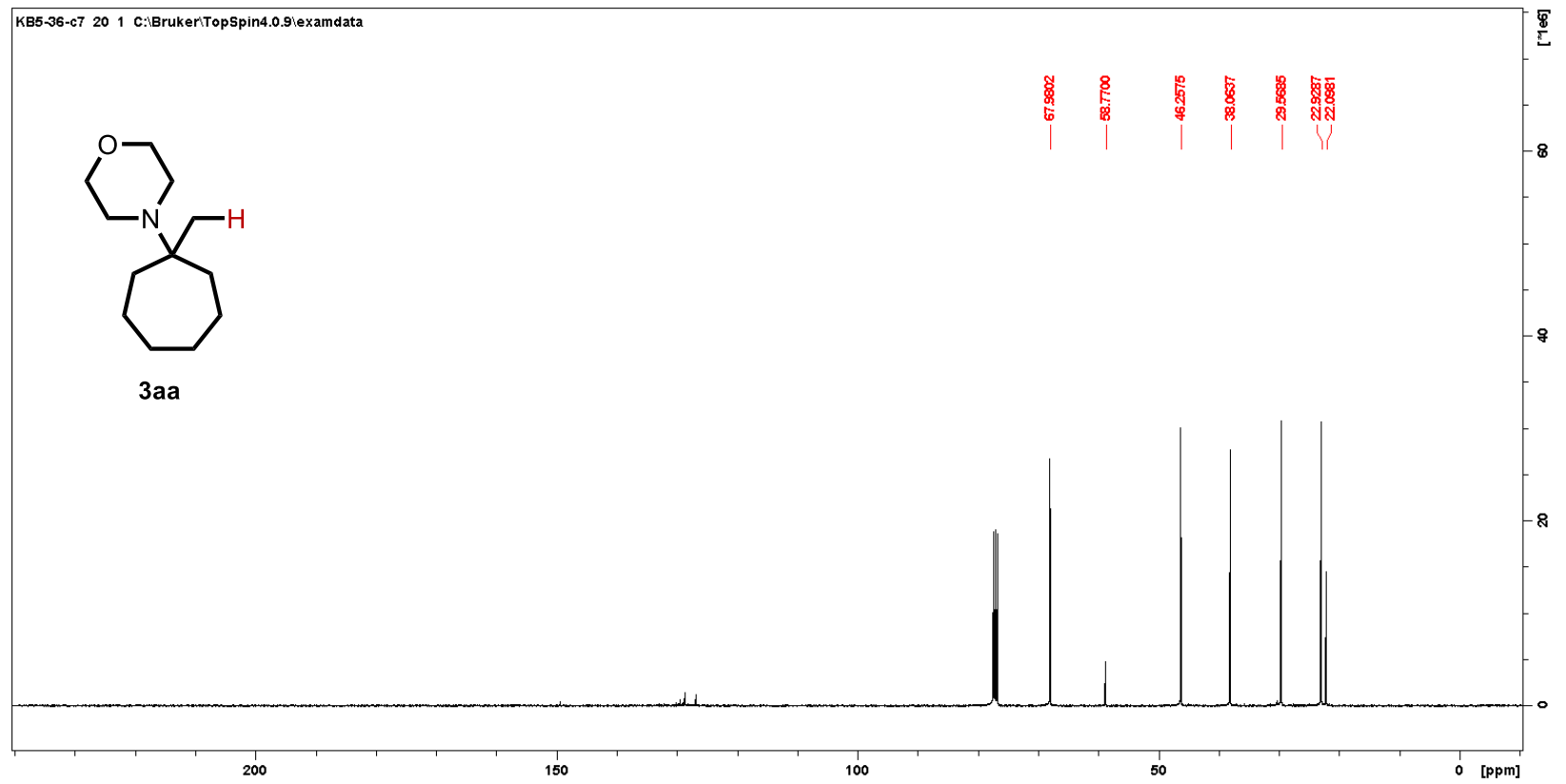

${ }^{1} \mathrm{H}$ NMR of 1-(3-(1H-imidazol-1-yl)propoxy)-2,2,6,6-tetramethylpiperidine (8c) in $\mathrm{CDCl}_{3}, 400$ MHz:

${ }^{1} \mathrm{H} \mathrm{NMR}\left(400 \mathrm{MHz}, \mathrm{CDCl}_{3}\right) \delta 7.47(\mathrm{~s}, 1 \mathrm{H}), 7.02(\mathrm{~s}, 1 \mathrm{H}), 6.90(\mathrm{~s}, 1 \mathrm{H}), 4.07-3.98(\mathrm{~m}, 2 \mathrm{H}), 3.72(\mathrm{t}, J=6.0 \mathrm{~Hz}, 2 \mathrm{H}), 2.02-1.94(\mathrm{~m}, 2 \mathrm{H}), 1.57-1.44(\mathrm{~m}, 1 \mathrm{H}), 1.39(\mathrm{~m}, 4 \mathrm{H})$, $1.32-1.24(\mathrm{~m}, 1 \mathrm{H}), 1.07(\mathrm{~s}, 6 \mathrm{H}), 1.06(\mathrm{~s}, 6 \mathrm{H})$.

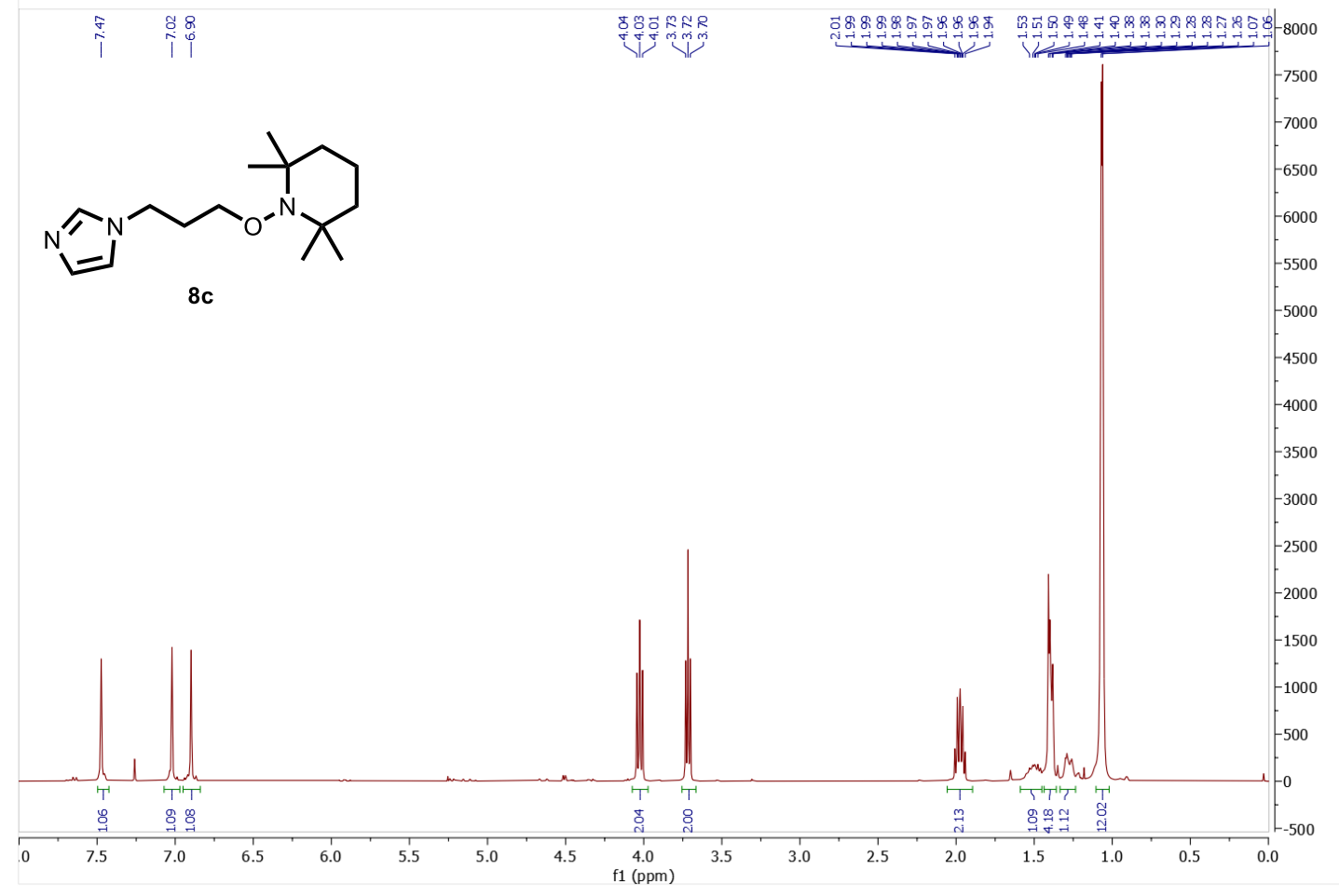


${ }^{13} \mathrm{C}\left\{{ }^{1} \mathrm{H}\right\}$ NMR of 1-(3-(1H-imidazol-1-yl)propoxy)-2,2,6,6-tetramethylpiperidine (8c) in $\mathrm{CDCl}_{3}$, $100 \mathrm{MHz}$ :

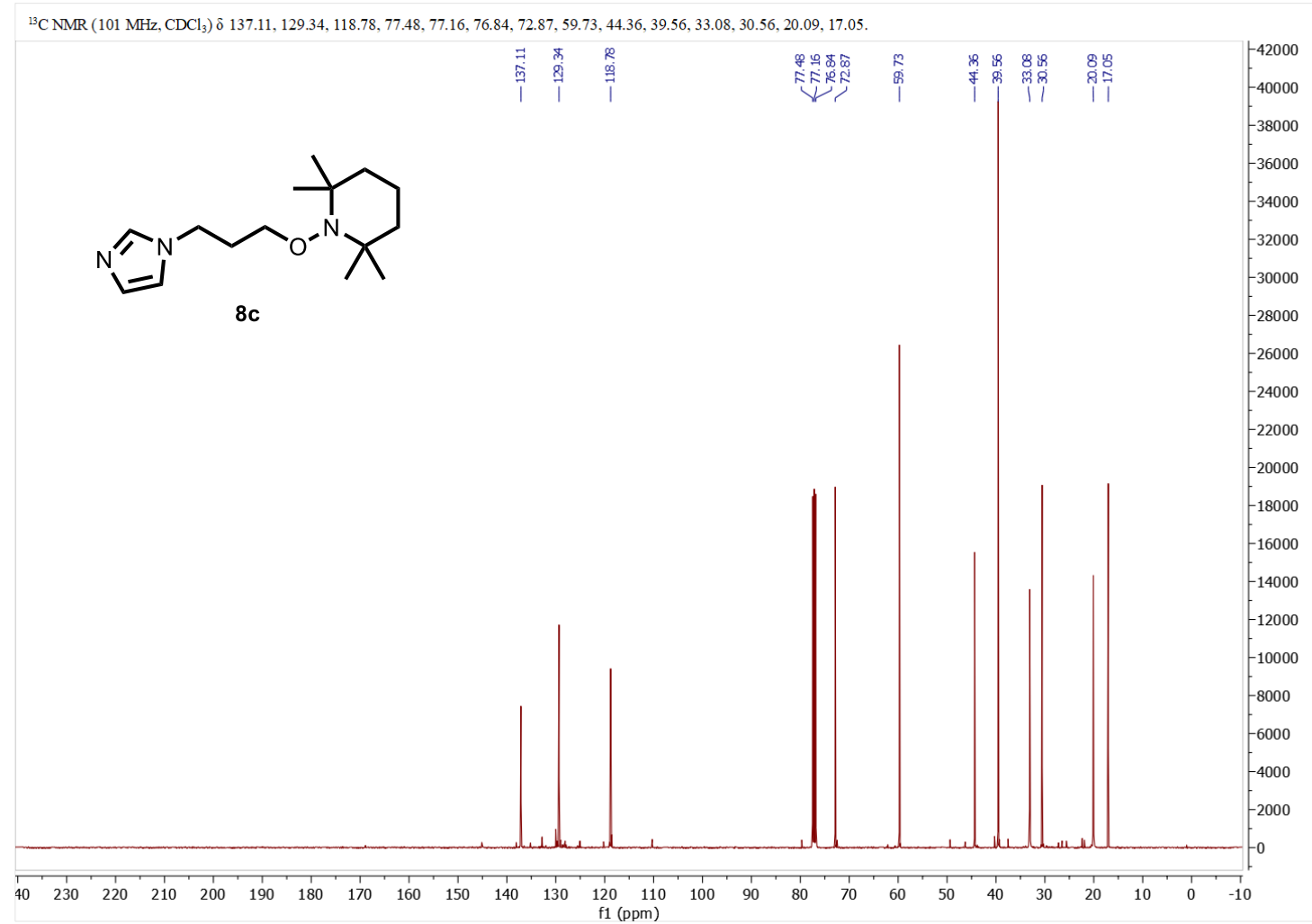




\section{Coordinates and Energies:}

C

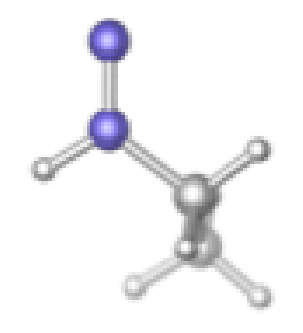
$\mathrm{N}$
$0.41994800 \quad 1.45087100 \quad-0.59958700$
$\mathrm{C}$
$-0.85573100 \quad 1.58974400 \quad-1.37130600$
$\mathrm{H}$
$-0.66175100 \quad 1.16468600 \quad-2.35456700$
$\mathrm{H} \quad-1.60484300 \quad 0.98776900 \quad-0.85045700$
$\mathrm{N}$
$\begin{array}{lll}1.48672000 & 1.07295600 & -1.01965400\end{array}$
$\mathrm{C}$
$\begin{array}{lll}-1.27312300 & 3.04908800 & -1.43496300\end{array}$
$\mathrm{H} \quad-0.53302900 \quad 3.64024400 \quad-1.97807100$
$\mathrm{H} \quad-2.23241500 \quad 3.14118400 \quad-1.94666700$
$\mathrm{H} \quad-1.38659200 \quad 3.47004700 \quad-0.43267700$
$\begin{array}{llll}\mathrm{H} & 0.29044700 & 1.75049900 & 0.39361400\end{array}$

B3LYP-D3/def2-TZVP-SMD(THF)

$H F=-189.3332261$

Zero-point correction $=\quad 0.084573($ Hartree/Particle $)$

Thermal correction to Energy= $\quad 0.089559$

Thermal correction to Enthalpy= $\quad 0.090504$

Thermal correction to Gibbs Free Energy $=\quad 0.057105$

Sum of electronic and zero-point Energies $=\quad-189.248653$ 
Sum of electronic and thermal Energies=

Sum of electronic and thermal Enthalpies=

Sum of electronic and thermal Free Energies=
$-189.243667$

$-189.242722$

$-189.276121$

\section{TS-C-C Itrans $^{- \text {}}$}

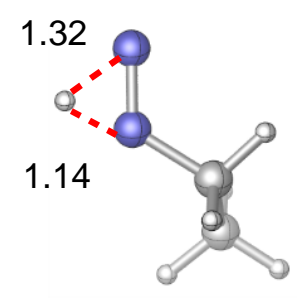

Imaginary Frequency $\left(\mathrm{cm}^{-1}\right)=-2227.41$

$\begin{array}{llll}\mathrm{N} & 0.42374700 & 1.45676700 & -0.56441000 \\ \mathrm{C} & -0.84922200 & 1.58223300 & -1.31790700 \\ \mathrm{H} & -0.64809700 & 1.13943900 & -2.30003400 \\ \mathrm{H} & -1.59246700 & 0.98360300 & -0.78634600 \\ \mathrm{~N} & 1.48342100 & 0.99345800 & -1.08218200 \\ \mathrm{C} & -1.27623000 & 3.03795100 & -1.40376300 \\ \mathrm{H} & -0.53037400 & 3.62943200 & -1.93846700 \\ \mathrm{H} & -2.22487800 & 3.11559000 & -1.93738300 \\ \mathrm{H} & -1.40947800 & 3.46471300 & -0.40764600 \\ \mathrm{H} & 1.31593400 & 1.45966500 & 0.14579900\end{array}$

B3LYP-D3/def2-TZVP-SMD(THF)

$H F=-189.2477615$

Zero-point correction=

0.078672 (Hartree/Particle)

Thermal correction to Energy=

0.083847 
Thermal correction to Enthalpy= $\quad 0.084791$

Thermal correction to Gibbs Free Energy $=\quad 0.051280$

Sum of electronic and zero-point Energies $=\quad-189.169089$

Sum of electronic and thermal Energies $=\quad-189.163914$

Sum of electronic and thermal Enthalpies $=\quad-189.162970$

Sum of electronic and thermal Free Energies $=\quad-189.196482$

$\mathbf{C}^{\mathrm{I}-\text { trans }}$

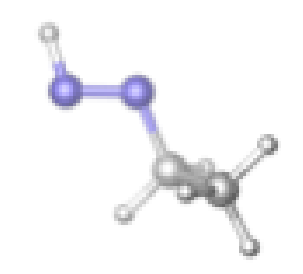

$\begin{array}{lllll}\mathrm{N} & 0.46139000 & 1.75516600 & -0.48507300\end{array}$

$\begin{array}{llll}\text { C } & -0.76884400 & 1.67986400 & -1.27611700\end{array}$

$\mathrm{H} \quad-0.58496900 \quad 1.16370200 \quad-2.22369700$

H $\quad-1.47520000 \quad 1.09616000 \quad-0.67845200$

$\mathrm{N} \quad 1.45705500 \quad 1.30488300 \quad-1.05897800$

C $\quad-1.31690800 \quad 3.08557900 \quad-1.49555200$

$\mathrm{H} \quad-0.62361300 \quad 3.68100200 \quad-2.09335600$

$\mathrm{H} \quad-2.26945700 \quad 3.03299900 \quad-2.02530100$

$\mathrm{H} \quad-1.47919200 \quad 3.59624100 \quad-0.54436300$

$\mathrm{H} \quad 2.25982300 \quad 1.41630100 \quad-0.42141900$

B3LYP-D3/def2-TZVP-SMD(THF)

$\mathrm{HF}=-189.3605108$

Zero-point correction $=\quad 0.085262($ Hartree/Particle $)$ 
$\begin{array}{ll}\begin{array}{l}\text { Thermal correction to Energy= } \\ \text { Thermal correction to Enthalpy= }\end{array} & 0.090151 \\ \text { Thermal correction to Gibbs Free Energy= } & 0.058024 \\ \text { Sum of electronic and zero-point Energies= } & -189.275249 \\ \text { Sum of electronic and thermal Energies= } & -189.270360 \\ \text { Sum of electronic and thermal Enthalpies }= & -189.269415 \\ \text { Sum of electronic and thermal Free Energies }= & -189.302487\end{array}$

TS-C $\mathbf{C}^{\mathrm{I}-\text { trans }_{-}} \mathbf{C}^{\mathrm{I}-c i s}$

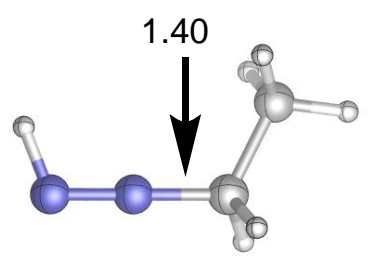

Imaginary Frequency $\left(\mathrm{cm}^{-1}\right)=-709.42$

$\begin{array}{llll}\mathrm{N} & 0.47556000 & 1.33279200 & -1.01078400 \\ \mathrm{C} & -0.84306200 & 1.63336200 & -1.38178700 \\ \mathrm{H} & -1.00484700 & 1.17513500 & -2.36642500 \\ \mathrm{H} & -1.49879600 & 1.07754700 & -0.69848100 \\ \mathrm{~N} & 1.62819000 & 1.07022900 & -0.68798900 \\ \mathrm{C} & -1.24105600 & 3.11665500 & -1.41257000 \\ \mathrm{H} & -0.62235300 & 3.66565400 & -2.12528700 \\ \mathrm{H} & -2.28845700 & 3.21694600 & -1.71318500 \\ \mathrm{H} & -1.11962500 & 3.56730100 & -0.42550600 \\ \mathrm{H} & 2.17453200 & 1.95627700 & -0.48029500\end{array}$

B3LYP-D3/def2-TZVP-SMD(THF) 


$$
\mathrm{HF}=-189.2815614
$$

Zero-point correction $=\quad 0.080669($ Hartree/Particle $)$

Thermal correction to Energy $=\quad 0.085780$

Thermal correction to Enthalpy $=\quad 0.086724$

Thermal correction to Gibbs Free Energy $=\quad 0.053063$

Sum of electronic and zero-point Energies $=\quad-189.200892$

Sum of electronic and thermal Energies $=\quad-189.195782$

Sum of electronic and thermal Enthalpies $=\quad-189.194837$

Sum of electronic and thermal Free Energies $=\quad-189.228498$

$\mathbf{C}^{\mathrm{I}-c i s}$

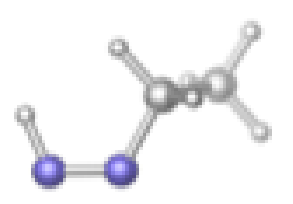
$\mathrm{N}$
$\begin{array}{llll}0.49706600 & 1.82770500 & -0.59818600\end{array}$
C
$-0.75484600 \quad 1.75478100 \quad-1.35907300$
$\mathrm{H}$
$-0.57044400 \quad 1.33305800 \quad-2.35701200$
$\mathrm{H}$
$\begin{array}{lll}-1.40877200 & 1.07708600 & -0.80304900\end{array}$
$\mathrm{N}$
$\begin{array}{lll}1.55105900 & 1.50052000 & -1.14222500\end{array}$
$\mathrm{C}$
$\begin{array}{llll}-1.38924100 & 3.13799400 & -1.44229100\end{array}$
$\mathrm{H}$
$-0.74702500 \quad 3.82598800 \quad-1.99585600$
$\mathrm{H}$
$\begin{array}{lll}-2.34933700 & 3.07369600 & -1.95675200\end{array}$
$\mathrm{H}$
$\begin{array}{llll}-1.55889600 & 3.54894700 & -0.44570300\end{array}$
$\mathrm{H}$
$\begin{array}{lll}1.39790800 & 1.18941300 & -2.12840000\end{array}$ 
B3LYP-D3/def2-TZVP-SMD(THF)

$H F=-189.3569015$

Zero-point correction $=$

0.084786 (Hartree/Particle)

Thermal correction to Energy=

0.089664

Thermal correction to Enthalpy=

0.090608

Thermal correction to Gibbs Free Energy $=\quad 0.057578$

Sum of electronic and zero-point Energies $=\quad-189.272116$

Sum of electronic and thermal Energies $=\quad-189.267238$

Sum of electronic and thermal Enthalpies $=\quad-189.266294$

Sum of electronic and thermal Free Energies $=\quad-189.299323$

\section{2-phenylcyclopropyl-methyl-nitrenyl radical (" $R=M e ")$}

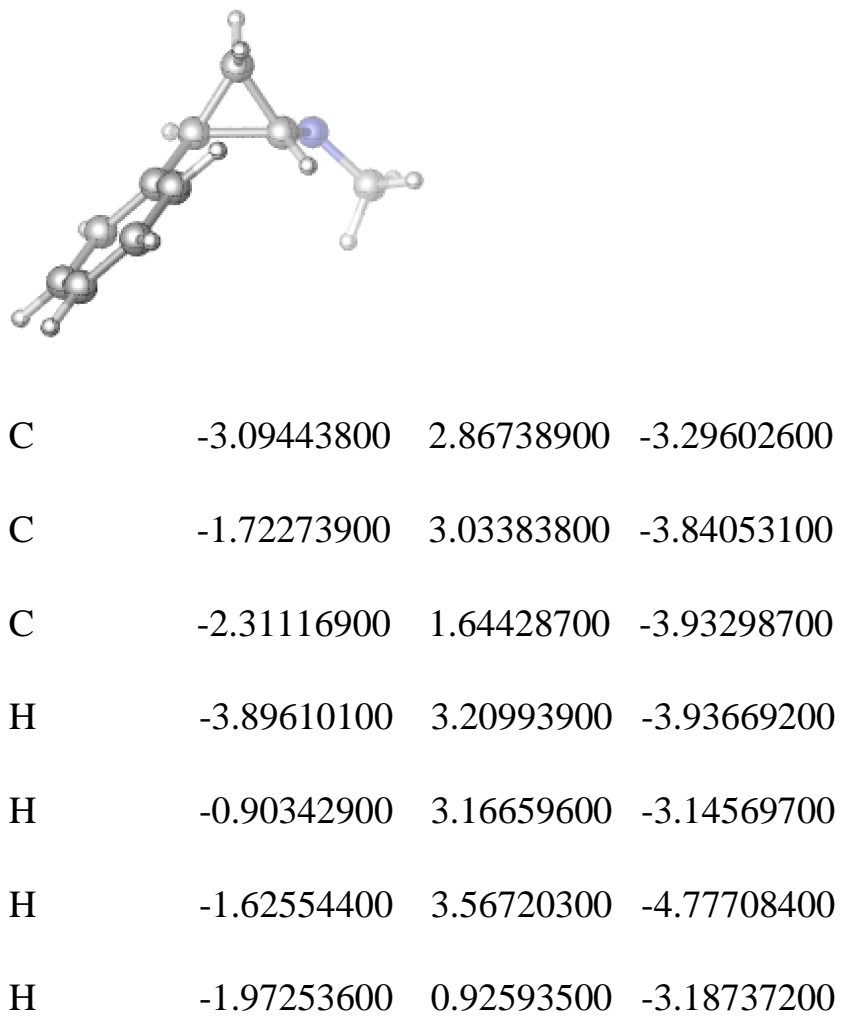




\begin{tabular}{|c|c|c|c|}
\hline $\mathrm{C}$ & -3.42429200 & 2.83215200 & -1.85515900 \\
\hline $\mathrm{C}$ & -4.74702500 & 3.06006900 & -1.45559000 \\
\hline $\mathrm{C}$ & -2.47198800 & 2.56283400 & -0.86392700 \\
\hline $\mathrm{C}$ & -5.10715900 & 3.02268000 & -0.11392000 \\
\hline $\mathrm{H}$ & -5.49849600 & 3.27028800 & -2.20785000 \\
\hline $\mathrm{C}$ & -2.83282600 & 2.52139300 & 0.47716700 \\
\hline $\mathrm{H}$ & -1.44000200 & 2.38232400 & -1.13760300 \\
\hline $\mathrm{C}$ & -4.15134700 & 2.75154500 & 0.86030900 \\
\hline $\mathrm{H}$ & -6.13642800 & 3.20546500 & 0.17041400 \\
\hline $\mathrm{H}$ & -2.07969100 & 2.31152100 & 1.22710000 \\
\hline $\mathrm{H}$ & -4.42953300 & 2.72115100 & 1.90643800 \\
\hline $\mathrm{N}$ & -2.77294500 & 1.19221700 & -5.15204100 \\
\hline $\mathrm{C}$ & -2.93918400 & -0.23699000 & -5.22118100 \\
\hline $\mathrm{H}$ & -3.72195400 & -0.57376100 & -4.52441700 \\
\hline $\mathrm{H}$ & -3.23071200 & -0.53461500 & -6.22915800 \\
\hline $\mathrm{H}$ & -2.02153400 & -0.77623300 & -4.94449600 \\
\hline
\end{tabular}

\section{B3LYP-D3/def2-TZVP-SMD(THF)}

$\mathrm{HF}=-443.1506788$

Zero-point correction $=\quad 0.192910($ Hartree/Particle $)$

Thermal correction to Energy= $\quad 0.203225$

Thermal correction to Enthalpy= $\quad 0.204170$

Thermal correction to Gibbs Free Energy $=\quad 0.155441$

Sum of electronic and zero-point Energies $=\quad-442.957769$

Sum of electronic and thermal Energies $=\quad-442.947453$ 
Sum of electronic and thermal Enthalpies $=\quad-442.946509$

Sum of electronic and thermal Free Energies $=\quad-442.995238$

M06-2X/def2-TZVP-SMD(MeCN)

$\mathrm{HF}=-442.9319762$

M06-2X/def2-TZVP

$H F=-442.9149203$

Solvent correction $=-0.0170559$

DLPNO-CCSD(T)/def2-TZVPP

$\mathrm{HF}=-442.135809413248$

TS-ring opening of 2-phenylcyclopropyl-methyl-nitrenyl radical (" $R=M e ")$

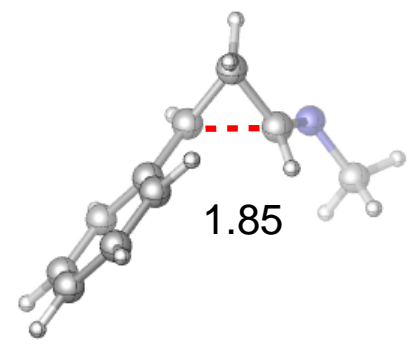

Imaginary Frequency $\left(\mathrm{cm}^{-1}\right)=-402.61$

C $\quad-3.06820600 \quad 2.95073100 \quad-3.28746200$

$\begin{array}{llll}\text { C } & -1.70489000 & 3.03466700 & -3.85366100\end{array}$

C $\quad-2.20044200 \quad 1.62635400 \quad-3.97677200$

$\mathrm{H} \quad-3.87654300 \quad 3.22534200 \quad-3.95061300$

$\mathrm{H} \quad-0.88133100 \quad 3.19410400 \quad-3.16764300$

$\begin{array}{llll}\mathrm{H} & -1.61086500 & 3.56871700 & -4.79192700\end{array}$

$\mathrm{H} \quad-1.93192800 \quad 0.94195000 \quad-3.17162400$

$\begin{array}{llll}\text { C } & -3.40061800 & 2.86109700 & -1.86934100\end{array}$ 


\begin{tabular}{|c|c|c|c|}
\hline $\mathrm{C}$ & -4.74532600 & 2.97493000 & -1.47694600 \\
\hline $\mathrm{C}$ & -2.43792000 & 2.65158600 & -0.86770500 \\
\hline $\mathrm{C}$ & -5.11201800 & 2.88971600 & -0.14167600 \\
\hline $\mathrm{H}$ & -5.50367700 & 3.13535600 & -2.23451400 \\
\hline $\mathrm{C}$ & -2.80880000 & 2.56160900 & 0.46695500 \\
\hline $\mathrm{H}$ & -1.39241900 & 2.55538900 & -1.13098200 \\
\hline $\mathrm{C}$ & -4.14562400 & 2.68074500 & 0.83954200 \\
\hline $\mathrm{H}$ & -6.15491700 & 2.98572800 & 0.13534900 \\
\hline $\mathrm{H}$ & -2.04922600 & 2.40031500 & 1.22242100 \\
\hline $\mathrm{H}$ & -4.43036600 & 2.61247400 & 1.88202300 \\
\hline $\mathrm{N}$ & -2.68479500 & 1.16365500 & -5.14048900 \\
\hline $\mathrm{C}$ & -3.07055000 & -0.22646900 & -5.14947800 \\
\hline $\mathrm{H}$ & -4.15054200 & -0.31212400 & -4.96026500 \\
\hline $\mathrm{H}$ & -2.89303100 & -0.65271700 & -6.14017100 \\
\hline $\mathrm{H}$ & -2.55303700 & -0.83992800 & -4.39932400 \\
\hline
\end{tabular}

B3LYP-D3/def2-TZVP-SMD(THF)

$H F=-443.1497782$

Zero-point correction $=\quad 0.191923($ Hartree/Particle $)$

Thermal correction to Energy= $\quad 0.201951$

Thermal correction to Enthalpy= $\quad 0.202895$

Thermal correction to Gibbs Free Energy $=\quad 0.154953$

Sum of electronic and zero-point Energies $=\quad-442.957855$

Sum of electronic and thermal Energies $=\quad-442.947827$

Sum of electronic and thermal Enthalpies $=\quad-442.946883$ 
Sum of electronic and thermal Free Energies= $-442.994825$

M06-2X/def2-TZVP-SMD(MeCN)

$H F=-442.9279961$

M06-2X/def2-TZVP

$H F=-442.9105839$

Solvent correction $=-0.0174122$

DLPNO-CCSD(T)/def2-TZVPP

$H F=-442.133056199217$

Ring-opened product of 2-phenylcyclopropyl-methyl-nitrenyl radical (" $R=M e$ ")

$\begin{array}{llll} & & & \\ \mathrm{C} & -3.46347700 & 3.10527600 & -3.06106800 \\ \mathrm{C} & -2.23995500 & 2.70690900 & -3.82458700 \\ \mathrm{H} & -2.32987000 & 1.25908100 & -4.24018300 \\ \mathrm{H} & -1.33713100 & 2.84013600 & -3.22143000 \\ \mathrm{H} & -2.13876700 & 3.31787400 & -4.72346200 \\ \mathrm{H} & -2.37134700 & 0.53147100 & -3.41765600 \\ \mathrm{C} & -3.62431600 & 3.04484600 & -1.66234100 \\ \mathrm{C} & -4.86376500 & 3.42982000 & -1.07638000 \\ \mathrm{C} & -2.59903800 & 2.61115300 & -0.77659400 \\ \mathrm{C} & -5.05783800 & 3.38665800 & 0.28950000\end{array}$




\begin{tabular}{|c|c|c|c|c|}
\hline $\mathrm{H}$ & -5.66432900 & 3.76387000 & \multicolumn{2}{|c|}{-1.72629100} \\
\hline $\mathrm{C}$ & -2.80722500 & 2.57108100 & \multicolumn{2}{|c|}{0.58987400} \\
\hline $\mathrm{H}$ & -1.64098700 & 2.30261700 & \multicolumn{2}{|c|}{-1.17375500} \\
\hline $\mathrm{C}$ & -4.03260300 & 2.95699500 & \multicolumn{2}{|c|}{1.13782300} \\
\hline $\mathrm{H}$ & -6.01188500 & 3.68740900 & \multicolumn{2}{|c|}{0.70576200} \\
\hline $\mathrm{H}$ & -2.00934600 & 2.23480100 & \multicolumn{2}{|c|}{1.24135100} \\
\hline $\mathrm{H}$ & -4.18753700 & 2.92296700 & \multicolumn{2}{|c|}{2.20873400} \\
\hline $\mathrm{N}$ & -2.38538200 & 0.90080200 & \multicolumn{2}{|c|}{-5.44999800} \\
\hline $\mathrm{C}$ & -2.49400500 & -0.51546800 & \multicolumn{2}{|c|}{-5.74875900} \\
\hline $\mathrm{H}$ & -3.40331100 & -0.68987400 & \multicolumn{2}{|c|}{-6.33016300} \\
\hline $\mathrm{H}$ & -1.65153200 & -0.81520800 & \multicolumn{2}{|c|}{-6.37753300} \\
\hline $\mathrm{H}$ & -2.51580600 & -1.15427000 & \multicolumn{2}{|c|}{-4.85575400} \\
\hline \multicolumn{5}{|c|}{ B3LYP-D3/def2-TZVP-SMD(THF) } \\
\hline \multicolumn{5}{|c|}{$H F=-443.1765013$} \\
\hline & correction $=$ & & \multicolumn{2}{|c|}{0.192559 (Hartree/Particle) } \\
\hline & orrection to Ene & $\mathrm{rgy}=$ & \multicolumn{2}{|c|}{0.203229} \\
\hline & rrection to Entl & halpy $=$ & \multicolumn{2}{|c|}{0.204173} \\
\hline \multicolumn{4}{|c|}{ Thermal correction to Gibbs Free Energy= } & 0.154069 \\
\hline \multicolumn{4}{|c|}{ Sum of electronic and zero-point Energies= } & -442.983942 \\
\hline \multicolumn{4}{|c|}{ Sum of electronic and thermal Energies= } & -442.973272 \\
\hline \multicolumn{4}{|c|}{ Sum of electronic and thermal Enthalpies= } & -442.972328 \\
\hline \multicolumn{4}{|c|}{ Sum of electronic and thermal Free Energies= } & -443.022433 \\
\hline \multicolumn{5}{|c|}{ M06-2X/def2-TZVP-SMD(MeCN) } \\
\hline
\end{tabular}


M06-2X/def2-TZVP

$H F=-442.9341556$

Solvent correction $=-0.016182$

DLPNO-CCSD(T)/def2-TZVPP

$H F=-442.161568037602$

2-phenylcyclopropyl-amidyl-nitrenyl radical (" $R=\mathrm{N}(\mathrm{OBn}) B z$ ")

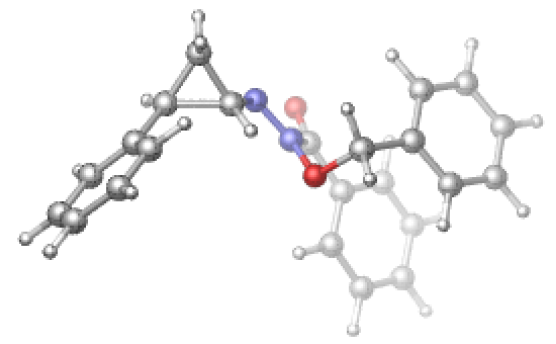
C
$\begin{array}{llll}-3.59844500 & 3.01223300 & -3.40364800\end{array}$
C
$\begin{array}{lll}-2.53807300 & 3.91031300 & -3.95867000\end{array}$
C
$\begin{array}{lll}-2.53239500 & 2.48165500 & -4.41478900\end{array}$
$\mathrm{H}$
$-4.57887400 \quad 3.12678000 \quad-3.84713700$
$\mathrm{H}$
$\begin{array}{lll}-1.73234300 & 4.22219600 & -3.30694900\end{array}$
$\mathrm{H}$
$-2.85422700 \quad 4.64754600 \quad-4.68506000$
$\mathrm{H}$
$\begin{array}{lll}-1.80258200 & 1.81922600 & -3.96970800\end{array}$
C
$\begin{array}{lll}-3.60033400 & 2.49660800 & -2.01600400\end{array}$
C
$\begin{array}{lll}-4.80608700 & 2.06758900 & -1.44900200\end{array}$
C
$\begin{array}{llll}-2.43598200 & 2.40040900 & -1.24370500\end{array}$
C
$\begin{array}{llll}-4.84968300 & 1.56255400 & -0.15478000\end{array}$
$\mathrm{H}$
$\begin{array}{lll}-5.71813600 & 2.13371100 & -2.03088100\end{array}$
C
$\begin{array}{lll}-2.47864200 & 1.89206300 & 0.04875500\end{array}$ 


\begin{tabular}{|c|c|c|c|}
\hline $\mathrm{H}$ & -1.48582000 & 2.72271700 & -1.65173300 \\
\hline $\mathrm{C}$ & -3.68521500 & 1.47107100 & 0.60114900 \\
\hline $\mathrm{H}$ & -5.79568200 & 1.23987400 & 0.26309700 \\
\hline $\mathrm{H}$ & -1.56550900 & 1.82708500 & 0.62816100 \\
\hline $\mathrm{H}$ & -3.71685800 & 1.07790800 & 1.60967300 \\
\hline $\mathrm{N}$ & -2.99538500 & 2.22942700 & -5.71330700 \\
\hline $\mathrm{N}$ & -2.79002100 & 1.01818500 & -6.20352300 \\
\hline $\mathrm{O}$ & -1.88233800 & 0.14170200 & -5.59926600 \\
\hline $\mathrm{C}$ & -0.49147700 & 0.45513600 & -5.95443600 \\
\hline $\mathrm{H}$ & -0.30017800 & 1.50605900 & -5.73391300 \\
\hline $\mathrm{H}$ & 0.06865300 & -0.16371700 & -5.25445400 \\
\hline $\mathrm{C}$ & -3.29796600 & -0.79734300 & -7.82393600 \\
\hline $\mathrm{C}$ & -3.19157700 & -1.05034200 & -9.19302500 \\
\hline $\mathrm{C}$ & -3.39492500 & -1.86925300 & -6.93372600 \\
\hline $\mathrm{C}$ & -3.14524300 & -2.35479100 & -9.66390900 \\
\hline $\mathrm{H}$ & -3.12953000 & -0.21719300 & -9.87950700 \\
\hline $\mathrm{C}$ & -3.37144700 & -3.17341500 & -7.41013600 \\
\hline $\mathrm{H}$ & -3.49433500 & -1.68683700 & -5.87362600 \\
\hline $\mathrm{C}$ & -3.23482900 & -3.42008500 & -8.77331300 \\
\hline $\mathrm{H}$ & -3.03723900 & -2.53985900 & -10.72528600 \\
\hline $\mathrm{H}$ & -3.45799400 & -3.99904600 & -6.71470900 \\
\hline $\mathrm{H}$ & -3.20304100 & -4.43878800 & -9.13971400 \\
\hline $\mathrm{C}$ & -3.41006100 & 0.63068500 & -7.40779000 \\
\hline $\mathrm{O}$ & -4.03979500 & 1.44551000 & -8.05503400 \\
\hline
\end{tabular}




$$
\begin{array}{llll}
\text { C } & -0.16051700 & 0.12872900 & -7.37760700 \\
\text { C } & -0.23395600 & 1.11433000 & -8.36164600 \\
\text { C } & 0.17890500 & -1.17511900 & -7.74346800 \\
\text { C } & 0.02122600 & 0.80188500 & -9.69292900 \\
\text { H } & -0.50146100 & 2.12729100 & -8.08407900 \\
\text { C } & 0.43727900 & -1.48867100 & -9.07073700 \\
\text { H } & 0.22755800 & -1.94716200 & -6.98463400 \\
\text { C } & 0.35691100 & -0.49981700 & -10.04841700 \\
\text { H } & -0.04502700 & 1.57295100 & -10.45045500 \\
\text { H } & 0.69326000 & -2.50422200 & -9.34575700 \\
\text { H } & 0.55313900 & -0.74549500 & -11.08482100
\end{array}
$$

\section{B3LYP-D3/def2-TZVP-SMD(THF)}

$H F=-1149.4080799$

Zero-point correction=

Thermal correction to Energy=

Thermal correction to Enthalpy=

Thermal correction to Gibbs Free Energy=

Sum of electronic and zero-point Energies=

Sum of electronic and thermal Energies=

Sum of electronic and thermal Enthalpies=

Sum of electronic and thermal Free Energies=

M06-2X/def2-TZVP-SMD(MeCN)

$H F=-1148.8872642$

M06-2X/def2-TZVP

0.386602 (Hartree/Particle)

$$
0.409406
$$

0.410350

$$
\begin{aligned}
& 0.330591 \\
& -1149.021478 \\
& -1148.998674 \\
& -1148.997730
\end{aligned}
$$

$-1149.077489$ 
$H F=-1148.8491792$

Solvent correction $=-0.038085$

DLPNO-CCSD(T)/def2-TZVPP

$H F=-1146.87220780549$

TS-ring opening of 2-phenylcyclopropyl-amidyl-nitrenyl radical (" $\mathrm{R}=\mathrm{N}(\mathrm{OBn}) \mathrm{Bz}$ ")

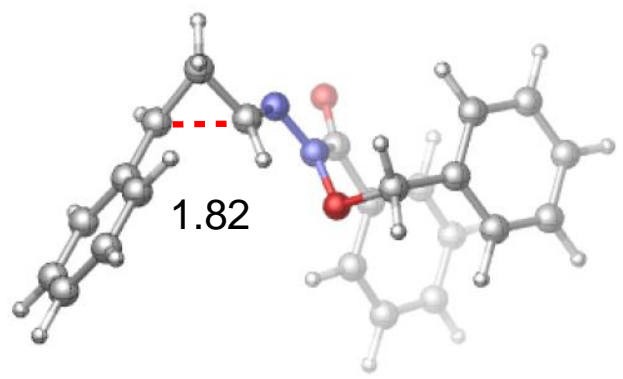

Imaginary Frequency $\left(\mathrm{cm}^{-1}\right)=-513.69$

$\begin{array}{llll}\text { C } & -3.71909600 & 3.13727000 & -3.34028300 \\ \text { C } & -2.68625600 & 3.99668200 & -3.96404200 \\ \text { C } & -2.44950300 & 2.64823400 & -4.54328600 \\ \text { H } & -4.67685700 & 3.10202300 & -3.84043900 \\ \text { H } & -1.90237200 & 4.38035200 & -3.32055000 \\ \text { H } & -3.05763500 & 4.73366600 & -4.66778400 \\ \text { H } & -1.78355400 & 1.97933100 & -4.01420100 \\ \text { C } & -3.63155900 & 2.51288900 & -2.03683600 \\ \text { C } & -4.73794200 & 1.79282500 & -1.54523000 \\ \text { C } & -2.47860400 & 2.57664100 & -1.23095400 \\ \text { C } & -4.69609800 & 1.17311700 & -0.30634800 \\ \text { H } & -5.63490700 & 1.72938300 & -2.15027300\end{array}$




\begin{tabular}{|c|c|c|c|}
\hline $\mathrm{C}$ & -2.44017500 & 1.94928200 & 0.00581300 \\
\hline $\mathrm{H}$ & -1.60613000 & 3.11743900 & -1.57505400 \\
\hline $\mathrm{C}$ & -3.54575200 & 1.24482800 & 0.47791300 \\
\hline $\mathrm{H}$ & -5.56258200 & 0.62961900 & 0.05066400 \\
\hline $\mathrm{H}$ & -1.54184300 & 2.01154700 & 0.60823900 \\
\hline $\mathrm{H}$ & -3.51174600 & 0.75861400 & 1.44474800 \\
\hline $\mathrm{N}$ & -2.90718500 & 2.37631800 & -5.77161700 \\
\hline $\mathrm{N}$ & -2.74225700 & 1.13555800 & -6.24781700 \\
\hline $\mathrm{O}$ & -1.89304000 & 0.23946800 & -5.59640100 \\
\hline $\mathrm{C}$ & -0.48228100 & 0.46871500 & -5.93362100 \\
\hline $\mathrm{H}$ & -0.23883400 & 1.51475400 & -5.74357400 \\
\hline $\mathrm{H}$ & 0.03292100 & -0.15479000 & -5.20382200 \\
\hline $\mathrm{C}$ & -3.31671600 & -0.69244500 & -7.81638500 \\
\hline $\mathrm{C}$ & -3.19421000 & -0.98388900 & -9.17592200 \\
\hline $\mathrm{C}$ & -3.48016800 & -1.73638200 & -6.90337500 \\
\hline $\mathrm{C}$ & -3.19713100 & -2.30063100 & -9.61446400 \\
\hline $\mathrm{H}$ & -3.08161900 & -0.17165200 & -9.88086100 \\
\hline $\mathrm{C}$ & -3.50641400 & -3.05205200 & -7.34746700 \\
\hline $\mathrm{H}$ & -3.59138800 & -1.52262200 & -5.85016900 \\
\hline $\mathrm{C}$ & -3.35327800 & -3.33856400 & -8.70104300 \\
\hline $\mathrm{H}$ & -3.07586200 & -2.51660700 & -10.66859100 \\
\hline $\mathrm{H}$ & -3.64426200 & -3.85542300 & -6.63438800 \\
\hline $\mathrm{H}$ & -3.36027500 & -4.36643000 & -9.04235800 \\
\hline $\mathrm{C}$ & -3.37431400 & 0.75042500 & -7.43266100 \\
\hline
\end{tabular}




\begin{tabular}{|c|c|c|c|c|}
\hline $\mathrm{O}$ & -3.97514000 & 1.56878800 & \multicolumn{2}{|c|}{-8.10641900} \\
\hline $\mathrm{C}$ & -0.14242400 & 0.08012100 & \multicolumn{2}{|c|}{-7.33903300} \\
\hline $\mathrm{C}$ & -0.14335000 & 1.03647000 & \multicolumn{2}{|c|}{-8.35416700} \\
\hline $\mathrm{C}$ & 0.13432000 & -1.25058500 & \multicolumn{2}{|c|}{-7.65776500} \\
\hline $\mathrm{C}$ & 0.12228200 & 0.66922100 & \multicolumn{2}{|c|}{-9.66939200} \\
\hline $\mathrm{H}$ & -0.36248000 & 2.07029300 & \multicolumn{2}{|c|}{-8.11387200} \\
\hline $\mathrm{C}$ & 0.40259500 & -1.61917000 & \multicolumn{2}{|c|}{-8.96884100} \\
\hline $\mathrm{H}$ & 0.12574800 & -1.99965600 & \multicolumn{2}{|c|}{-6.87480000} \\
\hline $\mathrm{C}$ & 0.39559200 & -0.65885000 & \multicolumn{2}{|c|}{-9.97770400} \\
\hline $\mathrm{H}$ & 0.11261300 & 1.41837700 & \multicolumn{2}{|c|}{-10.45139200} \\
\hline $\mathrm{H}$ & 0.60918100 & -2.65509000 & \multicolumn{2}{|c|}{-9.20701600} \\
\hline $\mathrm{H}$ & 0.59969200 & -0.94713500 & \multicolumn{2}{|c|}{-11.00154700} \\
\hline \multicolumn{5}{|c|}{ B3LYP-D3/def2-TZVP-SMD(THF) } \\
\hline \multicolumn{5}{|c|}{$\mathrm{HF}=-1149.4038336$} \\
\hline & correction $=$ & & \multicolumn{2}{|c|}{0.385082 (Hartree/Particle) } \\
\hline & prrection to Ene & $\operatorname{rgy}=$ & \multicolumn{2}{|c|}{0.407715} \\
\hline & orrection to Ent & halpy= & \multicolumn{2}{|c|}{0.408660} \\
\hline \multicolumn{4}{|c|}{ Thermal correction to Gibbs Free Energy= } & 0.329244 \\
\hline \multicolumn{4}{|c|}{ Sum of electronic and zero-point Energies= } & -1149.018752 \\
\hline \multicolumn{4}{|c|}{ Sum of electronic and thermal Energies= } & -1148.996118 \\
\hline \multicolumn{4}{|c|}{ Sum of electronic and thermal Enthalpies= } & -1148.995174 \\
\hline \multicolumn{4}{|c|}{ Sum of electronic and thermal Free Energies= } & -1149.074590 \\
\hline \multicolumn{5}{|c|}{ M06-2X/def2-TZVP-SMD(MeCN) } \\
\hline
\end{tabular}


M06-2X/def2-TZVP

$H F=-1148.8386929$

Solvent correction $=-0.0389608$

DLPNO-CCSD(T)/def2-TZVPP

$H F=-1146.86475363606$

Ring-opened product of 2-phenylcyclopropyl-amidyl-nitrenyl radical (" $\mathrm{R}=\mathrm{N}(\mathrm{OBn}) \mathrm{Bz}$ ”)

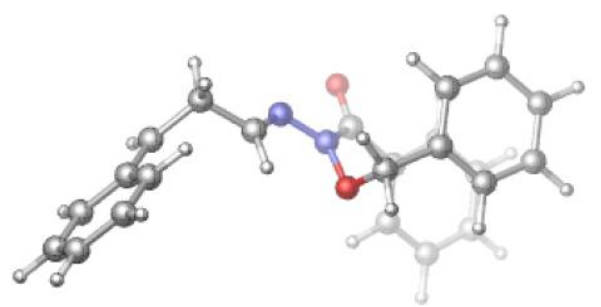

$\begin{array}{llll}\text { C } & -4.18662600 & 3.02074700 & -2.79380900\end{array}$

C $\quad-3.25029000 \quad 3.34911400 \quad-3.91566500$

C $\quad-2.85848600 \quad 2.08889900 \quad-4.63672600$

$\mathrm{H} \quad-5.23137900 \quad 2.90660000 \quad-3.06090600$

$\begin{array}{llll}\mathrm{H} & -2.34655300 & 3.84258700 & -3.54758500\end{array}$

$\mathrm{H} \quad-3.73353400 \quad 4.02304600 \quad-4.62528300$

$\begin{array}{llll}\mathrm{H} & -2.31559000 & 1.33711500 & -4.06778800\end{array}$

$\begin{array}{llll}\text { C } & -3.82232200 & 2.75944500 & -1.45786800\end{array}$

$\begin{array}{llll}\text { C } & -4.82654300 & 2.42292300 & -0.50591900\end{array}$

$\begin{array}{llll}\text { C } & -2.48018500 & 2.81063000 & -0.98908500\end{array}$

$\begin{array}{llll}\text { C } & -4.50980200 & 2.16337800 & 0.81219500\end{array}$

$\mathrm{H} \quad-5.85823900 \quad 2.37387500 \quad-0.83441100$

$\begin{array}{llll}\text { C } & -2.17644300 & 2.54716700 & 0.33393700\end{array}$ 


\begin{tabular}{|c|c|c|c|}
\hline $\mathrm{H}$ & -1.68005400 & 3.05547400 & -1.67479700 \\
\hline $\mathrm{C}$ & -3.18215800 & 2.22276700 & 1.24709300 \\
\hline $\mathrm{H}$ & -5.29631800 & 1.91140100 & 1.51342100 \\
\hline $\mathrm{H}$ & -1.14537300 & 2.59264400 & 0.66390100 \\
\hline $\mathrm{H}$ & -2.93602500 & 2.01846700 & 2.28134500 \\
\hline $\mathrm{N}$ & -3.21262900 & 1.91422700 & -5.84806400 \\
\hline $\mathrm{N}$ & -2.90404600 & 0.76291000 & -6.48996500 \\
\hline $\mathrm{O}$ & -2.15970800 & -0.21472100 & -5.83502400 \\
\hline $\mathrm{C}$ & -0.71654900 & 0.03652700 & -5.93666800 \\
\hline $\mathrm{H}$ & -0.50525100 & 1.04309100 & -5.57419900 \\
\hline $\mathrm{H}$ & -0.30516100 & -0.68692100 & -5.23367900 \\
\hline $\mathrm{C}$ & -3.25769000 & -0.83983900 & -8.33840200 \\
\hline $\mathrm{C}$ & -2.94933700 & -0.94538300 & -9.69508000 \\
\hline $\mathrm{C}$ & -3.52234800 & -1.99542900 & -7.60140900 \\
\hline $\mathrm{C}$ & -2.87126100 & -2.19155500 & -10.30111100 \\
\hline $\mathrm{H}$ & -2.75809500 & -0.04596600 & -10.26418900 \\
\hline $\mathrm{C}$ & -3.46812100 & -3.23971700 & -8.21618700 \\
\hline $\mathrm{H}$ & -3.77304300 & -1.92400200 & -6.55293500 \\
\hline $\mathrm{C}$ & -3.13118700 & -3.34196000 & -9.56287500 \\
\hline $\mathrm{H}$ & -2.60666400 & -2.26483100 & -11.34850700 \\
\hline $\mathrm{H}$ & -3.68599200 & -4.13146600 & -7.64158500 \\
\hline $\mathrm{H}$ & -3.07506000 & -4.31486100 & -10.03552300 \\
\hline $\mathrm{C}$ & -3.39226700 & 0.53921900 & -7.77531400 \\
\hline $\mathrm{O}$ & -3.92258200 & 1.43452400 & -8.40587900 \\
\hline
\end{tabular}




$$
\begin{array}{llll}
\text { C } & -0.18281800 & -0.16481300 & -7.32107400 \\
\text { C } & -0.04981000 & 0.91865200 & -8.18923700 \\
\text { C } & 0.14278500 & -1.44434400 & -7.77481300 \\
\text { C } & 0.39523500 & 0.72734900 & -9.49331000 \\
\text { H } & -0.30503200 & 1.91386900 & -7.84430200 \\
\text { C } & 0.59013400 & -1.63760000 & -9.07456600 \\
\text { H } & 0.03218400 & -2.29107400 & -7.10765200 \\
\text { C } & 0.71532900 & -0.55101400 & -9.93701300 \\
\text { H } & 0.48830400 & 1.57436300 & -10.16168700 \\
\text { H } & 0.83337500 & -2.63486400 & -9.41927600 \\
\text { H } & 1.05892800 & -0.70237500 & -10.95291300
\end{array}
$$

\section{B3LYP-D3/def2-TZVP-SMD(THF)}

$H F=-1149.4236393$

Zero-point correction $=$

Thermal correction to Energy=

Thermal correction to Enthalpy=

Thermal correction to Gibbs Free Energy=

Sum of electronic and zero-point Energies=

Sum of electronic and thermal Energies=

Sum of electronic and thermal Enthalpies=

Sum of electronic and thermal Free Energies=

M06-2X/def2-TZVP-SMD(MeCN)

$H F=-1148.8944504$

M06-2X/def2-TZVP
0.385428 (Hartree/Particle)

$$
0.408776
$$

0.409720

$$
0.327619
$$

$-1149.038211$

$-1149.014863$

$-1149.013919$

$-1149.096021$ 
$H F=-1148.8565729$

Solvent correction $=-0.0378775$

DLPNO-CCSD(T)/def2-TZVPP

$H F=-1146.88645856263$

2-phenylcyclopropyl-diazenyl radical (“R = :N:")

\begin{tabular}{|c|c|c|c|}
\hline $\mathrm{C}$ & -3.66868400 & 3.00499200 & -3.41331700 \\
\hline $\mathrm{C}$ & -2.84365100 & 4.17504600 & -3.86967200 \\
\hline $\mathrm{C}$ & -2.53297300 & 2.81132700 & -4.40663900 \\
\hline $\mathrm{H}$ & -4.65025200 & 2.93628300 & -3.86806300 \\
\hline $\mathrm{H}$ & -2.12881400 & 4.60579900 & -3.18114900 \\
\hline $\mathrm{H}$ & -3.31187600 & 4.86974500 & -4.55548700 \\
\hline $\mathrm{H}$ & -1.64501700 & 2.29276800 & -4.07981200 \\
\hline $\mathrm{C}$ & -3.58170900 & 2.43242000 & -2.04513600 \\
\hline $\mathrm{C}$ & -4.70762600 & 1.81347700 & -1.49447500 \\
\hline $\mathrm{C}$ & -2.40998200 & 2.48231300 & -1.28211300 \\
\hline $\mathrm{C}$ & -4.66779300 & 1.26229700 & -0.21840200 \\
\hline $\mathrm{H}$ & -5.62336700 & 1.76631100 & -2.07222300 \\
\hline $\mathrm{C}$ & -2.36859300 & 1.92862700 & -0.00838100 \\
\hline $\mathrm{H}$ & -1.52011400 & 2.95473600 & -1.68049600 \\
\hline
\end{tabular}




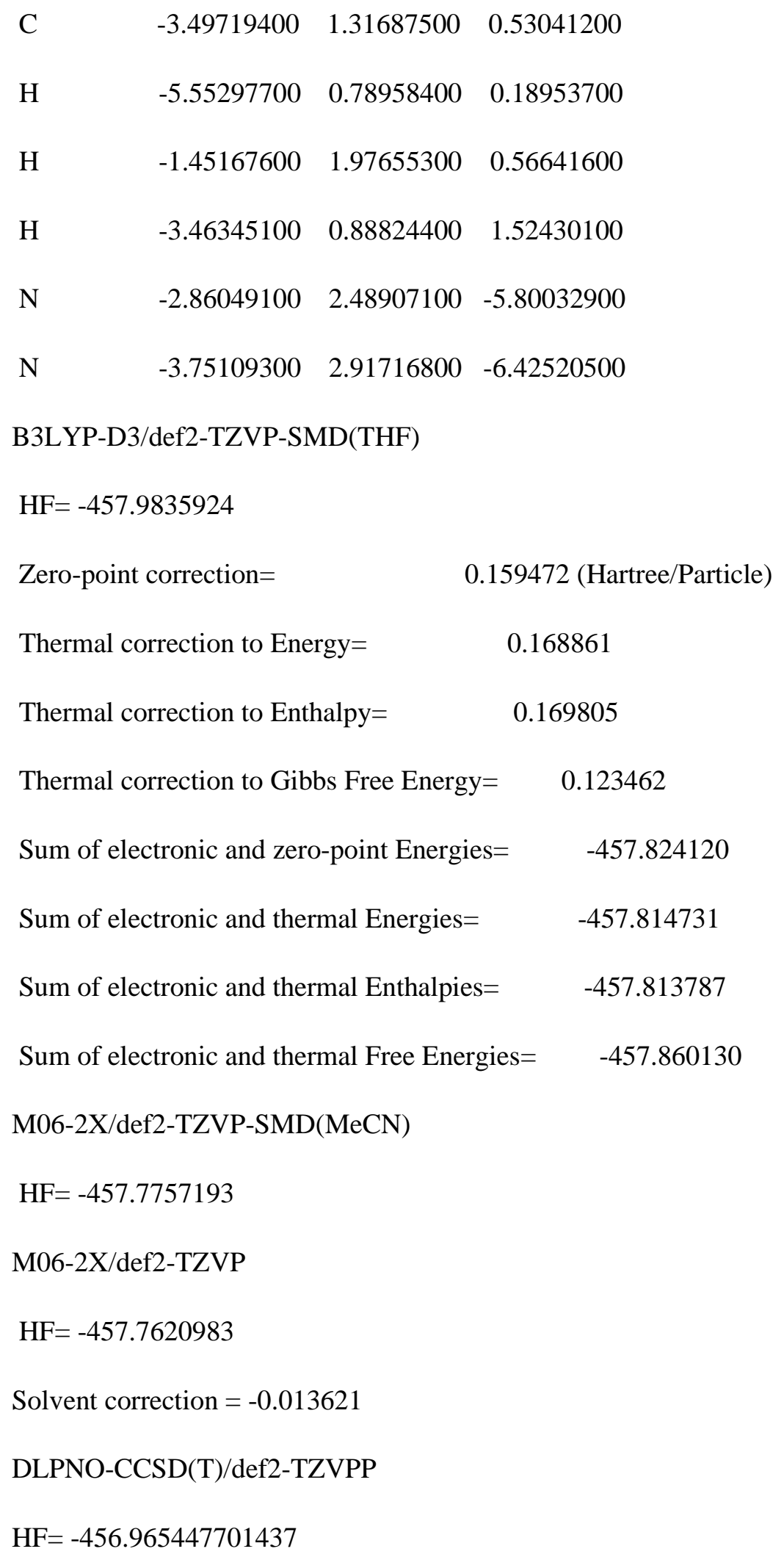


TS-ring opening of 2-phenylcyclopropyl-diazenyl radical (“'R = :N:")

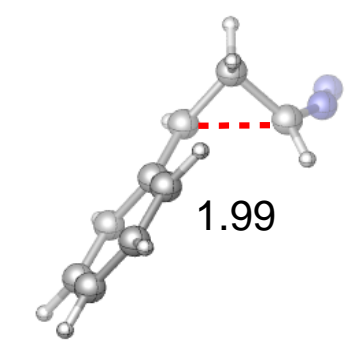

Imaginary Frequency $\left(\mathrm{cm}^{-1}\right)=-676.38$

$\begin{array}{llll}\text { C } & -3.83019300 & 3.24609500 & -3.20667100\end{array}$

C $\quad-2.80002000 \quad 4.03772900 \quad-3.89577700$

$\begin{array}{llll}\text { C } & -2.50235400 & 2.74407600 & -4.60727900\end{array}$

$\mathrm{H} \quad-4.79358000 \quad 3.17797400 \quad-3.69539300$

$\begin{array}{llll}\mathrm{H} & -1.97565300 & 4.41384700 & -3.29712500\end{array}$

$\mathrm{H} \quad-3.18066300 \quad 4.80668400 \quad-4.56268400$

$\mathrm{H} \quad-1.81701300 \quad 2.02351300 \quad-4.19029500$

$\begin{array}{llll}\text { C } & -3.67175000 & 2.57598500 & -1.94624700\end{array}$

C $\quad-4.74844700 \quad 1.82891400 \quad-1.41847400$

C $\quad-2.47880600 \quad 2.62233500 \quad-1.19256800$

$\begin{array}{lllll}\text { C } & -4.64182100 & 1.17712400 & -0.20195600\end{array}$

$\mathrm{H} \quad-5.67358200 \quad 1.77410500 \quad-1.98068400$

$\begin{array}{llll}\text { C } & -2.37745700 & 1.96024000 & 0.02170000\end{array}$

$\begin{array}{llll}\mathrm{H} & -1.62645800 & 3.17906500 & -1.56034600\end{array}$

$\begin{array}{llll}\text { C } & -3.45440700 & 1.23536700 & 0.52873400\end{array}$

$\begin{array}{llll}\mathrm{H} & -5.48618200 & 0.61670800 & 0.18128800\end{array}$

$\begin{array}{llll}\mathrm{H} & -1.45050500 & 2.01103500 & 0.58045200\end{array}$

$\begin{array}{llll}\mathrm{H} & -3.37036500 & 0.72294900 & 1.47876100\end{array}$ 


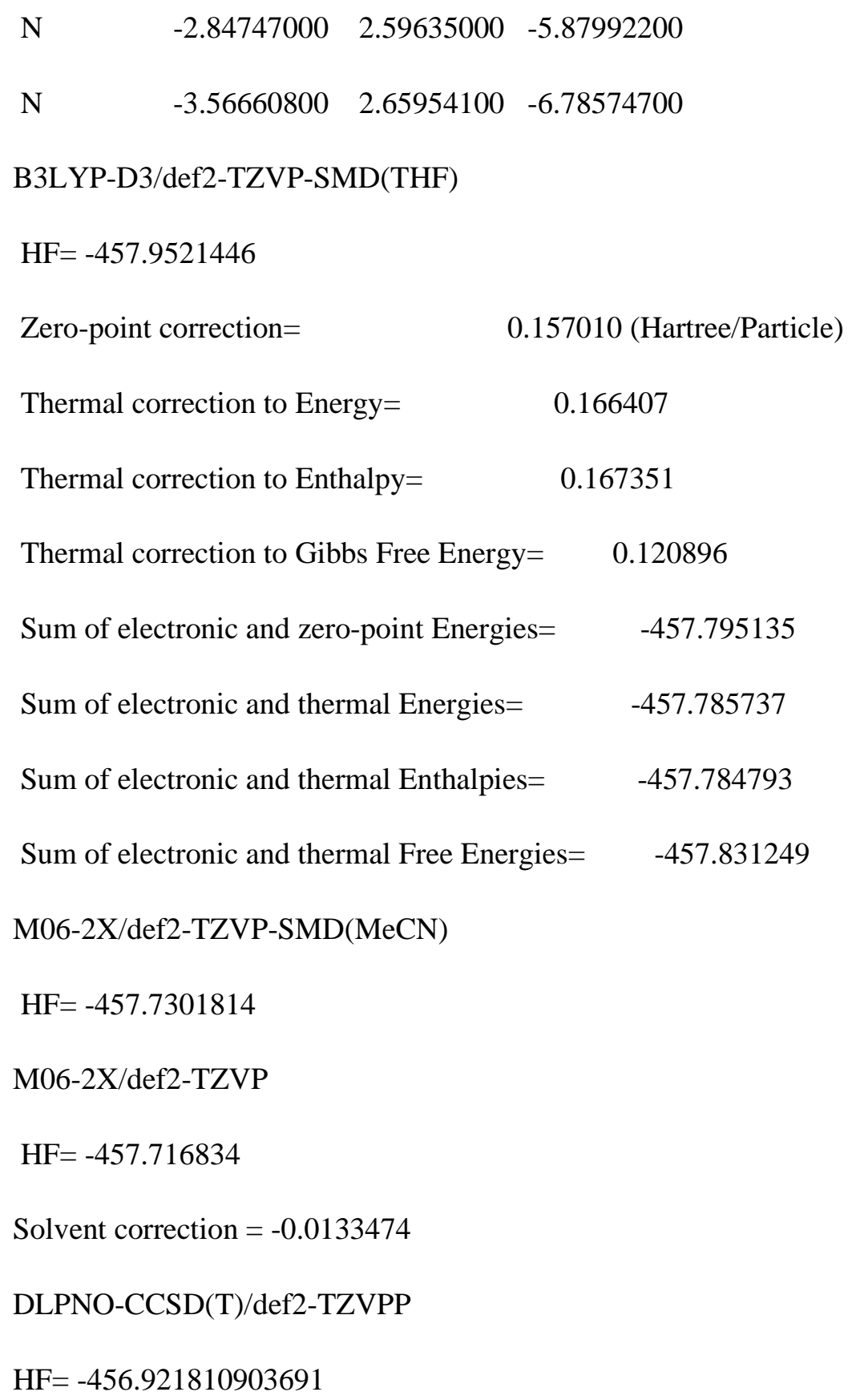


Ring-opened product of 2-phenylcyclopropyl-diazenyl radical (“ $R=: N$ :")

\begin{tabular}{|c|c|c|c|}
\hline $\mathrm{C}$ & -4.00619300 & 3.14632400 & -3.10958400 \\
\hline $\mathrm{C}$ & -2.96455300 & 3.82010200 & -3.94349500 \\
\hline $\mathrm{C}$ & -2.31501500 & 2.82905700 & -4.89351200 \\
\hline $\mathrm{H}$ & -4.99295000 & 3.05088600 & -3.54951000 \\
\hline $\mathrm{H}$ & -2.18797700 & 4.27869500 & -3.32779200 \\
\hline $\mathrm{H}$ & -3.41735900 & 4.62010600 & -4.53241200 \\
\hline $\mathrm{H}$ & -1.70696300 & 2.00457400 & -4.55070900 \\
\hline $\mathrm{C}$ & -3.78578000 & 2.52547300 & -1.86271800 \\
\hline $\mathrm{C}$ & -4.86273300 & 1.87643200 & -1.19542300 \\
\hline $\mathrm{C}$ & -2.51940600 & 2.50429600 & -1.21561600 \\
\hline $\mathrm{C}$ & -4.68528900 & 1.26171000 & 0.02790300 \\
\hline $\mathrm{H}$ & -5.83906800 & 1.87272500 & -1.66623300 \\
\hline $\mathrm{C}$ & -2.35437400 & 1.88262900 & 0.00869300 \\
\hline $\mathrm{H}$ & -1.66719900 & 2.97585100 & -1.68684000 \\
\hline $\mathrm{C}$ & -3.43000800 & 1.25813300 & 0.64382000 \\
\hline $\mathrm{H}$ & -5.52491700 & 0.77746800 & 0.51212500 \\
\hline $\mathrm{H}$ & -1.37776400 & 1.87982400 & 0.47808800 \\
\hline $\mathrm{H}$ & -3.29253000 & 0.77402200 & 1.60235500 \\
\hline $\mathrm{N}$ & -2.58503600 & 2.85451500 & -6.14949500 \\
\hline
\end{tabular}


B3LYP-D3/def2-TZVP-SMD(THF)

$H F=-457.9703202$

Zero-point correction=

0.157563 (Hartree/Particle)

Thermal correction to Energy=

0.167581

Thermal correction to Enthalpy=

0.168525

Thermal correction to Gibbs Free Energy=

0.119509

Sum of electronic and zero-point Energies= $-457.812757$

Sum of electronic and thermal Energies= $-457.802739$

Sum of electronic and thermal Enthalpies= $-457.801795$

Sum of electronic and thermal Free Energies= $-457.850811$

M06-2X/def2-TZVP-SMD(MeCN)

$H F=-457.7487695$

M06-2X/def2-TZVP

$H F=-457.7367756$

Solvent correction $=-0.0119939$

DLPNO-CCSD(T)/def2-TZVPP

$H F=-456.944352362053$ 
A

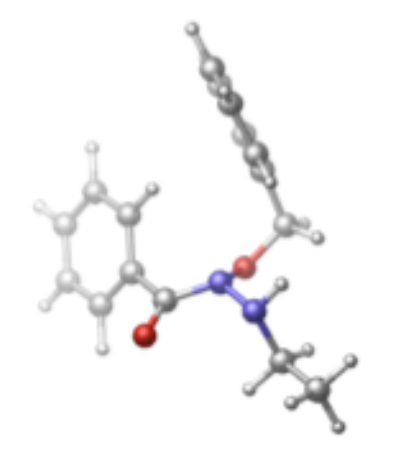

$\begin{array}{llll}\mathrm{N} & -0.89615700 & -0.91347400 & 0.07502200\end{array}$

O $\quad-0.23705500 \quad-0.54410200 \quad-1.15795000$

C $\quad \begin{array}{llll}1.10135100 & -1.07754600 & -1.21923200\end{array}$

$\mathrm{H} \quad 1.07202300 \quad-2.16382000 \quad-1.09541000$

$\begin{array}{llll}\mathrm{H} & 1.39811200 & -0.86662300 & -2.24674200\end{array}$

$\begin{array}{llll}\text { C } & -1.48031900 & 1.47234000 & 0.21731400\end{array}$

$\begin{array}{llll}\text { C } & -0.24791500 & 2.01287300 & 0.58101700\end{array}$

$\begin{array}{llll}\text { C } & -2.46704100 & 2.29917600 & -0.32016000\end{array}$

$\begin{array}{llll}\text { C } & -0.00368200 & 3.36866200 & 0.40175800\end{array}$

$\begin{array}{llll}\mathrm{H} & 0.51143900 & 1.37775700 & 1.01291600\end{array}$

C $\quad-2.21187800 \quad 3.65022500 \quad-0.52037300$

$\begin{array}{llll}\mathrm{H} & -3.42924800 & 1.87887200 & -0.58373100\end{array}$

$\begin{array}{llll}\text { C } & -0.98022100 & 4.18792200 & -0.15740400\end{array}$

$\begin{array}{llll}\mathrm{H} & 0.95189500 & 3.78389400 & 0.69693400\end{array}$

$\mathrm{H} \quad-2.97585400 \quad 4.28423200 \quad-0.95306700$

$\begin{array}{llll}\mathrm{H} & -0.78426300 & 5.24287300 & -0.30519400\end{array}$

$\begin{array}{llll}\text { C } & -1.82411800 & 0.04246300 & 0.48451400\end{array}$

$\begin{array}{llll}\mathrm{O} & -2.83745300 & -0.26382700 & 1.08470800\end{array}$ 


\begin{tabular}{|c|c|c|c|}
\hline $\mathrm{C}$ & 2.04609100 & -0.44705200 & -0.23852300 \\
\hline $\mathrm{C}$ & 2.18684200 & -0.97228000 & 1.04601800 \\
\hline $\mathrm{C}$ & 2.74473400 & 0.71250400 & -0.57605800 \\
\hline $\mathrm{C}$ & 2.99618600 & -0.34008700 & 1.98405100 \\
\hline $\mathrm{H}$ & 1.65326900 & -1.87608400 & 1.31585200 \\
\hline $\mathrm{C}$ & 3.56063600 & 1.34309100 & 0.35555800 \\
\hline $\mathrm{H}$ & 2.63489600 & 1.13018200 & -1.57006900 \\
\hline $\mathrm{C}$ & 3.68243300 & 0.82090100 & 1.64043400 \\
\hline $\mathrm{H}$ & 3.09111700 & -0.75191200 & 2.98125400 \\
\hline $\mathrm{H}$ & 4.09652600 & 2.24391000 & 0.08267800 \\
\hline $\mathrm{H}$ & 4.31304200 & 1.31436500 & 2.36976200 \\
\hline $\mathrm{N}$ & -1.24451300 & -2.23361200 & 0.19057500 \\
\hline $\mathrm{C}$ & -2.01103000 & -2.81148300 & -0.91962000 \\
\hline $\mathrm{H}$ & -2.92542100 & -2.22446600 & -1.02207100 \\
\hline $\mathrm{H}$ & -1.46198600 & -2.73940600 & -1.86490900 \\
\hline $\mathrm{H}$ & -0.42838400 & -2.78291500 & 0.43137400 \\
\hline $\mathrm{C}$ & -2.33705900 & -4.26132000 & -0.60668200 \\
\hline $\mathrm{H}$ & -2.92274800 & -4.34094400 & 0.31125300 \\
\hline $\mathrm{H}$ & -2.91020400 & -4.70447700 & -1.42296100 \\
\hline $\mathrm{H}$ & -1.42404400 & -4.85081100 & -0.48283700 \\
\hline
\end{tabular}

\section{B3LYP-D3/def2-TZVP-SMD(THF)}

$\mathrm{HF}=-880.8079388$

Zero-point correction $=\quad 0.313060($ Hartree/Particle $)$

Thermal correction to Energy $=\quad 0.331363$ 
Thermal correction to Enthalpy= $\quad 0.332307$

Thermal correction to Gibbs Free Energy $=\quad 0.263902$

Sum of electronic and zero-point Energies $=\quad-880.494878$

Sum of electronic and thermal Energies $=\quad-880.476576$

Sum of electronic and thermal Enthalpies $=\quad-880.475631$

Sum of electronic and thermal Free Energies $=\quad-880.544037$

M06-2X/def2-TZVP-SMD(MeCN)

$\mathrm{HF}=-880.3985567$

M06-2X/def2-TZVP

$\mathrm{HF}=-880.3682145$

Solvent correction $=-0.0303422$

DLPNO-CCSD(T)/def2-TZVPP

$H F=-878.89216646958$

Et• (R)

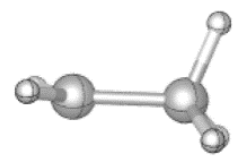

C $\quad-1.07385600 \quad 1.57514400 \quad-1.46630500$

$\mathrm{H} \quad-0.60248700 \quad 1.10735100 \quad-2.32152500$

$\mathrm{H} \quad-1.48280700 \quad 0.92777900 \quad-0.70074900$

C $\quad-1.31768800 \quad 3.03697500 \quad-1.43700400$

$\begin{array}{llll}\mathrm{H} & -0.53609100 & 3.59157400 & -1.96369600\end{array}$

$\mathrm{H} \quad-2.26824000 \quad 3.30151100 \quad-1.92809200$

$\mathrm{H} \quad-1.38389300 \quad 3.41926700 \quad-0.41464500$ 
B3LYP-D3/def2-TZVP-SMD(THF)

$\mathrm{HF}=-79.1947777$

Zero-point correction=

0.058878 (Hartree/Particle)

Thermal correction to Energy=

0.062841

Thermal correction to Enthalpy=

0.063785

Thermal correction to Gibbs Free Energy $=\quad 0.034706$

Sum of electronic and zero-point Energies=

$-79.135900$

Sum of electronic and thermal Energies=

$-79.131937$

Sum of electronic and thermal Enthalpies=

$-79.130993$

Sum of electronic and thermal Free Energies=

$-79.160072$

M06-2X/def2-TZVP-SMD(MeCN)

$H F=-79.1358794$

M06-2X/def2-TZVP

$\mathrm{HF}=-79.1345523$

Solvent correction $=-0.0013271$

DLPNO-CCSD(T)/def2-TZVPP

$\mathrm{HF}=-79.003548882879$

TS-A-B

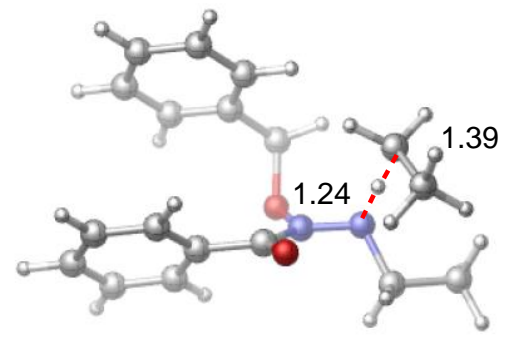

Imaginary Frequency $\left(\mathrm{cm}^{-1}\right)=-1849.58$

$\mathrm{N}$

$$
\begin{array}{lll}
-1.04717000 & -1.17990500 & -0.12718700
\end{array}
$$




\begin{tabular}{|c|c|c|c|}
\hline $\mathrm{O}$ & -0.50191600 & -0.73618800 & -1.34071900 \\
\hline $\mathrm{C}$ & 0.89414200 & -1.11234600 & -1.49646700 \\
\hline $\mathrm{H}$ & 1.00420600 & -2.17324800 & -1.26449500 \\
\hline $\mathrm{H}$ & 1.06051700 & -0.97274300 & -2.56506900 \\
\hline $\mathrm{C}$ & -0.90891800 & 1.13597200 & 0.72399000 \\
\hline $\mathrm{C}$ & -0.22247700 & 1.84183700 & 1.71218500 \\
\hline $\mathrm{C}$ & -1.42640100 & 1.81988200 & -0.37677400 \\
\hline $\mathrm{C}$ & -0.02719000 & 3.21050400 & 1.58749000 \\
\hline $\mathrm{H}$ & 0.16806600 & 1.30741400 & 2.56775900 \\
\hline $\mathrm{C}$ & -1.25082300 & 3.19324500 & -0.48740900 \\
\hline $\mathrm{H}$ & -1.96362700 & 1.28051600 & -1.14376900 \\
\hline $\mathrm{C}$ & -0.54240000 & 3.88977200 & 0.48779300 \\
\hline $\mathrm{H}$ & 0.52819900 & 3.74632200 & 2.34707100 \\
\hline $\mathrm{H}$ & -1.66397600 & 3.72000600 & -1.33873300 \\
\hline $\mathrm{H}$ & -0.39444900 & 4.95839600 & 0.39135300 \\
\hline $\mathrm{C}$ & -1.12876500 & -0.32440000 & 0.95110000 \\
\hline $\mathrm{O}$ & -1.41215100 & -0.76468100 & 2.05787500 \\
\hline $\mathrm{C}$ & 1.82719400 & -0.26068300 & -0.68482600 \\
\hline $\mathrm{C}$ & 2.47000300 & -0.77193600 & 0.44011800 \\
\hline $\mathrm{C}$ & 2.03608000 & 1.07568300 & -1.03456500 \\
\hline $\mathrm{C}$ & 3.29883300 & 0.03734300 & 1.21284900 \\
\hline $\mathrm{H}$ & 2.32276800 & -1.80931000 & 0.71173700 \\
\hline $\mathrm{C}$ & 2.86033500 & 1.88576800 & -0.26708600 \\
\hline $\mathrm{H}$ & 1.53442900 & 1.48374400 & -1.90379900 \\
\hline
\end{tabular}




\begin{tabular}{|c|c|c|c|}
\hline $\mathrm{C}$ & 3.49222600 & 1.36806300 & 0.86203700 \\
\hline $\mathrm{H}$ & 3.78919700 & -0.37198200 & 2.08759000 \\
\hline $\mathrm{H}$ & 3.00563900 & 2.92294200 & -0.54232700 \\
\hline $\mathrm{H}$ & 4.13172200 & 2.00174800 & 1.46421100 \\
\hline $\mathrm{N}$ & -1.31254800 & -2.51374700 & -0.09287700 \\
\hline $\mathrm{C}$ & -2.69908000 & -2.85249000 & 0.26743800 \\
\hline $\mathrm{H}$ & -2.89977100 & -2.65853500 & 1.32413100 \\
\hline $\mathrm{H}$ & -3.34949100 & -2.19459400 & -0.31562200 \\
\hline $\mathrm{H}$ & -0.58208100 & -3.05612600 & 0.74780900 \\
\hline $\mathrm{C}$ & -2.96618600 & -4.30758700 & -0.07809400 \\
\hline $\mathrm{H}$ & -2.28355000 & -4.97177700 & 0.45513600 \\
\hline $\mathrm{H}$ & -3.98568700 & -4.58008100 & 0.20337800 \\
\hline $\mathrm{H}$ & -2.84273500 & -4.48266300 & -1.14874300 \\
\hline $\mathrm{C}$ & 0.16407400 & -3.60560200 & 1.78165400 \\
\hline $\mathrm{H}$ & 0.66006300 & -4.42371900 & 1.25986400 \\
\hline $\mathrm{H}$ & 0.83415000 & -2.77853800 & 2.00166100 \\
\hline $\mathrm{C}$ & -0.74827200 & -3.99412000 & 2.90714000 \\
\hline $\mathrm{H}$ & -1.45484100 & -4.77359500 & 2.61521500 \\
\hline $\mathrm{H}$ & -0.17102400 & -4.38654300 & 3.75525700 \\
\hline $\mathrm{H}$ & -1.31027800 & -3.13101100 & 3.26650700 \\
\hline
\end{tabular}

\section{B3LYP-D3/def2-TZVP-SMD(THF)}

$\mathrm{HF}=-959.9963492$

Zero-point correction $=\quad 0.369918($ Hartree/Particle $)$

Thermal correction to Energy $=\quad 0.392077$ 
Thermal correction to Enthalpy= $\quad 0.393021$

Thermal correction to Gibbs Free Energy $=\quad 0.316444$

Sum of electronic and zero-point Energies $=\quad-959.626432$

Sum of electronic and thermal Energies $=\quad-959.604273$

Sum of electronic and thermal Enthalpies $=\quad-959.603328$

Sum of electronic and thermal Free Energies $=\quad-959.679905$

M06-2X/def2-TZVP-SMD(MeCN)

$\mathrm{HF}=-959.5227557$

M06-2X/def2-TZVP

$H F=-959.498089$

Solvent correction $=-0.0246667$

DLPNO-CCSD(T)/def2-TZVPP

$\mathrm{HF}=-957.888118934992$

\section{Et-H (P)}

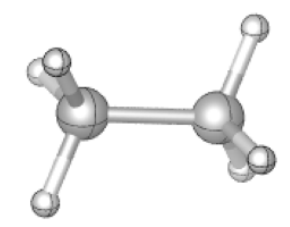
$\mathrm{H}$
$\begin{array}{lll}1.76133700 & -0.75279600 & 0.62902400\end{array}$
C
$2.35707400 \quad-0.96697200 \quad-0.26167900$
$\mathrm{C}$
$\begin{array}{lll}3.85069600 & -0.91697700 & 0.04427200\end{array}$
$\mathrm{H}$
$2.05924400-1.95227900 \quad-0.62832400$
$\mathrm{H} \quad 2.08256100 \quad-0.23471100-1.02505400$
H $\quad 4.12433700 \quad-1.64958600 \quad 0.80778500$ 


$$
\begin{array}{llll}
\mathrm{H} & 4.44603900 & -1.13117600 & -0.84691900 \\
\mathrm{H} & 4.14830900 & 0.06866000 & 0.41099300
\end{array}
$$

B3LYP-D3/def2-TZVP-SMD(THF)

$\mathrm{HF}=-79.867108$

Zero-point correction $=\quad 0.074186($ Hartree/Particle $)$

Thermal correction to Energy= $\quad 0.077662$

Thermal correction to Enthalpy= $\quad 0.078607$

Thermal correction to Gibbs Free Energy $=\quad 0.051083$

Sum of electronic and zero-point Energies $=\quad-79.792922$

Sum of electronic and thermal Energies $=\quad-79.789446$

Sum of electronic and thermal Enthalpies $=\quad-79.788501$

Sum of electronic and thermal Free Energies $=\quad-79.816025$

M06-2X/def2-TZVP-SMD(MeCN)

$\mathrm{HF}=-79.8058571$

M06-2X/def2-TZVP

$\mathrm{HF}=-79.8044115$

Solvent correction $=-0.0014456$

DLPNO-CCSD(T)/def2-TZVPP

$H F=-79.675365382172$

B

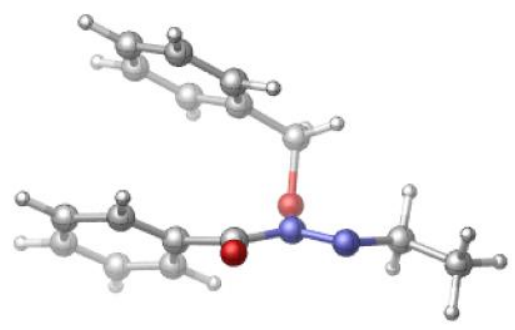




\begin{tabular}{|c|c|c|c|}
\hline $\mathrm{N}$ & -1.11223700 & -1.21260400 & -0.26084700 \\
\hline $\mathrm{O}$ & -0.51408600 & -0.73518000 & -1.43430800 \\
\hline $\mathrm{C}$ & 0.91077100 & -1.08221200 & -1.51112300 \\
\hline $\mathrm{H}$ & 1.02347600 & -2.15264000 & -1.34129200 \\
\hline $\mathrm{H}$ & 1.14447900 & -0.86033200 & -2.55174300 \\
\hline $\mathrm{C}$ & -0.93674100 & 1.09769600 & 0.65409100 \\
\hline $\mathrm{C}$ & -0.30936200 & 1.78678800 & 1.69392200 \\
\hline $\mathrm{C}$ & -1.38417400 & 1.80349700 & -0.46518600 \\
\hline $\mathrm{C}$ & -0.09874000 & 3.15510600 & 1.60179400 \\
\hline $\mathrm{H}$ & 0.02390800 & 1.23819800 & 2.56405700 \\
\hline $\mathrm{C}$ & -1.19189500 & 3.17631700 & -0.54435600 \\
\hline $\mathrm{H}$ & -1.88488400 & 1.28463200 & -1.26948400 \\
\hline $\mathrm{C}$ & -0.53932100 & 3.85352700 & 0.48191800 \\
\hline $\mathrm{H}$ & 0.41114800 & 3.67576600 & 2.40255900 \\
\hline $\mathrm{H}$ & -1.55032100 & 3.71819700 & -1.41074700 \\
\hline $\mathrm{H}$ & -0.37829200 & 4.92215000 & 0.41011400 \\
\hline $\mathrm{C}$ & -1.18991600 & -0.35674300 & 0.86188200 \\
\hline $\mathrm{O}$ & -1.49177000 & -0.81458700 & 1.94622600 \\
\hline $\mathrm{C}$ & 1.76694900 & -0.29339400 & -0.56865500 \\
\hline $\mathrm{C}$ & 2.13739900 & -0.83001100 & 0.66398400 \\
\hline $\mathrm{C}$ & 2.17216500 & 1.00162800 & -0.89718700 \\
\hline $\mathrm{C}$ & 2.89630400 & -0.08279200 & 1.55914000 \\
\hline $\mathrm{H}$ & 1.82291100 & -1.83339800 & 0.92623400 \\
\hline $\mathrm{C}$ & 2.93133800 & 1.74835000 & -0.00697700 \\
\hline
\end{tabular}




\begin{tabular}{|c|c|c|c|c|}
\hline $\mathrm{H}$ & 1.87947300 & 1.42663200 & \multicolumn{2}{|c|}{-1.84998800} \\
\hline $\mathrm{C}$ & 3.29355000 & 1.20684400 & \multicolumn{2}{|c|}{1.22433500} \\
\hline $\mathrm{H}$ & 3.17368000 & -0.50638200 & \multicolumn{2}{|c|}{2.51643000} \\
\hline $\mathrm{H}$ & 3.23504000 & 2.75446500 & \multicolumn{2}{|c|}{-0.26772300} \\
\hline $\mathrm{H}$ & 3.88173100 & 1.79139900 & \multicolumn{2}{|c|}{1.92099600} \\
\hline $\mathrm{N}$ & -1.58582300 & -2.43925500 & \multicolumn{2}{|c|}{-0.19476600} \\
\hline $\mathrm{C}$ & -1.66062700 & -3.15710200 & \multicolumn{2}{|c|}{-1.45471700} \\
\hline $\mathrm{H}$ & -2.18755300 & -2.54579800 & \multicolumn{2}{|c|}{-2.19751800} \\
\hline $\mathrm{H}$ & -0.66254400 & -3.34463900 & \multicolumn{2}{|c|}{-1.86626100} \\
\hline $\mathrm{C}$ & -2.38348700 & -4.47507300 & \multicolumn{2}{|c|}{-1.22912900} \\
\hline $\mathrm{H}$ & -3.39456600 & -4.30563600 & \multicolumn{2}{|c|}{-0.85386400} \\
\hline $\mathrm{H}$ & -2.45283700 & -5.03071000 & \multicolumn{2}{|c|}{-2.16647400} \\
\hline $\mathrm{H}$ & -1.84950900 & -5.09224600 & \multicolumn{2}{|c|}{-0.50362800} \\
\hline \multicolumn{5}{|c|}{ B3LYP-D3/def2-TZVP-SMD(THF) } \\
\hline \multicolumn{5}{|c|}{$H F=-880.1672858$} \\
\hline Zer & correction $=$ & & \multicolumn{2}{|c|}{0.299537 (Hartree/Particle) } \\
\hline Th & orrection to Ene & $\operatorname{rgy}=$ & \multicolumn{2}{|c|}{0.317626} \\
\hline Th & orrection to Entl & halpy= & \multicolumn{2}{|c|}{0.318571} \\
\hline \multicolumn{4}{|c|}{ Thermal correction to Gibbs Free Energy= } & 0.251566 \\
\hline \multicolumn{4}{|c|}{ Sum of electronic and zero-point Energies= } & -879.867749 \\
\hline \multicolumn{4}{|c|}{ Sum of electronic and thermal Energies= } & -879.849660 \\
\hline \multicolumn{4}{|c|}{ Sum of electronic and thermal Enthalpies= } & -879.848715 \\
\hline \multicolumn{4}{|c|}{ Sum of electronic and thermal Free Energies= } & -879.915720 \\
\hline
\end{tabular}


$\mathrm{HF}=-879.7586297$

M06-2X/def2-TZVP

$H F=-879.7297072$

Solvent correction $=-0.0289225$

DLPNO-CCSD(T)/def2-TZVPP

$\mathrm{HF}=-878.251131550902$

\section{TS-B-D}

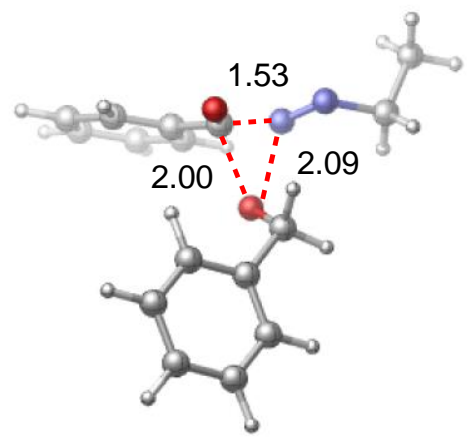
Imaginary Frequency $\left(\mathrm{cm}^{-1}\right)=-386.72$
$\mathrm{N}$
$\begin{array}{llll}0.58241500 & 0.28585700 & -0.21691800\end{array}$
$\mathrm{O}$
$2.47224600 \quad 1.10735100 \quad 0.15371800$
C
$\begin{array}{llll}3.38955300 & 0.10961900 & -0.16873000\end{array}$
$\mathrm{H}$
$3.54467300 \quad-0.56565700 \quad 0.68439200$
$\mathrm{H}$
$\begin{array}{lll}3.01222300 & -0.51439800 & -0.99971600\end{array}$
C
$\begin{array}{llll}0.64431400 & 2.67133700 & -0.96864500\end{array}$
C
$\begin{array}{lll}0.12941200 & 3.04872900 & 0.27248400\end{array}$
C
$\begin{array}{llll}0.77303100 & 3.62083100 & -1.98360500\end{array}$
C
$\begin{array}{lll}-0.25297000 & 4.36521900 & 0.49258200\end{array}$
$\mathrm{H}$
$\begin{array}{lll}0.03843400 & 2.31983800 & 1.06552400\end{array}$ 


\begin{tabular}{|c|c|c|c|}
\hline $\mathrm{C}$ & 0.39233200 & 4.93687400 & -1.75851300 \\
\hline $\mathrm{H}$ & 1.17103300 & 3.31856700 & -2.94294500 \\
\hline $\mathrm{C}$ & -0.12166500 & 5.31128300 & -0.52053800 \\
\hline $\mathrm{H}$ & -0.65049200 & 4.65485900 & 1.45717900 \\
\hline $\mathrm{H}$ & 0.49550100 & 5.66969500 & -2.54894400 \\
\hline $\mathrm{H}$ & -0.41976800 & 6.33758500 & -0.34510700 \\
\hline $\mathrm{C}$ & 1.07298400 & 1.28443600 & -1.26810800 \\
\hline $\mathrm{O}$ & 1.43140300 & 0.85944800 & -2.33759500 \\
\hline $\mathrm{C}$ & 4.71350800 & 0.71649000 & -0.58362400 \\
\hline $\mathrm{C}$ & 5.88776600 & 0.44136300 & 0.11410800 \\
\hline $\mathrm{C}$ & 4.76569100 & 1.58086300 & -1.67983500 \\
\hline $\mathrm{C}$ & 7.09780700 & 1.00792800 & -0.28080000 \\
\hline $\mathrm{H}$ & 5.85704900 & -0.22073900 & 0.97219200 \\
\hline $\mathrm{C}$ & 5.96980700 & 2.14916700 & -2.07491600 \\
\hline $\mathrm{H}$ & 3.85308100 & 1.80219900 & -2.21952900 \\
\hline $\mathrm{C}$ & 7.14159100 & 1.86363500 & -1.37582800 \\
\hline $\mathrm{H}$ & 8.00345300 & 0.78374300 & 0.27014300 \\
\hline $\mathrm{H}$ & 5.99744500 & 2.81549500 & -2.92891700 \\
\hline $\mathrm{H}$ & 8.08055400 & 2.30810500 & -1.68272700 \\
\hline $\mathrm{N}$ & 0.43882800 & -0.87717300 & -0.41979100 \\
\hline $\mathrm{C}$ & 0.29803100 & -1.86029300 & 0.67621700 \\
\hline $\mathrm{H}$ & 0.99755700 & -2.66243100 & 0.44066800 \\
\hline $\mathrm{H}$ & 0.59116500 & -1.38360900 & 1.61268200 \\
\hline C & -1.13140500 & -2.37793300 & 0.71121400 \\
\hline
\end{tabular}



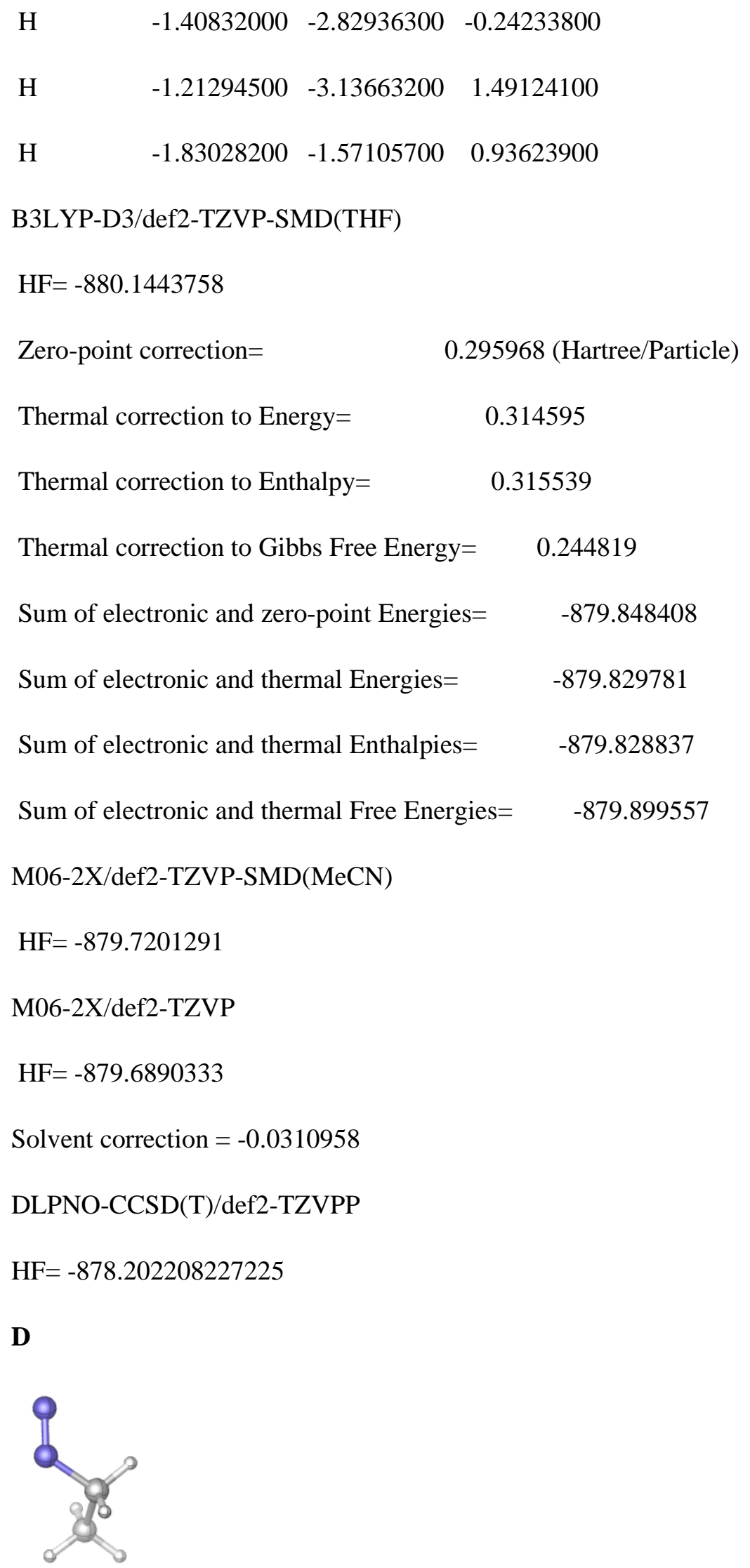


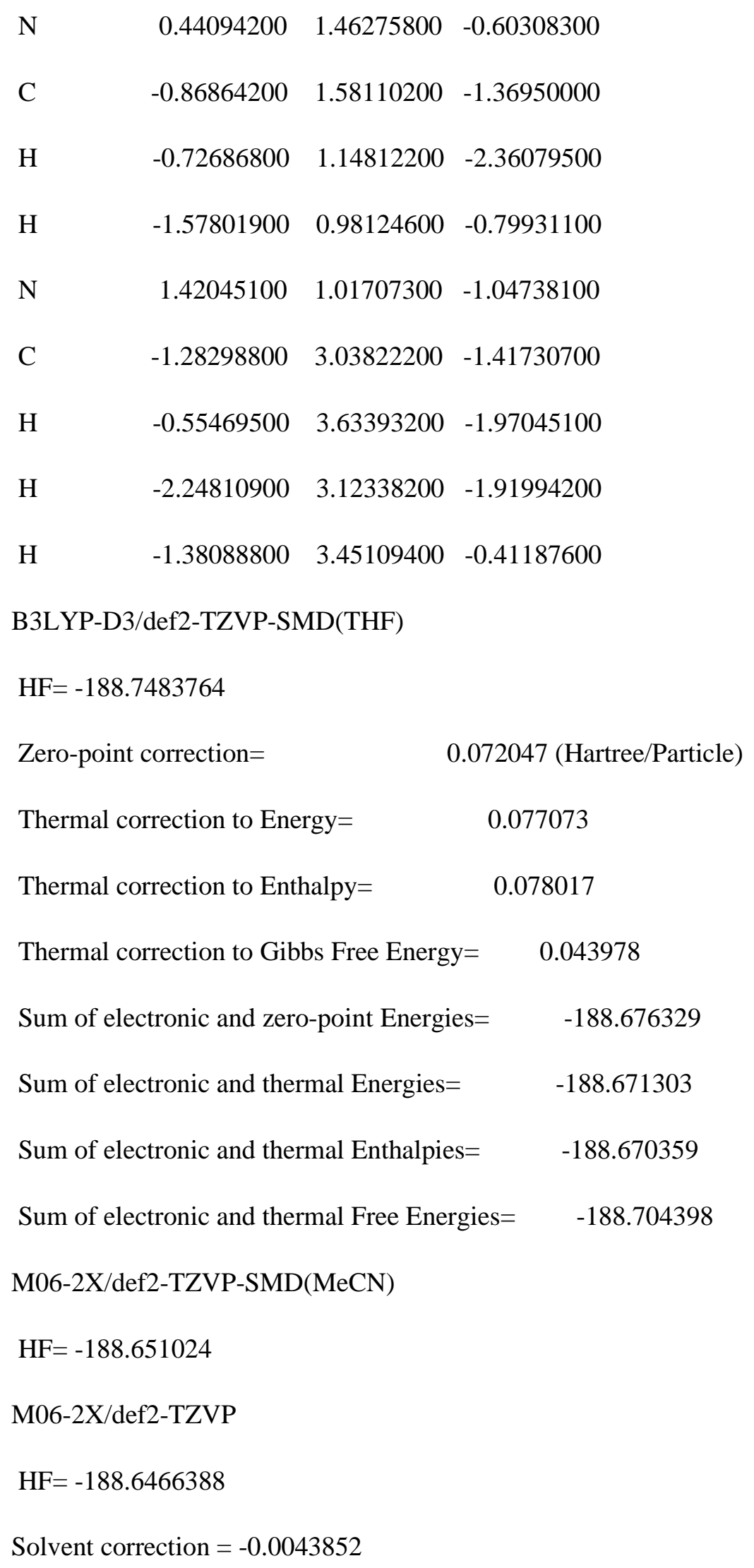




\section{DLPNO-CCSD(T)/def2-TZVPP}

$\mathrm{HF}=-188.349694557096$

\section{$\mathrm{PhCO}_{2} \mathrm{Bn}$}

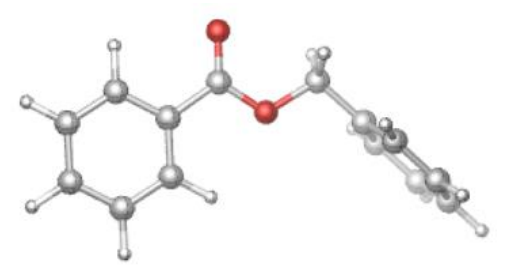
$\mathrm{O}$
$0.21945400 \quad 1.27161800 \quad 1.17243200$
C
$\begin{array}{lll}-0.79691600 & 1.46135500 & 2.19698700\end{array}$
$\mathrm{H}$
$\begin{array}{lll}-1.58231700 & 2.09978700 & 1.79124200\end{array}$
$\begin{array}{llll}\mathrm{H} & -1.23061000 & 0.49076900 & 2.43916900\end{array}$
$\begin{array}{llll}\text { C } & -0.13211300 & 2.08534900 & 3.38591100\end{array}$
$\begin{array}{llll}\text { C } & 0.41249300 & 1.28671000 & 4.39161300\end{array}$
$\begin{array}{llll}\text { C } & -0.02859300 & 3.47273200 & 3.48984400\end{array}$
$\begin{array}{llll}\text { C } & 1.05183400 & 1.86419900 & 5.48321000\end{array}$
$\mathrm{H}$
$\begin{array}{lll}0.33312900 & 0.20817700 & 4.31823600\end{array}$
C
$\begin{array}{lll}0.61047100 & 4.05322900 & 4.57971600\end{array}$
$\begin{array}{llll}\mathrm{H} & -0.45208600 & 4.09913100 & 2.71314900\end{array}$
C
$\begin{array}{lll}1.15232900 & 3.24905600 & 5.57831300\end{array}$
$\mathrm{H}$
$\begin{array}{lll}1.46872000 & 1.23477300 & 6.25981400\end{array}$
$\begin{array}{llll}\mathrm{H} & 0.68304500 & 5.13147800 & 4.65175300\end{array}$
$\begin{array}{llll}\mathrm{H} & 1.64752600 & 3.70030700 & 6.42935700\end{array}$
$\begin{array}{llll}\text { C } & -0.18876800 & 0.71988800 & 0.01889300\end{array}$
$\begin{array}{llll}\text { O } & -1.33510900 & 0.38465500 & -0.18729300\end{array}$ 


$$
\begin{array}{llll}
\text { C } & 0.91868800 & 0.56942700 & -0.96646100 \\
\text { C } & 2.22446700 & 0.98284400 & -0.68857300 \\
\text { C } & 0.62520200 & -0.00508600 & -2.20551600 \\
\text { C } & 3.22158400 & 0.82145900 & -1.64191400 \\
\text { H } & 2.45683400 & 1.42845800 & 0.26821200 \\
\text { C } & 1.62417300 & -0.16520600 & -3.15526300 \\
\text { H } & -0.38837000 & -0.32157400 & -2.41176900 \\
\text { C } & 2.92397300 & 0.24808400 & -2.87480700 \\
\text { H } & 4.23190900 & 1.14322200 & -1.42263600 \\
\text { H } & 1.39067000 & -0.61175600 & -4.11361700 \\
\text { H } & 3.70374100 & 0.12331100 & -3.61606900
\end{array}
$$

\section{B3LYP-D3/def2-TZVP-SMD(THF)}

$H F=-691.4844678$

Zero-point correction=

Thermal correction to Energy=

Thermal correction to Enthalpy=

Thermal correction to Gibbs Free Energy=

Sum of electronic and zero-point Energies=

Sum of electronic and thermal Energies=

Sum of electronic and thermal Enthalpies=

Sum of electronic and thermal Free Energies=

M06-2X/def2-TZVP-SMD(MeCN)

$\mathrm{HF}=-691.1718271$

M06-2X/def2-TZVP
0.224143 (Hartree/Particle)

$$
0.237325
$$

0.238270
0.180869

$-691.260324$

$-691.247142$

$-691.246198$

$-691.303599$ 
$H F=-691.1512885$

Solvent correction $=-0.0205386$

DLPNO-CCSD(T)/def2-TZVPP

$H F=-689.973614542717$

TS-A-C IP $^{-}$

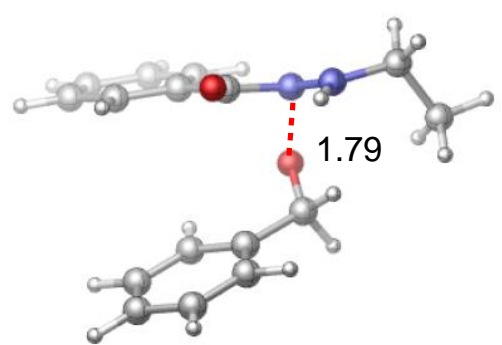

Imaginary Frequency $\left(\mathrm{cm}^{-1}\right)=-104.15$

$\mathrm{N}$

$\begin{array}{lll}1.12820200 & 0.50945300 & -0.69767600\end{array}$

$\mathrm{O}$

$2.60606100 \quad 1.46828600 \quad-0.36853700$

C

$\begin{array}{llll}3.65186400 & 1.07921200 & -1.19304900\end{array}$

$\mathrm{H}$

$\begin{array}{llll}4.56822800 & 1.10560800 & -0.58366400\end{array}$

$\mathrm{H}$

$3.55517300 \quad 0.02033800 \quad-1.49091900$

C

$\begin{array}{llll}0.23781600 & 2.69417000 & -1.43036100\end{array}$

C

$\begin{array}{llll}0.10205000 & 3.10231500 & -0.10077000\end{array}$

C

$\begin{array}{lll}-0.05297200 & 3.59117400 & -2.46179600\end{array}$

C

$\begin{array}{lll}-0.31828000 & 4.39309300 & 0.18874900\end{array}$

$\mathrm{H}$

$\begin{array}{lll}0.33234700 & 2.41128400 & 0.69628700\end{array}$

C

$\begin{array}{llll}-0.46546100 & 4.88242700 & -2.16889900\end{array}$

$\mathrm{H}$

$0.06420200 \quad 3.26991500 \quad-3.48774100$ 


\begin{tabular}{|c|c|c|c|}
\hline $\mathrm{C}$ & -0.59944600 & 5.28549700 & -0.84246200 \\
\hline $\mathrm{H}$ & -0.42366800 & 4.70548900 & 1.22012700 \\
\hline $\mathrm{H}$ & -0.67908900 & 5.57608400 & -2.97233100 \\
\hline $\mathrm{H}$ & -0.92180800 & 6.29374500 & -0.61286200 \\
\hline $\mathrm{C}$ & 0.66882100 & 1.32728100 & -1.79887300 \\
\hline $\mathrm{O}$ & 0.57917300 & 0.86843200 & -2.91743900 \\
\hline $\mathrm{C}$ & 3.84733700 & 1.92654900 & -2.43672000 \\
\hline $\mathrm{C}$ & 4.39048900 & 1.37064000 & -3.59474600 \\
\hline $\mathrm{C}$ & 3.50981500 & 3.27904800 & -2.43508600 \\
\hline $\mathrm{C}$ & 4.59321800 & 2.14832800 & -4.73027600 \\
\hline $\mathrm{H}$ & 4.64692400 & 0.31656200 & -3.61175000 \\
\hline $\mathrm{C}$ & 3.70576200 & 4.05928400 & -3.56947800 \\
\hline $\mathrm{H}$ & 3.07185400 & 3.71039500 & -1.54476400 \\
\hline $\mathrm{C}$ & 4.24896600 & 3.49706200 & -4.72135900 \\
\hline $\mathrm{H}$ & 5.00950300 & 1.70011500 & -5.62459900 \\
\hline $\mathrm{H}$ & 3.42941700 & 5.10686700 & -3.55572700 \\
\hline $\mathrm{H}$ & 4.39839400 & 4.10335100 & -5.60650400 \\
\hline $\mathrm{N}$ & 1.38633400 & -0.71091400 & -1.03886500 \\
\hline $\mathrm{C}$ & 1.52740000 & -1.73736900 & -0.01533500 \\
\hline $\mathrm{H}$ & 0.75428900 & -1.55058200 & 0.73139000 \\
\hline $\mathrm{H}$ & 1.30663100 & -2.69002200 & -0.50016200 \\
\hline $\mathrm{H}$ & 1.63538500 & -0.91414200 & -2.00364800 \\
\hline $\mathrm{C}$ & 2.90220300 & -1.77678900 & 0.64290000 \\
\hline $\mathrm{H}$ & 3.13271500 & -0.81766000 & 1.10745200 \\
\hline
\end{tabular}




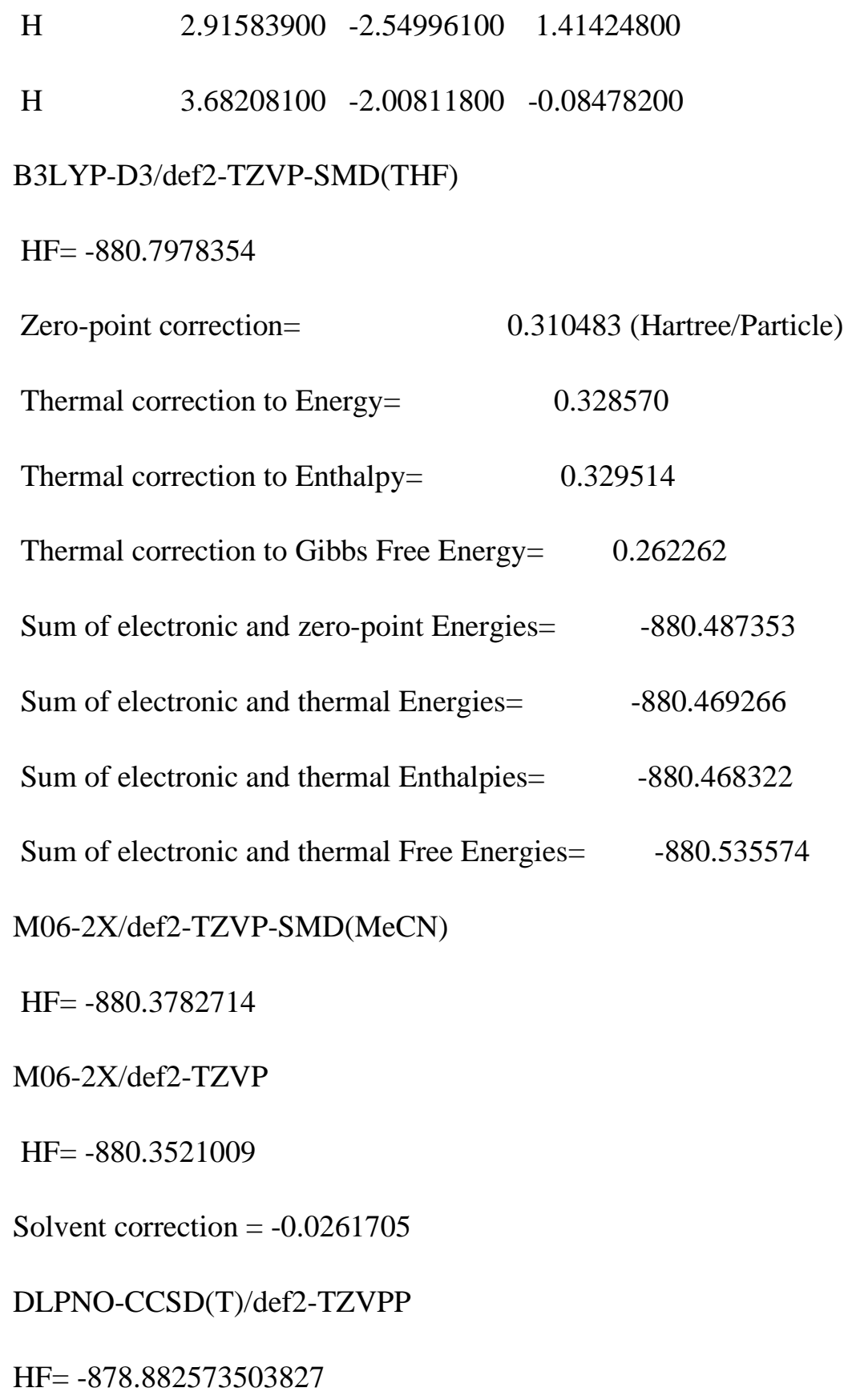




$$
\mathbf{C}^{\mathrm{IP}}
$$

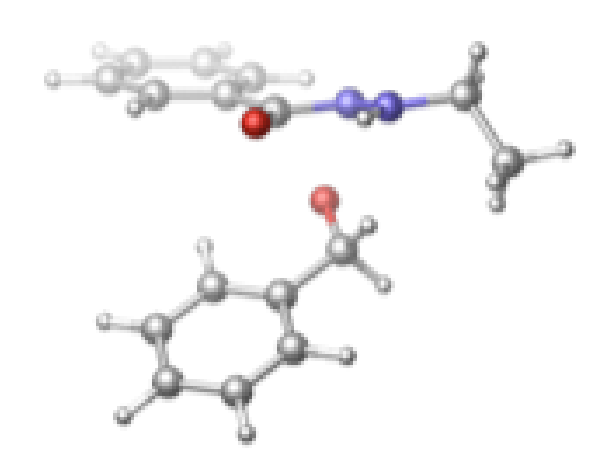
$\mathrm{N}$
$0.96541400 \quad 0.55281500 \quad-0.54061000$
$\begin{array}{llll}\mathrm{O} & 2.61424200 & 1.69640100 & -0.60287300\end{array}$
$\mathrm{C}$
$3.54780200 \quad 1.09972400 \quad-1.40316100$
$\mathrm{H}$
$\begin{array}{lll}4.45676200 & 0.86907000 & -0.82016000\end{array}$
$\begin{array}{llll}\mathrm{H} & 3.20144400 & 0.09625700 & -1.74191000\end{array}$
C
$\begin{array}{lll}0.11941400 & 2.77469900 & -1.22229400\end{array}$
$\mathrm{C}$
$0.01029800 \quad 3.14644300 \quad 0.12035100$
C
$-0.28881000 \quad 3.66295500 \quad-2.22056600$
$\mathrm{C}$
$\begin{array}{lll}-0.50360100 & 4.39177600 & 0.45542400\end{array}$
$\mathrm{H}$
$\begin{array}{lll}0.33945400 & 2.46689900 & 0.89231200\end{array}$
C
$\begin{array}{lll}-0.79864400 & 4.90809700 & -1.88158400\end{array}$
$\mathrm{H}$
$\begin{array}{llll}-0.19470400 & 3.36933200 & -3.25726800\end{array}$
C
$\begin{array}{lll}-0.90804700 & 5.27449300 & -0.54255800\end{array}$
$\begin{array}{llll}\mathrm{H} & -0.58461300 & 4.67696600 & 1.49689700\end{array}$
$\mathrm{H}$
$\begin{array}{llll}-1.10994700 & 5.59346800 & -2.65993000\end{array}$
$\mathrm{H}$
$\begin{array}{llll}-1.30625900 & 6.24621800 & -0.27738400\end{array}$
C
$\begin{array}{lll}0.65695200 & 1.46058600 & -1.63703800\end{array}$ 


\begin{tabular}{|c|c|c|c|}
\hline $\mathrm{O}$ & 0.70576600 & 1.06670100 & -2.78669500 \\
\hline $\mathrm{C}$ & 3.94599400 & 1.88760600 & -2.64277100 \\
\hline $\mathrm{C}$ & 4.82320700 & 1.32460500 & -3.57113400 \\
\hline $\mathrm{C}$ & 3.46660000 & 3.17457000 & -2.86691600 \\
\hline $\mathrm{C}$ & 5.20935100 & 2.03109500 & -4.70448600 \\
\hline $\mathrm{H}$ & 5.20387100 & 0.32153100 & -3.40652000 \\
\hline $\mathrm{C}$ & 3.84890000 & 3.88497800 & -4.00193600 \\
\hline $\mathrm{H}$ & 2.78303800 & 3.60988800 & -2.15086400 \\
\hline $\mathrm{C}$ & 4.72080600 & 3.31709500 & -4.92520300 \\
\hline $\mathrm{H}$ & 5.88785700 & 1.57858000 & -5.41806200 \\
\hline $\mathrm{H}$ & 3.46315200 & 4.88462800 & -4.16461500 \\
\hline $\mathrm{H}$ & 5.01743900 & 3.86898000 & -5.80888900 \\
\hline $\mathrm{N}$ & 1.19821800 & -0.62179800 & -0.94824400 \\
\hline $\mathrm{C}$ & 1.44231800 & -1.71026200 & -0.00351000 \\
\hline $\mathrm{H}$ & 0.77383400 & -1.55079800 & 0.84236700 \\
\hline $\mathrm{H}$ & 1.14872700 & -2.62896100 & -0.51177700 \\
\hline $\mathrm{H}$ & 1.24695700 & -0.78466900 & -1.95797400 \\
\hline $\mathrm{C}$ & 2.89151200 & -1.77930400 & 0.45981700 \\
\hline $\mathrm{H}$ & 3.18730400 & -0.84355600 & 0.93487400 \\
\hline $\mathrm{H}$ & 2.99677400 & -2.58618400 & 1.18736900 \\
\hline $\mathrm{H}$ & 3.56498900 & -1.97847500 & -0.37450600 \\
\hline
\end{tabular}

B3LYP-D3/def2-TZVP-SMD(THF)

$\mathrm{HF}=-880.7988499$

Zero-point correction $=\quad 0.310623($ Hartree/Particle $)$ 


$\begin{array}{ll}\text { Thermal correction to Energy= } & 0.329396 \\ \text { Thermal correction to Enthalpy= } & 0.330340 \\ \text { Thermal correction to Gibbs Free Energy= } & 0.260105 \\ \text { Sum of electronic and zero-point Energies= } & -880.488227 \\ \text { Sum of electronic and thermal Energies= } & -880.469454 \\ \text { Sum of electronic and thermal Enthalpies }= & -880.468510 \\ \text { Sum of electronic and thermal Free Energies }= & -880.538745 \\ \text { M06-2X/def2-TZVP-SMD(MeCN) } \\ \text { HF= -880.3769344 } \\ \text { M06-2X/def2-TZVP } \\ \text { HF= -880.346027 } \\ \text { Solvent correction }=-0.0309074 \\ \text { DLPNO-CCSD(T)/def2-TZVPP } \\ \text { HF= -878.87841594142 }\end{array}$

\section{TS-CIP-C}

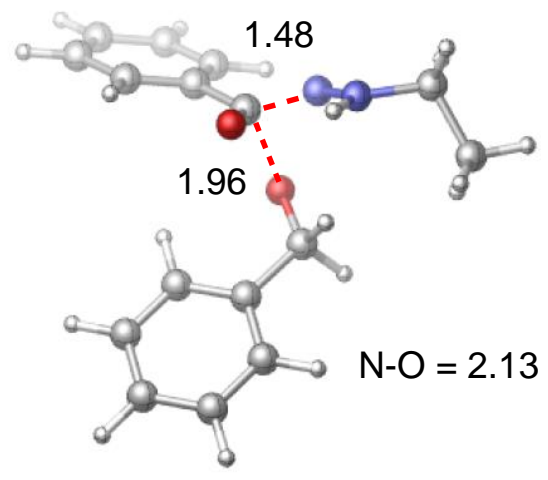

Imaginary Frequency $\left(\mathrm{cm}^{-1}\right)=-84.24$

N

$\begin{array}{llll}0.91893100 & 0.60674200 & -0.31723200\end{array}$ 


\begin{tabular}{|c|c|c|c|}
\hline $\mathrm{O}$ & 2.54010400 & 1.91854700 & -0.72945100 \\
\hline $\mathrm{C}$ & 3.49734300 & 1.24283600 & -1.44951100 \\
\hline $\mathrm{H}$ & 4.35268100 & 1.00118800 & -0.79844400 \\
\hline $\mathrm{H}$ & 3.12441600 & 0.25663600 & -1.79669500 \\
\hline $\mathrm{C}$ & 0.11447400 & 2.82456200 & -1.10850000 \\
\hline $\mathrm{C}$ & 0.05666000 & 3.29428800 & 0.20533100 \\
\hline $\mathrm{C}$ & -0.44216200 & 3.58538100 & -2.13697700 \\
\hline $\mathrm{C}$ & -0.55500800 & 4.51002300 & 0.48255400 \\
\hline $\mathrm{H}$ & 0.50166800 & 2.71564700 & 1.00169400 \\
\hline $\mathrm{C}$ & -1.05028400 & 4.80268000 & -1.85718800 \\
\hline $\mathrm{H}$ & -0.38926000 & 3.21463300 & -3.15175600 \\
\hline $\mathrm{C}$ & -1.10935100 & 5.26695500 & -0.54646900 \\
\hline $\mathrm{H}$ & -0.59538200 & 4.87065600 & 1.50297500 \\
\hline $\mathrm{H}$ & -1.47840500 & 5.38844900 & -2.66124800 \\
\hline $\mathrm{H}$ & -1.58443800 & 6.21534400 & -0.32713100 \\
\hline $\mathrm{C}$ & 0.76452500 & 1.53360800 & -1.46485100 \\
\hline $\mathrm{O}$ & 0.78489100 & 1.06702800 & -2.59931200 \\
\hline $\mathrm{C}$ & 4.00776400 & 1.97820100 & -2.67957800 \\
\hline $\mathrm{C}$ & 5.07550300 & 1.44787300 & -3.40604100 \\
\hline $\mathrm{C}$ & 3.43693900 & 3.17498900 & -3.10169500 \\
\hline $\mathrm{C}$ & 5.55968900 & 2.09743300 & -4.53568100 \\
\hline $\mathrm{H}$ & 5.53166000 & 0.51749000 & -3.08299400 \\
\hline $\mathrm{C}$ & 3.91915500 & 3.82858400 & -4.23296400 \\
\hline $\mathrm{H}$ & 2.61027900 & 3.58794200 & -2.54012400 \\
\hline
\end{tabular}




\begin{tabular}{|c|c|c|c|c|}
\hline $\mathrm{C}$ & 4.98093700 & 3.29344700 & \multicolumn{2}{|c|}{-4.95480400} \\
\hline $\mathrm{H}$ & 6.38872900 & 1.67219000 & \multicolumn{2}{|c|}{-5.08901900} \\
\hline $\mathrm{H}$ & 3.46287200 & 4.75904100 & \multicolumn{2}{|c|}{-4.55013500} \\
\hline $\mathrm{H}$ & 5.35663000 & 3.80243900 & \multicolumn{2}{|c|}{-5.83413600} \\
\hline $\mathrm{N}$ & 1.11581100 & -0.55793000 & \multicolumn{2}{|c|}{-0.71030800} \\
\hline $\mathrm{C}$ & 1.38989000 & -1.66426600 & \multicolumn{2}{|c|}{0.20298100} \\
\hline $\mathrm{H}$ & 1.12167900 & -1.32457200 & \multicolumn{2}{|c|}{1.20137500} \\
\hline $\mathrm{H}$ & 0.72624200 & -2.47988600 & \multicolumn{2}{|c|}{-0.08922600} \\
\hline $\mathrm{H}$ & 1.12206600 & -0.70915300 & \multicolumn{2}{|c|}{-1.73255500} \\
\hline $\mathrm{C}$ & 2.84801200 & -2.09618900 & \multicolumn{2}{|c|}{0.12566500} \\
\hline $\mathrm{H}$ & 3.50801100 & -1.28351800 & \multicolumn{2}{|c|}{0.43021800} \\
\hline $\mathrm{H}$ & 3.00468500 & -2.94302500 & \multicolumn{2}{|c|}{0.79554600} \\
\hline $\mathrm{H}$ & 3.11381400 & -2.40584700 & \multicolumn{2}{|c|}{-0.88633800} \\
\hline \multicolumn{5}{|c|}{ B3LYP-D3/def2-TZVP-SMD(THF) } \\
\hline \multicolumn{5}{|c|}{$H F=-880.7985251$} \\
\hline Zer & orrection $=$ & & \multicolumn{2}{|c|}{0.310302 (Hartree/Particle) } \\
\hline The & rection to Ene & $\operatorname{rgy}=$ & \multicolumn{2}{|c|}{0.328334} \\
\hline The & rection to Ent & halpy $=$ & \multicolumn{2}{|c|}{0.329278} \\
\hline \multicolumn{4}{|c|}{ Thermal correction to Gibbs Free Energy= } & 0.260770 \\
\hline \multicolumn{4}{|c|}{ Sum of electronic and zero-point Energies= } & -880.488223 \\
\hline \multicolumn{4}{|c|}{ Sum of electronic and thermal Energies= } & -880.470191 \\
\hline \multicolumn{4}{|c|}{ Sum of electronic and thermal Enthalpies= } & -880.469247 \\
\hline Sun & tronic and thes & mal Free Ener & gies $=$ & -880.537755 \\
\hline
\end{tabular}


$\mathrm{HF}=-880.380965$

M06-2X/def2-TZVP

$\mathrm{HF}=-880.3458138$

Solvent correction $=-0.0351512$

DLPNO-CCSD(T)/def2-TZVPP

$H F=-878.876062654733$

C

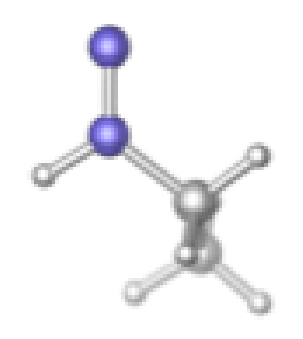

$\begin{array}{lllll}\mathrm{N} & 0.41994800 & 1.45087100 & -0.59958700\end{array}$

$\begin{array}{llll}\text { C } & -0.85573100 & 1.58974400 & -1.37130600\end{array}$

$\begin{array}{llll}\mathrm{H} & -0.66175100 & 1.16468600 & -2.35456700\end{array}$

$\begin{array}{llll}\mathrm{H} & -1.60484300 & 0.98776900 & -0.85045700\end{array}$

$\begin{array}{llll}\mathrm{N} & 1.48672000 & 1.07295600 & -1.01965400\end{array}$

$\begin{array}{llll}\text { C } & -1.27312300 & 3.04908800 & -1.43496300\end{array}$

$\mathrm{H} \quad-0.53302900 \quad 3.64024400 \quad-1.97807100$

$\mathrm{H} \quad-2.23241500 \quad 3.14118400 \quad-1.94666700$

$\begin{array}{llll}\mathrm{H} & -1.38659200 & 3.47004700 & -0.43267700\end{array}$

$\begin{array}{llll}\text { H } & 0.29044700 & 1.75049900 & 0.39361400\end{array}$

B3LYP-D3/def2-TZVP-SMD(THF)

$H F=-189.3332261$ 
Zero-point correction $=$

Thermal correction to Energy=

Thermal correction to Enthalpy=

Thermal correction to Gibbs Free Energy $=\quad 0.057105$

Sum of electronic and zero-point Energies $=\quad-189.248653$

Sum of electronic and thermal Energies $=\quad-189.243667$

Sum of electronic and thermal Enthalpies $=\quad-189.242722$

Sum of electronic and thermal Free Energies $=\quad-189.276121$

M06-2X/def2-TZVP-SMD(MeCN)

$\mathrm{HF}=-189.2346446$

M06-2X/def2-TZVP

$\mathrm{HF}=-189.2210547$

Solvent correction $=-0.0135899$

DLPNO-CCSD(T)/def2-TZVPP

$\mathrm{HF}=-188.923446963085$

\section{TS-C-D}

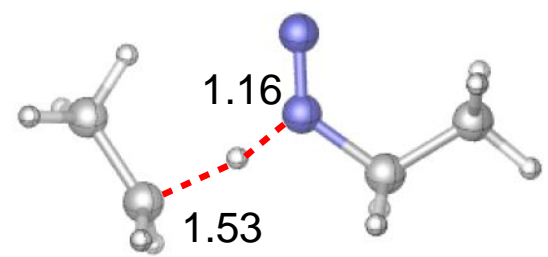

Imaginary Frequency $\left(\mathrm{cm}^{-1}\right)=-1335.76$

$\mathrm{N}$

$-0.94235500 \quad 2.48383200 \quad-6.03217600$

C

$-0.92696100 \quad 1.50320400 \quad-7.17775400$ 


\begin{tabular}{|c|c|c|c|}
\hline $\mathrm{H}$ & -0.06198400 & $0.86199100-6$. & 6.99026800 \\
\hline $\mathrm{H}$ & -1.82327900 & $0.89323700-7$. & 7.04182600 \\
\hline $\mathrm{N}$ & -0.93102100 & $3.66769400-6$. & 6.08816100 \\
\hline $\mathrm{C}$ & -0.98850500 & $1.37916900-3$. & 3.59080800 \\
\hline $\mathrm{H}$ & -1.80632500 & $0.66742600-3$ & 3.64834700 \\
\hline $\mathrm{H}$ & 0.00306700 & $0.93625800-3$. & 3.54741300 \\
\hline $\mathrm{C}$ & -0.87498800 & $2.17369900-8$ & 8.52860600 \\
\hline $\mathrm{H}$ & -0.85473300 & $1.40876300-9$. & 9.30714300 \\
\hline $\mathrm{H}$ & -1.74824200 & $2.80687700 \quad-8$ & 8.68971600 \\
\hline $\mathrm{H}$ & 0.01744900 & $2.79404400-8$. & 8.62752000 \\
\hline $\mathrm{C}$ & -1.21771400 & $2.67418800 \quad-2$. & 2.86937500 \\
\hline $\mathrm{H}$ & -2.22631700 & $2.73924600 \quad-2$ & 2.44979300 \\
\hline $\mathrm{H}$ & -0.49257500 & $2.82832900 \quad-2$ & 2.05641200 \\
\hline $\mathrm{H}$ & -1.09968100 & $3.55018400-3$ & 3.53943300 \\
\hline $\mathrm{H}$ & -0.97008500 & $1.91159400 \quad-5$. & 5.02742900 \\
\hline \multicolumn{4}{|c|}{ B3LYP-D3/def2-TZVP-SMD(THF) } \\
\hline \multicolumn{4}{|c|}{$H F=-268.5398848$} \\
\hline \multicolumn{3}{|c|}{ Zero-point correction $=$} & 41660 (Hartree/Particle) \\
\hline \multicolumn{3}{|c|}{ Thermal correction to Energy= } & 0.150775 \\
\hline \multicolumn{3}{|c|}{ Thermal correction to Enthalpy= } & 0.151719 \\
\hline \multicolumn{3}{|c|}{ Thermal correction to Gibbs Free Energy= } & 0.106574 \\
\hline \multicolumn{3}{|c|}{ Sum of electronic and zero-point Energies= } & -268.398225 \\
\hline \multicolumn{3}{|c|}{ Sum of electronic and thermal Energies= } & -268.389110 \\
\hline \multicolumn{3}{|c|}{ Sum of electronic and thermal Enthalpies= } & -268.388166 \\
\hline
\end{tabular}


Sum of electronic and thermal Free Energies $=\quad-268.433310$

M06-2X/def2-TZVP-SMD(MeCN)

$\mathrm{HF}=-268.3754524$

M06-2X/def2-TZVP

$\mathrm{HF}=-268.3674103$

Solvent correction $=-0.0080421$

DLPNO-CCSD(T)/def2-TZVPP

$\mathrm{HF}=-267.935224760696$

\section{TS-C-E}

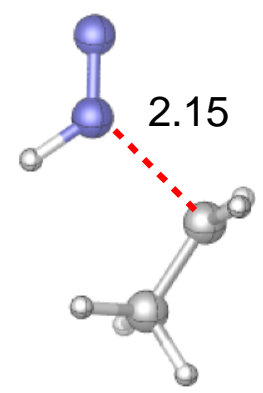

$\begin{array}{llll}\text { Imaginary Frequency }\left(\mathrm{cm}^{-1}\right)=-148.33 \\ \mathrm{~N} & 0.68025800 & 1.37109500 & -0.44050000 \\ \mathrm{C} & -1.07974900 & 1.59660700 & -1.64997100 \\ \mathrm{H} & -0.67289300 & 1.29797100 & -2.60836800 \\ \mathrm{H} & -1.70733400 & 0.85368400 & -1.17025400 \\ \mathrm{~N} & 1.47018700 & 0.52246600 & -0.38201800 \\ \mathrm{C} & -1.38895800 & 3.02781300 & -1.40995500 \\ \mathrm{H} & -0.78630300 & 3.68819800 & -2.03584500 \\ \mathrm{H} & -2.44513800 & 3.25935600 & -1.59179800\end{array}$




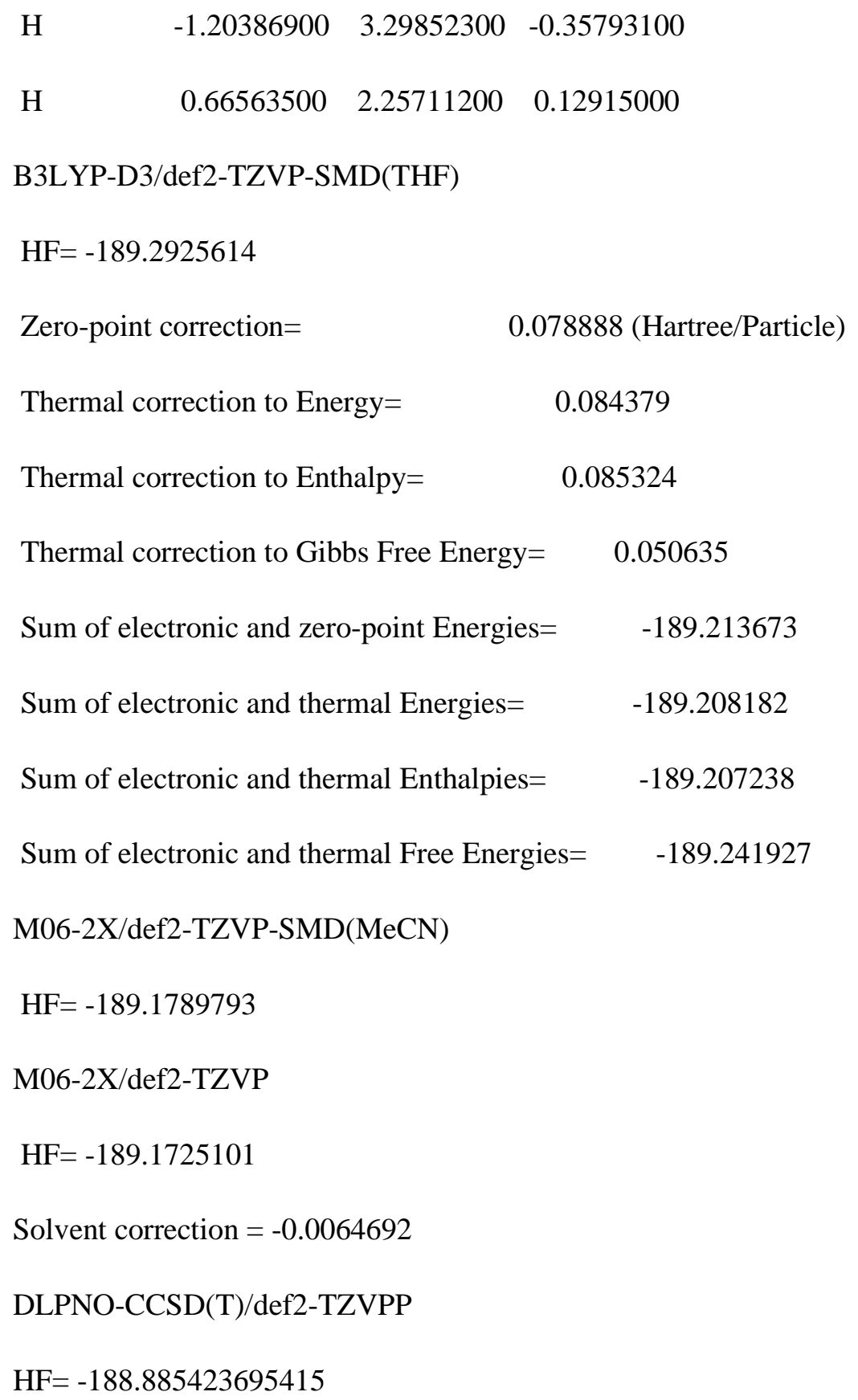




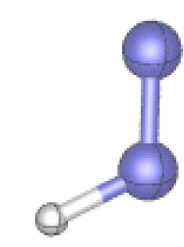

$$
\begin{aligned}
& \begin{array}{llll}
\mathrm{N} & 0.41328500 & 1.42652500 & -0.63376000
\end{array} \\
& \mathrm{~N} \quad \begin{array}{llll}
1.45016200 & 1.05873500 & -1.02581200
\end{array} \\
& \begin{array}{llll}
\mathrm{H} & 0.33345000 & 1.72796500 & 0.37409900
\end{array}
\end{aligned}
$$

\section{B3LYP-D3/def2-TZVP-SMD(THF)}

$H F=-110.0800465$

Zero-point correction $=$

Thermal correction to Energy=

Thermal correction to Enthalpy=

Thermal correction to Gibbs Free Energy $=\quad-0.008214$

Sum of electronic and zero-point Energies $=\quad-110.066614$

Sum of electronic and thermal Energies= $\quad-110.063757$

Sum of electronic and thermal Enthalpies $=\quad-110.062813$

Sum of electronic and thermal Free Energies $=\quad-110.088261$

M06-2X/def2-TZVP-SMD(MeCN)

$\mathrm{HF}=-110.0308222$

M06-2X/def2-TZVP

$H F=-110.028627$

Solvent correction $=-0.0021952$

DLPNO-CCSD(T)/def2-TZVPP

$H F=-109.868456278807$
0.013432 (Hartree/Particle)

0.016289

0.017233
$-110.088261$

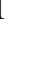




\section{TS-D-R}

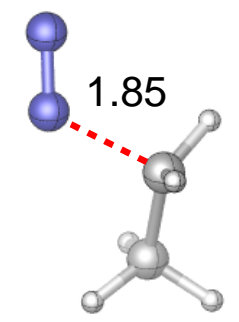

Imaginary Frequency $\left(\mathrm{cm}^{-1}\right)=-456.66$

$$
\mathrm{N}
$$

C $\quad-0.94811000 \quad 1.62382900 \quad-1.45038800$

$\begin{array}{llll}\mathrm{H} & -0.71649600 & 1.18799700 & -2.41750200\end{array}$

$\begin{array}{llll}\mathrm{H} & -1.51127700 & 0.95907000 & -0.80224700\end{array}$

$\begin{array}{llll}\mathrm{N} & 1.44008200 & 0.75152100 & -0.88470300\end{array}$

C $\quad-1.34719500 \quad 3.06168800 \quad-1.43561600$

$\mathrm{H} \quad-0.64858500 \quad 3.67646700 \quad-2.00675300$

$\begin{array}{llll}\mathrm{H} & -2.33851200 & 3.17849900 & -1.88688700\end{array}$

$\begin{array}{llll}\mathrm{H} & -1.39993600 & 3.44699900 & -0.41541100\end{array}$

B3LYP-D3/def2-TZVP-SMD(THF)

$\mathrm{HF}=-188.7424554$

Zero-point correction=

0.068828 (Hartree/Particle)

Thermal correction to Energy $=\quad 0.074175$

Thermal correction to Enthalpy $=\quad 0.075119$

Thermal correction to Gibbs Free Energy $=\quad 0.039354$

Sum of electronic and zero-point Energies $=\quad-188.673627$

Sum of electronic and thermal Energies $=\quad-188.668281$ 
Sum of electronic and thermal Enthalpies $=\quad-188.667336$

Sum of electronic and thermal Free Energies $=\quad-188.703101$

M06-2X/def2-TZVP-SMD(MeCN)

$\mathrm{HF}=-188.6414864$

M06-2X/def2-TZVP

$\mathrm{HF}=-188.6397774$

Solvent correction $=-0.001709$

DLPNO-CCSD(T)/def2-TZVPP

$\mathrm{HF}=-188.34500034258$

$\mathbf{N}_{2}$

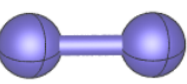

$\mathrm{N} \quad-1.04875300 \quad-1.33784100 \quad-0.48629400$

$\begin{array}{llll}\mathrm{N} & -0.89489500 & -0.77629400 & -1.40822400\end{array}$

B3LYP-D3/def2-TZVP-SMD(THF)

$\mathrm{HF}=-109.5679276$

Zero-point correction=

0.005596 (Hartree/Particle)

Thermal correction to Energy= $\quad 0.007957$

Thermal correction to Enthalpy $=\quad 0.008901$

Thermal correction to Gibbs Free Energy $=\quad-0.012827$

Sum of electronic and zero-point Energies $=\quad-109.562331$

Sum of electronic and thermal Energies $=\quad-109.559971$

Sum of electronic and thermal Enthalpies $=\quad-109.559027$ 
M06-2X/def2-TZVP-SMD(MeCN)

$H F=-109.530657$

M06-2X/def2-TZVP

$\mathrm{HF}=-109.5358514$

Solvent correction $=0.0051944$

DLPNO-CCSD(T)/def2-TZVPP

$\mathrm{HF}=-109.376069145198$ 